

Certain commercial entities, equipment, or materials may be identified in this document in order to describe an experimental procedure or concept adequately. Such identification is not intended to imply recommendation or endorsement by the National Institute of Standards and Technology, nor is it intended to imply that the entities, materials, or equipment are necessarily the best available for the purpose.

National Institute of Standards and Technology Special Publication 260-176

Supersedes NIST SP 260-176, 2017

106 pages (January 2018)

CODEN: NSPUE2 


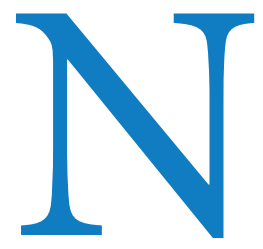

IST Standard Reference Materials ${ }^{\circledast}$ (SRMs) are used by industry, government, and academia to ensure the highest quality measurements. This catalog lists over 1200 individual reference materials produced and sold by NIST, each with carefully assigned values for chemical composition and physical properties.

SRMs find use in calibrating instruments and in assuring the long-term integrity of quality assurance programs. They are also key mechanisms for verifying important measurement results and in developing new measurement methods. SRMs provide users with tools to assist in establishing traceability of measurement results to the International System of Units (SI). Each SRM comes carefully packaged with documentation containing assigned values with stated uncertainties and a material safety data sheet, if applicable. Details on use, stability, and NIST analytical methods are also included.

For further information and prices, contact us at:

Telephone: (301) 975-2200

Fax: (301) 948-3730

E-mail: srminfo@nist.gov

www.nist.gov/srm

PLEASE NOTE: The tables are presented to facilitate comparisons among a family of materials to help customers select the best SRM for their needs. For specific values and uncertainties, the certificate is the only official source.

The data given in this catalog is constantly being revised. For the most up-to-date information, please consult our website at https://www.nist.gov/srm. 
This page is intentionally left blank.

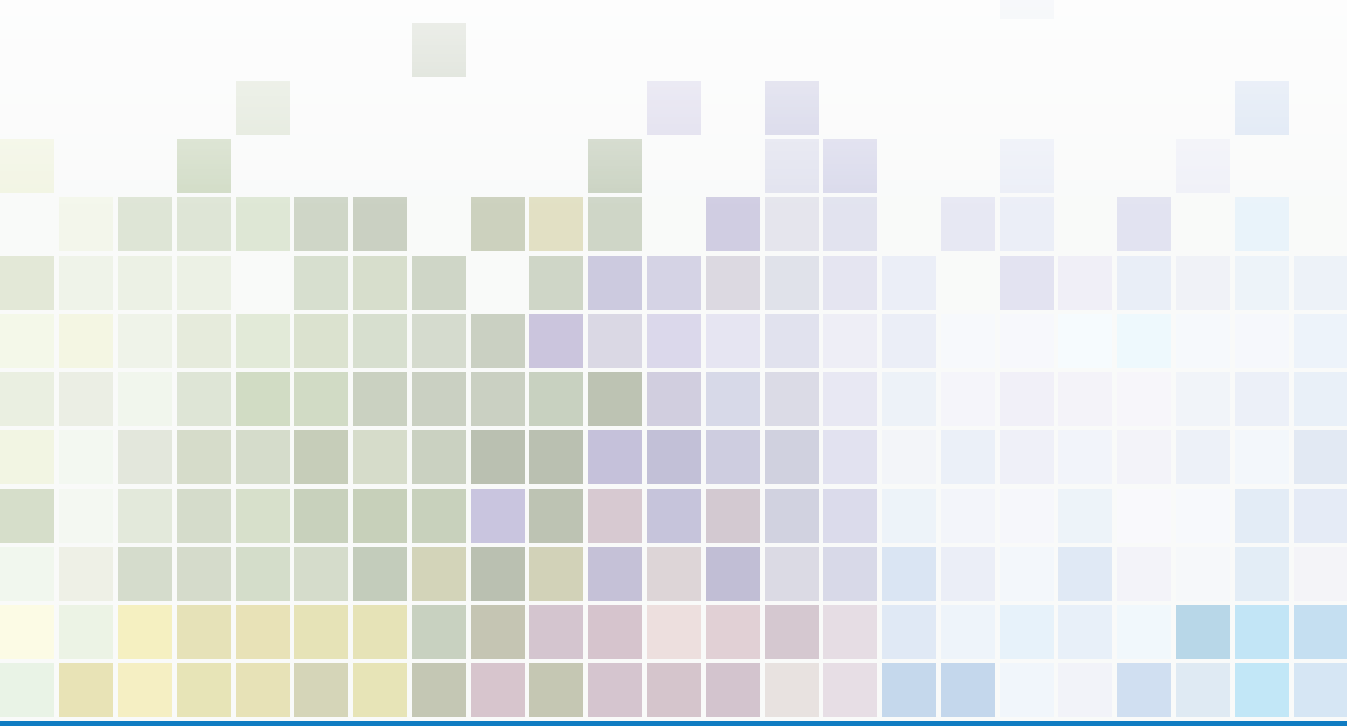




\section{Chemical Composition}

101. Ferrous Metals ................ 1

Plain Carbon Steels................................... 2

Low Alloy Steels ......................................... 2

Special Low Alloy Steels........................... 2

Low Alloy Steels .......................................... 3

High Alloy Steels........................................ 3

High Temperature Alloys ........................ 3

Stainless Steels (chip form)...................... 4

Stainless Steels (disk form) ...................... 4

Tool Steels ...................................................... 4

Specialty Steels ............................................ 4

Steelmaking Alloys ..................................... 4

Gases in Ferrous Metals ..........................5

Cast Steels, White Cast Irons, and Ductile Irons........................................ 5

Cast Irons................................................

102. Nonferrous Metals ........... 7

Aluminum Base Alloys ............................ 8

Cobalt Base Alloys ................................... 8

Copper Base Alloys ................................... 8

Copper Base Alloys ................................. 8

Copper "Benchmark" ...............................9

Lead Base Alloys ........................................9

Nickel Base Alloys .................................... 9

Tin Base Alloys ......................................... 10

Titanium Base Alloys ............................10

Zinc Base Alloys...................................... 10

Zirconium Base Alloys..........................10

103. Microanalysis...................11

Metals .......................................................... 12

Synthetic Glasses for

Microanalysis................................... 12

Semiconductor Thin Film for the Composition of Thin Films .......... 12

Nanomaterials: Composition ...............12

104. High-Purity Materials...... 13

High Purity Metals ................................ 14

Stoichiometry ......................................... 14

Microchemistry...................................... 14

Spectrometry, Single Element Standard Solutions...........................15

Anion Chromatography........................16

Stable Isotopic Materials .......................16

Light Stable Isotopic Materials...........17

105. Health \& Clinical

Industrial Hygiene ............19

Clinical Laboratory Materials ............20

Serum and Plasma Materials...............21
Ethanol Solutions ....................................21

Toxic Substances in Urine ...................21

Drugs of Abuse.......................................22

Biomaterials.............................................22

Respirable Materials on Filter Media ................................22

Respirable Materials ...............................22

DNA Profiling and Nucleic Acid Materials............................................23

Lead in Paint, Dust, and Soil................24

106. Inorganics......................25

Metal (Inorganics) Constituents in Natural Matrices .........................26

Mercury in Activated Carbon .............27

Environmental Matrices with Carbon Values .................................22

Used Auto Catalysts...............................27

Zeolites......................................................227

107. Primary Gas Mixtures.....29

Primary Gas Mixtures ............................30

108. Fossil \& Alternative Fuels..33

Alcohols and Ethers [Oxygenates] in Gasoline .........................................34

Metal Constituents in Fossil Fuels ....34

Sulfur, Mercury, and Chlorine in Fuels ..............................................34

Moisture in Oils and Alcohols ............35

Fossil Fuel: Trace Elements...................35

Biofuels .....................................................35

Biomass Feedstock .................................. 35

109. Organics .......................37

Organics ..................................................38

EPA: Organic Compounds Related to Water Analysis....................................39

Perfluorinated and Polyfluorinated Alkyl Substances (PFAS) ................39

Crime Scene Investigations ..................39

110. Food \& Agriculture.........41

Foods and Beverages .............................42

Food Contaminants and Allergens ...42

Agricultural Materials ...........................42

Fertilizers ................................................4 42

Wheat Hardness....................................... 43

Dietary Supplement Materials .............43

111. Geological Materials

\& Ores ..........................45

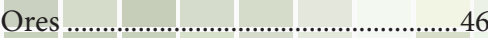

Ore Bioleaching Substrate ....................46

Clays .......................................................... 46

Rock and Minerals
Refractories............................................46

Soils, Sediments, and Sludges..............47

112. Ceramics \& Glasses.........49

Nitrides.................................................... 50

Cemented Carbides ...................................50

Glasses......................................................5 50

Trace Elements ..........................................50

113. Cement ..........................51

Cements and Related Materials ..........52

Portland Cement Clinkers (solid form) .....................................52

114. Engine Wear Materials .....53

Lubricating Oils ....................................54

115. Forensics........................55

Ethanol Solutions ....................................56

Drugs of Abuse.........................................56

DNA Profiling and Nucleic Acid Materials ..................................56

Crime Scene Investigations .................56

\section{Physical Properties}

201. Ion Activity.....................57

pH Calibration ..........................................

Biological Buffer Systems .....................58

pD Calibration ..........................................58

Ion-Selective Electrode Calibration ......58

202. Polymeric Properties .......59

Polymers....................................................60

Melt Flow Rate ..........................................60

Viscosity.................................................60

Biomaterials ..............................................60

203. Thermodynamic

Properties

Combustion Calorimetry .......................62

Solution Calorimetry ............................62

Differential Scanning Calorimetry and Differential Thermal Analysis .....62

Enthalpy and Temperature of Fusion...62

Enthalpy and Heat Capacity ...............62

Thermal Analysis Purity Set ...............62

Defining Fixed Point, International Temperature Scale of 1990, ITS-90

Reference Points

Freezing Point, Melting Point, and Triple Point Cells

Thermocouple Materials

Thermal Conductivity of Iron, Fibrous Glass, and Polystyrene ..................63

Thermal Expansion of Glass. .63 
Thermal Resistance Properties of Fibrous Glass and Fumed Silica Board 63

Thermoelectric Materials. .63

204. Optical Properties ..........65

Molecular Absorption ..........................66

Optical Properties .................................66

Fluorescence and Raman

Spectroscopy .66

Infrared Reflectance (solid form) ......66

Optical Rotation (powder form)........66

Photography (chart form) ...................66

205. Radioactivity .................66 67

Radiation Dosimetry.............................68

Radioactive Solutions ............................68

Radiopharmaceuticals ..........................69

Carbon-14 Dating..................................70

Radioactive Natural Matrix Materials. . .70

206. Electrical Properties .......71

Electrical Resistivity and Conductivity of Iron .72

Electrical Resistivity and Conductivity of Silicon ..........................................72

Superconducting Critical Current.....72

207. Metrology . .73

Scanning Electron Microscope (SEM) ........................74

Depth Profiling .........................................74

Optoelectronics.......................................74

Nonmagnetic Coating Thickness ......75

Microscale Dimensional Measurement Standards ...............75

208. Liquids \& Glasses............77

Chemical Resistance [Durability] of Glass ................................................. 78

Electrical Properties of Dielectrics ...78

Viscosity of Glass ...................................78

Glass Liquidus Temperature ...............78

Viscosity Fixpoints ..................................78

Relative Stress Optical Coefficient ....78

Density ......................................................78

209. X-Ray Diffraction ...........79

X-Ray Diffraction ...................................8 80

\section{Engineering Materials}

301. Sizing. .81

Particle Size

Cement and Coal Fly Ash Fineness .....83
Electrophoretic Mobility, E ..... . .83

Surface Area of Powders and Mercury Porosimetry Standards ....83

Particle Count Materials ........................83

302. Surface Finish ...............85

Microindentation Hardness .................86

Abrasive Wear .......................................... 86

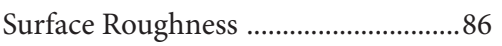

Rockwell Hardness .................................. 86

305. Fire Research ................8 87

Flooring Radiant Panel .........................8 88

Standard Cigarettes for Ignition Strength and Ignition Resistance Testing .............................................. 88

308. Nanomaterials ...............89

Nanomaterials .........................................90

309. Miscellaneous Performance Engineering Materials........91

Impact Standards: Charpy V-Notch and Izod Impact Specimens ........992

Tape Adhesion Testing .........................93

Bleached Kraft Pulps ............................93

Healthcare Equipment Standards .......93

Fracture Toughness of Ceramics .......93

Magnetic Moment ................................94

Standard Bullet and Cartridge Case ....94

Microelectromechanical Systems

(MEMS) ............................................94 


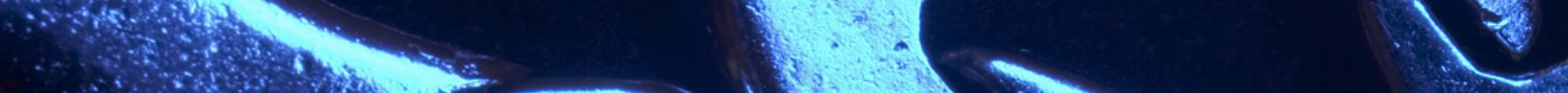


These SRMs are for checking optical emission and X-ray fluorescence spectrometric methods and for other methods of chemical analysis. They consist of steel alloys selected to provide a wide range of analytical values for elements. They are furnished as chips (small metal turnings), rods, disks, pins or powders from selected portions of commercial ingots. A "C" preceding the SRM number indicates a chill cast sample. Certificates are available on the website with information regarding specific alloy composition.

\section{Plain Carbon Steels (chip form)}

\begin{tabular}{|l|l|c|}
\hline SRM & Description & $\begin{array}{c}\text { Unit of } \\
\text { Issue }\end{array}$ \\
\hline $\mathbf{8 k}$ & Bessemer Steel (Simulated), 0.1 \% Carbon & $150 \mathrm{~g}$ \\
\hline $\mathbf{1 2 h}$ & Basic Open-Hearth Steel, 0.4\% Carbon & $150 \mathrm{~g}$ \\
\hline $\mathbf{1 3 g}$ & $0.6 \%$ Carbon Steel & $150 \mathrm{~g}$ \\
\hline $\mathbf{1 4 g}$ & Carbon Steel (AISI 1078) & $150 \mathrm{~g}$ \\
\hline $\mathbf{1 6 f}$ & $\begin{array}{l}\text { Basic Open-Hearth Steel, 1\% Carbon } \\
\text { (chip form) }\end{array}$ & $150 \mathrm{~g}$ \\
\hline $\mathbf{1 9 h}$ & Basic Electric Steel, 0.2\% Carbon & $150 \mathrm{~g}$ \\
\hline $\mathbf{2 0 g}$ & AISI 1045 Steel & $150 \mathrm{~g}$ \\
\hline $\mathbf{1 5 2 a}$ & $\begin{array}{l}\text { Basic Open-Hearth Steel 0.5\% Carbon } \\
\text { (Tin Bearing) }\end{array}$ & $150 \mathrm{~g}$ \\
\hline $\mathbf{1 7 8}$ & 0.4C Basic Oxygen Furnace Steel & $150 \mathrm{~g}$ \\
\hline $\mathbf{3 6 8}$ & Carbon Steel (AISI 1211) & $150 \mathrm{~g}$ \\
\hline
\end{tabular}

See Table 101.1 on the website for more information.

\section{Special Low Alloy Steels (chip and pin forms)}

\begin{tabular}{|l|l|c|}
\hline SRM & Description & $\begin{array}{c}\text { Unit of } \\
\text { Issue }\end{array}$ \\
\hline $\mathbf{3 6 1}$ & AISI 4340 Steel (chip form) & $150 \mathrm{~g}$ \\
\hline $\mathbf{3 6 3}$ & Chromium-Vanadium Steel (Modified) & $150 \mathrm{~g}$ \\
\hline $\mathbf{3 6 4}$ & LA Steel, High C (Modified) & $150 \mathrm{~g}$ \\
\hline $\mathbf{2 1 5 9}$ & Low-Alloy Steel (pin form) & $200 \mathrm{~g}$ \\
\hline $\mathbf{2 1 6 0}$ & Low-Alloy Steel (pin form) & $200 \mathrm{~g}$ \\
\hline $\mathbf{2 1 6 5}$ & Low Alloy Steel & $150 \mathrm{~g}$ \\
\hline $\mathbf{2 1 6 6}$ & Low Alloy Steel & $150 \mathrm{~g}$ \\
\hline $\mathbf{2 1 6 7}$ & Low Alloy Steel & $150 \mathrm{~g}$ \\
\hline $\mathbf{2 1 6 8}$ & High-Purity Iron (chip form) & $150 \mathrm{~g}$ \\
\hline
\end{tabular}

See Table 101.3 on the website for more information.

\section{Low Alloy Steels (chip form)}

\begin{tabular}{|l|l|c|}
\hline SRM & Description & $\begin{array}{c}\text { Unit of } \\
\text { Issue }\end{array}$ \\
\hline $\mathbf{3 0 f}$ & Cr-V Steel (SAE 6150) & $150 \mathrm{~g}$ \\
\hline $\mathbf{3 2 e}$ & $\begin{array}{l}\text { Carbon Low Alloy Steel (SAE 3140) } \\
\text { (chip form) }\end{array}$ & $50 \mathrm{~g}$ \\
\hline $\mathbf{3 3 e}$ & Nickel Steel & $150 \mathrm{~g}$ \\
\hline $\mathbf{3 6 b}$ & Chromium-Molybdenum Steel & $150 \mathrm{~g}$ \\
\hline $\mathbf{7 2 g}$ & Low Alloy Steel (AISI 4130) & $150 \mathrm{~g}$ \\
\hline $\mathbf{1 0 0 b}$ & Manganese Steel & $150 \mathrm{~g}$ \\
\hline $\mathbf{1 2 5 b}$ & LA Steel, High Silicon & $100 \mathrm{~g}$ \\
\hline $\mathbf{1 2 9 c}$ & LA Steel, High Sulfur (SAE 112) & $150 \mathrm{~g}$ \\
\hline $\mathbf{1 3 1 h}$ & Refined Cast Iron & $100 \mathrm{~g}$ \\
\hline $\mathbf{1 3 9 b}$ & Chromium-Nickel-Molybdenum Steel & $150 \mathrm{~g}$ \\
\hline $\mathbf{1 5 5}$ & Chromium-Tungsten Steel & $150 \mathrm{~g}$ \\
\hline $\mathbf{1 6 3}$ & Chromium Steel & $100 \mathrm{~g}$ \\
\hline $\mathbf{1 7 9}$ & LA Steel, High Silicon & $150 \mathrm{~g}$ \\
\hline $\mathbf{2 9 1}$ & Cr-Mo Steel (ASTM A-213) & $150 \mathrm{~g}$ \\
\hline $\mathbf{2 9 3}$ & Cr-Ni-Mo (AISI 8620) & $150 \mathrm{~g}$ \\
\hline $\mathbf{2 1 7 1}$ & LA Steel (HSLA 100) & $150 \mathrm{~g}$ \\
\hline
\end{tabular}

See Table 101.2 on the website for more information.

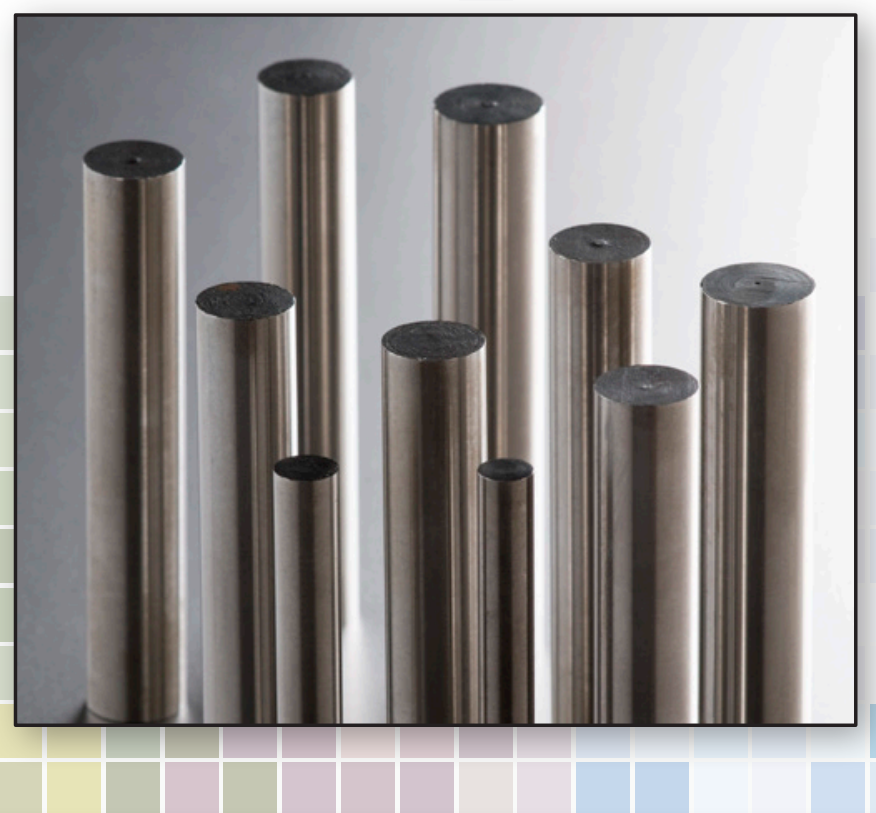




\section{Low Alloy Steels (disk and rod forms)}

\begin{tabular}{|c|c|c|}
\hline SRM & Description & $\begin{array}{l}\text { Unit of } \\
\text { Issue }\end{array}$ \\
\hline 663 & Chromium-Vanadium Steel (Modified) & 5 rods \\
\hline 665 & Electrolytic Iron & 5 rods \\
\hline 1134 & LA Steel, High Silicon & disk \\
\hline 1135 & LA Steel, High Silicon & disk \\
\hline 1218 & LA Steel, High Silicon & disk \\
\hline 1224 & LA Steel, Carbon (AISI 1078) & disk \\
\hline 1225 & LA Steel (AISI 4130) & disk \\
\hline 1226 & LA Steel & disk \\
\hline 1227 & LA Steel, Basic Open Hearth, $1 \%$ C & disk \\
\hline 1228 & LA Steel, $0.1 \%$ C & disk \\
\hline $1264 a$ & LA Steel, High Carbon (Modified) & disk \\
\hline $1265 a$ & Electrolytic Iron & disk \\
\hline 1269 & Line Pipe (AISI 1526 (Modified)) & disk \\
\hline 1270 & LA Steel, Cr-Mo (A336) (F-22) & disk \\
\hline 1271 & LA Steel (HSLA-100) & disk \\
\hline 1286 & Low Alloy Steel (HY 80) & disk \\
\hline $1761 \mathrm{a}$ & Low Alloy Steel & disk \\
\hline $1762 a$ & Low Alloy Steel & disk \\
\hline $1763 a$ & Low Alloy Steel & disk \\
\hline $1764 a$ & Low Alloy Steel & disk \\
\hline 1765 & Low Alloy Steel & disk \\
\hline 1766 & Low Alloy Steel & disk \\
\hline 1767 & Low Alloy Steel & disk \\
\hline 1768 & High-Purity Iron & disk \\
\hline C1285 & LA Steel (A242) (Modified) & disk \\
\hline
\end{tabular}

See Table 101.8 on the website for more information.
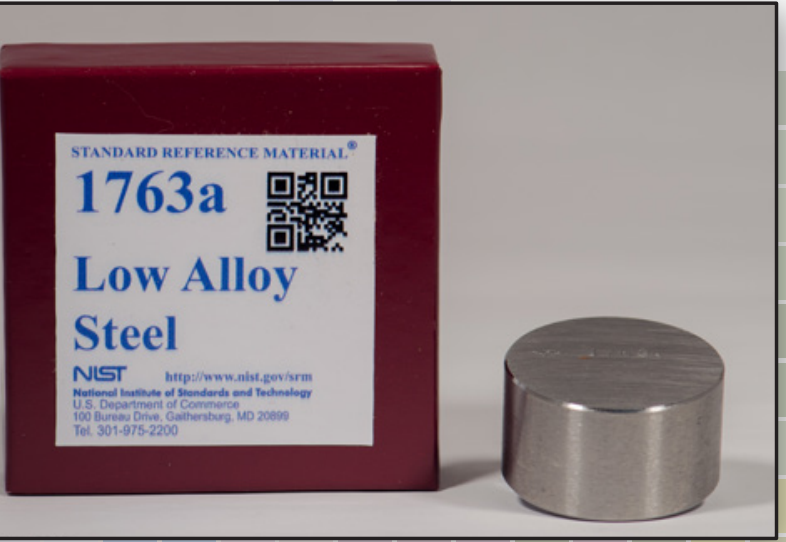

\section{High Alloy Steels \\ (chip form)}

\begin{tabular}{|l|l|c|}
\hline SRM & Description & $\begin{array}{c}\text { Unit of } \\
\text { Issue }\end{array}$ \\
\hline $\mathbf{1 2 6 c}$ & $\begin{array}{l}\text { High-Nickel Steel } \\
\text { (Nominal Mass Fraction 36 \% Ni) } \\
\text { (chip form) }\end{array}$ & $150 \mathrm{~g}$ \\
\hline $\mathbf{3 4 4}$ & $\begin{array}{l}\text { 15 Chromium-7 Nickel Steel } \\
\text { (Mo Precipitation Hardening) }\end{array}$ & $150 \mathrm{~g}$ \\
\hline $\mathbf{3 4 5 b}$ & Fe-Cr-Ni Alloy UNS J92180 (chip form) & $150 \mathrm{~g}$ \\
\hline $\mathbf{3 4 6 a}$ & Valve Steel & $150 \mathrm{~g}$ \\
\hline $\mathbf{8 6 2}$ & High-Temperature Alloy L 605 (chip form) & $100 \mathrm{~g}$ \\
\hline $\mathbf{8 6 8}$ & $\begin{array}{l}\text { High-Temperature Alloy (Fe-Ni-Co) } \\
\text { (chip form) }\end{array}$ & $100 \mathrm{~g}$ \\
\hline
\end{tabular}

See Table 101.4 on the website for more information.

\section{High Temperature Alloys (chip and disk forms)}

\begin{tabular}{|l|l|c|}
\hline SRM & Description & $\begin{array}{c}\text { Unit of } \\
\text { Issue }\end{array}$ \\
\hline $\mathbf{8 6 6}$ & Incoloy $^{\oplus} 800$ (chip form) & $100 \mathrm{~g}$ \\
\hline $\mathbf{8 6 7}$ & Ni-Fe-Cr Alloy UNS N08825 (chip form) & $100 \mathrm{~g}$ \\
\hline $\mathbf{1 2 3 0}$ & High-Temperature Alloy A286 (disk form) & disk \\
\hline $\mathbf{1 2 4 6}$ & Incoloy $^{\circ} 800$ (disk form) & disk \\
\hline $\mathbf{1 2 4 7}$ & Ni-Fe-Cr Alloy UNS N08825 (disk form) & disk \\
\hline $\mathbf{1 2 5 0}$ & High-Temperature Alloy Fe-Ni-Co & disk \\
\hline $\mathbf{C 2 4 0 0}$ & Fe-Cr-Ni Alloy UNS J92180 (disk form) & disk \\
\hline $\mathbf{C 2 4 0 1}$ & HA Steel (ACI-C-4M-Cu) & disk \\
\hline
\end{tabular}

See Table 101.9 on the website for more information.

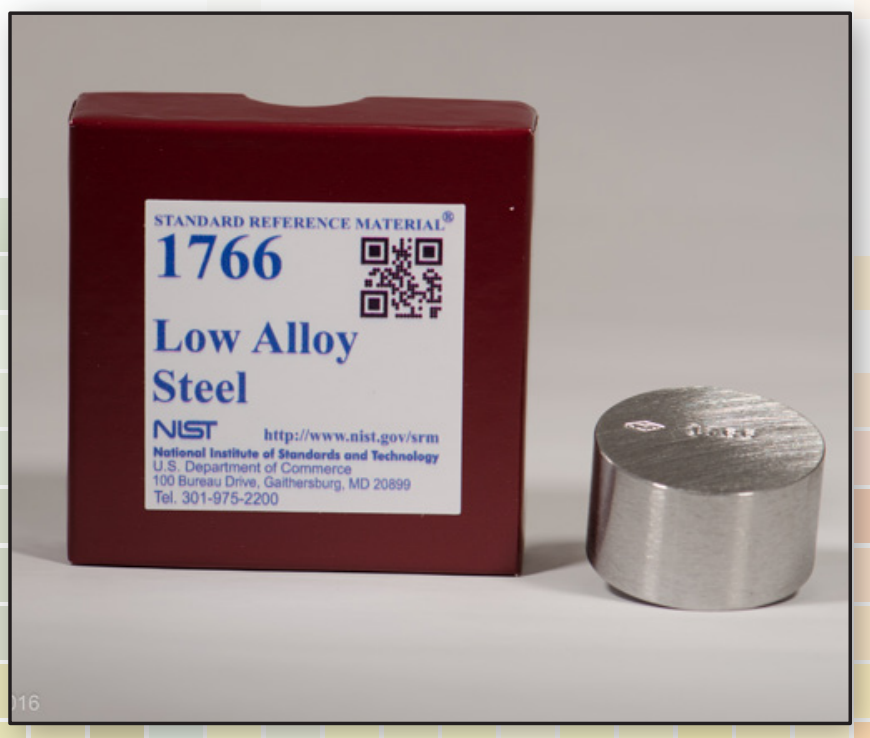


Stainless Steels

(chip form)

\begin{tabular}{|l|l|c|}
\hline SRM & Description & $\begin{array}{c}\text { Unit of } \\
\text { Issue }\end{array}$ \\
\hline $\mathbf{1 0 1} \mathbf{g}$ & 18 Cr-10 Ni Steel (AISI 304L) (powder form) & $100 \mathrm{~g}$ \\
\hline $\mathbf{1 2 3 c}$ & Stainless Steel, Cr-Ni-Nb (AISI 348) & $150 \mathrm{~g}$ \\
\hline $\mathbf{1 3 3 b}$ & Chromium-Molybdenum Steel & $150 \mathrm{~g}$ \\
\hline $\mathbf{1 6 0 b}$ & $\begin{array}{l}\text { Stainless Steel } \\
\text { (Cr 18-Ni 12-Mo 2) (AISI 316) }\end{array}$ & $150 \mathrm{~g}$ \\
\hline $\mathbf{1 6 6} \mathbf{c}$ & Stainless Steel, Low-Carbon (AISI 316L) & $100 \mathrm{~g}$ \\
\hline $\mathbf{3 3 9}$ & 17 Chromium-9 Nickel-0.2 Selenium Steel & $150 \mathrm{~g}$ \\
\hline $\mathbf{3 4 3 a}$ & Stainless Steel (AISI 431) & $150 \mathrm{~g}$ \\
\hline $\mathbf{8 9 3}$ & Stainless Steel (SAE 405) & $150 \mathrm{~g}$ \\
\hline $\mathbf{8 9 5}$ & Stainless Steel (SAE 201) & $150 \mathrm{~g}$ \\
\hline
\end{tabular}

See Table 101.6 on the website for more information.

\section{Stainless Steels (disk form)}

\begin{tabular}{|c|c|c|}
\hline SRM & Description & $\begin{array}{l}\text { Unit of } \\
\text { Issue }\end{array}$ \\
\hline $1155 a$ & Stainless Steel (Cr 18 Ni 12, Mo 2) & disk \\
\hline 1171 & $\begin{array}{l}\text { Stainless Steel Cr 17-Ni 11-Ti } 0.3 \\
\text { (AISI 321) }\end{array}$ & disk \\
\hline 1172 & $\begin{array}{l}\text { Stainless Steel Cr 17-Ni 11-Nb } 0.6 \\
\text { (AISI 348) }\end{array}$ & disk \\
\hline 1219 & Stainless Steel Cr16 - Ni2 (AISI 431) & disk \\
\hline 1223 & Chromium Steel & disk \\
\hline 1295 & Stainless Steel (SAE 405) & disk \\
\hline 1297 & Stainless Steel (SAE 201) & disk \\
\hline C1151a & Stainless Steel 23Cr-7Ni & disk \\
\hline C1152a & Stainless Steel $18 \mathrm{Cr}-11 \mathrm{Ni}$ & disk \\
\hline C1153a & Stainless Steel 17Cr-9Ni & disk \\
\hline C1154a & Stainless Steel 19Cr-13Ni & disk \\
\hline C1296 & Stainless Steel & disk \\
\hline
\end{tabular}

See Table 101.10 on the website for more information.

\section{Tool Steels}

(chip form)

\begin{tabular}{|l|l|c|}
\hline SRM & Description & $\begin{array}{c}\text { Unit of } \\
\text { Issue }\end{array}$ \\
\hline $\mathbf{5 0 c}$ & Tungsten-Chromium-Vanadium Steel & $150 \mathrm{~g}$ \\
\hline $\mathbf{1 3 2 b}$ & Tool Steel (AISI M2) & $150 \mathrm{~g}$ \\
\hline $\mathbf{1 3 4 a}$ & $\begin{array}{l}\text { Molybdenum-Tungsten-Chromium- } \\
\text { Vanadium Steel }\end{array}$ & $150 \mathrm{~g}$ \\
\hline $\mathbf{2 1 7 2}$ & S-7 Tool Steel & $150 \mathrm{~g}$ \\
\hline
\end{tabular}

See Table 101.7 on the website for more information.

\section{Specialty Steels (disk form)}

\begin{tabular}{|l|l|c|}
\hline SRM & Description & $\begin{array}{c}\text { Unit of } \\
\text { Issue }\end{array}$ \\
\hline $\mathbf{1 1 5 7}$ & Tool Steel (AISI M2) & disk \\
\hline $\mathbf{1 1 5 8}$ & $\begin{array}{l}\text { High-Nickel Steel } \\
\text { (Nominal Mass Fraction } 36 \% \mathrm{Ni} \text { ) }\end{array}$ & disk \\
\hline $\mathbf{1 7 7 2}$ & Tool Steel (S-7) & disk \\
\hline
\end{tabular}

See Table 101.11 on the website for more information.

\section{Steelmaking Alloys (powder form)}

These SRMs are for checking chemical methods of analysis for major constituents and selected minor elements. They are furnished as fine powders (usually $<0.1 \mathrm{~mm}$ ).

\begin{tabular}{|l|l|c|}
\hline SRM & Description & $\begin{array}{c}\text { Unit of } \\
\text { Issue }\end{array}$ \\
\hline $\mathbf{5 7 b}$ & Silicon Metal & $40 \mathrm{~g}$ \\
\hline $\mathbf{5 8 a}$ & Ferrosilicon (73 \% Si Regular Grade) & $75 \mathrm{~g}$ \\
\hline $\mathbf{5 9 a}$ & Ferrosilicon & $50 \mathrm{~g}$ \\
\hline $\mathbf{6 4 c}$ & Ferrochromium, High Carbon & $100 \mathrm{~g}$ \\
\hline $\mathbf{6 8 c}$ & High-Carbon Ferromanganese & $100 \mathrm{~g}$ \\
\hline $\mathbf{9 0}$ & Ferrophosphorus & $75 \mathrm{~g}$ \\
\hline $\mathbf{1 9 5}$ & Ferrosilicon (75 \% Si-High Purity Grade) & $75 \mathrm{~g}$ \\
\hline $\mathbf{1 9 6}$ & Ferrochromium, (Low-Carbon) & $100 \mathrm{~g}$ \\
\hline $\mathbf{6 8 9}$ & Ferrochromium Silicon & $100 \mathrm{~g}$ \\
\hline
\end{tabular}

See Table 101.12 on the website for more information. 


\section{Gases in Ferrous Metals (rod and disk forms)}

These SRMs are for determining oxygen and nitrogen by vacuum fusion, inert gas fusion, and neutron activation methods.

\begin{tabular}{|l|l|c|}
\hline SRM & Description & $\begin{array}{c}\text { Unit of } \\
\text { Issue }\end{array}$ \\
\hline $\mathbf{1 0 8 9} \dagger$ & $\begin{array}{l}\text { Steels, Set (consists of SRMs 1095, 1096, } \\
\text { 1097, 1098 and 1099) }\end{array}$ & 5 rods \\
\hline $\mathbf{1 0 9 0}$ & Oxygen in Ingot Iron & rod \\
\hline $\mathbf{1 0 9 1 a}$ & Oxygen in Stainless Steel (AISI 431) & rod \\
\hline $\mathbf{1 0 9 3}$ & Oxygen in Valve Steel & rod \\
\hline $\mathbf{1 0 9 4}$ & Oxygen in Maraging Steel & rod \\
\hline $\mathbf{1 7 5 4}$ & Low-Alloy Steel, AISI 4320 & rod \\
\hline $\mathbf{1 7 5 5}$ & Nitrogen in Low Alloy Steel & disk \\
\hline
\end{tabular}

$\dagger$ These SRMs are sold only as a set designated SRM 1089.

See Table 101.5 on the website for more information.

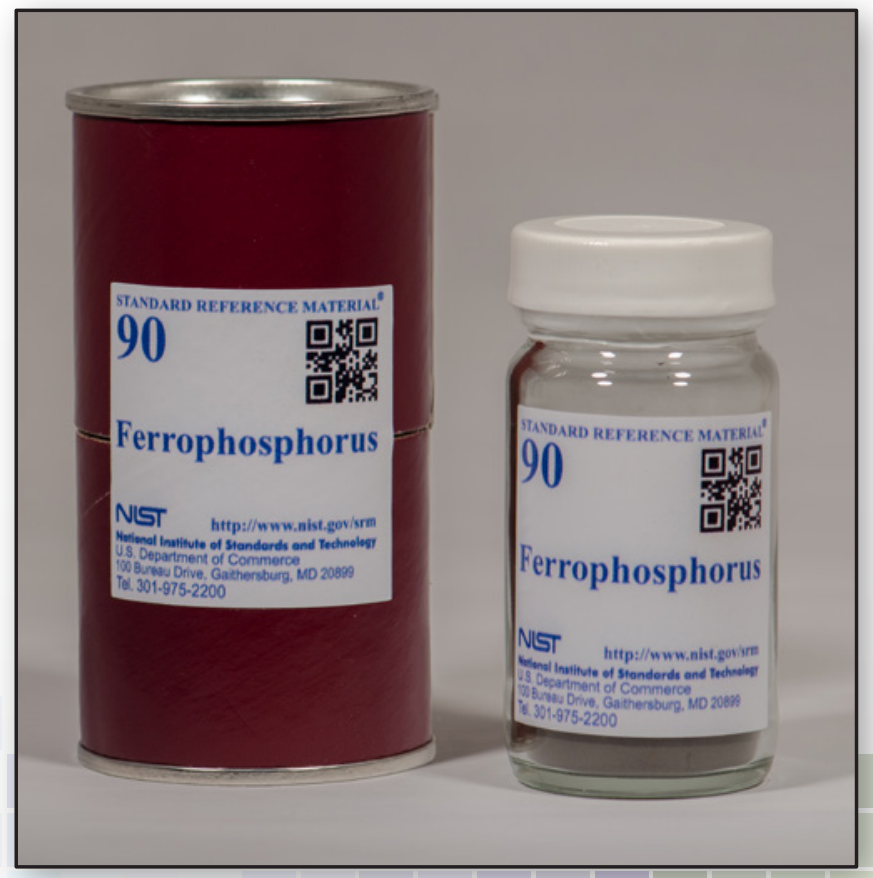

\section{Cast Steels, White Cast Irons, and Ductile Irons (disk form)}

These SRMs are for analysis of cast steels and cast irons by rapid instrumental methods.

\begin{tabular}{|l|l|c|}
\hline SRM & Description & $\begin{array}{c}\text { Unit of } \\
\text { Issue }\end{array}$ \\
\hline $\mathbf{1 1 3 8 a}$ & Cast Steel Standard & block \\
\hline $\mathbf{1 1 3 9}$ & Cast Steel Standard & block \\
\hline $\mathbf{1 1 7 3}$ & Ni-Cr-Mo-V Steel & disk \\
\hline $\mathbf{C 1 1 3 7 a}$ & White Cast Iron & disk \\
\hline C1145a & White Cast Iron & disk \\
\hline C1173 & Cast Steel 3 & disk \\
\hline C1290 & High-Alloy White Cast Iron (HC-250+V) & disk \\
\hline C1291 & $\begin{array}{l}\text { High-Alloy White Cast Iron } \\
\text { (Ni-Hard, Type I) }\end{array}$ & disk \\
\hline C1292 & $\begin{array}{l}\text { High-Alloy White Cast Iron I } \\
\text { (Ni-Hard, Type IV) }\end{array}$ & disk \\
\hline C2424 & Ductile Iron C & disk \\
\hline
\end{tabular}

See Table 101.14 on the website for more information.

\section{Cast Irons (chip form)}

\begin{tabular}{|l|l|c|}
\hline $\mathbf{S R M}$ & Description & $\begin{array}{c}\text { Unit of } \\
\text { Issue }\end{array}$ \\
\hline $\mathbf{4 1}$ & Cast Iron & $150 \mathrm{~g}$ \\
\hline $\mathbf{5 m}$ & Cast Iron & $150 \mathrm{~g}$ \\
\hline $\mathbf{6 g}$ & Cast Iron & $150 \mathrm{~g}$ \\
\hline $\mathbf{8 2 b}$ & Nickel-Chromium Cast Iron & $150 \mathrm{~g}$ \\
\hline $\mathbf{1 0 7 c}$ & Cast Iron (Ni-Cr-Mo) & $150 \mathrm{~g}$ \\
\hline $\mathbf{1 1 5 a}$ & Copper-Nickel-Chromium Cast Iron & $150 \mathrm{~g}$ \\
\hline $\mathbf{1 2 2} \mathbf{i}$ & Cast Iron & $150 \mathrm{~g}$ \\
\hline $\mathbf{3 3 4}$ & Gray Cast Iron & $150 \mathrm{~g}$ \\
\hline $\mathbf{3 4 1}$ & Ductile Cast Iron & $150 \mathrm{~g}$ \\
\hline $\mathbf{3 4 2 a}$ & Nodular Cast Iron & $150 \mathrm{~g}$ \\
\hline $\mathbf{8 9 2}$ & $\begin{array}{l}\text { High-Alloy White Cast Iron } \\
\text { (Ni-Hard, Type IV) }\end{array}$ & $150 \mathrm{~g}$ \\
\hline
\end{tabular}

See Table 101.13 on the website for more information. 


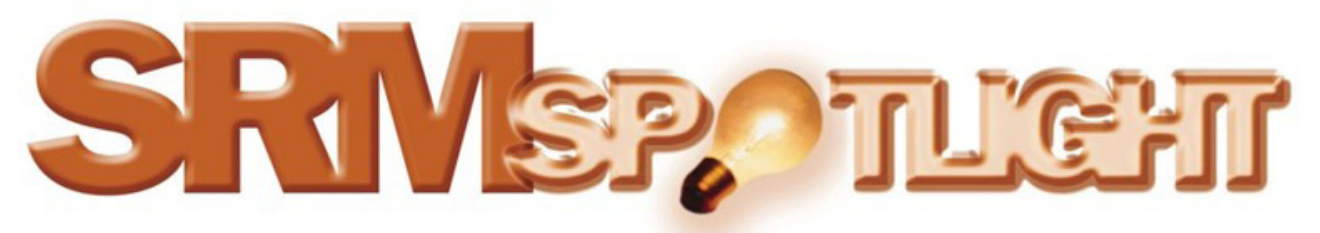

\section{Would you like to be on our mailing list to receive updates of our Standard Reference Materials (SRMs)?}

Join our mailing list to receive the SRM Spotlight newsletter which features information on our newly released SRMs, renewals and revisions. It also includes our exhibit schedule along with other helpful resources.

Sign up on our homepage at https://www.nist.gov/srm under SRM Spotlight.
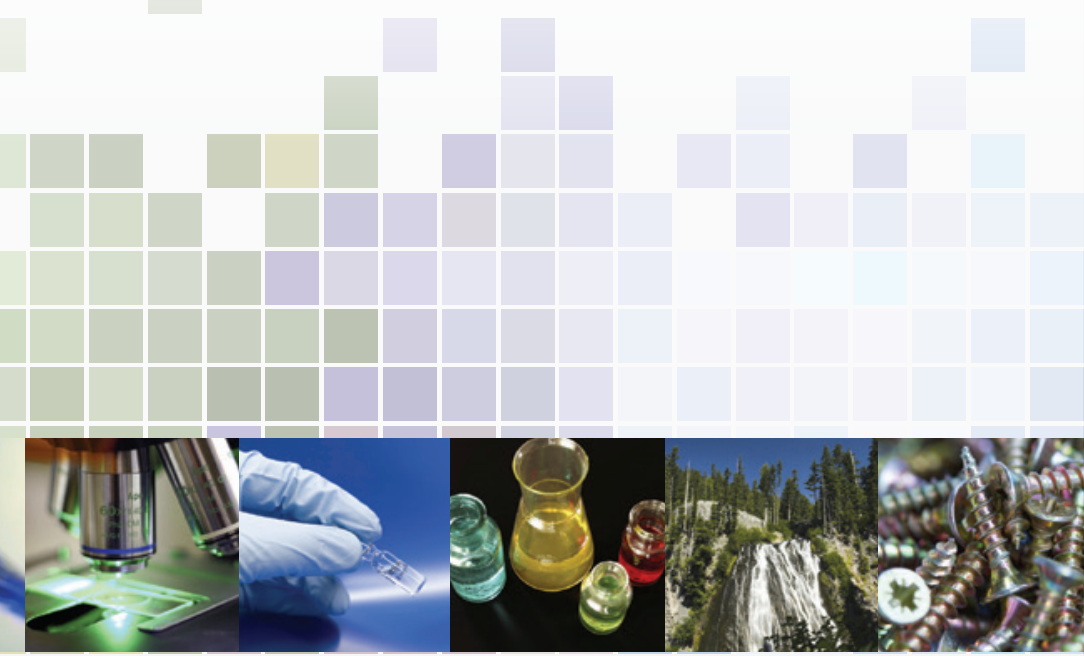

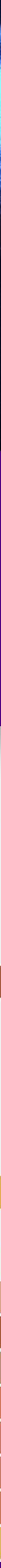

www.nist.gov/srm | Phone: 301.975.2200 | Fax: 301.948.3730 | Email: srminfo@nist.gov 7 
These SRMs are for checking optical emission and X-ray fluorescence spectrometric methods and for other methods of chemical analysis. They consist of alloys selected to provide a wide range of analytical values for elements. They are furnished as chips (small metal turnings), rods, disks, pins or powders from selected portions of commercial ingots. A "C" preceding the SRM number indicates a chill cast sample. Certificates are available on the website with information regarding specific alloy composition.

\section{Aluminum Base Alloys (chip and disk forms)}

These SRMs are intended for analyses of aluminum alloys by chemical and instrumental methods. SRMs 1710 through 1713 are specially prepared to include low levels of cadmium and lead encountered in the analysis of recycled aluminum. SRM 2426 is a hot-dip coating alloy for sheet steel applications.

\begin{tabular}{|l|l|c|}
\hline SRM & Description & $\begin{array}{c}\text { Unit of } \\
\text { Issue }\end{array}$ \\
\hline $\mathbf{8 7 a}$ & Silicon-Aluminum Alloy (chip form) & $75 \mathrm{~g}$ \\
\hline $\mathbf{8 5 3 a}$ & Aluminum Alloy 3004 (chip form) & $40 \mathrm{~g}$ \\
\hline $\mathbf{8 5 4 a}$ & Aluminum Alloy 5182 (chip form) & $40 \mathrm{~g}$ \\
\hline $\mathbf{8 5 5 a}$ & Aluminum Casting Alloy 356 (chip form) & $30 \mathrm{~g}$ \\
\hline $\mathbf{8 5 6 a}$ & Aluminum Casting Alloy 380 (chip form) & $30 \mathrm{~g}$ \\
\hline $\mathbf{8 5 8}$ & Aluminum Alloy 6011 (chip form) & $35 \mathrm{~g}$ \\
\hline $\mathbf{1 2 4 0}$ c & Aluminum Alloy 3004 & disk \\
\hline $\mathbf{1 2 4 1} \mathbf{c}$ & Aluminum Alloy 5182 & disk \\
\hline $\mathbf{1 2 5 5 b}$ & Aluminum Alloy 356 & disk \\
\hline $\mathbf{1 2 5 6 b}$ & Aluminum Alloy 380 & disk \\
\hline $\mathbf{1 2 5 8}$-I & Aluminum Alloy 6011 & disk \\
\hline $\mathbf{1 2 5 9}$ & Aluminum Alloy 7075 & disk \\
\hline $\mathbf{1 7 1 0}$ & Aluminum Alloy 3004 & disk \\
\hline $\mathbf{1 7 1 1}$ & Aluminum Alloy 3004 & disk \\
\hline $\mathbf{1 7 1 3}$ & Aluminum Alloy 5182 & disk \\
\hline $\mathbf{2 4 2 6}$ & $55 \%$ Aluminum-Zinc Alloy & $40 \mathrm{~g}$ \\
\hline
\end{tabular}

See Table 102.1 on the website for more information.

\section{Cobalt Base Alloys (chip and disk forms)}

\begin{tabular}{|l|l|c|}
\hline SRM & Description & $\begin{array}{c}\text { Unit of } \\
\text { Issue }\end{array}$ \\
\hline $\mathbf{8 6 2}$ & High-Temperature Alloy L 605 (chip form) & $100 \mathrm{~g}$ \\
\hline $\mathbf{1 2 4 2}$ & High Temperature Alloy L 605 & disk \\
\hline $\mathbf{1 7 7 5}$ & Refractory Alloy MP-35-N & disk \\
\hline $\mathbf{2 1 7 5}$ & Refractory Alloy MP-35-N (chip form) & $150 \mathrm{~g}$ \\
\hline
\end{tabular}

See Table 102.2 on the website for more information.

\section{Copper Base Alloys (chip and rod forms)}

\begin{tabular}{|l|l|c|}
\hline SRM & Description & $\begin{array}{c}\text { Unit of } \\
\text { Issue }\end{array}$ \\
\hline $\mathbf{1 5 8 a}$ & Silicon Bronze (chip form) & $150 \mathrm{~g}$ \\
\hline $\mathbf{4 5 8}$ & Beryllium-Copper (17510) (chip form) & $50 \mathrm{~g}$ \\
\hline $\mathbf{4 5 9}$ & Beryllium-Copper (17200) (chip form) & $50 \mathrm{~g}$ \\
\hline $\mathbf{4 6 0}$ & Beryllium-Copper Alloy (chip form) & $50 \mathrm{~g}$ \\
\hline $\mathbf{8 7 1}$ & Phosphor Bronze (CDA 521) (chip form) & $100 \mathrm{~g}$ \\
\hline $\mathbf{8 7 2}$ & Phosphor Bronze (CDA 544) (chip form) & $100 \mathrm{~g}$ \\
\hline $\mathbf{8 7 4}$ & $\begin{array}{l}\text { Cupro-Nickel, 10\% (CDA 706) } \\
\text { "HIGH-PURITY" (chip form) }\end{array}$ & $100 \mathrm{~g}$ \\
\hline $\mathbf{8 7 5}$ & $\begin{array}{l}\text { Cupro-76t5Nickel, 10 \% (CDA 706) } \\
\text { "DOPED” (chip form) }\end{array}$ & $100 \mathrm{~g}$ \\
\hline $\mathbf{8 8 0}$ & Nickel Silver (CDA 770) (chip form) & $100 \mathrm{~g}$ \\
\hline $\mathbf{1 0 3 4}$ & Unalloyed Copper & rod \\
\hline $\mathbf{1 0 3 5}$ & Leaded-Tin Bronze Alloy (chip form) & $50 \mathrm{~g}$ \\
\hline
\end{tabular}

See Table 102.3 on the website for more information.

\section{Copper Base Alloys (block and disk forms)}

The SRMs with a "C" prefix are chill-cast blocks, $31 \mathrm{~mm}$ square and $19 \mathrm{~mm}$ thick; the others are wrought disks, 31 $\mathrm{mm}$ in diameter and $19 \mathrm{~mm}$ thick. Both forms have nearly identical elemental compositions.

\begin{tabular}{|c|c|c|}
\hline SRM & Description & $\begin{array}{l}\text { Unit of } \\
\text { Issue }\end{array}$ \\
\hline 1107 & Naval Brass UNS 46400 & disk \\
\hline 1110 & Red Brass B & disk \\
\hline 1111 & Red Brass Standard & disk \\
\hline 1112 & Gilding Metal & disk \\
\hline 1113 & Gilding Metal & disk \\
\hline 1114 & Gilding Metal & disk \\
\hline 1115 & $\begin{array}{l}\text { Commercial Bronze Standard for Optical } \\
\text { Emission and X-ray Spectroscopic Analysis }\end{array}$ & disk \\
\hline 1116 & $\begin{array}{l}\text { Commercial Bronze Standard for Optical } \\
\text { Emission and X-ray Spectroscopic Analysis }\end{array}$ & disk \\
\hline 1117 & $\begin{array}{l}\text { Commercial Bronze Standard for Optical } \\
\text { Emission and X-ray Spectroscopic Analysis }\end{array}$ & disk \\
\hline 1124 & Free Cutting Brass (UNS C36000) & disk \\
\hline $1276 a$ & Cupro-Nickel (CDA 715) & disk \\
\hline C1114 & Gilding Metal C (block) & block \\
\hline C1115 & Commercial Bronze A (block) & block \\
\hline C1117 & Commercial Bronze C (block) & block \\
\hline
\end{tabular}

See Table 102.4 on the website for more information. 


\section{Copper "Benchmark" (block, chip and rod forms)}

SRMs with a "C" prefix are chill-cast blocks approximately $32 \mathrm{~mm}$ square and $19 \mathrm{~mm}$ thick.

\begin{tabular}{|l|l|c|}
\hline SRM & Description & $\begin{array}{c}\text { Unit of } \\
\text { Issue }\end{array}$ \\
\hline $\mathbf{3 9 9}$ & Unalloyed Copper - Cu VI (chip form) & $50 \mathrm{~g}$ \\
\hline $\mathbf{4 0 0}$ & Unalloyed Copper - Cu VII (chip form) & $50 \mathrm{~g}$ \\
\hline $\mathbf{4 5 4}$ & Unalloyed Copper XI (chips) & $35 \mathrm{~g}$ \\
\hline $\mathbf{4 5 7}$ & Unalloyed Copper IV (solid) & rod \\
\hline $\mathbf{4 9 4}$ & Unalloyed Copper I (solid) & rod \\
\hline $\mathbf{4 9 5}$ & Unalloyed Copper II (solid) & rod \\
\hline $\mathbf{4 9 8}$ & Unalloyed Copper V (solid) & rod \\
\hline $\mathbf{4 9 9}$ & Unalloyed Copper VI (solid) & rod \\
\hline $\mathbf{5 0 0}$ & Unalloyed Copper - Cu VII (solid) & block \\
\hline C1251a & Phosphorus Deoxidized Copper - Cu VIII & block \\
\hline C1252a & Phosphorus Deoxidized Copper - Cu IX & block \\
\hline C1253a & Phosphorus Deoxidized Copper - Cu X & \\
\hline
\end{tabular}

See Table 102.5 on the website for more information.

\section{Lead-Base Alloys (disk and powder forms)}

SRMs in the form of disks are approximately $50 \mathrm{~mm}$ in diameter and $16 \mathrm{~mm}$ thick. They are intended for use with optical emission spectrometric methods of analysis.

\begin{tabular}{|l|l|c|}
\hline SRM & Description & $\begin{array}{c}\text { Unit of } \\
\text { Issue }\end{array}$ \\
\hline $\mathbf{5 3 e}$ & Lead-Base Bearing Metal (84Pb-10Sb-6Sn) & $150 \mathrm{~g}$ \\
\hline $\mathbf{1 2 7 b}$ & Solder $(40 \mathrm{Sn}-60 \mathrm{~Pb})$ & $150 \mathrm{~g}$ \\
\hline $\mathbf{1 1 2 9}$ & Solder $(63 \mathrm{Sn}-37 \mathrm{~Pb})$ & $200 \mathrm{~g}$ \\
\hline $\mathbf{1 1 3 1}$ & Solder $(40 \mathrm{Sn}-60 \mathrm{~Pb})$ & disk \\
\hline $\mathbf{1 1 3 2}$ & Lead-Base Bearing Metal (84Pb-10Sb-6Sn) & disk \\
\hline $\mathbf{C 2 4 1 5 a}$ & Battery Lead (UNS 52770) & disk \\
\hline $\mathbf{C 2 4 1 6}$ & Bullet Lead & disk \\
\hline $\mathbf{C 2 4 1 7}$ & Lead-Base Alloy & disk \\
\hline $\mathbf{C 2 4 1 8}$ & High-Purity Lead & disk \\
\hline
\end{tabular}

See Table 102.10 on the website for more information.

\section{Nickel Base Alloys (chip and disk forms)}

\begin{tabular}{|l|l|c|}
\hline SRM & Description & $\begin{array}{c}\text { Unit of } \\
\text { Issue }\end{array}$ \\
\hline $\mathbf{3 4 9 a}$ & Waspaloy & $150 \mathrm{~g}$ \\
\hline $\mathbf{8 6 1}$ & $\begin{array}{l}\text { Nickel-based Superalloy PWA 1484 } \\
\text { (chip form) }\end{array}$ & $50 \mathrm{~g}$ \\
\hline $\mathbf{8 6 4}$ & Nickel Alloy UNS N06600 (chip form) & $100 \mathrm{~g}$ \\
\hline $\mathbf{8 6 5}$ & Inconel 625 (chip form) & $150 \mathrm{~g}$ \\
\hline $\mathbf{8 8 2}$ & $\begin{array}{l}\text { Nickel-Copper Alloy (65Ni-31Cu-3Al) } \\
\text { (ship form) }\end{array}$ & $100 \mathrm{~g}$ \\
\hline $\mathbf{8 9 7}$ & Tracealloy A (chip form) & $35 \mathrm{~g}$ \\
\hline $\mathbf{8 9 9}$ & Tracealloy C (chip form) & $35 \mathrm{~g}$ \\
\hline $\mathbf{1 1 5 9}$ & Electronic and Magnetic Alloy Standard & disk \\
\hline $\mathbf{1 1 6 0}$ & Elec/Mag Ni-Mo-Fe & disk \\
\hline $\mathbf{1 2 4 3}$ & Ni-Cr-Co Alloy UNS N07001 (disk form) & disk \\
\hline $\mathbf{1 2 4 4}$ & Nickel Alloy UNS N06600 & disk \\
\hline $\mathbf{1 2 4 9}$ & $\begin{array}{l}\text { Ni-Cr-Fe-Nb-Mo Alloy UNS N077178 } \\
\text { (disk form) }\end{array}$ & disk \\
\hline $\mathbf{1 7 7 5}$ & Refractory Alloy MP-35-N & disk \\
\hline $\mathbf{2 1 7 5}$ & Refractory Alloy MP-35-N (chip form) & $150 \mathrm{~g}$ \\
\hline $\mathbf{C 1 2 4 8}$ & Nickel-Copper Alloy & disk \\
\hline $\mathbf{C 2 4 0 2}$ & Hastelloy 7C & disk \\
\hline
\end{tabular}

See Table 102.12 on the website for more information.

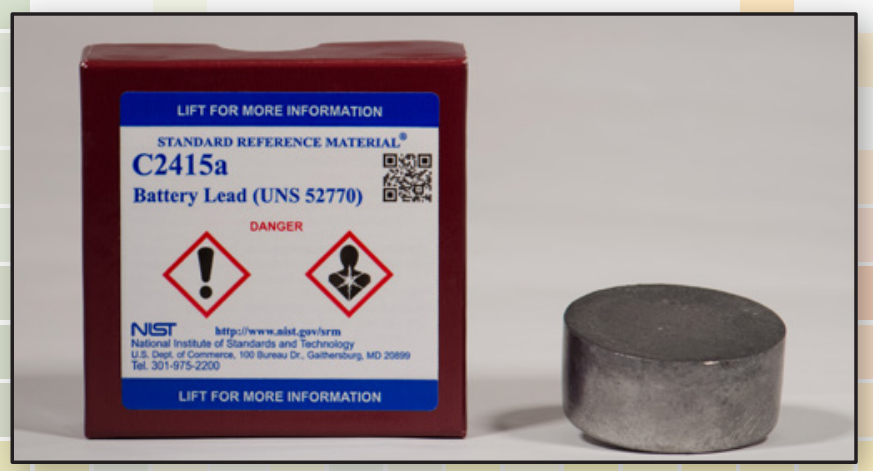




\section{Tin Base Alloys}

\begin{tabular}{|l|l|c|}
\hline SRM & Description & $\begin{array}{c}\text { Unit of } \\
\text { Issue }\end{array}$ \\
\hline $\mathbf{5 4 d}$ & Bearing Metal (Tin Base) & $75 \mathrm{~g}$ \\
\hline $\mathbf{1 7 2 7}$ & Anode Tin & block \\
\hline $\mathbf{1 7 2 8}$ & Tin Alloy (Sn-3Cu-0.5Ag) & disk \\
\hline $\mathbf{1 7 2 9}$ & Tin Alloy (97Sn-3Pb) & disk \\
\hline
\end{tabular}

See Table 102.15 on the website for more information.

Titanium Base Alloys (chip and disk forms)

\begin{tabular}{|c|c|c|}
\hline SRM & Description & $\begin{array}{l}\text { Unit of } \\
\text { Issue }\end{array}$ \\
\hline $173 \mathrm{c}$ & Titanium Alloy UNS R56400 (chip form) & $50 \mathrm{~g}$ \\
\hline 641 & $\begin{array}{l}\text { Spectroscopic Titanium- } \\
\text { Base Standards Titanium Alloy, } 8 \text { Mn (A) }\end{array}$ & disk \\
\hline 642 & $\begin{array}{l}\text { Spectroscopic Titanium-Base Standards } \\
\text { Titanium Alloy, } 8 \mathrm{Mn} \text { (B) }\end{array}$ & disk \\
\hline 643 & $\begin{array}{l}\text { Spectroscopic Titanium-Base Standards } \\
\text { Titanium Alloy, } 8 \mathrm{Mn}(\mathrm{C})\end{array}$ & disk \\
\hline 647 & Titanium Alloy, Al-Mo-Sn-Zr (chip form) & $50 \mathrm{~g}$ \\
\hline 648 & $\begin{array}{l}\text { Titanium-Base Alloy } 5 \mathrm{Al}-2 \mathrm{Sn}-2 \mathrm{Zr}-4 \mathrm{Cr}-4 \mathrm{Mo} \\
\text { (chip form) }\end{array}$ & $50 \mathrm{~g}$ \\
\hline 649 & $\begin{array}{l}\text { Titanium-Base Alloy (15V-3Al-3Cr-3Sn) } \\
\text { (chip form) }\end{array}$ & $50 \mathrm{~g}$ \\
\hline $654 b$ & Titanium Alloy, Al-V & disk \\
\hline 1128 & Titanium -Base Alloy (15V-3Al-3Cr-3Sn) & disk \\
\hline 2061 & TiAl(NbW) Alloy for Microanalysis & cube \\
\hline 2062 & Titanium Alloy, Al-Nb-W & disk \\
\hline 2431 & Titanium Base Alloy (chip form) & $50 \mathrm{~g}$ \\
\hline 2432 & $\begin{array}{l}\text { Titanium-Base Alloy 10V-2Fe-3Al } \\
\text { (chip form) }\end{array}$ & $50 \mathrm{~g}$ \\
\hline 2433 & $\begin{array}{l}\text { Titanium-Base Alloy 8Al-1Mo-1V } \\
\text { (chip form) }\end{array}$ & $50 \mathrm{~g}$ \\
\hline 2452 & Hydrogen In Titanium Alloy (chip form) & $10 \mathrm{~g}$ \\
\hline $2453 a$ & $\begin{array}{l}\text { Hydrogen In Titanium Alloy } \\
\text { (Nominal Mass Fraction } 125 \mathrm{mg} / \mathrm{kg} \mathrm{H} \text { ) } \\
\text { (chip form) }\end{array}$ & $10 \mathrm{~g}$ \\
\hline 2454 & Hydrogen In Titanium Alloy (chip form) & $10 \mathrm{~g}$ \\
\hline
\end{tabular}

See Table 102.16 on the website for more information.

\section{Zinc Base Alloys (block, chip and disk forms)}

SRM 1738 through 1742 and SRM 2139 are specially prepared alloys primarily intended for use with spectrometric methods of analysis.

\begin{tabular}{|l|l|c|}
\hline SRM & Description & $\begin{array}{c}\text { Unit of } \\
\text { Issue }\end{array}$ \\
\hline $\mathbf{9 4 c}$ & Zinc-Base Alloy (Die Casting) (chip form) & $150 \mathrm{~g}$ \\
\hline $\mathbf{6 2 5}$ & $\begin{array}{l}\text { Spectrographic Zinc-Base Die-Casting } \\
\text { Alloy A }\end{array}$ & block \\
\hline $\mathbf{6 2 6}$ & $\begin{array}{l}\text { Spectrographic Zinc-Base Die-Casting } \\
\text { Alloy B }\end{array}$ & block \\
\hline $\mathbf{6 2 7}$ & $\begin{array}{l}\text { Spectrographic Zinc-Base Die-Casting } \\
\text { Alloy C }\end{array}$ & block \\
\hline $\mathbf{6 2 8}$ & $\begin{array}{l}\text { Spectrographic Zinc-Base Die-Casting } \\
\text { Alloy D }\end{array}$ & block \\
\hline $\mathbf{6 2 9}$ & $\begin{array}{l}\text { Spectrographic Zinc-Base Die-Casting } \\
\text { Alloy E }\end{array}$ & block \\
\hline $\mathbf{6 3 0}$ & $\begin{array}{l}\text { Spectrographic Zinc-Base Die-Casting } \\
\text { Alloy F }\end{array}$ & block \\
\hline $\mathbf{6 3 1}$ & Spectrographic Zinc Spelter (Modified) & block \\
\hline $\mathbf{1 7 3 8}$ & Zinc-Aluminum Alloy & disk \\
\hline $\mathbf{1 7 3 9}$ & Zinc-Aluminum Alloy & disk \\
\hline $\mathbf{1 7 4 0}$ & Zinc-Aluminum Alloy & disk \\
\hline $\mathbf{1 7 4 1}$ & Zinc-Aluminum Alloy & disk \\
\hline $\mathbf{1 7 4 2}$ & Zinc-Aluminum Alloy \\
\hline $\mathbf{2 1 3 9}$ & Zinc-Aluminum Alloy \\
\hline $\mathbf{2 4 2 6}$ & 55\% Aluminum-Zinc Alloy (chip form) & disk \\
\hline
\end{tabular}

See Table 102.17 on the website for more information.

\section{Zirconium Base Alloys} (chip form)

\begin{tabular}{|l|l|c|}
\hline SRM & Description & $\begin{array}{c}\text { Unit of } \\
\text { Issue }\end{array}$ \\
\hline 360b & Zirconium (Sn-Fe-Cr) Alloy & $100 \mathrm{~g}$ \\
\hline
\end{tabular}

See Table 102.18 on the website for more information.

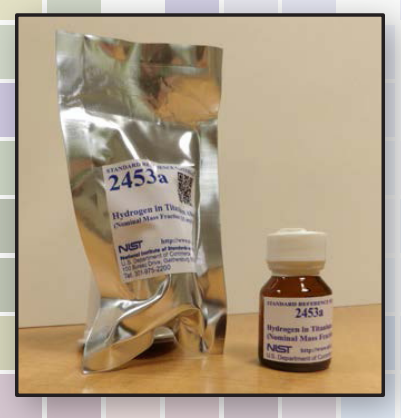



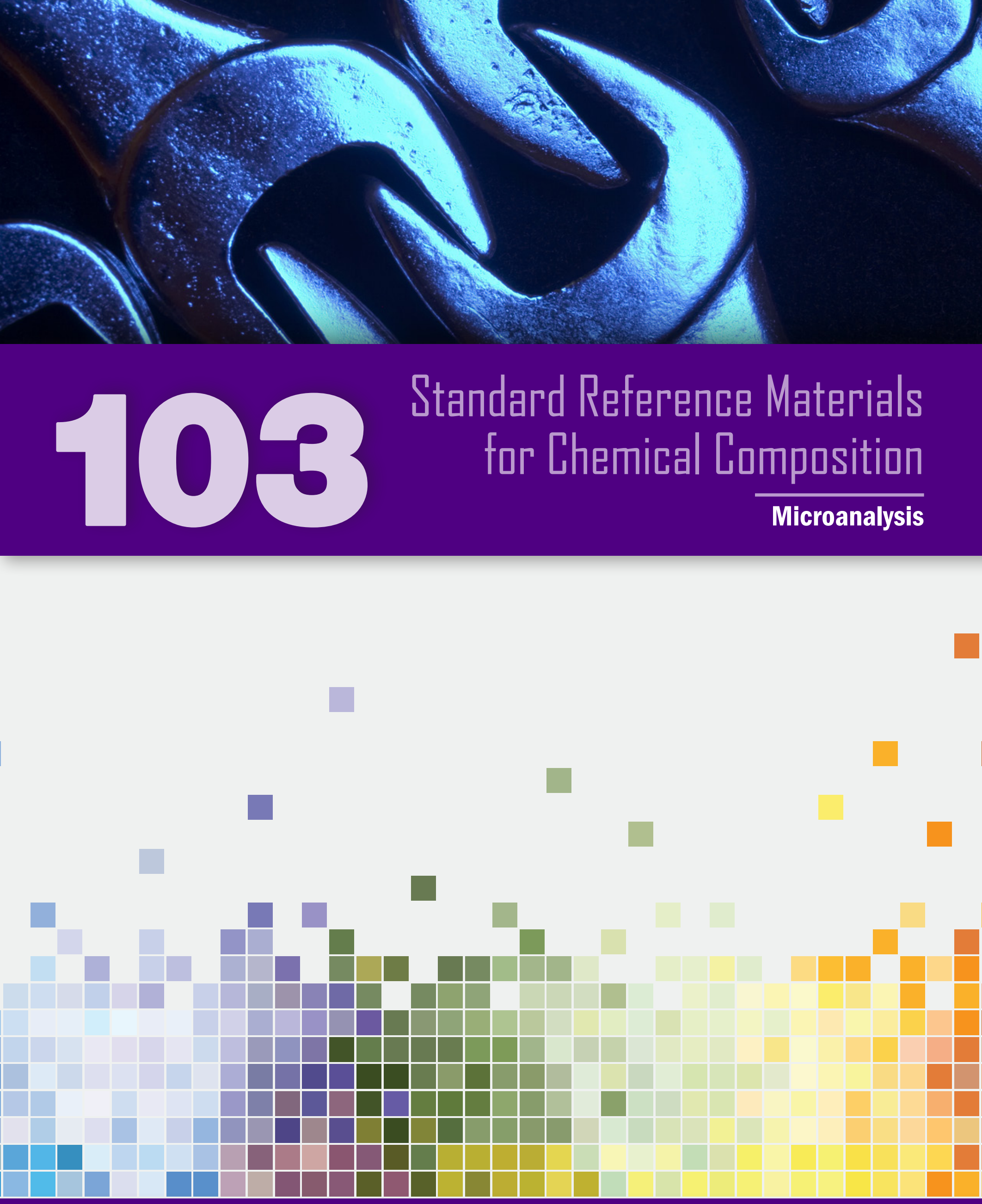

www.nist.gov/srm | Phone: 301.975.2200 | Fax: 301.948.3730 | Email: srminfo@nist.gov 


\section{Metals \\ (wire, disk and cube forms)}

\begin{tabular}{|l|l|c|}
\hline SRM & Description & $\begin{array}{c}\text { Unit of } \\
\text { Issue }\end{array}$ \\
\hline $\mathbf{4 8 0}$ & $\begin{array}{l}\text { Tungsten 20 \% - Molybdenum Alloy } \\
\text { Electron Microprobe Standard }\end{array}$ & disk \\
\hline $\mathbf{4 8 1}$ & Gold-Silver Wires for Microprobe Analysis & set (6) \\
\hline $\mathbf{4 8 2}$ & Gold-Copper Wires for Microprobe Analysis & set (6) \\
\hline $\mathbf{2 0 6 1}$ & TiAl(NbW) Alloy for Microanalysis & cube \\
\hline
\end{tabular}

See Table 103.1 on the website for more information.

\section{Synthetic Glasses for Microanalysis (rod and microsphere forms)}

The glass SRM listed below is suitable for microanalysis, such as electron probe microanalysis (EMPA) secondary ion mass spectrometry (SIMS) and other methods that require high homogeneity.

\begin{tabular}{|l|l|c|}
\hline SRM & Description & $\begin{array}{c}\text { Unit of } \\
\text { Issue }\end{array}$ \\
\hline 2066 & K-411 Glass Microspheres & $50 \mathrm{mg}$ \\
\hline
\end{tabular}

See Table 103.2 on the website for more information.

\section{Semiconductor Thin Film for the Composition of Thin Films}

Standard Reference Material SRM 2841 is intended for use as a reference standard for analytical methods that measure the composition of thin films, such as electron microprobe analysis (EMPA), photoluminesence (PL), auger electron spectroscopy (AES) and X-ray photoelectron spectroscopy (XPS). The SRM consists of an epitaxial layer of ALxGa1-xAs, $3 \mu \mathrm{m}$ thick, on a $1 \mathrm{~cm} \times 1 \mathrm{~cm}$ square of GaAs substrate. The semiconductor chip is attached with carbon tape to a $2.5 \mathrm{~cm}$ diameter stainless steel disk for labeling and handling.

\begin{tabular}{|l|l|c|}
\hline SRM & Description & $\begin{array}{c}\text { Unit of } \\
\text { Issue }\end{array}$ \\
\hline $\mathbf{2 8 4 1}$ & $\begin{array}{l}\text { Semiconductor Thin Film: } \\
\text { AlxGa1-xAs Epitaxial Layers } \\
\text { (Al mole fraction } x \text { near 0.20) }\end{array}$ & disk \\
\hline $\mathbf{2 8 4 2}$ & $\begin{array}{l}\text { Semiconductor Thin Film: } \\
\text { AlxGa1-xAs Epitaxial Layers } \\
(\text { Al mole fraction } x \text { near 0.30) }\end{array}$ & disk \\
\hline $\mathbf{8 0 9 5}$ & Si $_{1-\mathrm{x}} \mathrm{Ge}_{\mathrm{X}}$ Films on $\mathrm{Si}$ & $\begin{array}{c}\text { 2 wafers, } \\
\text { each level }\end{array}$ \\
\hline
\end{tabular}

See Table 103.4 on the website for more information.

\section{Nanomaterials: Composition}

\begin{tabular}{|l|l|c|}
\hline SRM & Description & $\begin{array}{c}\text { Unit of } \\
\text { Issue }\end{array}$ \\
\hline $\mathbf{2 4 8 3}$ & Single-Wall Carbon Nanotubes (Raw Soot) & $250 \mathrm{mg}$ \\
\hline
\end{tabular}

See Table 103.5 on the website for more information.

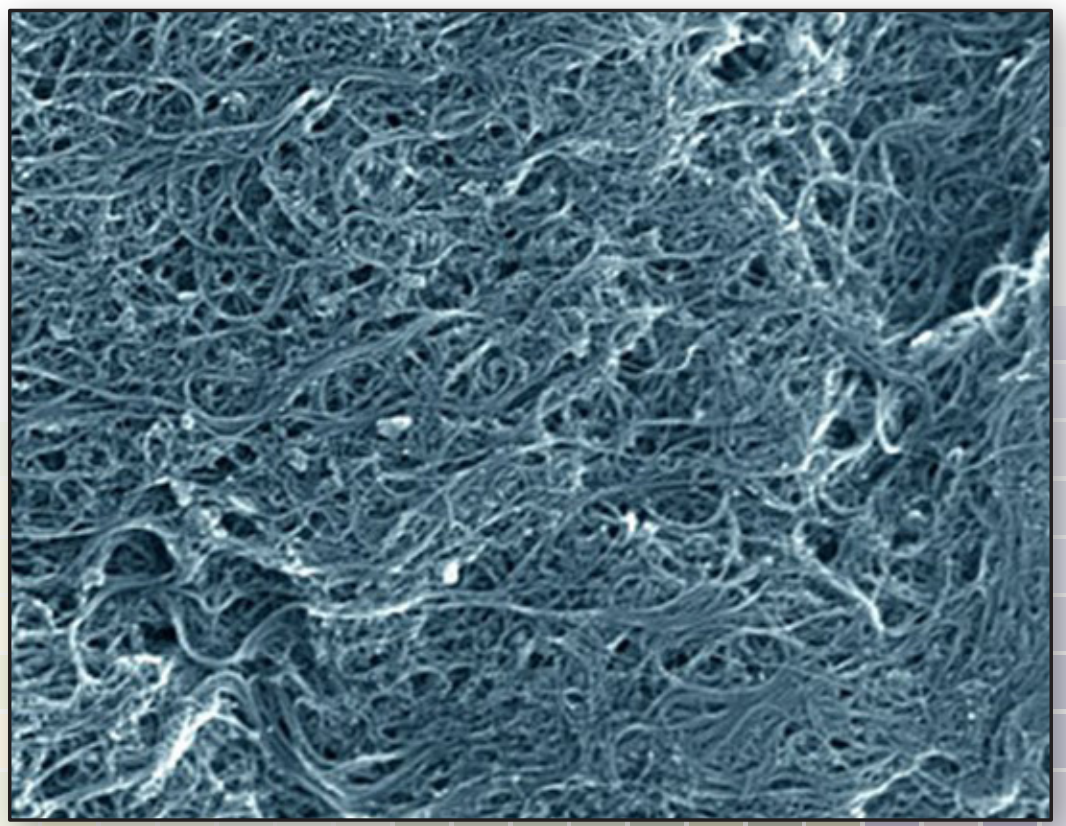

Scanning Electron Microscopy Image of SRM 2483 

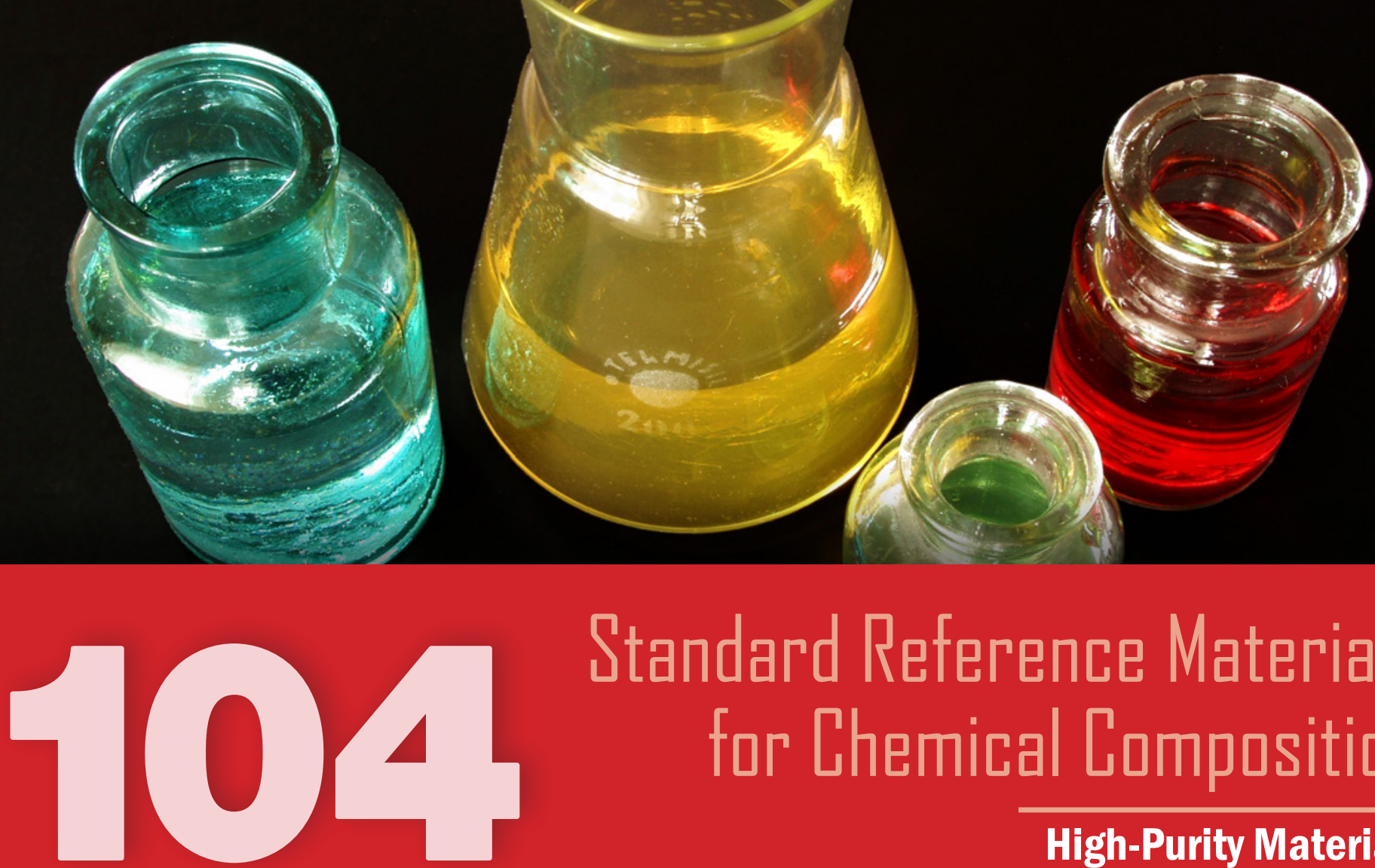

Standard Reference Materials far Chemical Campasitian

High-Purity Materials

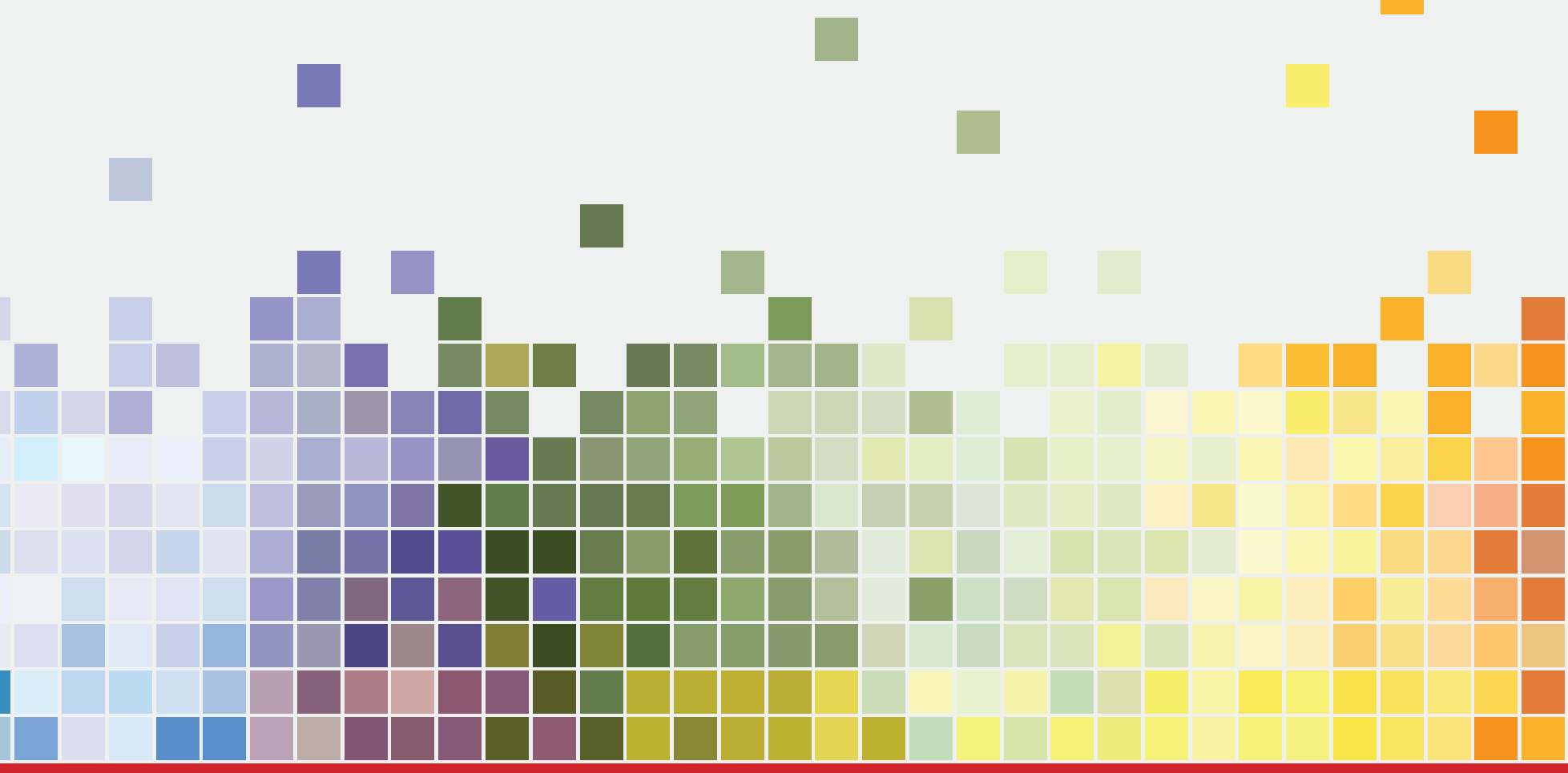

www.nist.gov/srm | Phone: 301.975.2200 | Fax: 301.948.3730 | Email: srminfo@nist.gov 


\section{High Purity Metals (solid forms)}

These SRMs are for determining impurity elements in high purity metals.

\begin{tabular}{|l|l|c|}
\hline SRM & Description & $\begin{array}{c}\text { Unit of } \\
\text { Issue }\end{array}$ \\
\hline $\mathbf{6 8 2}$ & High-Purity Zinc & block \\
\hline $\mathbf{6 8 3}$ & Zinc Metal & block \\
\hline $\mathbf{6 8 5 r}$ & High-Purity Gold (rod) & $15 \mathrm{~g}$ \\
\hline $\mathbf{7 2 8}$ & Intermediate-Purity Zinc (pellet) & $450 \mathrm{~g}$ \\
\hline $\mathbf{8 8 5}$ & Refined Copper (pin) & $200 \mathrm{~g}$ \\
\hline
\end{tabular}

See Table 104.1 on the website for more information.

\section{Stoichiometry (powder form)}

These SRMs are defined as primary, working, and secondary standards in accordance with recommendations of the Analytical Chemistry Section of the International Union of Pure and Applied Chemistry [Ref. Analyst 90, 251 (1965)]. These definitions are as follows:

\section{Primary Standard:}

A commercially available substance of purity $100 \pm 0.02 \%$

(Purity $99.98+\%)$.

Working Standard:

A commercially available substance of purity $100 \pm 0.05 \%$

(Purity 99. $95+\%$ ).

Secondary Standard:

A substance of lower purity which can be standardized against a primary grade standard.

\begin{tabular}{|c|c|c|}
\hline SRM & Description & $\begin{array}{l}\text { Unit of } \\
\text { Issue }\end{array}$ \\
\hline $17 f$ & Sucrose Optical Rotation & $60 \mathrm{~g}$ \\
\hline $84 \mathrm{~L}$ & Potassium Hydrogen Phthalate & $60 \mathrm{~g}$ \\
\hline $136 f$ & $\begin{array}{l}\text { Potassium Dichromate, } \\
\text { (Oxidimetric Standard) }\end{array}$ & $60 \mathrm{~g}$ \\
\hline $154 c$ & Titanium Dioxide & $90 \mathrm{~g}$ \\
\hline $350 c$ & Benzoic Acid (Acidimetric) & $30 \mathrm{~g}$ \\
\hline $351 \mathrm{a}$ & Sodium Carbonate & $50 \mathrm{~g}$ \\
\hline $723 \mathrm{e}$ & Tris Acidimetric & $50 \mathrm{~g}$ \\
\hline $917 \mathrm{c}$ & D-Glucose (Dextrose) & $50 \mathrm{~g}$ \\
\hline 973 & Boric Acid Acidimetric Standard & $100 \mathrm{~g}$ \\
\hline $999 c$ & $\begin{array}{l}\text { Potassium Chloride Primary Standard } \\
\left(\text { Dried at } 500^{\circ} \mathrm{C}\right)\end{array}$ & $30 \mathrm{~g}$ \\
\hline 8040 & $\begin{array}{l}\text { Sodium Oxalate }\left(\mathrm{Na}_{2} \mathrm{C}_{2} \mathrm{O}_{4}\right) \\
\text { Reductometric Standard }\end{array}$ & $60 \mathrm{~g}$ \\
\hline
\end{tabular}

See Table 104.3 on the website for more information.

\section{Microchemistry (powder form)}

\begin{tabular}{|l|l|c|}
\hline SRM & Description & $\begin{array}{c}\text { Unit of } \\
\text { Issue }\end{array}$ \\
\hline $\mathbf{1 4 1 d}$ & Acetanilide & $2 \mathrm{~g}$ \\
\hline $\mathbf{1 4 3 d}$ & Cystine & $2 \mathrm{~g}$ \\
\hline $\mathbf{1 4 8}$ & Nicotinic Acid & $2 \mathrm{~g}$ \\
\hline $\mathbf{2 1 4 1}$ & Urea & $2 \mathrm{~g}$ \\
\hline $\mathbf{2 1 4 3}$ & p-Fluorobenzoic Acid & $2 \mathrm{~g}$ \\
\hline $\mathbf{2 1 4 4}$ & m-Chlorobenzoic Acid & $2 \mathrm{~g}$ \\
\hline
\end{tabular}

See Table 104.4 on the website for more information. 


\section{Spectrometry, Single Element Standard Solutions}

These SRMs are intended as standard solutions for calibrating instruments including atomic absorption spectrophotometry, inductively coupled plasma optical emission spectrometry, and inductively coupled plasma mass spectrometry. They can also be used in conjunction with any other analytical technique or procedure where standard solutions are required. Each SRM is a single element solution of $50 \mathrm{~mL}$ with a nominal concentration of $10 \mathrm{mg} / \mathrm{g}$. Each unit is provided in either a single high density polyethylene bottle or in $5 \times 10 \mathrm{~mL}$ borosilicate glass ampoules.

\begin{tabular}{|c|c|c|}
\hline SRM & Description & $\begin{array}{l}\text { Unit of } \\
\text { Issue }\end{array}$ \\
\hline 3101a & Aluminum (Al) Standard Solution & $5 \times 10 \mathrm{~mL}$ \\
\hline $3102 a$ & Antimony (Sb) Standard Solution & $50 \mathrm{~mL}$ \\
\hline $3103 a$ & Arsenic (As) Standard Solution & $5 \times 10 \mathrm{~mL}$ \\
\hline $3104 a$ & Barium (Ba) Standard Solution & $50 \mathrm{~mL}$ \\
\hline $3105 a$ & Beryllium (Be) Standard Solution & $5 \times 10 \mathrm{~mL}$ \\
\hline 3106 & Bismuth (Bi) Standard Solution & $5 \times 10 \mathrm{~mL}$ \\
\hline 3107 & Boron (B) Standard Solution & $50 \mathrm{~mL}$ \\
\hline 3108 & Cadmium (Cd) Standard Solution & $5 \times 10 \mathrm{~mL}$ \\
\hline $3109 a$ & Calcium (Ca) Standard Solution & $5 \times 10 \mathrm{~mL}$ \\
\hline 3110 & Cerium (Ce) Standard Solution & $5 \times 10 \mathrm{~mL}$ \\
\hline $3111 a$ & Cesium (Cs) Standard Solution & $5 \times 10 \mathrm{~mL}$ \\
\hline $3112 a$ & Chromium (Cr) Standard Solution & $5 \times 10 \mathrm{~mL}$ \\
\hline 3113 & Cobalt (Co) Standard Solution & $5 \times 10 \mathrm{~mL}$ \\
\hline 3114 & Copper $(\mathrm{Cu})$ Standard Solution & $50 \mathrm{~mL}$ \\
\hline $3115 a$ & Dysprosium (Dy) Standard Solution & $5 \times 10 \mathrm{~mL}$ \\
\hline $3116 a$ & Erbium (Er) Standard Solution & $5 \times 10 \mathrm{~mL}$ \\
\hline $3117 a$ & Europium $(\mathrm{Eu})$ Standard Solution & $5 \times 10 \mathrm{~mL}$ \\
\hline $3118 a$ & Gadolinium (Gd) Standard Solution & $5 \times 10 \mathrm{~mL}$ \\
\hline $3119 a$ & Gallium (Ga) Standard Solution & $5 \times 10 \mathrm{~mL}$ \\
\hline $3120 \mathrm{a}$ & Germanium (Ge) Standard Solution & $50 \mathrm{~mL}$ \\
\hline 3121 & Gold $(\mathrm{Au})$ Standard Solution & $5 \times 10 \mathrm{~mL}$ \\
\hline 3122 & Hafnium (Hf) Standard Solution & $50 \mathrm{~mL}$ \\
\hline $3123 a$ & Holmium (Ho) Standard Solution & $5 \times 10 \mathrm{~mL}$ \\
\hline $3124 a$ & Indium (In) Standard Solution & $5 \times 10 \mathrm{~mL}$ \\
\hline $3126 a$ & Iron $(\mathrm{Fe})$ Standard Solution & $5 \times 10 \mathrm{~mL}$ \\
\hline $3127 a$ & Lanthanum (La) Standard Solution & $5 \times 10 \mathrm{~mL}$ \\
\hline 3128 & Lead $(\mathrm{Pb})$ Standard Solution & $5 \times 10 \mathrm{~mL}$ \\
\hline $3129 a$ & Lithium (Li) Standard Solution & $5 \times 10 \mathrm{~mL}$ \\
\hline $3130 a$ & Lutetium (Lu) Standard Solution & $5 \times 10 \mathrm{~mL}$ \\
\hline 3131a & Magnesium (Mg) Standard Solution & $5 \times 10 \mathrm{~mL}$ \\
\hline
\end{tabular}

\begin{tabular}{|c|c|c|}
\hline SRM & Description & $\begin{array}{l}\text { Unit of } \\
\text { Issue }\end{array}$ \\
\hline 3132 & Manganese (Mn) Standard Solution & $5 \times 10 \mathrm{~mL}$ \\
\hline 3133 & Mercury (Hg) Standard Solution & $5 \times 10 \mathrm{~mL}$ \\
\hline 3134 & Molybdenum (Mo) Standard Solution & $5 \times 10 \mathrm{~mL}$ \\
\hline $3135 a$ & Neodymium (Nd) Standard Solution & $5 \times 10 \mathrm{~mL}$ \\
\hline 3136 & Nickel (Ni) Standard Solution & $5 \times 10 \mathrm{~mL}$ \\
\hline 3137 & Niobium $(\mathrm{Nb})$ Standard Solution & $50 \mathrm{~mL}$ \\
\hline 3138 & Palladium (Pd) Standard Solution & $5 \times 10 \mathrm{~mL}$ \\
\hline $3139 a$ & Phosphorus (P) Standard Solution & $5 \times 10 \mathrm{~mL}$ \\
\hline 3140 & Platinum (Pt) Standard Solution & $5 \times 10 \mathrm{~mL}$ \\
\hline $3141 \mathrm{a}$ & Potassium (K) Standard Solution & $5 \times 10 \mathrm{~mL}$ \\
\hline $3142 a$ & Praseodymium (Pr) Standard Solution & $5 \times 10 \mathrm{~mL}$ \\
\hline 3143 & Rhenium (Re) Standard Solution & $5 \times 10 \mathrm{~mL}$ \\
\hline 3144 & Rhodium (Rh) Standard Solution & $5 \times 10 \mathrm{~mL}$ \\
\hline $3145 a$ & Rubidium $(\mathrm{Rb})$ Standard Solution & $5 \times 10 \mathrm{~mL}$ \\
\hline $3147 \mathrm{a}$ & Samarium $(\mathrm{Sm})$ Standard Solution & $5 \times 10 \mathrm{~mL}$ \\
\hline $3148 a$ & Scandium (Sc) Standard Solution & $5 \times 10 \mathrm{~mL}$ \\
\hline 3149 & Selenium (Se) Standard Solution & $5 \times 10 \mathrm{~mL}$ \\
\hline 3150 & Silicon (Si) Standard Solution & $50 \mathrm{~mL}$ \\
\hline 3151 & Silver (Ag) Standard Solution & $5 \times 10 \mathrm{~mL}$ \\
\hline $3152 a$ & Sodium (Na) Standard Solution & $50 \mathrm{~mL}$ \\
\hline $3153 a$ & Strontium (Sr) Standard Solution & $5 \times 10 \mathrm{~mL}$ \\
\hline 3154 & Sulfur (S) Standard Solution & $5 \times 10 \mathrm{~mL}$ \\
\hline 3155 & Tantalum (Ta) Standard Solution & $50 \mathrm{~mL}$ \\
\hline 3156 & Tellurium $(\mathrm{Te})$ Standard Solution & $5 \times 10 \mathrm{~mL}$ \\
\hline $3157 \mathrm{a}$ & Terbium (Tb) Standard Solution & $5 \times 10 \mathrm{ml}$ \\
\hline 3158 & Thallium (Tl) Standard Solution & $5 \times 10 \mathrm{~mL}$ \\
\hline 3159 & Thorium (Th) Standard Solution & $50 \mathrm{~mL}$ \\
\hline $3160 a$ & Thulium (Tm) Standard Solution & $5 \times 10 \mathrm{~mL}$ \\
\hline $3161 \mathrm{a}$ & Tin (Sn) Standard Solution & $50 \mathrm{~mL}$ \\
\hline $3162 a$ & Titanium (Ti) Standard Solution & $50 \mathrm{~mL}$ \\
\hline 3163 & Tungsten (W) Standard Solution & $50 \mathrm{~mL}$ \\
\hline 3164 & Uranium (U) Standard Solution (Radioactive) & $5 \times 10 \mathrm{~mL}$ \\
\hline 3165 & Vanadium (V) Standard Solution & $5 \times 10 \mathrm{~mL}$ \\
\hline $3166 a$ & Ytterbium (Yb) Standard Solution & $5 \times 10 \mathrm{~mL}$ \\
\hline $3167 a$ & Yttrium (Y) Standard Solution & $5 \times 10 \mathrm{~mL}$ \\
\hline $3168 \mathrm{a}$ & Zinc (Zn) Standard Solution & $5 \times 10 \mathrm{~mL}$ \\
\hline 3169 & Zirconium (Zr) Standard Solution & $50 \mathrm{~mL}$ \\
\hline 3177 & Mercuric Chloride Standard Solution & $5 \times 10 \mathrm{~mL}$ \\
\hline
\end{tabular}

See Table 104.5 on the website for more information. 


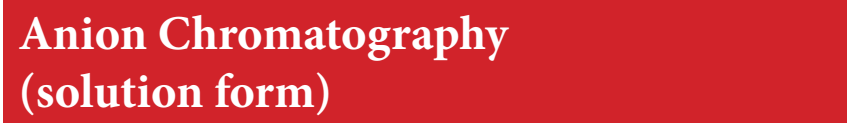

These SRMs are single component solutions prepared gravimetrically for use in anion chromatography or any other technique that requires aqueous standard solutions for calibration or control materials.

\begin{tabular}{|l|l|c|}
\hline SRM & Description & $\begin{array}{c}\text { Unit of } \\
\text { Issue }\end{array}$ \\
\hline $\mathbf{3 1 8 0}$ & Iodide Anion $\left(\mathrm{I}^{-}\right)$Standard Solution & $5 \times 5 \mathrm{~mL}$ \\
\hline $\mathbf{3 1 8 1}$ & Sulfate Anion $\left(\mathrm{SO}_{4}{ }^{2-}\right)$ Standard Solution & $5 \times 10 \mathrm{~mL}$ \\
\hline $\mathbf{3 1 8 2}$ & Chloride Anion $(\mathrm{Cl})$ Standard Solution & $5 \times 10 \mathrm{~mL}$ \\
\hline $\mathbf{3 1 8 3}$ & Fluoride Anion $(\mathrm{F})$ Standard Solution & $50 \mathrm{~mL}$ \\
\hline $\mathbf{3 1 8 4}$ & Bromide Anion $\left(\mathrm{Br}^{-}\right)$Standard Solution & $5 \times 10 \mathrm{~mL}$ \\
\hline $\mathbf{3 1 8 5}$ & Nitrate Anion $\left(\mathrm{NO}_{3}{ }^{-}\right)$Standard Solution & $5 \times 10 \mathrm{~mL}$ \\
\hline $\mathbf{3 1 8 6}$ & Phosphate Anion $\left(\mathrm{PO}_{4}{ }^{3-}\right)$ Standard Solution & $5 \times 10 \mathrm{~mL}$ \\
\hline
\end{tabular}

See Table 104.8 on the website for more information.

\section{Stable Isotopic Materials (solid and solution forms)}

The isotopic composition of these SRMs has been determined by mass spectrometry.

For light stable isotopic materials value assigned on an artifact based scale, see Light Stable Isotopic Materials

\begin{tabular}{|l|l|c|}
\hline SRM & Description & $\begin{array}{c}\text { Unit of } \\
\text { Issue }\end{array}$ \\
\hline $\mathbf{9 5 1 a}$ & Boric Acid Isotopic Standard & $10 \mathrm{~g}$ \\
\hline $\mathbf{9 5 2}$ & Enriched Boric Acid Standard & $0.25 \mathrm{~g}$ \\
\hline $\mathbf{9 7 3}$ & Boric Acid Acidimetric Standard & $100 \mathrm{~g}$ \\
\hline $\mathbf{9 7 5 a}$ & Isotopic Standard for Chlorine & $0.25 \mathrm{~g}$ \\
\hline $\mathbf{9 7 7}$ & Isotopic Standard for Bromine & $0.25 \mathrm{~g}$ \\
\hline $\mathbf{9 7 8 a}$ & Assay-Isotopic Standard for Silver & $0.25 \mathrm{~g}$ \\
\hline $\mathbf{9 7 9}$ & Chromium Isotopic Standard & $0.25 \mathrm{~g}$ \\
\hline $\mathbf{9 8 0}$ & Isotopic Standard for Magnesium & $0.25 \mathrm{~g}$ \\
\hline $\mathbf{9 8 1}$ & Common Lead Isotopic Standard (wire) & $1 \mathrm{~g}$ \\
\hline $\mathbf{9 8 2}$ & Equal-Atom Lead Isotopic Standard (wire) & $1 \mathrm{~g}$ \\
\hline $\mathbf{9 8 3}$ & Radiogenic Lead Isotopic Standard (wire) & $1 \mathrm{~g}$ \\
\hline $\mathbf{9 8 4}$ & Rubidium Chloride & $0.25 \mathrm{~g}$ \\
\hline $\mathbf{9 8 6}$ & Isotopic Standard for Nickel & $0.5 \mathrm{~g}$ \\
\hline $\mathbf{9 8 7}$ & Strontium Carbonate Isotopic Standard & $1 \mathrm{~g}$ \\
\hline $\mathbf{9 9 4}$ & Isotopic Standard for Gallium & $0.25 \mathrm{~g}$ \\
\hline $\mathbf{9 9 7}$ & Thallium Isotopic Standard & $0.25 \mathrm{~g}$ \\
\hline $\mathbf{8 5 9 9}$ & Henderson Molybdenite & $10 \mathrm{~g}$ \\
\hline $\mathbf{9 2}$ & & \\
\hline
\end{tabular}

See Table 104.9 on the website for more information.

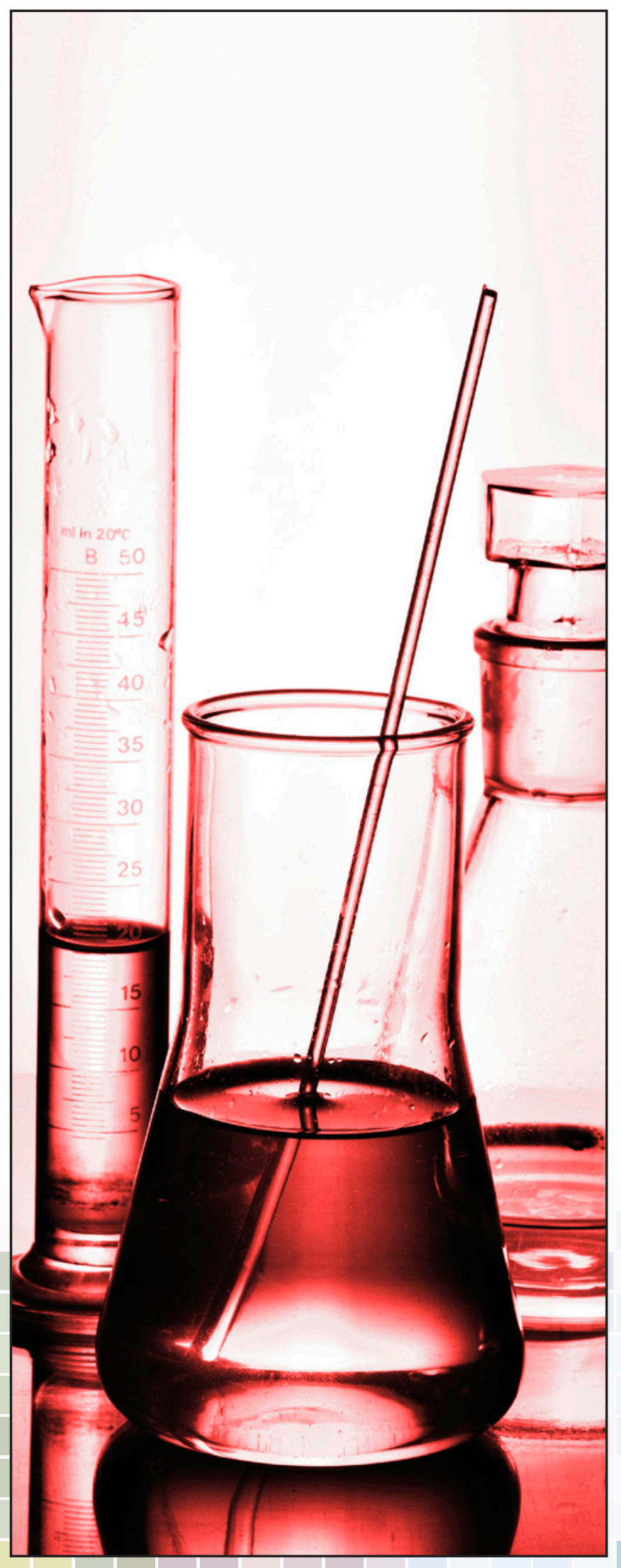




\section{Light Stable Isotopic Materials (gas, liquid, and solid forms)}

These RMs are for calibration of isotope-ratio mass spectrometers and associated sample preparation systems. They are distributed by NIST on behalf of the International Atomic Energy Agency (IAEA). At the request of the IAEA, quantities of these materials are limited to one unit of each RM per laboratory every 3 years.

The isotopic compositions are given in parts per thousand difference from isotope-ratio standards-Hydrogen and oxygen: Vienna Standard Mean Ocean Water (VSMOW), Carbon: Vienna PeeDee Belemnite (VPDB), Nitrogen: atmospheric $\mathrm{N}_{2}$ (Air), Silicon: NBS28 Silica Sand (optical), and Sulfur: Vienna Canyon Diablo Troilite (VCDT). In RM 8545 (LSVEC) is also expressed as an absolute isotopic ratio.

\begin{tabular}{|c|c|c|}
\hline SRM & Description & $\begin{array}{l}\text { Unit of } \\
\text { Issue }\end{array}$ \\
\hline 8529 & IAEA-S-3 (Sulfur Isotopes in Silver Sulfide) & $1 \times 0.5 \mathrm{~g}$ \\
\hline $8535 a$ & $\begin{array}{l}\text { VSMOW2 Vienna Standard Mean Ocean Water } \\
\text { (Hydrogen and Oxyen Isotopes in Water) }\end{array}$ & $20 \mathrm{~mL}$ \\
\hline 8536 & GISP-Water & $20 \mathrm{~mL}$ \\
\hline 8537 & SLAP-Water Light Stable Isotopic Standard & $20 \mathrm{~mL}$ \\
\hline 8539 & $\begin{array}{l}\text { NBS22 Oil } \\
\text { (Carbon and Hydrogen Isotopes in Oil) }\end{array}$ & $1 \mathrm{~mL}$ \\
\hline 8540 & $\begin{array}{l}\text { IAEA-CH-7 } \\
\text { (Carbon and Hydrogen Isotopes } \\
\text { in Polyethylene Foil) }\end{array}$ & $3.5 \mathrm{~g}$ \\
\hline 8541 & $\begin{array}{l}\text { USGS24 Graphite } \\
\text { (Carbon Isotopes in Graphite) }\end{array}$ & $0.8 \mathrm{~g}$ \\
\hline 8542 & $\begin{array}{l}\text { IAEA-CH-6 Sucrose } \\
\text { (Carbon Isotopes in Sucrose) }\end{array}$ & $1 \mathrm{~g}$ \\
\hline 8543 & NBS 18 (Carbon Isotopes in Carbonatite) & $0.4 \mathrm{~g}$ \\
\hline 8544 & $\begin{array}{l}\text { NBS } 19 \text { Limestone } \\
\text { (Carbon and Oxygen Isotopes in Carbonate) }\end{array}$ & $0.4 \mathrm{~g}$ \\
\hline 8545 & $\begin{array}{l}\text { LSVEC (Carbon, Oxygen, and Lithium } \\
\text { Isotopes in Lithium Carbonate) }\end{array}$ & $0.4 \mathrm{~g}$ \\
\hline 8546 & $\begin{array}{l}\text { NBS28 } \\
\text { (Silicon and Oxygen Isotopes in Silica Sand) }\end{array}$ & $0.4 \mathrm{~g}$ \\
\hline 8547 & $\begin{array}{l}\text { IAEA-N-1 } \\
\text { (Nitrogen Isotopes in Ammonium Sulfate) }\end{array}$ & $0.4 \mathrm{~g}$ \\
\hline 8548 & $\begin{array}{l}\text { IAEA-N-2 } \\
\text { (Nitrogen Isotopes in Ammonium Sulfate) }\end{array}$ & $0.4 \mathrm{~g}$ \\
\hline 8550 & $\begin{array}{l}\text { USGS25 } \\
\text { (Nitrogen Isotopes in Ammonium Sulfate) }\end{array}$ & $0.5 \mathrm{~g}$ \\
\hline
\end{tabular}

\begin{tabular}{|c|c|c|}
\hline SRM & Description & $\begin{array}{l}\text { Unit of } \\
\text { Issue }\end{array}$ \\
\hline 8551 & $\begin{array}{l}\text { USGS26 } \\
\text { (Nitrogen Isotopes in Ammonium Sulfate) }\end{array}$ & $0.5 \mathrm{~g}$ \\
\hline 8552 & $\begin{array}{l}\text { NSVEC } \\
\text { (Nitrogen Isotopes in Gaseous Nitrogen) }\end{array}$ & $300 \mu \mathrm{mol}$ \\
\hline 8553 & $\begin{array}{l}\text { IAEA-S-4 (Soufre De Lacq) } \\
\text { (Sulfur Isotopes in Elemental Sulfur) }\end{array}$ & $0.5 \mathrm{~g}$ \\
\hline 8554 & IAEA-S-1 (Sulfur Isotopes in Silver Sulfide) & $0.5 \mathrm{~g}$ \\
\hline 8555 & IAEA-S-2 (Sulfur Isotopes in Silver Sulfide) & $0.5 \mathrm{~g}$ \\
\hline 8556 & NBS123 (Sulfur Isotopes in Sphalerite) & $1.5 \mathrm{~g}$ \\
\hline 8557 & $\begin{array}{l}\text { NBS127 } \\
\text { (Sulfur and Oxygen Isotopes in Barium Sulfate) }\end{array}$ & $0.5 \mathrm{~g}$ \\
\hline 8558 & $\begin{array}{l}\text { USGS32 } \\
\text { (Nitrogen and Oxygen Isotopes in Nitrate) }\end{array}$ & $0.9 \mathrm{~g}$ \\
\hline 8562 & $\begin{array}{l}\mathrm{CO}_{2} \text {-Heavy, Paleomarine Origin } \\
\text { (Carbon Dioxide) }\end{array}$ & set $(2)$ \\
\hline 8563 & $\begin{array}{l}\mathrm{CO}_{2} \text {-Light, Petrochemical Origin } \\
\text { (Carbon Dioxide) }\end{array}$ & set $(2)$ \\
\hline 8564 & $\begin{array}{l}\mathrm{CO}_{2} \text {-Biogenic, Modern Biomass Origin } \\
\text { (Carbon Dioxide) }\end{array}$ & set $(2)$ \\
\hline 8568 & $\begin{array}{l}\text { USGS34 Nitrogen and Oxygen Isotopes } \\
\text { in Nitrate }\end{array}$ & $0.9 \mathrm{~g}$ \\
\hline 8569 & $\begin{array}{l}\text { USGS35 Nitrogen and Oxygen Isotopes } \\
\text { in Nitrate }\end{array}$ & $0.9 \mathrm{~g}$ \\
\hline 8573 & $\begin{array}{l}\text { L-glutamic Acid USGS40(Light Carbon } \\
\text { and Nitrogen Isotopes in L-glutamic Acid) }\end{array}$ & $1 \mathrm{~g}$ \\
\hline 8574 & $\begin{array}{l}\text { L-glutamic Acid USGS41 (Heavy Carbon } \\
\text { and Nitrogen Isotopes in L-glutamic Acid) }\end{array}$ & $0.5 \mathrm{~g}$ \\
\hline
\end{tabular}

See Table 104.10 on the website for more information. 


\section{NIST 2018 SRM EXHIBIT SCHEDULE}

Pittsburgh Conference (PITTCON)

Booth \#3019

February 27 - March 1, 2018

Orange County Convention Center

Orlando, FL

American Chemical Society Spring Meeting (ACS)

March 18-20, 2018

Ernest N. Morial Convention Center

New Orleans, LA

AACC Meeting \& Clinical Lab Exposition

(AACC)

July 31 - August 2, 2018

McCormick Place Convention Center

Chicago, IL
American Chemical Society Fall Meeting (ACS)

Hynes Convention Center

August 19-21, 2018

Boston, MA

AOAC Annual Meeting \& Exposition (AOAC) Sheraton Centre Hotel

August 26-29, 2018

Toronto, CANADA

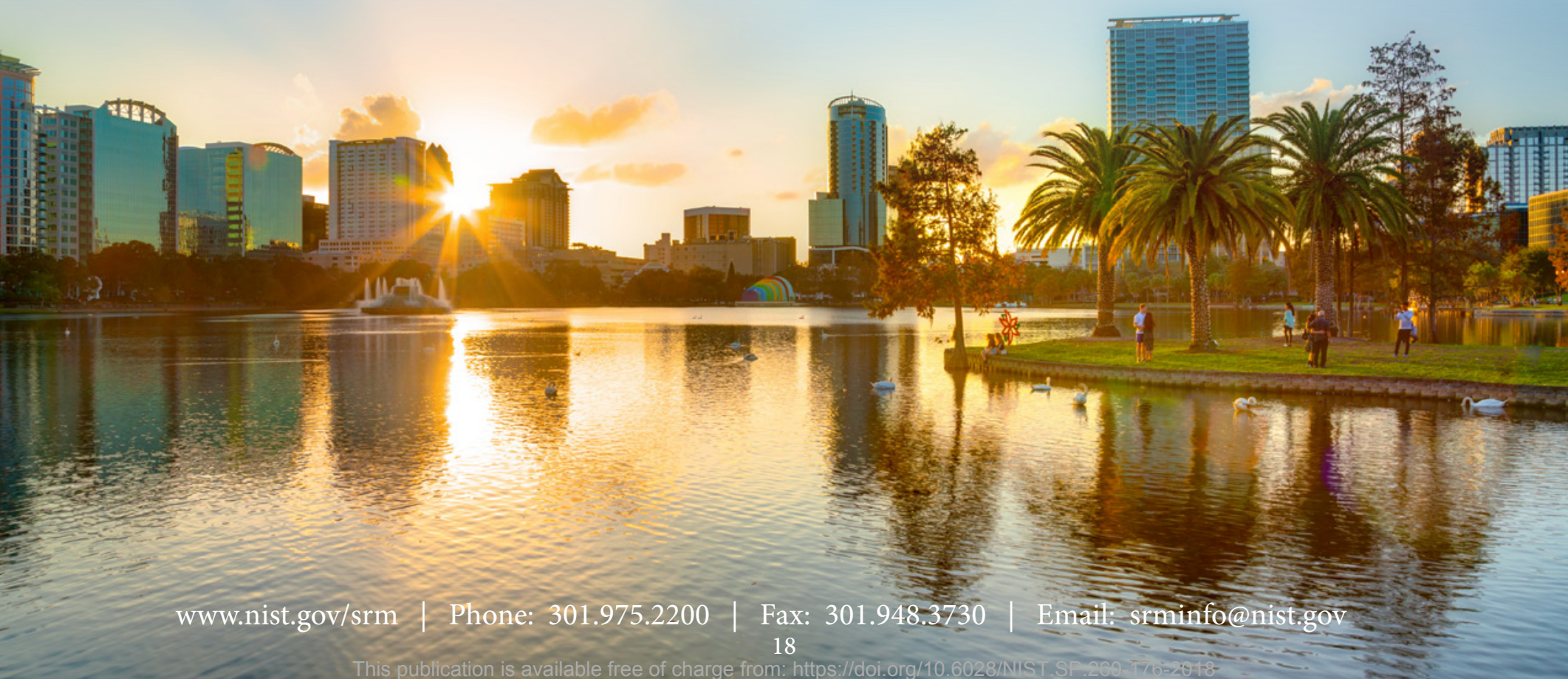




\section{Standard Reference Materials for Chemical Composition Health \& Industrial Hygiene}

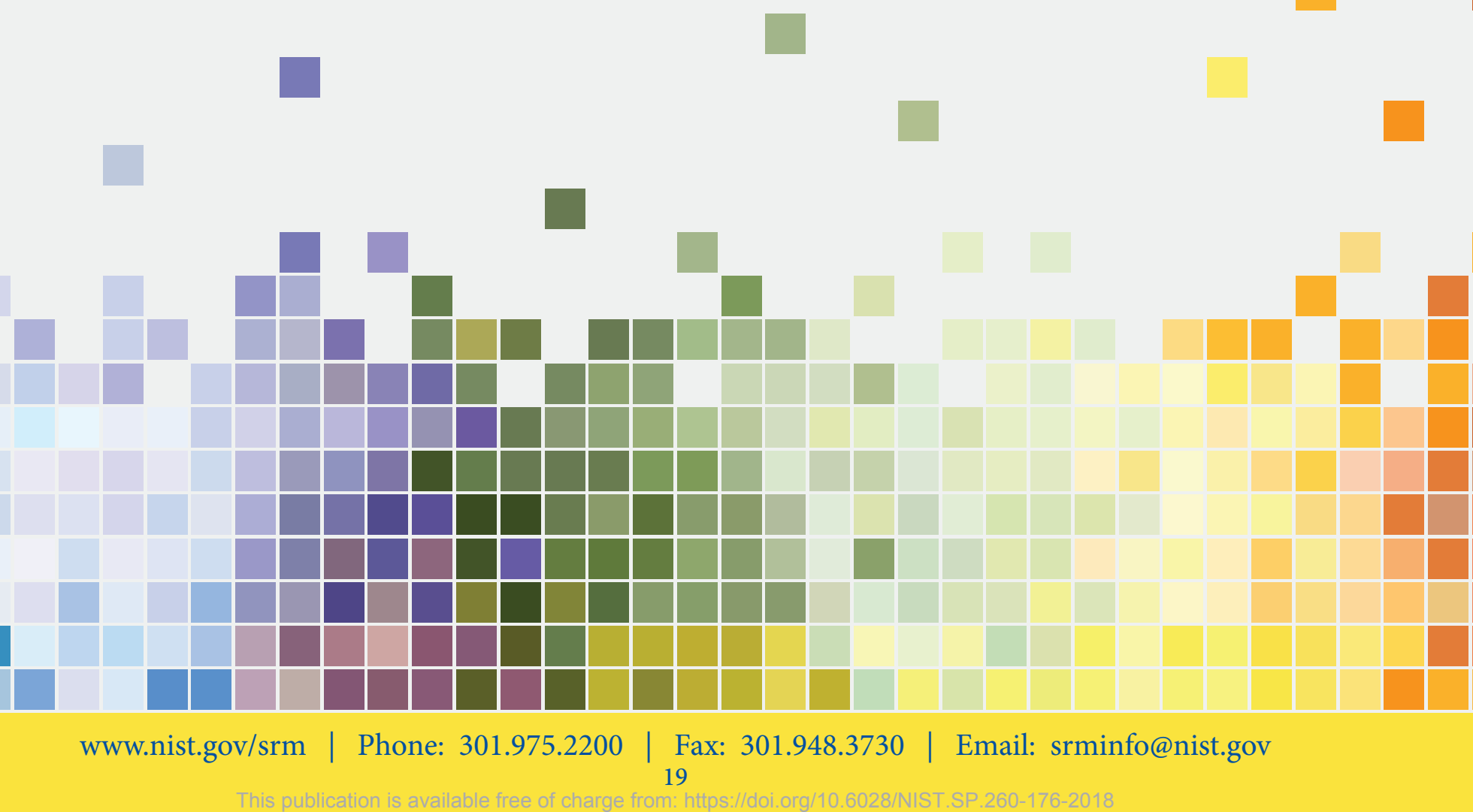




\section{Clinical Laboratory Materials (gas, liquid, and solid forms)}

The following SRMs are for calibrating apparatus and validating analytical methods used in clinical and pathology laboratories. Additional information on the serum materials is given in table Serum and Plasma Materials.

\begin{tabular}{|c|c|c|}
\hline SRM & Description & $\begin{array}{l}\text { Unit of } \\
\text { Issue }\end{array}$ \\
\hline $900 a$ & Antiepilepsy Drugs in Frozen Human Serum & 4 vials \\
\hline $909 c$ & Frozen Human Serum & $3 \times 2 \mathrm{~mL}$ \\
\hline $911 \mathrm{c}$ & Cholesterol & $2 \mathrm{~g}$ \\
\hline $912 a$ & Urea-Clinical & $25 \mathrm{~g}$ \\
\hline $913 b$ & Uric Acid & $10 \mathrm{~g}$ \\
\hline $914 a$ & Creatinine & $10 \mathrm{~g}$ \\
\hline $915 b$ & Calcium Carbonate (Clinical Standard) & $20 \mathrm{~g}$ \\
\hline $916 a$ & Bilirubin & $100 \mathrm{mg}$ \\
\hline $917 \mathrm{c}$ & D-Glucose (Dextrose) & $50 \mathrm{~g}$ \\
\hline $918 \mathrm{c}$ & Potassium Chloride (Clinical) & $30 \mathrm{~g}$ \\
\hline $919 b$ & Sodium Chloride (Clinical) & $30 \mathrm{~g}$ \\
\hline 920 & D-Mannitol & $50 \mathrm{~g}$ \\
\hline 921 & Cortisol (Hydrocortisone) & $1 \mathrm{~g}$ \\
\hline $924 a$ & Lithium Carbonate & $30 \mathrm{~g}$ \\
\hline $927 \mathrm{e}$ & $\begin{array}{l}\text { Bovine Serum Albumin (7 \%, solution) } \\
\text { (Total Protein Solution) }\end{array}$ & $10 \times 2.2 \mathrm{~mL}$ \\
\hline 928 & Lead Nitrate (Clinical) & $30 \mathrm{~g}$ \\
\hline $929 a$ & Magnesium Gluconate & $5 \mathrm{~g}$ \\
\hline 937 & Iron Metal (Clinical Standard) & $50 \mathrm{~g}$ \\
\hline $955 \mathrm{c}$ & Toxic Metals in Caprine Blood & 4 vials \\
\hline 956d & Electrolytes in Frozen Human Serum & $6 \times 2.0 \mathrm{~mL}$ \\
\hline $965 b$ & Glucose in Frozen Human Serum & set $(8)$ \\
\hline $967 a$ & Creatinine in Frozen Human Serum & $\operatorname{set}(4)$ \\
\hline $968 \mathrm{e}$ & $\begin{array}{l}\text { Fat-Soluble Vitamins, Carotenoids, and } \\
\text { Cholesterol in Human Serum }\end{array}$ & set (3) \\
\hline 971 & Hormones in Frozen Human Serum & $2 \times 5 \mathrm{~mL}$ \\
\hline $972 a$ & $\begin{array}{l}\text { Vitamin D Metabolites in Frozen } \\
\text { Human Serum }\end{array}$ & $4 \times 1 \mathrm{~mL}$ \\
\hline 998 & Angiotensin I (Human) & $0.5 \mathrm{mg}$ \\
\hline 1400 & Bone Ash & $50 \mathrm{~g}$ \\
\hline 1486 & Bone Meal & $50 \mathrm{~g}$ \\
\hline 1595 & Tripalmitin & $2 \mathrm{~g}$ \\
\hline $1598 \mathrm{a}$ & Inorganic Constituents in Animal Serum & 2 vials \\
\hline 1599 & Anticonvulsant Drug Level Assay Standard & set (4) \\
\hline 1950 & Metabolites in Human Plasma & $5 \times 1 \mathrm{~mL}$ \\
\hline $1951 c$ & Lipids in Frozen Human Serum & 4 vials \\
\hline $1952 a$ & Cholesterol in Human Serum & $\operatorname{set}(6)$ \\
\hline
\end{tabular}

www.nist.gov/srm | Phone: 301.975.2200

\begin{tabular}{|c|c|c|}
\hline SRM & Description & $\begin{array}{l}\text { Unit of } \\
\text { Issue }\end{array}$ \\
\hline $2366 a$ & $\begin{array}{l}\text { Cytomegalovirus DNA (Towne } \triangle 147 \text { BAC) } \\
\text { for DNA Measurements }\end{array}$ & 1 vial \\
\hline 2378 & Fatty Acids in Frozen Human Serum & 3 vials \\
\hline $2389 a$ & Amino Acids in $0.1 \mathrm{~mol} / \mathrm{L}$ Hydrochloric Acid & $5 \times 1.2 \mathrm{~mL}$ \\
\hline 2668 & Toxic Elements in Frozen Human Urine & set (10) \\
\hline 2669 & Arsenic Species in Frozen Human Urine & set $(10)$ \\
\hline $2670 a$ & Toxic Elements in Urine (Freeze-Dried) & sets $(4)$ \\
\hline 2921 & Human Cardiac Troponin Complex & $5 \times 115 \mu \mathrm{L}$ \\
\hline 2924 & C-Reactive Protein Solution & $3 \times 1 \mathrm{~mL}$ \\
\hline $2972 a$ & 25-Hydroxyvitamin D Calibration Solutions & $20 \times 1.2 \mathrm{~mL}$ \\
\hline 2973 & $\begin{array}{l}\text { Vitamin D Metabolites } \\
\text { in Frozen Human Serum (High Level) }\end{array}$ & 1 vial \\
\hline 3667 & Creatinine in Frozen Human Urine & $10 \mathrm{~mL}$ \\
\hline 3668 & $\begin{array}{l}\text { Mercury, Perchlorate, and Iodide in Frozen } \\
\text { Human Urine }\end{array}$ & set $(10)$ \\
\hline 3669 & $\begin{array}{l}\text { Arsenic Species in Frozen Human } \\
\text { Urine (Elevated Levels) }\end{array}$ & $5 \times 1.5 \mathrm{~mL}$ \\
\hline 3671 & $\begin{array}{l}\text { Nicotine Metabolites in Human } \\
\text { Urine (Frozen) }\end{array}$ & $3 \times 10 \mathrm{~mL}$ \\
\hline 3672 & $\begin{array}{l}\text { Organic Contaminants in Smokers' } \\
\text { Urine (Frozen) }\end{array}$ & $5 \times 10 \mathrm{~mL}$ \\
\hline 3673 & $\begin{array}{l}\text { Organic Contaminants in Non-Smokers' } \\
\text { Urine (Frozen) }\end{array}$ & $5 \times 10 \mathrm{~mL}$ \\
\hline 3950 & Vitamin $B_{6}$ in Frozen Human Serum & 2 vials \\
\hline 8321 & Peptide Mixture of Proteomics & 3 vials \\
\hline 8323 & Yeast Protein Extract & $3 \times 0.2 \mathrm{~mL}$ \\
\hline 8327 & $\begin{array}{l}\text { Peptide Reference Material for Molecular } \\
\text { Mass and Purity Measurements }\end{array}$ & $\operatorname{set}(3)$ \\
\hline $8642 a$ & FDA Saxitoxin Dihydrochloride Solution & $10 \times 1.2 \mathrm{~mL}$ \\
\hline 8671 & $\begin{array}{l}\text { NISTmAb, Humanized IgG1к } \\
\text { Monoclonal Antibody }\end{array}$ & $800 \mu \mathrm{L}$ \\
\hline
\end{tabular}

See Table 105.1 on the website for more information.

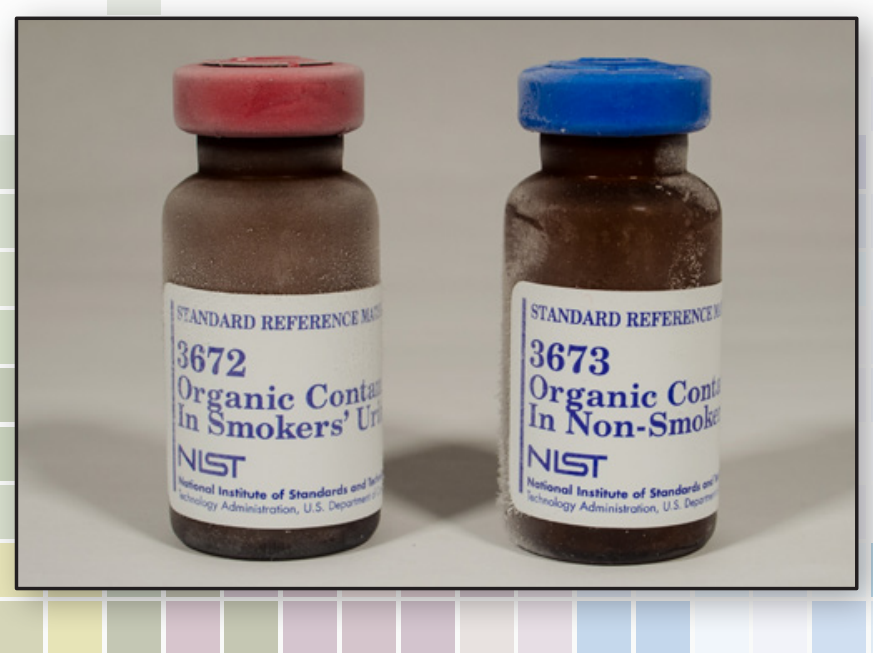

Fax: 301.948.3730 | Email: srminfo@nist.gov 


\section{Serum and Plasma Materials (frozen, liquid, and lyophilized forms)}

These SRMs serve a variety of clinical measurement needs.

SRMs 1957 and 1958 are freeze-dried human sera for evaluating PCB congeners, chlorinated pesticides, and PBDE congeners with non-certified values for PFCs and dioxins and furans.

\begin{tabular}{|l|l|c|}
\hline SRM & Description & $\begin{array}{c}\text { Unit of } \\
\text { Issue }\end{array}$ \\
\hline $\mathbf{9 0 9 c}$ & Frozen Human Serum & $3 \times 2 \mathrm{~mL}$ \\
\hline $\mathbf{9 2 7 e}$ & $\begin{array}{l}\text { Bovine Serum Albumin (7 \%, solution) } \\
\text { (Total Protein Solution) }\end{array}$ & $10 \times 2.2 \mathrm{~mL}$ \\
\hline $\mathbf{9 5 6 d}$ & Electrolytes in Frozen Human Serum & $6 \times 2.0 \mathrm{~mL}$ \\
\hline $\mathbf{9 6 5 b}$ & Glucose in Frozen Human Serum & set $(8)$ \\
\hline $\mathbf{9 6 7 a}$ & Creatinine in Frozen Human Serum & $\operatorname{set}(4)$ \\
\hline $\mathbf{9 6 8 e}$ & $\begin{array}{l}\text { Fat-Soluble Vitamins, Carotenoids, } \\
\text { and Cholesterol in Human Serum }\end{array}$ & set $(3)$ \\
\hline $\mathbf{9 7 1}$ & Hormones in Frozen Human Serum & $2 \times 5 \mathrm{~mL}$ \\
\hline $\mathbf{9 7 2 a}$ & $\begin{array}{l}\text { Vitamin D Metabolites in } \\
\text { Frozen Human Serum }\end{array}$ & $4 \times 1 \mathrm{~mL}$ \\
\hline $\mathbf{1 9 5 0}$ & Metabolites in Human Plasma & $5 \times 1 \mathrm{~mL}$ \\
\hline $\mathbf{1 9 5 1 c}$ & Lipids in Frozen Human Serum & 4 vials \\
\hline $\mathbf{1 9 5 2 a}$ & Cholesterol in Human Serum & set $(6)$ \\
\hline $\mathbf{1 9 5 7}$ & $\begin{array}{l}\text { Organic Contaminants in } \\
\text { Non-Fortified Human Serum }\end{array}$ & $5 \times 10 \mathrm{~mL}$ \\
\hline $\mathbf{1 9 5 8}$ & $\begin{array}{l}\text { Organic Contaminants in } \\
\text { Fortified Human Serum }\end{array}$ & $5 \times 10 \mathrm{~mL}$ \\
\hline $\mathbf{2 3 7 8}$ & Fatty Acids in Frozen Human Serum & $3 \times 1 \mathrm{~mL}$ \\
\hline $\mathbf{2 9 2 1}$ & Human Cardiac Troponin Complex & $5 \times 115 \mu \mathrm{vial}$ \\
\hline $\mathbf{2 9 7 3}$ & $\begin{array}{l}\text { Vitamin D Metabolites } \\
\text { in Frozen Human Serum (High Level) }\end{array}$ \\
\hline $\mathbf{3 9 5 0}$ & Vitamin B6 in Frozen Human Serum & 2 vials \\
\hline
\end{tabular}

See Table 105.2 on the website for more information.

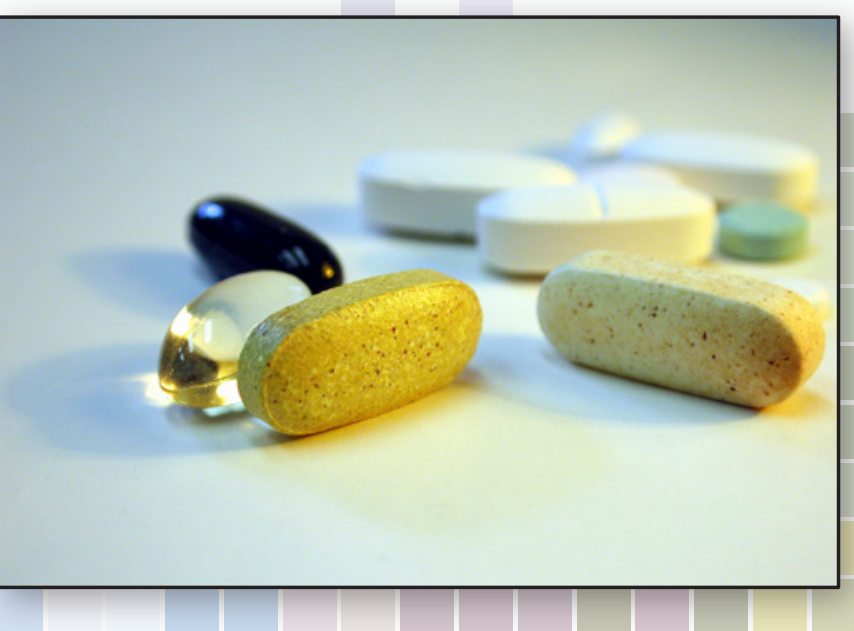

\section{Ethanol Solutions}

These SRMs are for use in the calibration of instruments and techniques for the determination of ethanol (ethyl alcohol) in breath and blood. SRM 1828a consists of four concentrations of ethanol-water solutions in a set of five ampoules.

\begin{tabular}{|c|c|c|}
\hline SRM & Description & $\begin{array}{l}\text { Unit of } \\
\text { Issue }\end{array}$ \\
\hline $1828 b$ & $\begin{array}{l}\text { Ethanol-Water Solutions } \\
\text { (Nominal Mass Fractions of } 0.02 \%, 0.04 \% \text {, } \\
0.08 \%, 0.1 \%, 0.2 \% \text {, and } 0.3 \% \text {, }\end{array}$ & $6 \times 1.2 \mathrm{~mL}$ \\
\hline 2891 & $\begin{array}{l}\text { Ethanol-Water Solution } \\
\text { (Nominal Mass Fraction } 0.02 \% \text { ) }\end{array}$ & $5 \times 1.2 \mathrm{~mL}$ \\
\hline 2892 & $\begin{array}{l}\text { Ethanol-Water Solution } \\
\text { (Nominal Mass Fraction } 0.04 \% \text { ) }\end{array}$ & $5 \times 1.2 \mathrm{~mL}$ \\
\hline 2893 & $\begin{array}{l}\text { Ethanol-Water Solution } \\
\text { (Nominal Mass Fraction } 0.08 \% \text { ) }\end{array}$ & $5 \times 1.2 \mathrm{~mL}$ \\
\hline 2894 & $\begin{array}{l}\text { Ethanol-Water Solution } \\
\text { (Nominal Mass Fraction } 0.1 \% \text { ) }\end{array}$ & $5 \times 1.2 \mathrm{~mL}$ \\
\hline 2895 & $\begin{array}{l}\text { Ethanol-Water Solution } \\
\text { (Nominal Mass Fraction } 0.2 \% \text { ) }\end{array}$ & $5 \times 1.2 \mathrm{~mL}$ \\
\hline 2896 & $\begin{array}{l}\text { Ethanol-Water Solution } \\
\text { (Nominal Mass Fraction } 0.3 \% \text { ) }\end{array}$ & $5 \times 1.2 \mathrm{~mL}$ \\
\hline $2897 a$ & $\begin{array}{l}\text { Ethanol Water Solution } \\
\text { (Nominal Mass Fraction } 2 \% \text { ) }\end{array}$ & $5 \times 10 \mathrm{~mL}$ \\
\hline $2898 a$ & $\begin{array}{l}\text { Ethanol Water Solution } \\
\text { (Nominal Mass Fraction } 6 \% \text { ) }\end{array}$ & $5 \times 10 \mathrm{~mL}$ \\
\hline 2899a & $\begin{array}{l}\text { Ethanol-Water Solution } \\
\text { (Nominal Mass Fraction } 25 \% \text { ) }\end{array}$ & $5 \times 10 \mathrm{~mL}$ \\
\hline 2900 & $\begin{array}{l}\text { Ethanol-Water Solution } \\
\text { (Nominal Mass Fraction 95.6\%) }\end{array}$ & $5 \times 10 \mathrm{~mL}$ \\
\hline
\end{tabular}

See Table 105.3 on the website for more information.

\section{Toxic Substances in Urine (powder and frozen form)}

SRM 2669 is for determination of arsenic species in human urine. A unit consists of five pouches, each containing one vial of Level I Arsenic Species and one vial of Level II Arsenic Species.

\begin{tabular}{|l|l|c|}
\hline SRM & Description & $\begin{array}{c}\text { Unit of } \\
\text { Issue }\end{array}$ \\
\hline $\mathbf{2 6 6 8}$ & Toxic Elements in Frozen Human Urine & set (10) \\
\hline $\mathbf{2 6 6 9}$ & Arsenic Species in Frozen Human Urine & set (10) \\
\hline $\mathbf{2 6 7 0 a}$ & Toxic Elements in Urine (Freeze-Dried) & set (4) \\
\hline $\mathbf{3 6 6 8}$ & $\begin{array}{l}\text { Mercury, Perchlorate, and Iodide } \\
\text { in Frozen Human Urine }\end{array}$ & set (10) \\
\hline $\mathbf{3 6 6 9}$ & $\begin{array}{l}\text { Arsenic Species in Frozen Human } \\
\text { Urine (Elevated Levels) }\end{array}$ & set (5) \\
\hline
\end{tabular}

See Table 105.4 on the website for more information. 


\section{Drugs of Abuse}

\section{(hair, serum, and urine)}

\begin{tabular}{|l|l|c|}
\hline SRM & Description & $\begin{array}{c}\text { Unit of } \\
\text { Issue }\end{array}$ \\
\hline $\mathbf{1 5 0 7 b}$ & THC-COOH in Freeze-Dried Urine & set (3) \\
\hline $\mathbf{1 5 0 8 a}$ & $\begin{array}{l}\text { Benzoylecgonine (Cocaine Metabolite) } \\
\text { in Freeze-Dried Urine }\end{array}$ & set (4) \\
\hline
\end{tabular}

See Table 105.7 on the website for more information.

\section{Biomaterials (solid forms)}

Biomaterials are found in medical devices that are in intimate contact with tissues and body fliuds.

\begin{tabular}{|l|l|c|}
\hline SRM & Description & $\begin{array}{c}\text { Unit of } \\
\text { Issue }\end{array}$ \\
\hline $\mathbf{2 9 1 0 b}$ & Hydroxyapatite & $2 \mathrm{~g}$ \\
\hline $\mathbf{8 0 1 1}$ & $\begin{array}{l}\text { Gold Nanoparticles, } \\
\text { Nominal 10 nm Diameter }\end{array}$ & $2 \times 5 \mathrm{~mL}$ \\
\hline $\mathbf{8 0 1 2}$ & $\begin{array}{l}\text { Gold Nanoparticles, } \\
\text { Nominal 30 nm Diameter }\end{array}$ & $2 \times 5 \mathrm{~mL}$ \\
\hline $\mathbf{8 0 1 3}$ & $\begin{array}{l}\text { Gold Nanoparticles, } \\
\text { Nominal 60 nm Diameter }\end{array}$ & $2 \times 5 \mathrm{~mL}$ \\
\hline $\mathbf{8 3 9 4}$ & $\begin{array}{l}\text { Tissue Engineering Reference Scaffolds } \\
\text { for Cell Culture }\end{array}$ & 24 scaffolds \\
\hline
\end{tabular}

See Table 105.9 on the website for more information.

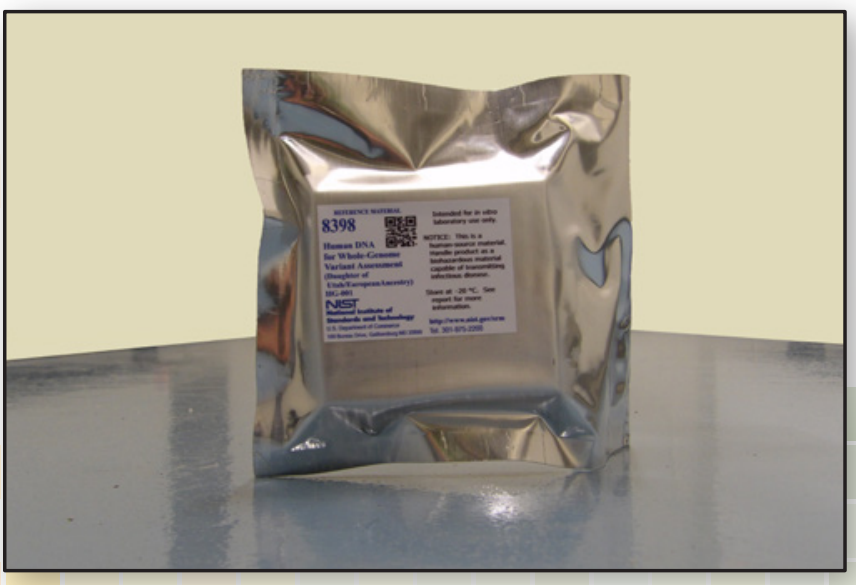

\section{Respirable Materials on Filter Media}

These SRMs enable the determination of hazardous materials potentially found in industrial environments. SRMs 2676d, 2677a, and 3087a have been superseded by SRM 2783 Air Particulate on Filter Media.

\begin{tabular}{|l|l|c|}
\hline SRM & Description & $\begin{array}{c}\text { Unit of } \\
\text { Issue }\end{array}$ \\
\hline $\mathbf{2 6 8 1}$ & $\begin{array}{l}\text { Trace Constituent Elements in Blank } \\
\text { Filters (47 mm dia) }\end{array}$ & 10 filters \\
\hline $\mathbf{2 7 8 3}$ & $\begin{array}{l}\text { Air Particulate on Filter Media } \\
(47 \text { mm dia) }\end{array}$ & $2+2$ Blank \\
\hline 2950a & $\begin{array}{l}\text { Respirable Alpha Quartz on Filter Media } \\
\text { (Nominal Mass of Alpha Quartz } 5 \mu \mathrm{g}-\end{array}$ & $\begin{array}{c}35 \text { filters } \\
\text { plus } 35 \\
\text { blanks }\end{array}$ \\
\hline $\mathbf{2 9 6 0} \mu$ & $\begin{array}{l}\text { Respirable Cristobalite on Filter Media } \\
(\text { Nominal Mass of Cristobalite: } 5 \mu \mathrm{g}-250 \mu \mathrm{g})\end{array}$ & $\begin{array}{c}30 \text { filters } \\
\text { plus 30 } \\
\text { blanks }\end{array}$ \\
\hline $\mathbf{8 7 8 5}$ & Air Particulate Matter on Filter Media & 3 filters \\
\hline $\mathbf{8 7 8 6}$ & Filter Blank for RM 8785 & filter \\
\hline
\end{tabular}

See Table 105.10 on the website for more information.

\section{Respirable Materials}

SRMs $1878 \mathrm{~b}$ and $1879 \mathrm{~b}$ are crystalline silica materials with particle size in the respirable range. They are intended for use in determining, by $\mathrm{x}$-ray diffraction, the levels of respirable silica in an industrial atmosphere according to National Institute for Occupational Safety and Health (NIOSH) Analytical Method 7500 or equivalent methods.

\begin{tabular}{|l|l|c|}
\hline SRM & Description & $\begin{array}{c}\text { Unit of } \\
\text { Issue }\end{array}$ \\
\hline $\mathbf{1 6 4 8 a}$ & Urban Particulate Matter & $2 \mathrm{~g}$ \\
\hline $\mathbf{1 6 4 9 b}$ & Urban Dust & $2 \mathrm{~g}$ \\
\hline $\mathbf{1 6 5 0 b}$ & Diesel Particulate Matter & $200 \mathrm{mg}$ \\
\hline $\mathbf{1 8 7 7}$ & Beryllium Oxide Powder & $20 \mathrm{~g}$ \\
\hline $\mathbf{1 8 7 8 b}$ & $\begin{array}{l}\text { Respirable Alpha Quartz (Quantitative } \\
\text { X-Ray Powder Diffraction Standard) }\end{array}$ & $5 \mathrm{~g}$ \\
\hline $\mathbf{1 8 7 9 b}$ & $\begin{array}{l}\text { Respirable Cristobalite (Quantitative } \\
\text { X-Ray Powder Diffraction Standard) }\end{array}$ & $5 \mathrm{~g}$ \\
\hline $\mathbf{1 9 7 5}$ & Diesel Particulate Extract & $4 \mathrm{x} 1.2 \mathrm{~mL}$ \\
\hline $\mathbf{2 5 8 3}$ & $\begin{array}{l}\text { Trace Elements in Indoor Dust (Nominal } \\
\text { Mass Fraction of 90 mg/kg Lead) }\end{array}$ & $8 \mathrm{~g}$ \\
\hline $\mathbf{2 5 8 4}$ & $\begin{array}{l}\text { Trace Elements in Indoor Dust (Nominal } \\
\text { Mass Fraction of } 1 \% \text { Lead) }\end{array}$ & $8 \mathrm{~g}$ \\
\hline $\mathbf{2 5 8 5}$ & Organic Contaminants in House Dust & $10 \mathrm{~g}$ \\
\hline $\mathbf{2 7 8 6}$ & $\begin{array}{l}\text { Fine Atmospheric Particulate Matter } \\
\text { (Mean Particle Diameter }<4 \mu \mathrm{m})\end{array}$ & $100 \mathrm{mg}$ \\
\hline $\mathbf{2 7 8 7}$ & $\begin{array}{l}\text { Fine Atmospheric Particulate Matter } \\
\text { (Mean Particle Diameter }<10 \mu \mathrm{m})\end{array}$ & $100 \mathrm{mg}$ \\
\hline $\mathbf{2 9 7 5}$ & $\begin{array}{l}\text { Diesel Particulate Matter (Industrial } \\
\text { Forklift) }\end{array}$ & $1 \mathrm{~g}$ \\
\hline
\end{tabular}

See Table 105.12 on the website for more information.

Fax: 301.948.3730 | Email: srminfo@nist.gov 


\section{DNA Profiling and Nucleic Acid Materials (solid forms)}

SRM 2374 is intended for use as a template for ribonucleic acid (RNA) control synthesis using in vitro transcription (IVT). These RNA controls are designed to be used as external, or "spikein", controls to support confidence in gene expression assays by providing quantitative assessment of the technical performance of a gene expression measurement. A unit of the SRM contains 96 different $0.5 \mathrm{~mL}$ polypropylene tubes, with approximately 10 $\mu \mathrm{g}$ of dehydrated plasmid deoxyribonucleic acid (DNA) in each tube. Depending on the strand transcribed, the controls will mimic either "sense" or "anti-sense" eukaryotic messenger RNA (mRNA).

SRM 2391c is intended for use in the standardization of forensic and paternity quality assurance procedures and instructional law enforcement or non-clinical research purposes. SRM 2391c includes short tandem repeat (STR) information for all genomic DNA samples in the SRM. The STR data includes the Federal Bureau of Investigation's (FBI's) CODIS (Combined DNA Index System) core STR loci and other loci that were commercially available at the time of certification. Certified values for a total of 54 STR loci plus Amelogenin, 29 of which are Y-STRs, Reference values for 26 STR loci, and Information values for 1 STR locus, $12 \mathrm{X}$-STR loci, and 30 Insertion/Deletions (Indels) are included in this issue. The new standard includes well-characterized DNA in two forms: genomic DNA and DNA to be extracted from cells spotted onto 903 and FTA filter papers. SRM 2391c consists of 6 components packaged in one box and stored at refrigeration temperatures (NOT frozen).

SRM 2392 is intended to provide quality control when performing the polymerase chain reaction (PCR) and sequencing of human mitochondrial DNA (mtDNA) for forensic identifications, medical diagnosis, or mutation detection. It may also be used as a control when amplifying (PCR) and sequencing any DNA. SRM 2392 Mitochondrial DNA Sequencing contains DNA extracted from two cell lines plus cloned DNA from a region that is difficult to sequence. The certificate accompanying the SRM details the base pair sequences of the DNA, and the sequences of 58 unique primer sets which permit the amplification and sequencing of any specific area or the entire human mitochondrial DNA (strand). SRM 2392 consists of three frozen components packaged in one box. For further information see: SP260-155

SRM 2392-I Mitochondrial DNA Sequencing compliments and adds another DNA template to SRM 2392 for the amplification and sequencing of human mtDNA. The selection of the HL-60 cell culture line for this additional DNA template was based on a suggestion from the Federal Bureau of Investigation (FBI) that this DNA would be particularly useful to the forensic community. For further information see: SP260-155
SRM 2394 Heteroplasmic Mitochondrial DNA Mutation Standard contains mixtures of a 285 base pair polymerase chain reaction (PCR) product from two different cell culture lines that differ by one base pair. These mixtures contain varying ratios of the minor/ major heteroplasmy including 1/99, 2.5/97.5, 5/95, 10/90, 20/80, $30 / 70,40 / 60$, and 50/50. This SRM is intended to provide quality control in determining the sensitivity of heteroplasmic lowfrequency single nucleotide mutation detection techniques.

RMs 8375, 8391, 8392, 8393, and 8398 are intended for assessing performance of human genome sequencing, including whole genome sequencing, whole exome sequencing, and more targeted sequencing such as gene panels. Specifically, the material can be used to obtain estimates of true positives, false positives, true negatives, and false negatives for variant calls.

\begin{tabular}{|c|c|c|}
\hline SRM & Description & $\begin{array}{l}\text { Unit of } \\
\text { Issue }\end{array}$ \\
\hline $2366 a$ & $\begin{array}{l}\text { Cytomegalovirus DNA (Towne } \Delta 147 \text { BAC) } \\
\text { for DNA Measurements }\end{array}$ & 1 vial \\
\hline 2372 & Human DNA Quantitation Standard & $\operatorname{set}(3)$ \\
\hline 2373 & $\begin{array}{l}\text { Genomic DNA Standards for } \\
\text { HER2 Measurements }\end{array}$ & 5 vials \\
\hline 2374 & $\begin{array}{l}\text { DNA Sequence Library for External } \\
\text { RNA Controls }\end{array}$ & 96 tubes \\
\hline 2391c & PCR-Based DNA Profiling Standard & 6 vials \\
\hline 2392 & Mitochondrial DNA Sequencing & set (3) \\
\hline 2392-I & Mitochondrial DNA Sequencing & 1 vial \\
\hline 2393 & $\begin{array}{l}\text { CAG Repeat Length Mutation } \\
\text { in Huntington's Disease }\end{array}$ & set (6) \\
\hline 2394 & $\begin{array}{l}\text { Heteroplasmic Mitochondrial DNA } \\
\text { Mutation Detection Standard }\end{array}$ & set $(10)$ \\
\hline 2396 & $\begin{array}{l}\text { Oxidative DNA Damage Mass } \\
\text { Spectrometry Standards }\end{array}$ & set (10) \\
\hline 8375 & $\begin{array}{l}\text { Microbial Genomic DNA Standards } \\
\text { for Sequencing Performance Assessment }\end{array}$ & 4 vials \\
\hline 8391 & $\begin{array}{l}\text { Human DNA for Whole-Genome } \\
\text { Variant Assessment (Son of Eastern } \\
\text { European Ashkenazim Jewish Ancestry) }\end{array}$ & 1 vial \\
\hline 8392 & $\begin{array}{l}\text { Human DNA for Whole-Genome } \\
\text { Variant Assessment (Trio of Eastern } \\
\text { European Ashkenazim Jewish Ancestry) }\end{array}$ & 3 vials \\
\hline 8393 & $\begin{array}{l}\text { Human DNA for Whole-Genome Variant } \\
\text { Assessment (Son of Chinese Ancestry) }\end{array}$ & 1 vial \\
\hline 8398 & $\begin{array}{l}\text { Human DNA for Whole-Genome Variant } \\
\text { Assessment (Daughter of Utah/European } \\
\text { Ancestry) }\end{array}$ & 1 vial \\
\hline
\end{tabular}

See Table 105.8 on the website for more information.

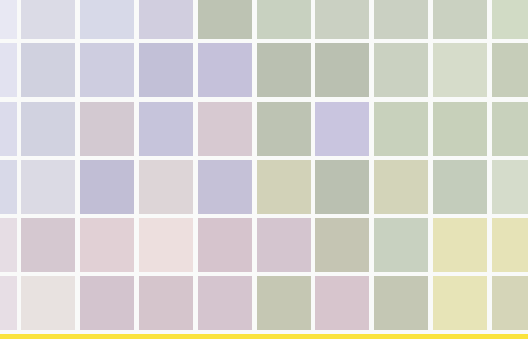




\section{Lead in Paint, Dust, and Soil (powder and sheet forms)}

These SRMs and RM have been developed in conjunction with the U.S. EPA to monitor paint, soil, and dust sources of lead. SRMs 2570 through 2576 consist of one MylarTM sheet per unit. Each sheet, $7.6 \mathrm{~cm} \times 10.2 \mathrm{~cm}$, is coated with a single uniform paint layer for use with portable X-ray fluorescence analyzers. SRMs 2580, 2581,2582 , and 2589 consist of paint that has been ground and homogenized into a powder, $99+\%$ of which passes a $100 \mathrm{~mm}$ sieve. SRM 2583 and SRM 2584 consist of dust, 99+\% of which passes a $100 \mathrm{~mm}$ sieve, that was collected in vacuum cleaner bags during cleaning of dwelling interiors. SRM 2583 and SRM 2584 are certified for arsenic, chromium, cadmium, lead, and mercury. [Also see Category 106.] SRMs 2584, 2586, and 2587 are dust or soil matrices containing lead from paint. RM 8680 consists of a $10.2 \mathrm{~cm}$ wide $\mathrm{x} 15.2 \mathrm{~cm}$ long $\mathrm{x} 1.3 \mathrm{~cm}$ thick section of painted fiberboard and is intended for use in the evaluation of destructive and nondestructive methods of measuring lead in paint on fiberboard.

\begin{tabular}{|l|l|c|}
\hline SRM & Description & $\begin{array}{c}\text { Unit of } \\
\text { Issue }\end{array}$ \\
\hline $\mathbf{1 6 4 8 a}$ & Urban Particulate Matter & $2 \mathrm{~g}$ \\
\hline $\mathbf{2 5 6 9}$ & Lead Paint Films for Children's Products & 8 sheets \\
\hline $\mathbf{2 5 7 0}$ & $\begin{array}{l}\text { Lead Paint Film for Portable X-Ray } \\
\text { Fluorescence Analyzers - Blank } \\
\text { (Color: White) }\end{array}$ & 1 film \\
\hline $\mathbf{2 5 7 1}$ & $\begin{array}{l}\text { Lead Paint Film for Building Surfaces } \\
\left.\text { (Nominal Pb } 3.5 \mathrm{mg} / \mathrm{cm}^{2}\right) \text { (Color: Yellow) }\end{array}$ & $1+$ blank \\
\hline $\mathbf{2 5 7 2}$ & $\begin{array}{l}\text { Lead Paint Film for Building Surfaces } \\
\left.\text { (Nominal Pb } 1.6 \mathrm{mg} / \mathrm{cm}^{2}\right) \text { (Color: Orange) }\end{array}$ & $1+$ blank \\
\hline $\mathbf{2 5 7 3}$ & $\begin{array}{l}\text { Lead Paint Film for Building Surfaces } \\
\left.\text { (Nominal Pb } 1.0 \mathrm{mg} / \mathrm{cm}^{2}\right) \text { (Color: Red) }\end{array}$ & $1+$ blank \\
\hline $\mathbf{2 5 7 4}$ & $\begin{array}{l}\text { Lead Paint Film for Building Surfaces } \\
\left.\text { (Nominal Pb } 0.7 \mathrm{mg} / \mathrm{cm}^{2}\right) \text { (Color: Gold) }\end{array}$ & $1+$ blank \\
\hline
\end{tabular}

\begin{tabular}{|c|c|c|}
\hline SRM & Description & $\begin{array}{l}\text { Unit of } \\
\text { Issue }\end{array}$ \\
\hline 2575 & $\begin{array}{l}\text { Lead Paint Film for Building Surfaces } \\
\left.\text { (Nominal } \mathrm{Pb} 0.3 \mathrm{mg} / \mathrm{cm}^{2}\right) \text { (Color: Green) }\end{array}$ & $1+$ blank \\
\hline 2576 & $\begin{array}{l}\text { Lead Paint Film for Building Surfaces } \\
\left.\text { (Nominal } \mathrm{Pb} 5.6 \mathrm{mg} / \mathrm{cm}^{2}\right) \text { (Color: Blue) }\end{array}$ & $1+$ blank \\
\hline $2579 a$ & $\begin{array}{l}\text { Lead Paint Films For Building Surfaces } \\
\text { (SRM } 2570 \text { through SRM 2575) }\end{array}$ & set (6) \\
\hline 2580 & $\begin{array}{l}\text { Powdered Paint (Nominal Mass } \\
\text { Fraction } 4 \% \text { Lead) }\end{array}$ & $30 \mathrm{~g}$ \\
\hline 2581 & $\begin{array}{l}\text { Powdered Paint (Nominal Mass } \\
\text { Fraction } 0.5 \% \text { Lead) }\end{array}$ & $35 \mathrm{~g}$ \\
\hline 2582 & $\begin{array}{l}\text { Powdered Paint (Nominal Mass } \\
\text { Fraction } 200 \mathrm{mg} / \mathrm{kg} \text { Lead) }\end{array}$ & $20 \mathrm{~g}$ \\
\hline 2583 & $\begin{array}{l}\text { Trace Elements in Indoor Dust (Nominal } \\
\text { Mass Fraction of } 90 \mathrm{mg} / \mathrm{kg} \text { Lead) }\end{array}$ & $8 \mathrm{~g}$ \\
\hline 2584 & $\begin{array}{l}\text { Trace Elements in Indoor Dust (Nominal } \\
\text { Mass Fraction of } 90 \mathrm{mg} / \mathrm{kg} \text { Lead) }\end{array}$ & $8 \mathrm{~g}$ \\
\hline 2586 & $\begin{array}{l}\text { Trace Elements in Soil Containing Lead } \\
\text { From Paint (Nominal Mass } \\
\text { Fraction } 500 \mathrm{mg} / \mathrm{kg} \text { Lead) }\end{array}$ & $55 \mathrm{~g}$ \\
\hline 2587 & $\begin{array}{l}\text { Trace Elements in Soil (Nominal Mass } \\
\text { Fraction of } 3000 \mathrm{mg} / \mathrm{kg} \text { Lead) }\end{array}$ & $55 \mathrm{~g}$ \\
\hline 2589 & $\begin{array}{l}\text { Powdered Paint (Nominal Mass } \\
\text { Fraction 10\% Lead) }\end{array}$ & $35 \mathrm{~g}$ \\
\hline 2783 & $\begin{array}{l}\text { Air Particulate on Filter Media } \\
\text { (47 mm dia) }\end{array}$ & $2+2$ Blank \\
\hline 8680 & $\begin{array}{l}\text { Paint on Fiberboard, } \\
\text { Nominal } 1 \text { to } 2 \mathrm{mg} / \mathrm{cm}^{2} \text { Lead }\end{array}$ & each \\
\hline
\end{tabular}

See Table 105.13 on the website for more information.

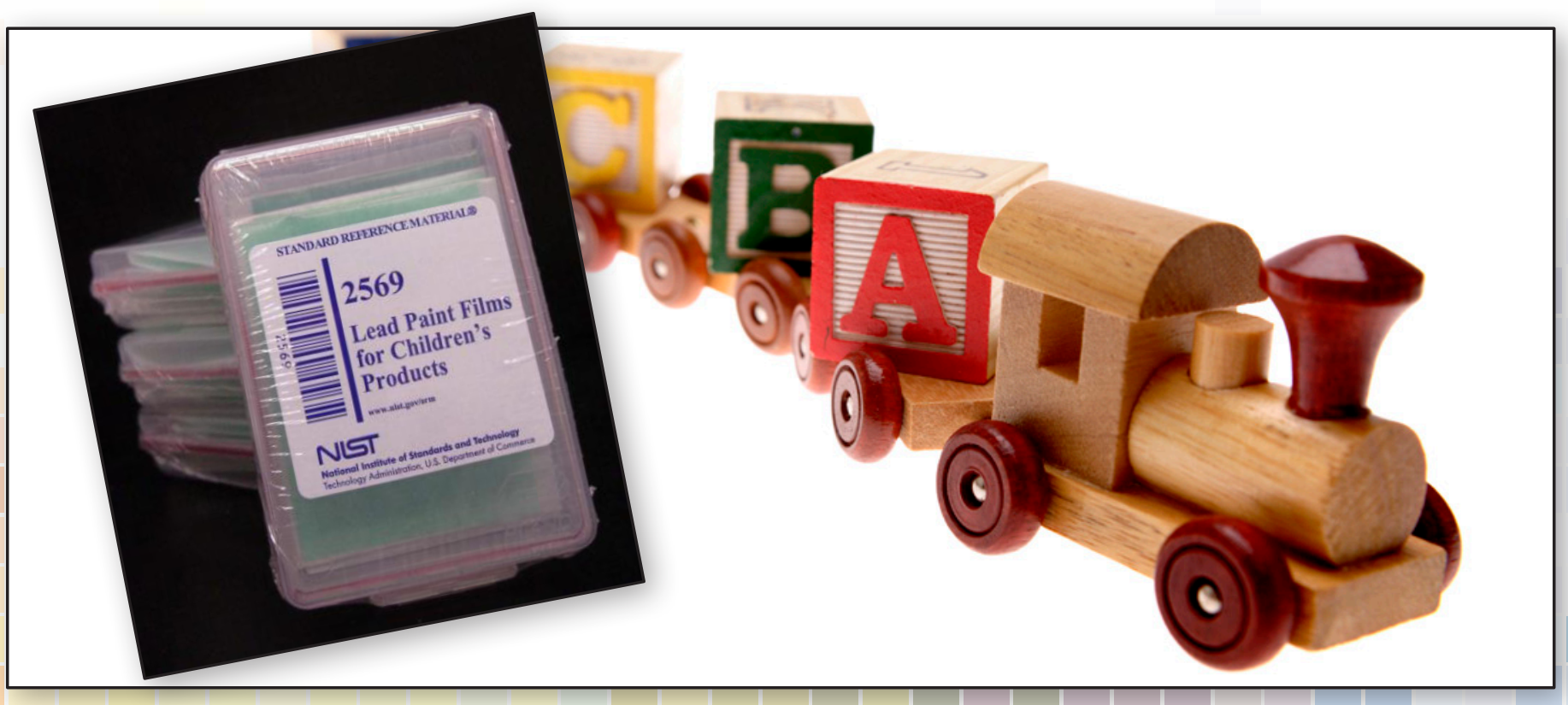




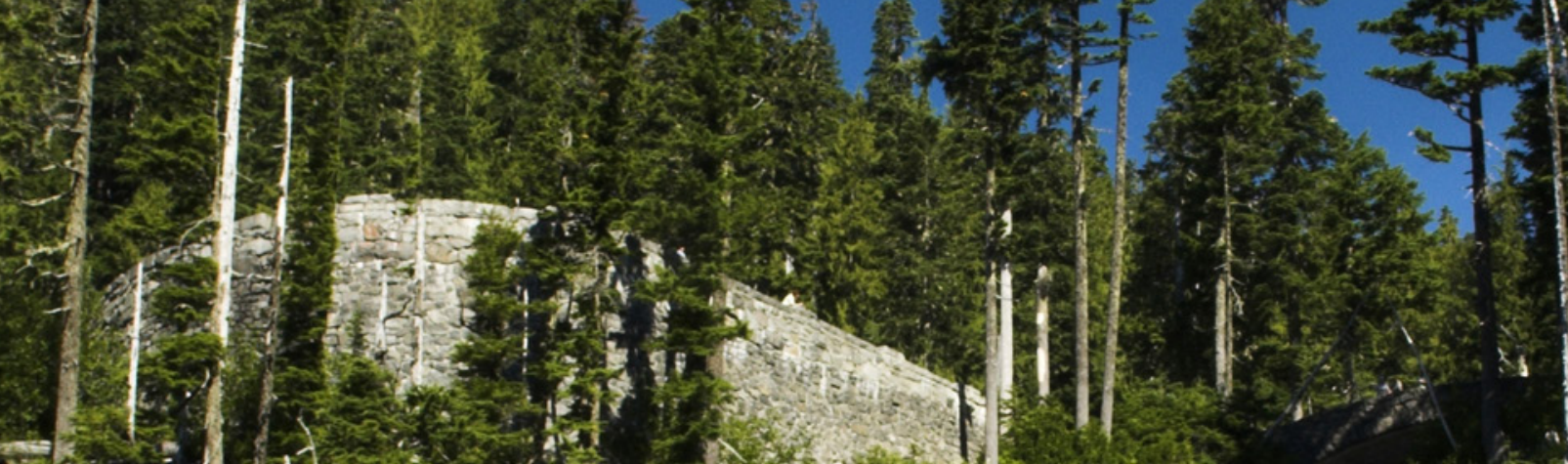




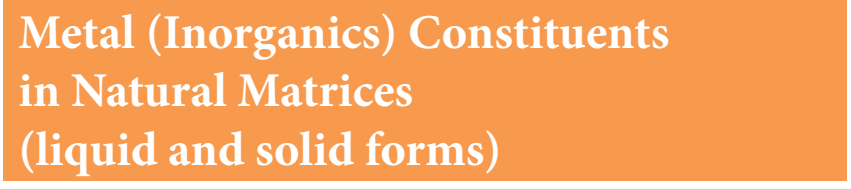

These SRMs and RM are for analysis of materials of health or environmental interest.

\begin{tabular}{|c|c|c|}
\hline SRM & Description & $\begin{array}{l}\text { Unit of } \\
\text { Issue }\end{array}$ \\
\hline $1640 \mathrm{a}$ & Trace Elements in Natural Water & $250 \mathrm{~mL}$ \\
\hline $1641 \mathrm{e}$ & Mercury in Water & $10 \times 10 \mathrm{~mL}$ \\
\hline $1643 f$ & Trace Elements in Water & $250 \mathrm{~mL}$ \\
\hline $1646 a$ & Estuarine Sediment & $70 \mathrm{~g}$ \\
\hline $1648 \mathrm{a}$ & Urban Particulate Matter & $2 \mathrm{~g}$ \\
\hline 1944 & New York/New Jersey Waterway Sediment & $50 \mathrm{~g}$ \\
\hline 1946 & Lake Superior Fish Tissue & $5 \times 7-9 g$ \\
\hline 1947 & Lake Michigan Fish Tissue & $5 \times 8 g$ \\
\hline 2385 & Slurried Spinach & $4 \times 70 \mathrm{~g}$ \\
\hline 2387 & Peanut Butter & $3 \times 170 \mathrm{~g}$ \\
\hline 2451 & $\begin{array}{l}\text { Fine Carbon (Activated) } \\
\text { From Cyanide Ore Leaching }\end{array}$ & $100 \mathrm{~g}$ \\
\hline 2583 & $\begin{array}{l}\text { Trace Elements in Indoor Dust (Nominal } \\
\text { Mass Fraction of } 90 \mathrm{mg} / \mathrm{kg} \text { Lead) }\end{array}$ & $8 \mathrm{~g}$ \\
\hline 2584 & $\begin{array}{l}\text { Trace Elements in Indoor Dust (Nominal } \\
\text { Mass Fraction of } 1 \% \text { Lead) }\end{array}$ & $8 \mathrm{~g}$ \\
\hline 2586 & $\begin{array}{l}\text { Trace Elements in Soil Containing Lead } \\
\text { From Paint (Nominal Mass } \\
\text { Fraction } 500 \mathrm{mg} / \mathrm{kg} \text { Lead) }\end{array}$ & $55 \mathrm{~g}$ \\
\hline 2587 & $\begin{array}{l}\text { Trace Elements in Soil (Nominal Mass } \\
\text { Fraction of } 3000 \mathrm{mg} / \mathrm{kg} \text { Lead) }\end{array}$ & $55 \mathrm{~g}$ \\
\hline 2700 & $\begin{array}{l}\text { Hexavalent Chromium in } \\
\text { Contaminated Soil (Low Level) }\end{array}$ & $75 \mathrm{~g}$ \\
\hline 2701 & $\begin{array}{l}\text { Hexavalent Chromium } \\
\text { in Contaminated Soil (High Level) }\end{array}$ & $75 \mathrm{~g}$ \\
\hline 2702 & Inorganics in Marine Sediment & $50 \mathrm{~g}$ \\
\hline 2703 & $\begin{array}{l}\text { Sediment for Solid Sampling } \\
\text { (Small Sample) Analytical Techniques }\end{array}$ & $5 \mathrm{~g}$ \\
\hline $2709 a$ & San Joaquin Soil & $50 \mathrm{~g}$ \\
\hline $2710 a$ & Montana I Soil & $50 \mathrm{~g}$ \\
\hline 2711a & Montana II Soil & $50 \mathrm{~g}$ \\
\hline $2780 a$ & Hard Rock Mine Waste & $50 \mathrm{~g}$ \\
\hline 2781 & Domestic Sludge & $40 \mathrm{~g}$ \\
\hline
\end{tabular}

\begin{tabular}{|l|l|c|}
\hline SRM & Description & $\begin{array}{c}\text { Unit of } \\
\text { Issue }\end{array}$ \\
\hline $\mathbf{2 7 8 2}$ & Industrial Sludge & $70 \mathrm{~g}$ \\
\hline $\mathbf{2 7 8 3}$ & $\begin{array}{l}\text { Air Particulate on Filter Media } \\
\text { (47 mm dia) }\end{array}$ & $2+2$ Blank \\
\hline $\mathbf{2 9 7 6}$ & $\begin{array}{l}\text { Mussel Tissue (Trace Elements \& } \\
\text { Methylmercury) Freeze-Dried }\end{array}$ & $25 \mathrm{~g}$ \\
\hline $\mathbf{8 7 0 4}$ & Buffalo River Sediment & $50 \mathrm{~g}$ \\
\hline $\mathbf{8 7 8 5}$ & Air Particulate Matter on Filter Media & 3 filters \\
\hline $\mathbf{8 7 8 6}$ & Filter Blank for RM 8785 & filter \\
\hline
\end{tabular}

See Table 106.1 on the website for more information.

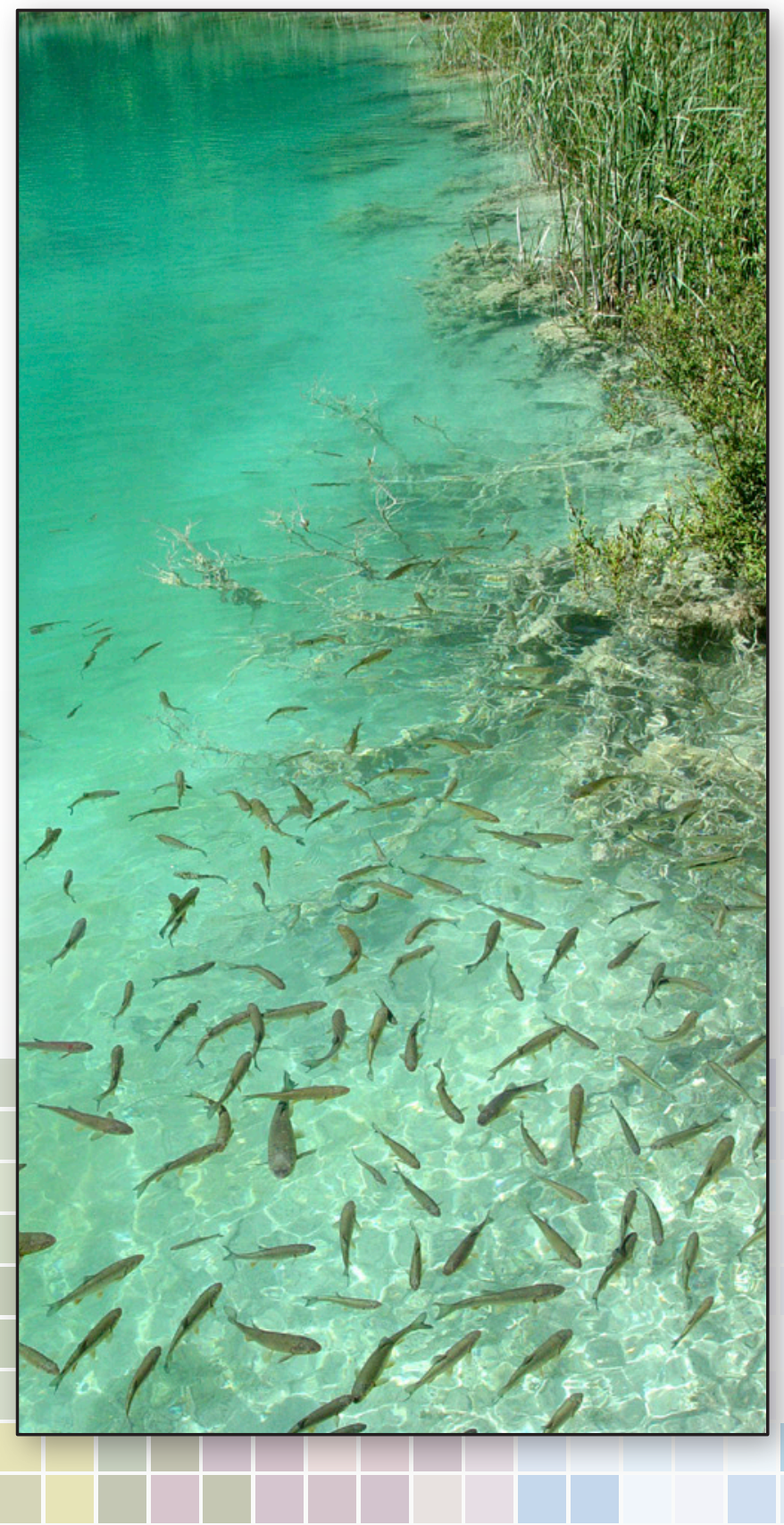




\section{Mercury in Activated Carbon}

These SRMs are intended for use in the evaluation of chemical methods of analysis for mercury.

\begin{tabular}{|l|l|c|}
\hline SRM & Description & $\begin{array}{c}\text { Unit of } \\
\text { Issue }\end{array}$ \\
\hline $\mathbf{2 4 4 5}$ & Mercury in Iodinated Activated Carbon & $25 \mathrm{~g}$ \\
\hline $\mathbf{2 4 4 8}$ & Mercury in Brominated Activated Carbon & $25 \mathrm{~g}$ \\
\hline $\mathbf{2 4 5 1}$ & $\begin{array}{l}\text { Fine Carbon (Activated) - From Cyanide } \\
\text { Ore Leaching }\end{array}$ & $100 \mathrm{~g}$ \\
\hline
\end{tabular}

See Table 106.3 on the website for more information.

\section{Environmental Matrices with Carbon Values}

These materials are intended for use in evaluating analytical methods used to measure carbon; SRM 1216 is intended for the calibration of instruments, used to measure total carbon.

\begin{tabular}{|l|l|c|}
\hline SRM & Description & $\begin{array}{c}\text { Unit of } \\
\text { Issue }\end{array}$ \\
\hline $\mathbf{1 2 1 6}$ & Carbon Modified Silica & $3 \times 1 \mathrm{~g}$ \\
\hline $\mathbf{1 6 3 2 d}$ & Trace Elements in Coal (Bituminous) & $50 \mathrm{~g}$ \\
\hline $\mathbf{1 9 4 4}$ & New York/New Jersey Waterway Sediment & $50 \mathrm{~g}$ \\
\hline $\mathbf{2 7 1 8 a}$ & Green Petroleum Coke & $50 \mathrm{~g}$ \\
\hline $\mathbf{2 7 1 9}$ & Calcined Petroleum Coke & $50 \mathrm{~g}$ \\
\hline $\mathbf{2 7 7 5}$ & Foundry Coke & $50 \mathrm{~g}$ \\
\hline $\mathbf{2 7 7 6}$ & Furnace Coke & $50 \mathrm{~g}$ \\
\hline $\mathbf{8 7 0 4}$ & Buffalo River Sediment & $50 \mathrm{~g}$ \\
\hline $\mathbf{8 7 8 5}$ & Air Particulate Matter on Filter Media & 3 filters \\
\hline $\mathbf{8 7 8 6}$ & Filter Blank for RM 8785 & filter \\
\hline
\end{tabular}

See Table 106.4 on the website for more information.

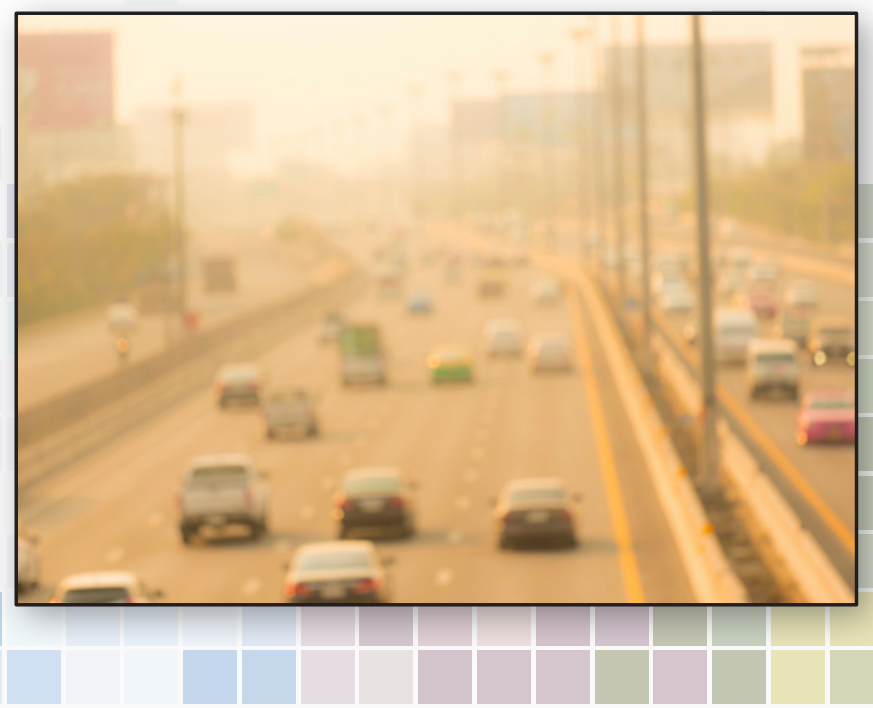

\section{Used Auto Catalysts (powder form)}

These SRMs are intended for use in the evaluation of methods for the analysis of the platinum group metals and lead in auto catalysts. They were produced in cooperation with the International Precious Metals Institute and are issued as fine (74 $\mu \mathrm{m}, 200$ mesh) powders.

\begin{tabular}{|l|l|c|}
\hline SRM & Description & $\begin{array}{c}\text { Unit of } \\
\text { Issue }\end{array}$ \\
\hline $\mathbf{2 5 5 6}$ & Used Auto Catalyst (Pellets) & $70 \mathrm{~g}$ \\
\hline $\mathbf{2 5 5 7}$ & Used Auto Catalyst (Monolith) & $70 \mathrm{~g}$ \\
\hline
\end{tabular}

See Table 106.6 on the website for more information.

\section{Zeolites (powder form)}

These RMs are intended to provide a common source of zeolite materials for measurement comparisons. Additional reference and information values are provided for atomic ratios of $\mathrm{Si}$ to $\mathrm{Al}$ and $\mathrm{Na}$ to $\mathrm{Al}$, trace element content, enthalpy of formation, unit cell parameters and particle size distributions. Figures are provided showing spectra for NMR analyses, plots of particle size distribution, electron microscope images of particles and plots of variation in sample mass with change in ambient humidity.

\begin{tabular}{|l|l|c|}
\hline SRM & Description & $\begin{array}{c}\text { Unit of } \\
\text { Issue }\end{array}$ \\
\hline $\mathbf{8 8 5 0}$ & Zeolite Y & $35-40 \mathrm{~g}$ \\
\hline $\mathbf{8 8 5 1}$ & Zeolite A & $35-40 \mathrm{~g}$ \\
\hline $\mathbf{8 8 5 2}$ & Ammonium ZSM-5 Zeolite & $35-40 \mathrm{~g}$ \\
\hline
\end{tabular}

See Table 106.7 on the website for more information.

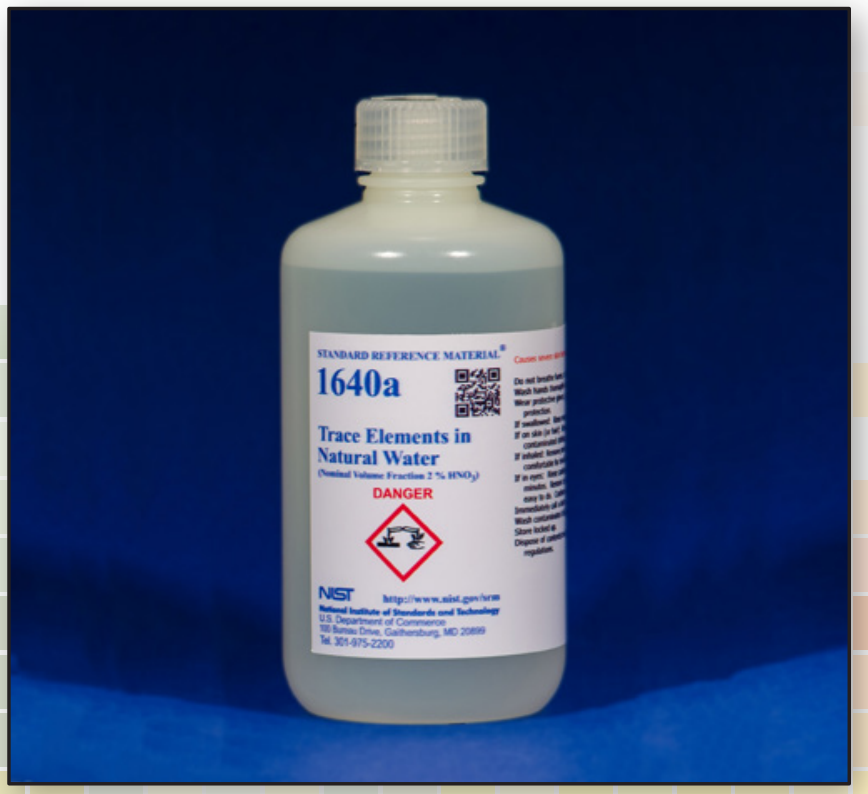


This page was intentionally left blank.

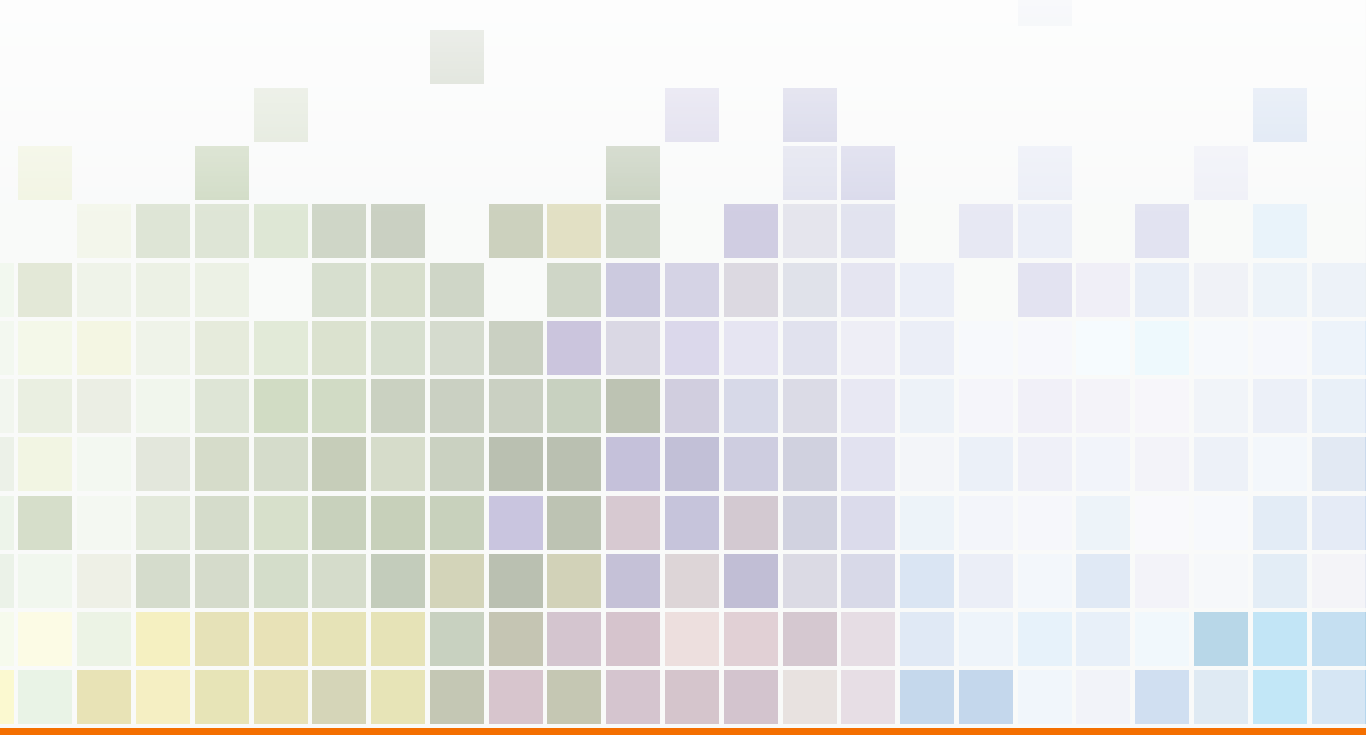



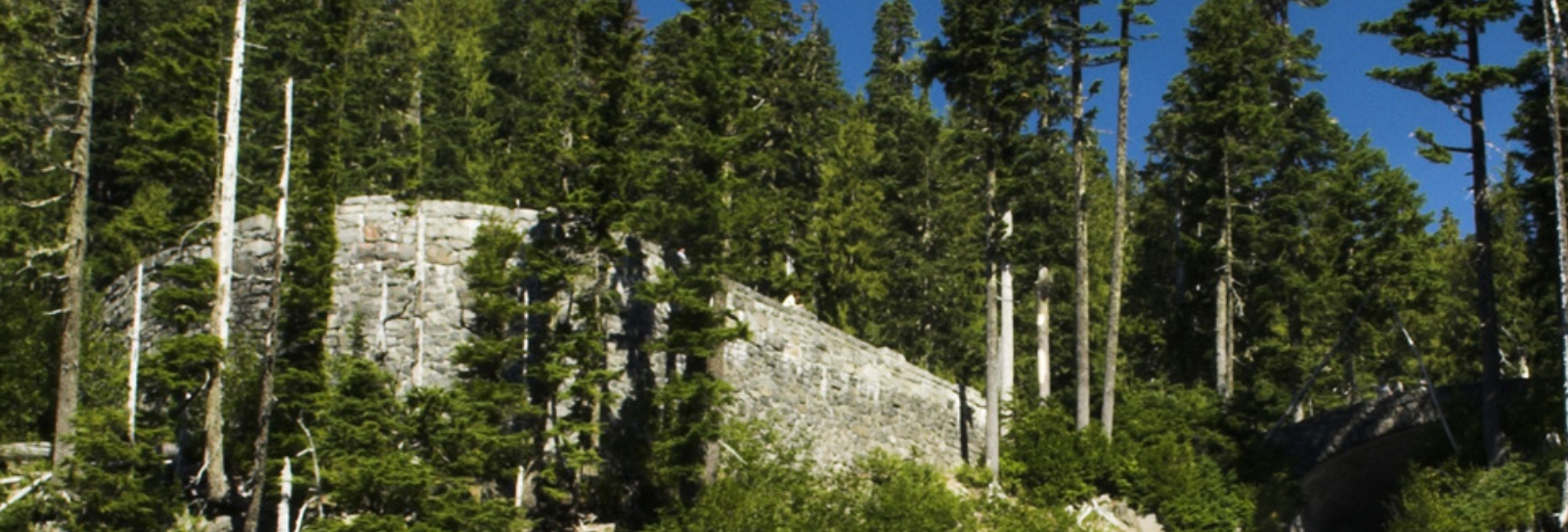

rimatin

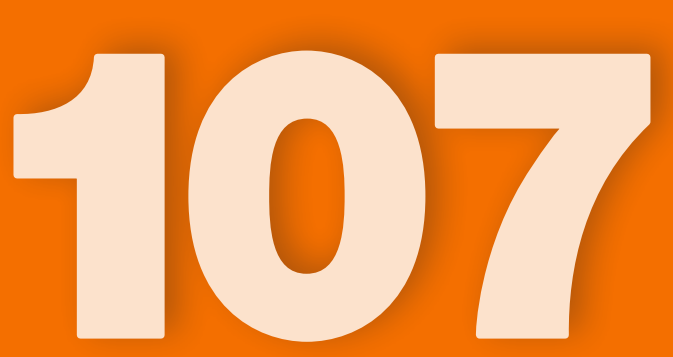

Standard Reference Materials far Chemical Campasitian

Primary Gas Mixtures

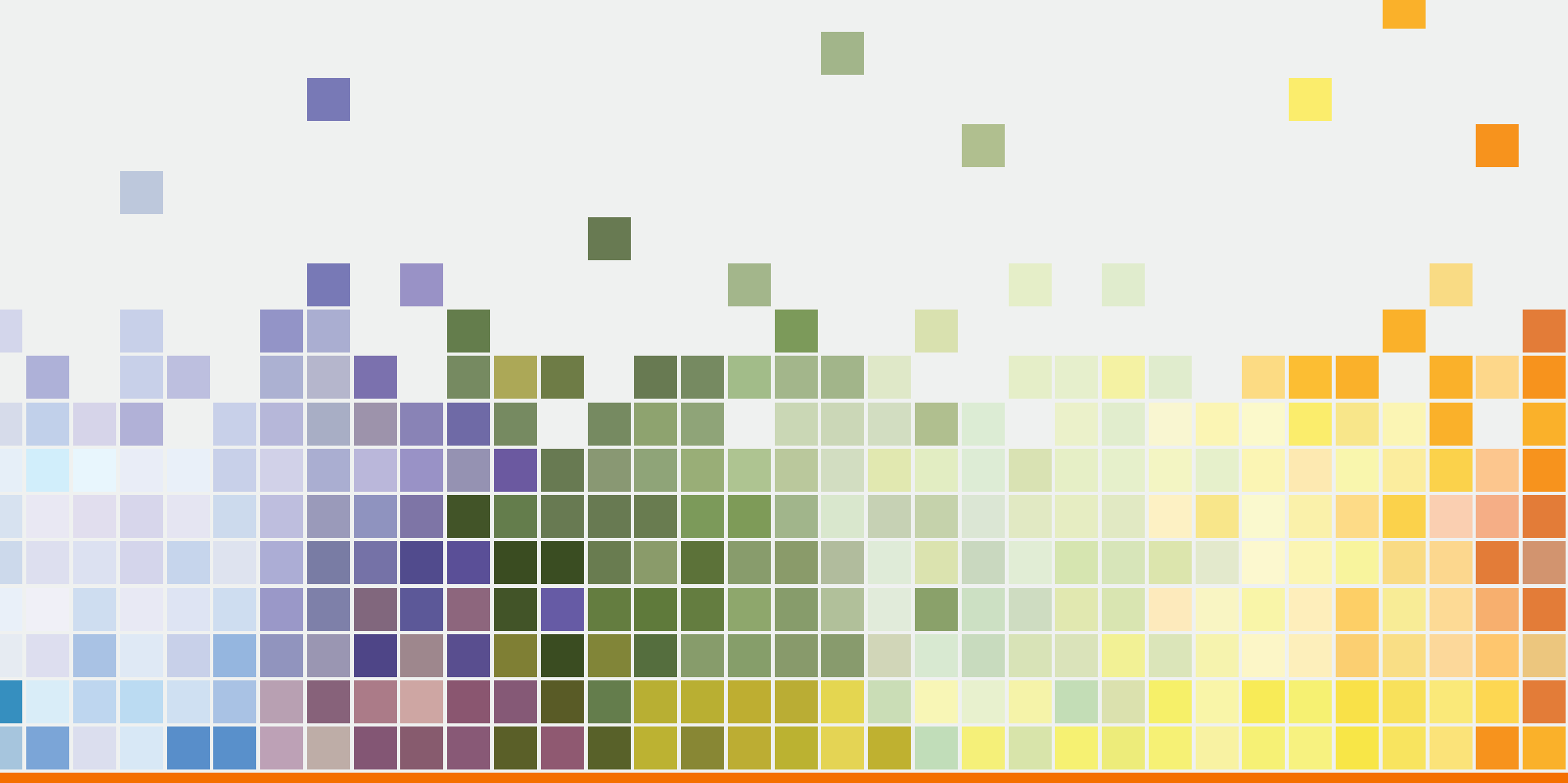

www.nist.gov/srm | Phone: 301.975.2200 | Fax: 301.948.3730 | Email: srminfo@nist.gov 


\section{Primary Gas Mixtures}

These SRMs are for calibrating equipment and apparatus used to measure various components of gas mixtures and atmospheric pollutants. The typical gas mixture is supplied in a DOT 3AL specification aluminum (6061 alloy) cylinder with a nominal pressure exceeding $12.4 \mathrm{mPa}$ that provides the user with approximately $0.73 \mathrm{~m}^{3}$ of usable mixture. Due to increasing customer demand, these primary gas mixtures are in short supply and may not be readily available for sale. In such cases, a NIST traceable reference gas described below may be substituted.

A NIST Traceable Reference Material (NTRM) is a reference material produced by a commercial supplier with a well-defined traceability to NIST. This traceability is established via criteria and protocols defined by NIST that are tailored to meet the needs of the metrological community to be served. The NTRM concept was established to allow NIST to respond to the increasing needs for high quality reference materials by leveraging its relatively fixed human and financial resources with secondary reference material producers. Reference material producers adhering to NIST defined protocol requirements are allowed to use the NTRM trademark to identify their product.

The gas NTRM program was established in 1992 in partnership with the U.S. EPA and specialty gas companies as a means for providing end-users with the wide variety of certified gas standards needed to implement the Emissions Trading provision of the 1990 Clean Air Act. Gas NTRMs are produced and distributed by specialty gas companies with NIST oversight of the production and maintenance, and direct involvement in the analysis. NTRMs can be developed for any pollutant, concentration, and balance gas combination for which a NIST primary standard or SRM exists. The gas standards prepared according to this program are related, within known limits of uncertainty, to specific gaseous primary standards maintained by NIST.

\section{SRM Description}

\section{Unit of Issue}

\begin{tabular}{|c|c|c|}
\hline & Carbon Dioxide & \\
\hline $2745^{*}$ & Carbon Dioxide in Nitrogen (Nominal Amount-of-Substance Fraction 16 \% mol/mol) & 6 L Cylinder \\
\hline $1674 b^{\star}$ & Carbon Dioxide in Nitrogen (Nominal Amount-of-Substance Fraction 7 \% mol/mol) & 6 L Cylinder \\
\hline $2624 a$ & Carbon Dioxide in Nitrogen (Nominal Amount-of-Substance Fraction 3 \% mol/mol) & 6 L Cylinder \\
\hline 2623a & Carbon Dioxide in Nitrogen (Nominal Amount-of-Substance Fraction $2.5 \% \mathrm{~mol} / \mathrm{mol}$ ) & 6 L Cylinder \\
\hline 2621a & Carbon Dioxide in Nitrogen (Nominal Amount-of-Substance Fraction $1.5 \%$ mol/mol) & 6 L Cylinder \\
\hline $2620 \mathrm{a}$ & Carbon Dioxide in Nitrogen (Nominal Amount-of-Substance Fraction 1 \% mol/mol) & 6 L Cylinder \\
\hline 2619a & Carbon Dioxide in Nitrogen (Nominal Amount-of-Substance Fraction $0.5 \%$ mol/mol) & 6 L Cylinder \\
\hline 2617 & Carbon Dioxide in Nitrogen (Nominal Amount-of-Substance Fraction 500 mol/mol) & 6 L Cylinder \\
\hline
\end{tabular}

\begin{tabular}{|l|l|c|}
\hline & Carbon Monoxide & \\
\hline 2614a & Carbon Monoxide in Air (Nominal Amount-of-Substance Fraction $45 \mu \mathrm{mol} / \mathrm{mol}$ ) & $6 \mathrm{~L}$ Cylinder \\
\hline 2613a & Carbon Monoxide in Air (Nominal Amount-of-Substance Fraction $20 \mu \mathrm{mol} / \mathrm{mol}$ ) & $6 \mathrm{~L}$ Cylinder \\
\hline 2741a & Carbon Monoxide in Nitrogen (Nominal Amount-of-Substance Fraction $13 \% \mathrm{~mol} / \mathrm{mol}$ ) & $6 \mathrm{~L}$ Cylinder \\
\hline 2740a & Carbon Monoxide in Nitrogen (Nominal Amount-of-Substance Fraction $10 \% \mathrm{~mol} / \mathrm{mol}$ ) & $6 \mathrm{~L}$ Cylinder \\
\hline 2642a* & Carbon Monoxide in Nitrogen (Nominal Amount-of-Substance Fraction $8 \% \mathrm{~mol} / \mathrm{mol}$ ) & $6 \mathrm{~L}$ Cylinder \\
\hline 2641a & Carbon Monoxide in Nitrogen (Nominal Amount-of-Substance Fraction $4 \% \mathrm{~mol} / \mathrm{mol})$ & $6 \mathrm{~L}$ Cylinder \\
\hline 2640a & Carbon Monoxide in Nitrogen (Nominal Amount-of-Substance Fraction $2 \% \mathrm{~mol} / \mathrm{mol}$ ) & $6 \mathrm{~L}$ Cylinder \\
\hline 2639a & Carbon Monoxide in Nitrogen (Nominal Amount-of-Substance Fraction $1 \% \mathrm{~mol} / \mathrm{mol}$ ) & $6 \mathrm{~L}$ Cylinder \\
\hline 2638a* & Carbon Monoxide in Nitrogen (Nominal Amount-of-Substance Fraction $5000 \mu \mathrm{mol} / \mathrm{mol}$ ) & $6 \mathrm{~L}$ Cylinder \\
\hline 2637a & Carbon Monoxide in Nitrogen (Nominal Amount-of-Substance Fraction $2500 \mu \mathrm{mol} / \mathrm{mol}$ ) & $6 \mathrm{~L}$ Cylinder \\
\hline 1681b* & Carbon Monoxide in Nitrogen (Nominal Amount-of-Substance Fraction $1000 \mu \mathrm{mol} / \mathrm{mol}$ ) & $6 \mathrm{~L}$ Cylinder \\
\hline
\end{tabular}




\section{Carbon Monoxide}

1680b $^{*}$ Carbon Monoxide in Nitrogen (Nominal Amount-of-Substance Fraction $500 \mu \mathrm{mol} / \mathrm{mol}$ )

2636a ${ }^{*}$ Carbon Monoxide in Nitrogen (Nominal Amount-of-Substance Fraction $250 \mu \mathrm{mol} / \mathrm{mol}$ )

1679 $c^{*}$ Carbon Monoxide in Nitrogen (Nominal Amount-of-Substance Fraction $100 \mu \mathrm{mol} / \mathrm{mol}$ )

L Cylinder

1678 $\mathbf{c}^{\star}$ Carbon Monoxide in Nitrogen (Nominal Amount-of-Substance Fraction $50 \mu \mathrm{mol} / \mathrm{mol}$ )

2635a ${ }^{\star}$ Carbon Monoxide in Nitrogen (Nominal Amount-of-Substance Fraction $25 \mu \mathrm{mol} / \mathrm{mol}$ )

$1677 \mathrm{c}^{\star}$ Carbon Monoxide in Nitrogen (Nominal Amount-of-Substance Fraction $10 \mu \mathrm{mol} / \mathrm{mol}$ )

6 L Cylinder
6 L Cylinder
6 L Cylinder
6 L Cylinder
6 L Cylinder
6 L Cylinder

\section{Nitric Oxide, Nitrous Oxide and Total Oxides of Nitrogen}

2631a* Nitric Oxide in Nitrogen (Nominal Amount-of-Substance Fraction $3000 \mu \mathrm{mol} / \mathrm{mol}$ )

2630* Nitric Oxide in Nitrogen (Nominal Amount-of-Substance Fraction $1500 \mu \mathrm{mol} / \mathrm{mol}$ )

6 L Cylinder

Nitric Oxide in Nitrogen (Nominal Amount-of-Substance Fraction $800 \mu \mathrm{mol} / \mathrm{mol}$ )

$6 \mathrm{~L}$ Cylinder

$1687 b^{*}$

Nitric Oxide in Nitrogen (Nominal Amount-of-Substance Fraction $1000 \mu \mathrm{mol} / \mathrm{mol}$ )

$1686 b^{*}$

Nitric Oxide in Nitrogen (Nominal Amount-of-Substance Fraction $500 \mu \mathrm{mol} / \mathrm{mol}$ )

6 L Cylinder

$1685 b^{*}$

Nitric Oxide in Nitrogen (Nominal Amount-of-Substance Fraction $250 \mu \mathrm{mol} / \mathrm{mol}$ )

6 L Cylinder

$1684 b^{*}$

Nitric Oxide in Nitrogen (Nominal Amount-of-Substance Fraction $100 \mu \mathrm{mol} / \mathrm{mol}$ )

6 L Cylinder

$1683 b^{*}$

Nitric Oxide in Nitrogen (Nominal Amount-of-Substance Fraction $50 \mu \mathrm{mol} / \mathrm{mol}$ )

6 L Cylinder

$6 \mathrm{~L}$ Cylinder

6 L Cylinder

2629a* Nitric Oxide in Nitrogen (Nominal Amount-of-Substance Fraction $20 \mu \mathrm{mol} / \mathrm{mol}$ )

6 L Cylinder

2628a

Nitric Oxide in Nitrogen (Nominal Amount-of-Substance Fraction $10 \mu \mathrm{mol} / \mathrm{mol}$ )

$6 \mathrm{~L}$ Cylinder

$2627 a$

Nitric Oxide in Nitrogen (Nominal Amount-of-Substance Fraction $5 \mu \mathrm{mol} / \mathrm{mol}$ )

6 L Cylinder

2738 Nitric Oxide in Nitrogen (Nominal Amount-of-Substance Fraction $1000 \mathrm{nmol} / \mathrm{mol}$ )

30 L Cylinder

2737 Nitric Oxide in Nitrogen (Nominal Amount-of-Substance Fraction $500 \mathrm{nmol} / \mathrm{mol}$ )

30 L Cylinder

1718 Nitrous Oxide in Air (Nominal Amount-of-Substance Fraction $1 \mu \mathrm{mol} / \mathrm{mol}$ )

6 L Cylinder

$2660 a^{*}$

Total Oxides of Nitrogen (NOx) in Air (Nominal Amount-of-Substance Fraction $100 \mu \mathrm{mol} / \mathrm{mol}$ )

6 L Cylinder

\begin{tabular}{|l|l|}
\hline & Oxygen \\
\hline $\mathbf{2 6 5 9} \mathbf{a}^{*}$ & Oxygen in Nitrogen (Nominal Amount-of-Substance Fraction $21 \% \mathrm{~mol} / \mathrm{mol}$ ) \\
\hline $\mathbf{2 6 5 8} \mathbf{a}^{*}$ & Oxygen in Nitrogen (Nominal Amount-of-Substance Fraction $10 \% \mathrm{~mol} / \mathrm{mol}$ ) \\
\hline $\mathbf{2 6 5 7} \mathbf{a}^{*}$ & Oxygen in Nitrogen (Nominal Amount-of-Substance Fraction $2 \% \mathrm{~mol} / \mathrm{mol}$ ) \\
\hline
\end{tabular}

6 L Cylinder

6 L Cylinder

6 L Cylinder

\begin{tabular}{|c|c|c|}
\hline & Sulfur Dioxide & \\
\hline $1696 a^{*}$ & Sulfur Dioxide in Nitrogen (Nominal Amount-of-Substance Fraction $3500 \mu \mathrm{mol} / \mathrm{mol}$ ) & 6 L Cylinder \\
\hline $1664 a^{*}$ & Sulfur Dioxide in Nitrogen (Nominal Amount-of-Substance Fraction $2500 \mu \mathrm{mol} / \mathrm{mol}$ ) & 6 L Cylinder \\
\hline $1662 a^{*}$ & Sulfur Dioxide in Nitrogen (Nominal Amount-of-Substance Fraction $1000 \mu \mathrm{mol} / \mathrm{mol}$ ) & 6 L Cylinder \\
\hline $1661 a^{*}$ & Sulfur Dioxide in Nitrogen (Nominal Amount-of-Substance Fraction $500 \mu \mathrm{mol} / \mathrm{mol}$ ) & 6 L Cylinder \\
\hline $1693 \mathbf{a}^{*}$ & Sulfur Dioxide in Nitrogen (Nominal Amount-of-Substance Fraction $50 \mu \mathrm{mol} / \mathrm{mol}$ ) & 6 L Cylinder \\
\hline 1689 & Sulfur Dioxide in Nitrogen (Nominal Amount-of-Substance Fraction $5 \mu \mathrm{mol} / \mathrm{mol}$ ) & 6 L Cylinder \\
\hline
\end{tabular}

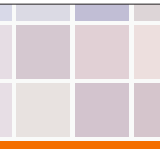




\section{SRM Description}

\begin{tabular}{|l|l|c|}
\hline & Hydrogen Sulfide & \\
\hline $\mathbf{2 7 3 1}$ & Hydrogen Sulfide in Nitrogen (Nominal Amount-of-Substance Fraction $20 \mu \mathrm{mol} / \mathrm{mol}$ ) & 6 L Cylinder \\
\hline $\mathbf{2 7 3 0}$ & Hydrogen Sulfide in Nitrogen (Nominal Amount-of-Substance Fraction $5 \mu \mathrm{mol} / \mathrm{mol}$ ) & 6 L Cylinder \\
\hline
\end{tabular}

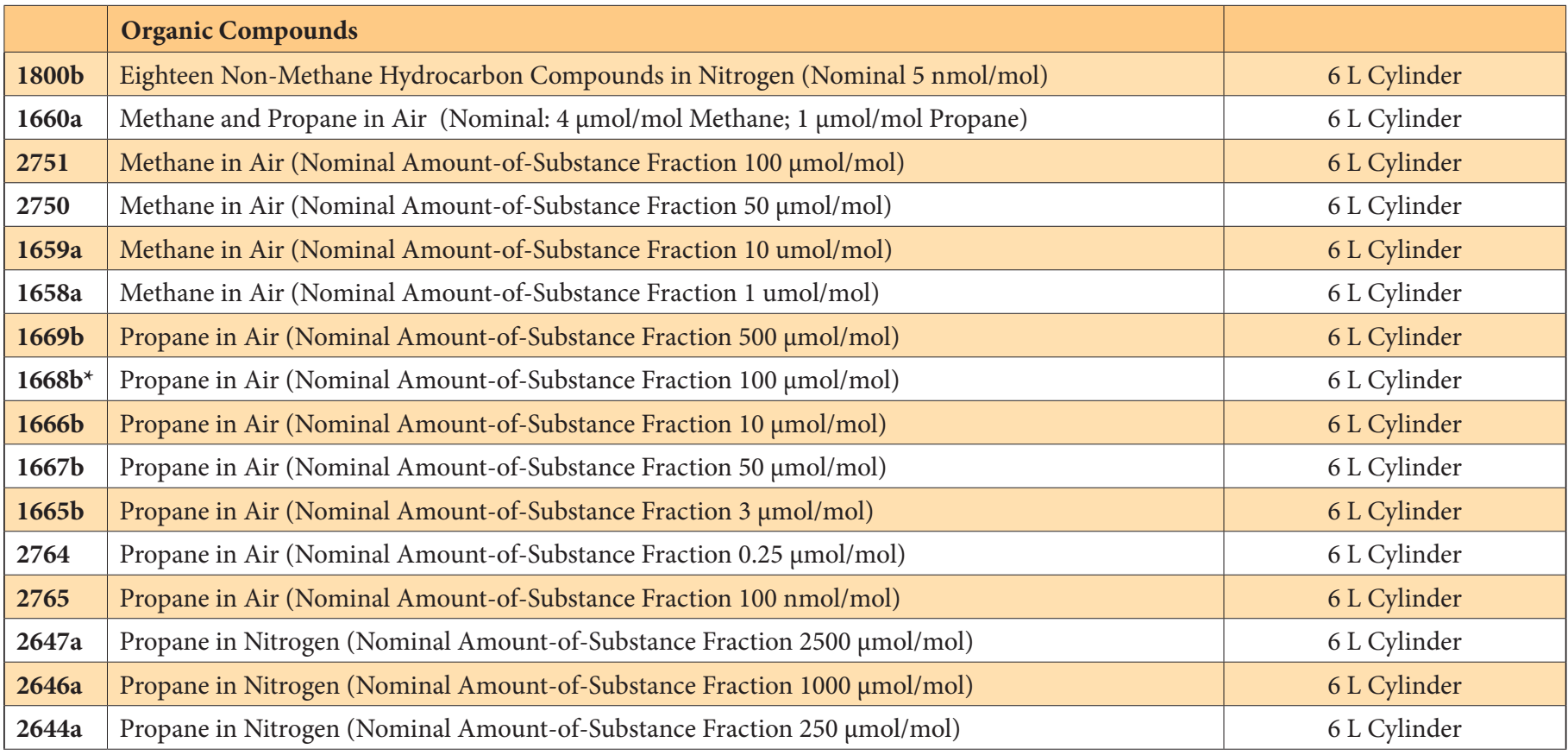

\begin{tabular}{|c|c|c|}
\hline & Ambient Air & \\
\hline 1720 & $\begin{array}{l}\text { Northern Continental Air (Ambient Nominal Amount-of-Substance Fraction: Carbon Dioxide, } \\
\text { Methane, Nitrous Oxide) }\end{array}$ & 30 L Cylinder \\
\hline
\end{tabular}

See Table 107.1 on the website for more information.

Those SRMs that are marked " " are available as NTRMs from commercial suppliers.

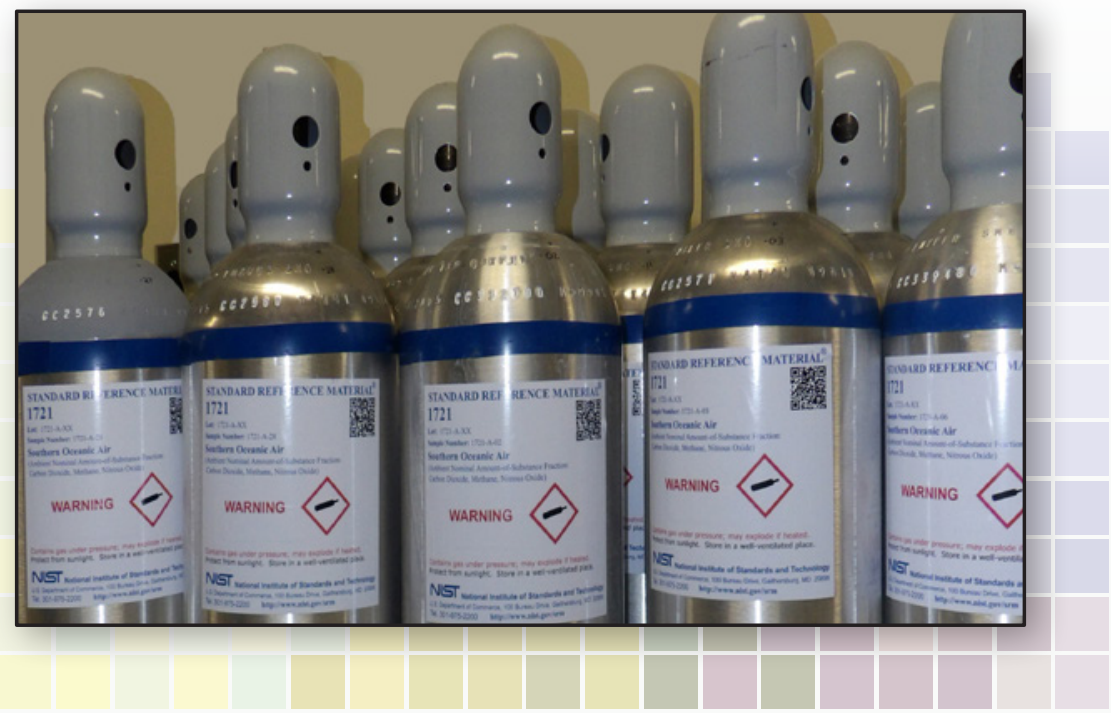



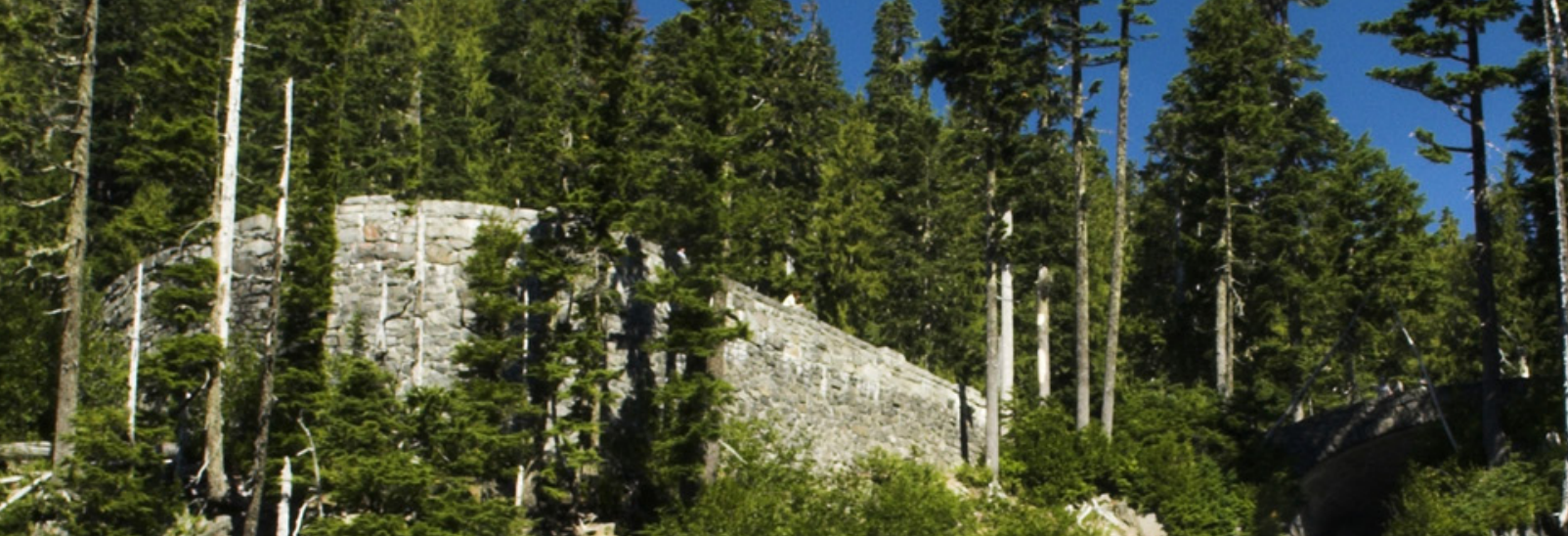

1.

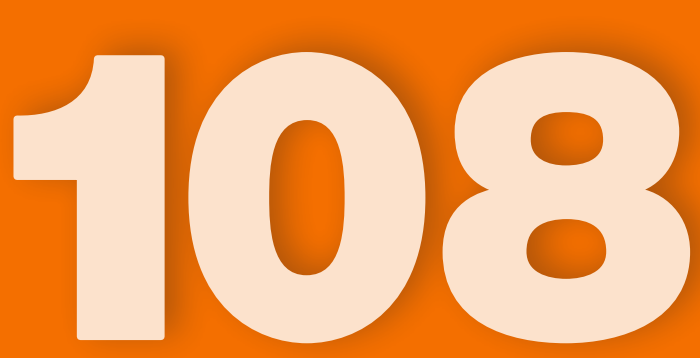

Standard Reference Materials far Chemical Campasitian

Fossil \& Alternative Fuels

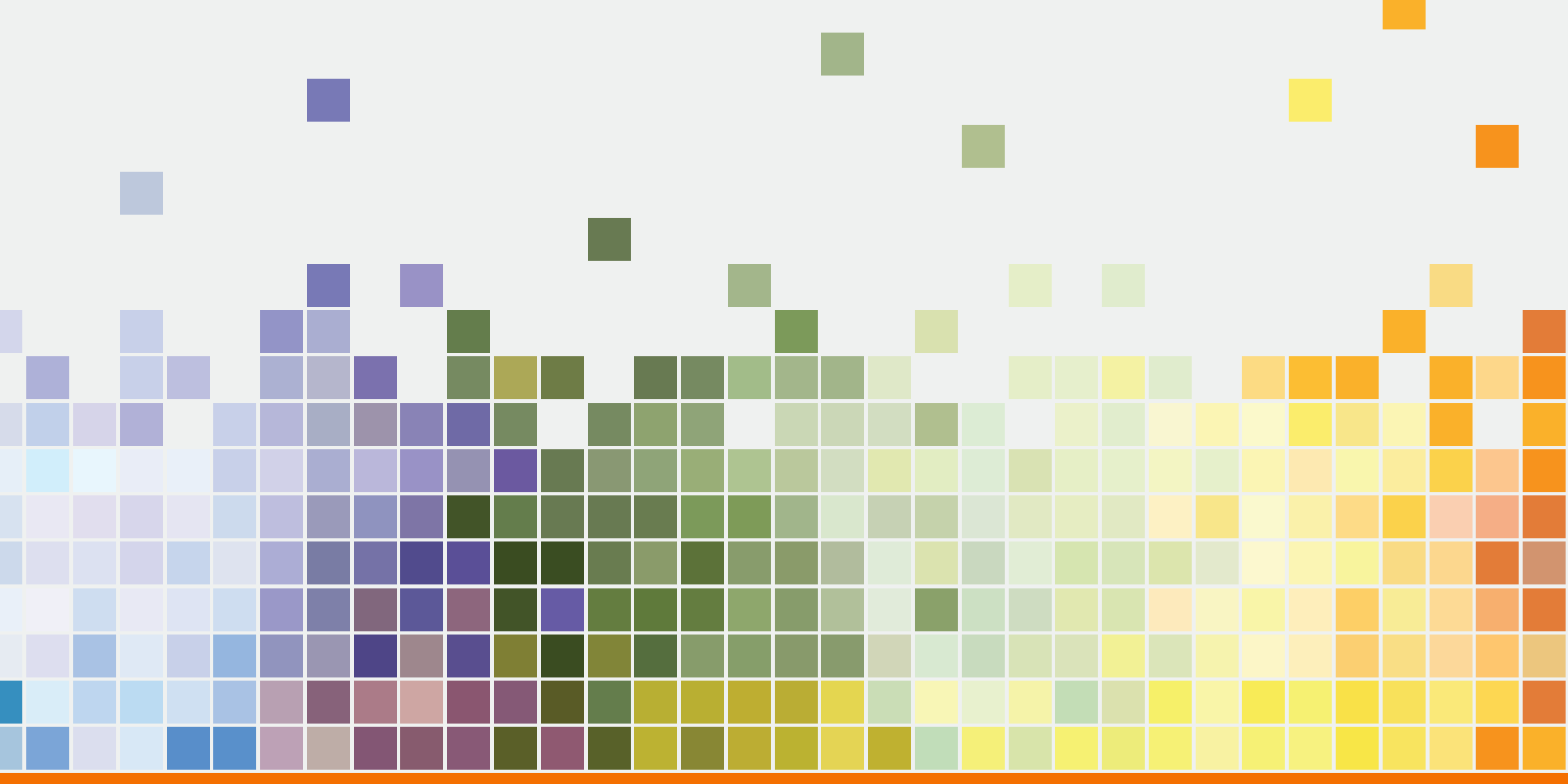

www.nist.gov/srm | Phone: 301.975.2200 | Fax: 301.948.3730 | Email: srminfo@nist.gov 


\section{Alcohols and Ethers [Oxygenates] in Gasoline}

SRMs 2294 through 2297 were produced in response to the U.S. EPA Final Rule on Reformulated Gas aimed at reducing the volatile organic compounds emitted from gasoline.

SRMs 2294 through 2297 are certified for oxygenate, sulfur, benzene, and toluene, with reference values for olefins and aromatics.

\begin{tabular}{|l|l|c|}
\hline SRM & Description & $\begin{array}{c}\text { Unit of } \\
\text { Issue }\end{array}$ \\
\hline 2294 & $\begin{array}{l}\text { Reformulated Gasoline } \\
\text { (Nominal Mass Fraction 11\% MTBE) }\end{array}$ & $2 \times 20 \mathrm{~mL}$ \\
\hline 2295 & $\begin{array}{l}\text { Reformulated Gasoline } \\
\text { (Nominal Mass Fraction 15\% MTBE) }\end{array}$ & $2 \times 20 \mathrm{~mL}$ \\
\hline 2296 & $\begin{array}{l}\text { Reformulated Gasoline } \\
\text { (Nominal Mass Fraction 13\% ETBE) }\end{array}$ & $2 \times 20 \mathrm{~mL}$ \\
\hline 2297 & $\begin{array}{l}\text { Reformulated Gasoline } \\
\text { (Nominal Mass Fraction 10\% Ethanol) }\end{array}$ & $2 \times 20 \mathrm{~mL}$ \\
\hline
\end{tabular}

See Table 108.1 on the website for more information.

\section{Metal Constituents in Fossil Fuels (liquid forms)}

This SRM and RM are for analysis of metal trace elements in fuel oil and reference fuel. SRM 1634c is a "No. 6" fuel oil in terms of viscosity but has a flash point of $43^{\circ} \mathrm{C}$.

\begin{tabular}{|l|l|c|}
\hline SRM & Description & $\begin{array}{c}\text { Unit of } \\
\text { Issue }\end{array}$ \\
\hline 1634c & Trace Elements in Fuel Oil & $100 \mathrm{~mL}$ \\
\hline $\mathbf{8 5 0 5}$ & Vanadium in Crude Oil & $250 \mathrm{~mL}$ \\
\hline
\end{tabular}

See Table 108.2 on the website for more information.

\section{Sulfur, Mercury, and Chlorine in Fuels (liquid and solid forms)}

These materials are for analysis of sulfur, mercury, and chlorine in fossil fuels.

\begin{tabular}{|l|l|c|}
\hline SRM & Description & $\begin{array}{c}\text { Unit of } \\
\text { Issue }\end{array}$ \\
\hline 1616b & Sulfur in Kerosene (Low Level) & $100 \mathrm{~mL}$ \\
\hline $\mathbf{1 6 1 7 b}$ & Sulfur in Kerosine (High Level) & $100 \mathrm{~mL}$ \\
\hline 1619b & Sulfur in Residual Fuel Oil (0.7 \%) & $100 \mathrm{~mL}$ \\
\hline 1620c & Sulfur in Residual Fuel Oil (4 \%) & $100 \mathrm{~mL}$ \\
\hline 1622e & $\begin{array}{l}\text { Sulfur in Residual Fuel Oil } \\
\text { (Nominal Mass Fraction 2\%) }\end{array}$ & $100 \mathrm{~mL}$ \\
\hline 1623c & Sulfur in Residual Fuel Oil 0.3\% & $100 \mathrm{~mL}$ \\
\hline 1624d & Sulfur in Diesel Fuel Oil, 0.4\% & $100 \mathrm{~mL}$ \\
\hline
\end{tabular}

\begin{tabular}{|c|c|c|}
\hline SRM & Description & $\begin{array}{l}\text { Unit of } \\
\text { Issue }\end{array}$ \\
\hline $1632 d$ & Trace Elements in Coal (Bituminous) & $50 \mathrm{~g}$ \\
\hline $1635 a$ & Trace Elements in Coal, (Subbitumimous) & $50 \mathrm{~g}$ \\
\hline 2294 & $\begin{array}{l}\text { Reformulated Gasoline } \\
\text { (Nominal Mass Fraction 11\% MTBE) }\end{array}$ & $2 \times 20 \mathrm{~mL}$ \\
\hline 2295 & $\begin{array}{l}\text { Reformulated Gasoline } \\
\text { (Nominal Mass Fraction } 15 \% \text { MTBE) }\end{array}$ & $2 \times 20 \mathrm{~mL}$ \\
\hline 2296 & $\begin{array}{l}\text { Reformulated Gasoline } \\
\text { (Nominal Mass Fraction } 13 \% \text { ETBE) }\end{array}$ & $2 \times 20 \mathrm{~mL}$ \\
\hline 2297 & $\begin{array}{l}\text { Reformulated Gasoline } \\
\text { (Nominal Mass Fraction } 10 \% \text { Ethanol) }\end{array}$ & $2 \times 20 \mathrm{~mL}$ \\
\hline 2298 & Sulfur in Gasoline (High-Octane) & $5 \times 20 \mathrm{~mL}$ \\
\hline 2299 & Sulfur in Gasoline (Reformulated) & $5 \times 20 \mathrm{~mL}$ \\
\hline $2682 c$ & $\begin{array}{l}\text { Subbituminous Coal } \\
\text { (Nominal Mass Fraction } 0.5 \% \text { Sulfur) }\end{array}$ & $1 \times 50 \mathrm{~g}$ \\
\hline $2683 c$ & $\begin{array}{l}\text { Bituminous Coal } \\
\text { (Nominal Mass Fraction } 2 \% \text { Sulfur) }\end{array}$ & $50 \mathrm{~g}$ \\
\hline $2684 c$ & $\begin{array}{l}\text { Bituminous Coal } \\
\text { (Nominal Mass Fraction } 3 \% \text { Sulfur) }\end{array}$ & $50 \mathrm{~g}$ \\
\hline $2685 c$ & $\begin{array}{l}\text { Bituminous Coal } \\
\text { (Nominal Mass Fraction } 5 \% \text { Sulfur) }\end{array}$ & $50 \mathrm{~g}$ \\
\hline 2693 & $\begin{array}{l}\text { Bituminous Coal } \\
\text { (Nominal Mass Fraction } 0.5 \% \text { Sulfur) }\end{array}$ & $50 \mathrm{~g}$ \\
\hline 2716 & Sulfur in Gasoline $(<1 \mathrm{mg} / \mathrm{kg})$ & $5 \times 20 \mathrm{~mL}$ \\
\hline $2717 a$ & $\begin{array}{l}\text { Sulfur in Residual Fuel Oil } \\
\text { (Nominal Mass Fraction } 3 \% \text { ) }\end{array}$ & $100 \mathrm{~mL}$ \\
\hline $2718 a$ & Green Petroleum Coke & $50 \mathrm{~g}$ \\
\hline 2719 & Calcined Petroleum Coke & $50 \mathrm{~g}$ \\
\hline 2720 & Sulfur in Di- $n$-Butyl Sulfide & $5 \times 4.5 \mathrm{~mL}$ \\
\hline 2721 & Crude Oil (Light-Sour) & $5 \times 10 \mathrm{~mL}$ \\
\hline 2722 & Crude Oil (Heavy Sweet) & $5 \times 10 \mathrm{~mL}$ \\
\hline $2723 b$ & $\begin{array}{l}\text { Sulfur in Diesel Fuel Oil } \\
\text { (Nominal Mass Fraction } 10 \text { mg/kg) }\end{array}$ & $100 \mathrm{~mL}$ \\
\hline 2770 & Sulfur in Diesel Fuel Oil (40 mg/kg) & $10 \times 10 \mathrm{~mL}$ \\
\hline 2771 & Sulfur in Diesel Fuel Blend Stock & $100 \mathrm{~mL}$ \\
\hline 2773 & B100 Biodiesel (Animal-Based) & $5 \times 10 \mathrm{~mL}$ \\
\hline 2775 & Foundry Coke & $50 \mathrm{~g}$ \\
\hline 2776 & Furnace Coke & $50 \mathrm{~g}$ \\
\hline
\end{tabular}

See Table 108.3 on the website for more infomration and additional resources. 


\section{Moisture in Oils and Alcohols (liquid form)}

SRM 2890, Water Saturated 1-Octanol, is certified for water content and is intended for use in calibrating instruments and validating the accuracy of analytical methods. Water concentration values, for RMs 8506a, 8509, and 8510 are not certified, but represent the "best estimate" of the moisture content determined by NIST, and are intended for use in developing and validating methods for the determination of moisture in oil and similar matrices.

\begin{tabular}{|l|l|c|}
\hline SRM & Description & $\begin{array}{c}\text { Unit of } \\
\text { Issue }\end{array}$ \\
\hline $\mathbf{2 7 2 1}$ & Crude Oil (Light -Sour) & $5 \times 10 \mathrm{~mL}$ \\
\hline $\mathbf{2 7 2 2}$ & Crude Oil (Heavy Sweet) & $5 \times 10 \mathrm{~mL}$ \\
\hline $\mathbf{2 8 9 0}$ & Water Saturated 1-Octanol & $5 \times 2 \mathrm{~mL}$ \\
\hline $\mathbf{8 5 0 6 a}$ & Moisture in Transformer Oil & $5 \times 9.5 \mathrm{~mL}$ \\
\hline $\mathbf{8 5 0 9}$ & Moisture in Methanol & $5 \times 5 \mathrm{~mL}$ \\
\hline $\mathbf{8 5 1 0}$ & Moisture in Methanol & $5 \times 5 \mathrm{~mL}$ \\
\hline
\end{tabular}

See Table 108.4 on the website for more information.

\section{Fossil Fuel: Trace Elements (solid forms)}

\begin{tabular}{|l|l|c|}
\hline SRM & Description & $\begin{array}{c}\text { Unit of } \\
\text { Issue }\end{array}$ \\
\hline $\mathbf{1 6 3 2 d}$ & Trace Elements in Coal (Bituminous) & $50 \mathrm{~g}$ \\
\hline $\mathbf{1 6 3 3 c}$ & Trace Elements in Coal Fly Ash & $75 \mathrm{~g}$ \\
\hline $\mathbf{1 6 3 5 a}$ & Trace Elements in Coal, (Subbitumimous) & $50 \mathrm{~g}$ \\
\hline $\mathbf{2 4 2 9}$ & Flue Gas Desulfurization Gypsum & $1 \times 200 \mathrm{~g}$ \\
\hline $\mathbf{2 6 8 9}$ & Coal Fly Ash & $3 \times 10 \mathrm{~g}$ \\
\hline $\mathbf{2 6 9 0}$ & Coal Fly Ash & $3 \times 10 \mathrm{~g}$ \\
\hline $\mathbf{2 6 9 1}$ & Coal Fly Ash & $3 \times 10 \mathrm{~g}$ \\
\hline $\mathbf{2 7 1 8 a}$ & Green Petroleum Coke & $50 \mathrm{~g}$ \\
\hline $\mathbf{2 7 1 9}$ & Calcined Petroleum Coke & $50 \mathrm{~g}$ \\
\hline
\end{tabular}

See Table 108.6 on the website for more information.

\section{Biofuels}

\begin{tabular}{|l|l|c|}
\hline SRM & Description & $\begin{array}{c}\text { Unit of } \\
\text { Issue }\end{array}$ \\
\hline $\mathbf{2 3 7 7}$ & $\begin{array}{l}\text { Fatty Acid Methyl Esters in } \\
2,2,4-\text { Trimethylpentane }\end{array}$ & $5 \times 1.2 \mathrm{~mL}$ \\
\hline $\mathbf{2 7 7 2}$ & B100 Biodiesel (Soy-Based) & $5 \times 10 \mathrm{~mL}$ \\
\hline $\mathbf{2 7 7 3}$ & B100 Biodiesel (Animal-Based) & $5 \times 10 \mathrm{~mL}$ \\
\hline
\end{tabular}

See Table 108.8 on the website for more information.

\section{Biomass Feedstock}

\begin{tabular}{|l|l|c|}
\hline SRM & Description & $\begin{array}{c}\text { Unit of } \\
\text { Issue }\end{array}$ \\
\hline $\mathbf{8 4 9 1}$ & $\begin{array}{l}\text { Sugarcane Bagasse Whole } \\
\text { Biomass Feedstock }\end{array}$ & $50 \mathrm{~g}$ \\
\hline $\mathbf{8 4 9 2}$ & $\begin{array}{l}\text { Eastern Cottonwood Whole } \\
\text { Biomass Feedstock }\end{array}$ & $50 \mathrm{~g}$ \\
\hline $\mathbf{8 4 9 3}$ & Monterey Pine Whole Biomass Feedstock & $50 \mathrm{~g}$ \\
\hline $\mathbf{8 4 9 4}$ & Wheat Straw Whole Biomass Feedstock & $50 \mathrm{~g}$ \\
\hline $\mathbf{8 4 9 5}$ & Northern Softwood & 10 sheets \\
\hline $\mathbf{8 4 9 6}$ & Eucalyptus Hardwood & 10 sheets \\
\hline
\end{tabular}

See Table 108.9 on the website for more information.

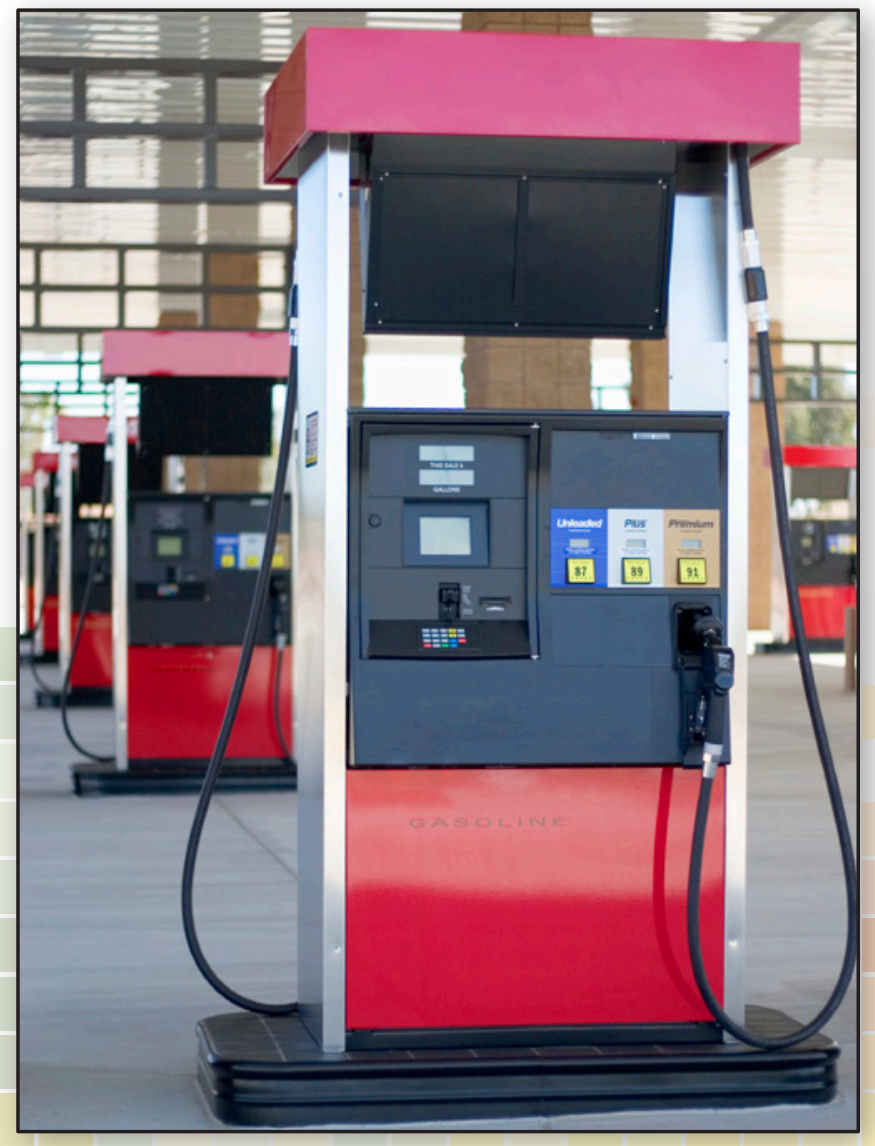




\section{Please visit the NIST Facebook page}

\section{https://www.facebook.com/usnistgov}

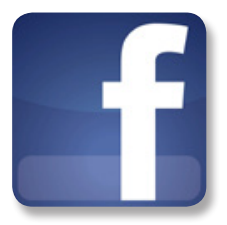

Follow NIST on Twitter

https://twitter.com/usnistgov

Follow @usnistgov

We appreciate your feedback! 


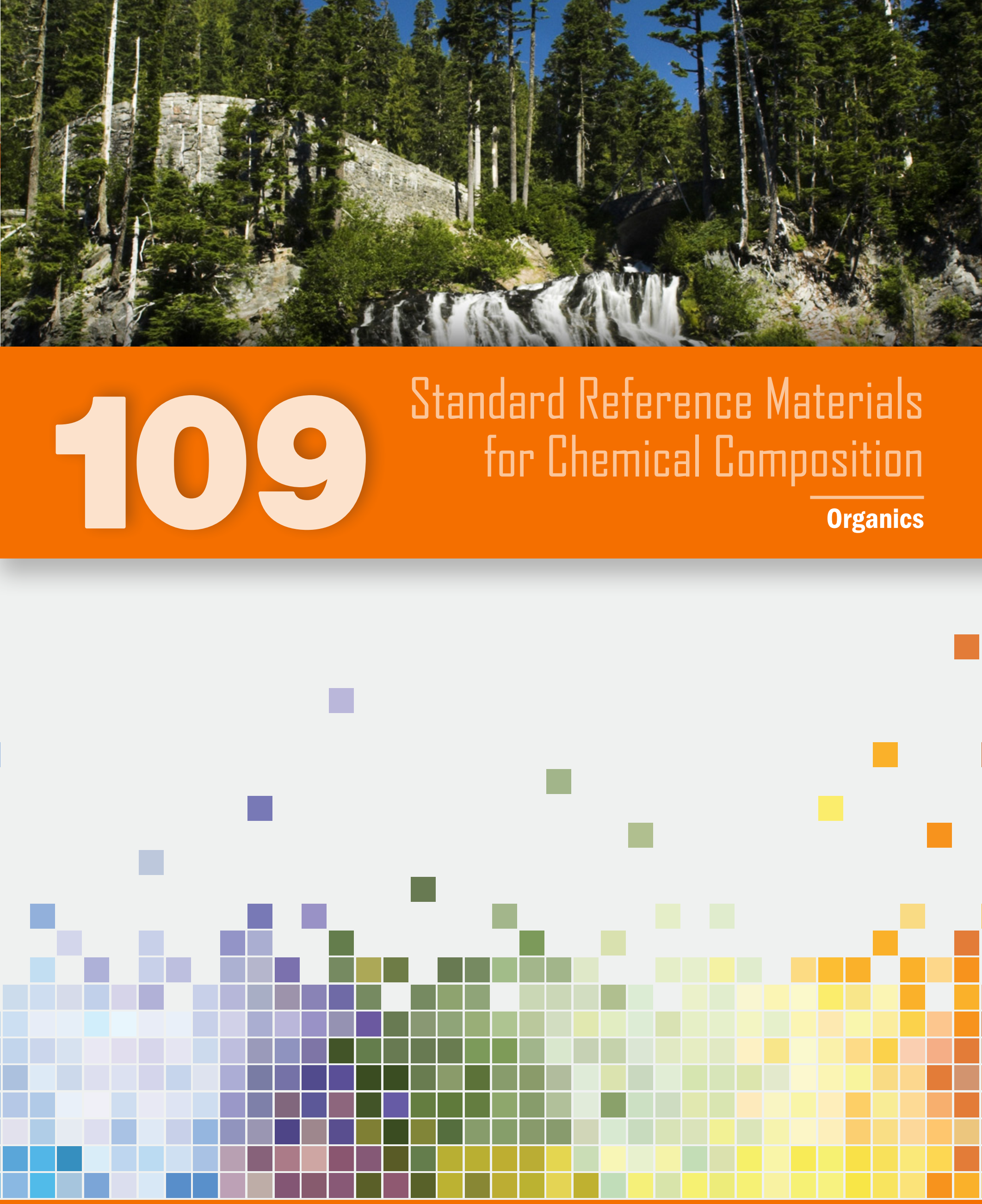

www.nist.gov/srm | Phone: 301.975.2200 | Fax: 301.948.3730 | Email: srminfo@nist.gov 
Organics

\begin{tabular}{|c|c|c|}
\hline SRM & Description & $\begin{array}{l}\text { Unit of } \\
\text { Issue }\end{array}$ \\
\hline $869 b$ & $\begin{array}{l}\text { Column Selectivity Test Mixture } \\
\text { for Liquid Chromatography }\end{array}$ & $5 \times 1.1 \mathrm{~mL}$ \\
\hline 870 & $\begin{array}{l}\text { Column Performance Test Mixture } \\
\text { for Liquid Chromatography }\end{array}$ & $5 \times 1.1 \mathrm{~mL}$ \\
\hline $1491 \mathrm{a}$ & $\begin{array}{l}\text { Methyl-Substituted Polycyclic Aromatic } \\
\text { Hydrocarbons in Toluene }\end{array}$ & $5 \times 1.2 \mathrm{~mL}$ \\
\hline 1492 & Chlorinated Pesticides in Hexane & $5 \times 1.2 \mathrm{~mL}$ \\
\hline 1493 & $\begin{array}{l}\text { Polychlorinated Biphenyl Congeners } \\
\text { in 2,2,4-Trimethylpentane }\end{array}$ & $5 \times 1.2 \mathrm{~mL}$ \\
\hline 1494 & $\begin{array}{l}\text { Aliphatic Hydrocarbons } \\
\text { in 2,2,4-Trimethylpentane }\end{array}$ & $5 \times 1.2 \mathrm{~mL}$ \\
\hline 1543 & GC/MS System Performance & $4 \times 1 \mathrm{~mL}$ \\
\hline 1584 & Priority Pollutant Phenols in Methanol & $5 \times 1.2 \mathrm{~mL}$ \\
\hline 1596 & $\begin{array}{l}\text { Dinitropyrene Isomers and } \\
\text { 1-Nitropyrene in Methylene Chloride }\end{array}$ & $5 \times 1.3 \mathrm{~mL}$ \\
\hline $1597 \mathbf{a}$ & $\begin{array}{l}\text { Complex Mixture of Polycyclic Aromatic } \\
\text { Hydrocarbons Coal Tar }\end{array}$ & $1 \times 1.3 \mathrm{~mL}$ \\
\hline 1614 & Dioxin $(2,3,7,8$-TCDD in Isooctane) & $6 \times 1.2 \mathrm{~mL}$ \\
\hline $1647 f$ & $\begin{array}{l}\text { Priority Pollutant Polycyclic Aromatic } \\
\text { Hydrocarbons in Acetonitrile }\end{array}$ & $5 \times 1.3 \mathrm{~mL}$ \\
\hline $1649 b$ & Urban Dust & $2 \mathrm{~g}$ \\
\hline $1650 \mathrm{~b}$ & Diesel Particulate Matter & $200 \mathrm{mg}$ \\
\hline 1941b & Organics in Marine Sediment & $50 \mathrm{~g}$ \\
\hline 1944 & New York/New Jersey Waterway Sediment & $50 \mathrm{~g}$ \\
\hline 1945 & Organics in Whale Blubber & $2 \times 15 g$ \\
\hline 1946 & Lake Superior Fish Tissue & $5 \times 7-9 g$ \\
\hline 1947 & Lake Michigan Fish Tissue & $5 \times 8 g$ \\
\hline 1953 & $\begin{array}{l}\text { Organic Contaminants in } \\
\text { Non-Fortified Human Milk }\end{array}$ & $5 \times 5 \mathrm{~mL}$ \\
\hline 1954 & $\begin{array}{l}\text { Organic Contaminants in } \\
\text { Fortified Human Milk }\end{array}$ & $5 \times 5 \mathrm{~mL}$ \\
\hline 1957 & $\begin{array}{l}\text { Organic Contaminants in } \\
\text { Non-Fortified Human Serum (Freeze } \\
\text { Dried) }\end{array}$ & $5 \times 10 \mathrm{~mL}$ \\
\hline 1958 & $\begin{array}{l}\text { Organic Contaminants in } \\
\text { Fortified Human Serum (Freeze Dried) }\end{array}$ & $5 \times 10 \mathrm{~mL}$ \\
\hline $1974 c$ & $\begin{array}{l}\text { Organics in Mussel Tissue } \\
\text { (Mytilus edulis) }\end{array}$ & $5 \times 10 \mathrm{~g}$ \\
\hline 1975 & Diesel Particulate Extract & $4 \times 1.2 \mathrm{~mL}$ \\
\hline 1991 & $\begin{array}{l}\text { Mix Coal Tar/Petroleum Extract } \\
\text { in Methylene Chloride }\end{array}$ & $5 \times 1.2 \mathrm{~mL}$ \\
\hline 2257 & PBDE Congeners in 2,2,4-Trimethylpentane & $5 \times 1.2 \mathrm{~mL}$ \\
\hline 2258 & BDE 209 in 2,2,4-Trimethylpentane & $5 \times 1.2 \mathrm{~mL}$ \\
\hline
\end{tabular}

\begin{tabular}{|c|c|c|}
\hline SRM & Description & $\begin{array}{l}\text { Unit of } \\
\text { Issue }\end{array}$ \\
\hline 2259 & PCB Congeners in 2,2,4-Trimethylpentane & $5 \times 1.2 \mathrm{~mL}$ \\
\hline $2260 a$ & Aromatic Hydrocarbon in Toluene & $5 \times 1.2 \mathrm{~mL}$ \\
\hline 2261 & Chlorinated Pesticides in Hexane & $5 \times 1.2 \mathrm{~mL}$ \\
\hline 2262 & $\begin{array}{l}\text { Chlorinated Biphenyl Cogeners } \\
\text { in Isooctane }\end{array}$ & $5 \times 1.2 \mathrm{~mL}$ \\
\hline 2266 & $\begin{array}{l}\text { Hopanes and Steranes in, } \\
\text { 2,2,4 Trimethylpentane }\end{array}$ & $5 \times 1.2 \mathrm{~mL}$ \\
\hline 2269 & $\begin{array}{l}\text { Perdeuterated PAH-I Solution } \\
\text { in Hexane/Toluene }\end{array}$ & $5 \times 1.2 \mathrm{~mL}$ \\
\hline 2270 & $\begin{array}{l}\text { Perdeuterated PAH-II Solution } \\
\text { in Hexane/Toluene }\end{array}$ & $5 \times 1.2 \mathrm{~mL}$ \\
\hline 2273 & $\begin{array}{l}\text { Chlorinated Pesticides (DDTs) } \\
\text { and Metabolites in Isooctane }\end{array}$ & $5 \times 1.2 \mathrm{~mL}$ \\
\hline 2274 & PCB Congener Solution-II in Isooctane & $5 \times 1.2 \mathrm{~mL}$ \\
\hline 2275 & $\begin{array}{l}\text { Chlorinated Pesticide Solution-II } \\
\text { in Isooctane }\end{array}$ & $5 \times 1.2 \mathrm{~mL}$ \\
\hline 2377 & $\begin{array}{l}\text { Fatty Acid Methyl Esters in } \\
\text { 2,2,4-Trimethylpentane }\end{array}$ & $5 \times 1.2 \mathrm{~mL}$ \\
\hline 2585 & Organic Contaminants in House Dust & $10 \mathrm{~g}$ \\
\hline 2779 & Gulf of Mexico Crude Oil & $5 \times 1.2 \mathrm{~mL}$ \\
\hline 2781 & Domestic Sludge & $40 \mathrm{~g}$ \\
\hline 2786 & Fine Particulate Matter $(<4 \mu \mathrm{m})$ & 1 bottle \\
\hline 2787 & Fine Particulate Matter $(<10 \mu \mathrm{m})$ & 1 bottle \\
\hline $2974 a$ & $\begin{array}{l}\text { Organics in Freeze-Dried Mussel Tissue } \\
\text { (Mytilus edulis) }\end{array}$ & $5 \mathrm{~g}$ \\
\hline 2975 & Diesel Particulate Matter & $1 \mathrm{~g}$ \\
\hline 3060 & Monoester Phthalates in Acetonitrile & $5 \times 1.2 \mathrm{~mL}$ \\
\hline 3257 & Catechin Calibration Solutions & $12 \times 2 \mathrm{~mL}$ \\
\hline 3262 & $\begin{array}{l}\text { St. John's Wort (Hypericum perforatum L.) } \\
\text { Aerial Parts }\end{array}$ & $5 \times 3.3 \mathrm{~g}$ \\
\hline 3264 & $\begin{array}{l}\text { St. John's Wort (Hypericum perforatum L.) } \\
\text { Methanol Extract }\end{array}$ & $5 \times 1.6 \mathrm{~g}$ \\
\hline 3672 & $\begin{array}{l}\text { Organic Contaminants } \\
\text { in Smokers' Urine (Frozen) }\end{array}$ & $5 \times 10 \mathrm{~mL}$ \\
\hline 3673 & $\begin{array}{l}\text { Organic Contaminants } \\
\text { in Non-Smokers' Urine (Frozen) }\end{array}$ & $5 \times 10 \mathrm{~mL}$ \\
\hline 8446 & $\begin{array}{l}\text { Perfluorinated Carboxylic Acids and } \\
\text { Perfluorooctane Sulfonamide in Methanol }\end{array}$ & $4 \times 1.2 \mathrm{~mL}$ \\
\hline 8447 & Perfluorinated Sulfonic Acids in Methanol & $3 \times 1.2 \mathrm{~mL}$ \\
\hline
\end{tabular}

See Table 109.1 on the website for more information. 


\section{EPA: Organic Compounds \\ Related to Water Analysis (including drinking water)}

These SRMs are intended primarily for the calibration of instrumentation and validation of methods for volatile or semi-volatile organic compound determinations. Because of its miscibility with water, each SRM can also be used to fortify aqueous samples with known amounts of the organic compound. These SRMs were developed primarily to support the Chemical Calibration Providers of the Proficiency Testing Program with support by the U.S. Environmental Protection Agency (EPA).

\begin{tabular}{|l|l|c|}
\hline SRM & Description & $\begin{array}{c}\text { Unit of } \\
\text { Issue }\end{array}$ \\
\hline $\mathbf{3 0 7 4}$ & Phthalates in Methanol & $5 \times 1.2 \mathrm{~mL}$ \\
\hline $\mathbf{3 0 7 7}$ & Aroclor 1242 in Transformer Oil & $5 \times 1.2 \mathrm{~mL}$ \\
\hline $\mathbf{3 0 7 9}$ & Aroclor 1254 in Transformer Oil & $5 \times 1.2 \mathrm{~mL}$ \\
\hline $\mathbf{3 0 8 0}$ & Aroclor 1260 in Transformer Oil & $5 \times 1.2 \mathrm{~mL}$ \\
\hline $\mathbf{8 5 0 4}$ & Transformer Oil & $100 \mathrm{~mL}$ \\
\hline
\end{tabular}

See Table 109.3 on the website for more information.

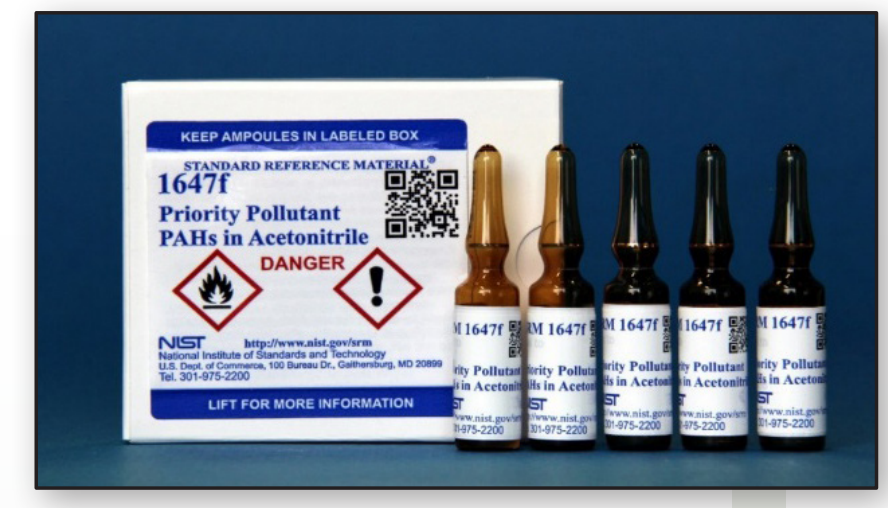

\section{Perfluorinated and Polyfluorinated Alkyl Substances (PFAS)}

\begin{tabular}{|c|c|c|}
\hline SRM & Description & $\begin{array}{l}\text { Unit of } \\
\text { Issue }\end{array}$ \\
\hline 1946 & Lake Superior Fish Tissue & $5 \times 7-9 g$ \\
\hline 1947 & Lake Michigan Fish Tissue & $5 \times 8 g$ \\
\hline 1957 & $\begin{array}{l}\text { Organic Contaminants in Non-fortified } \\
\text { Human Serum (Freeze-Dried) }\end{array}$ & $5 \times 10.7 \mathrm{~mL}$ \\
\hline 1958 & $\begin{array}{l}\text { Organic Contaminants in Fortified } \\
\text { Human Serum (Freeze-Dried) }\end{array}$ & $5 \times 10 \mathrm{~mL}$ \\
\hline 2781 & Domestic Sludge & $40 \mathrm{~g}$ \\
\hline 8446 & $\begin{array}{l}\text { Perfluorinated Carboxylic Acids and } \\
\text { Perfluorooctane Sulfonamide in Methanol }\end{array}$ & $4 \times 1.2 \mathrm{~mL}$ \\
\hline 8447 & Perfluorinated Sulfonic Acids in Methanol & $3 \times 1.2 \mathrm{~mL}$ \\
\hline
\end{tabular}

See Table 109.5 on the website for more information.

\section{Crime Scene Investigations}

SRM 2285 is intended primarily for use in the calibration of chromatographic instrumentation used for the classification of an ignitable liquid residue. This SRM is a solution of 15 compounds, including even carbon number aliphatic hydrocarbons from hexane to tetracosane, toluene, $p$-xylene, 2-ethyltoluene, 3-ethyltoluene, and 1,2,4-trimethylbenzene in methylene chloride.

\begin{tabular}{|l|l|c|}
\hline SRM & Description & $\begin{array}{c}\text { Unit of } \\
\text { Issue }\end{array}$ \\
\hline $\mathbf{2 2 8 5}$ & Ignitable Liquids Test Mixture & $5 \times 1.2 \mathrm{~mL}$ \\
\hline $\mathbf{2 4 6 0}$ & Standard Bullet & each \\
\hline $\mathbf{2 4 6 1}$ & Standard Cartridge Case & each \\
\hline $\mathbf{2 9 0 5}$ & Trace Terrorist Explosives Simulants & $4 \times 1 \mathrm{~g}$ \\
\hline $\mathbf{2 9 0 7}$ & Trace Terrorist Explosives Simulants & $2 \times 1 \mathrm{~g}$ \\
\hline
\end{tabular}

See Table 109.4 on the website for more information. 

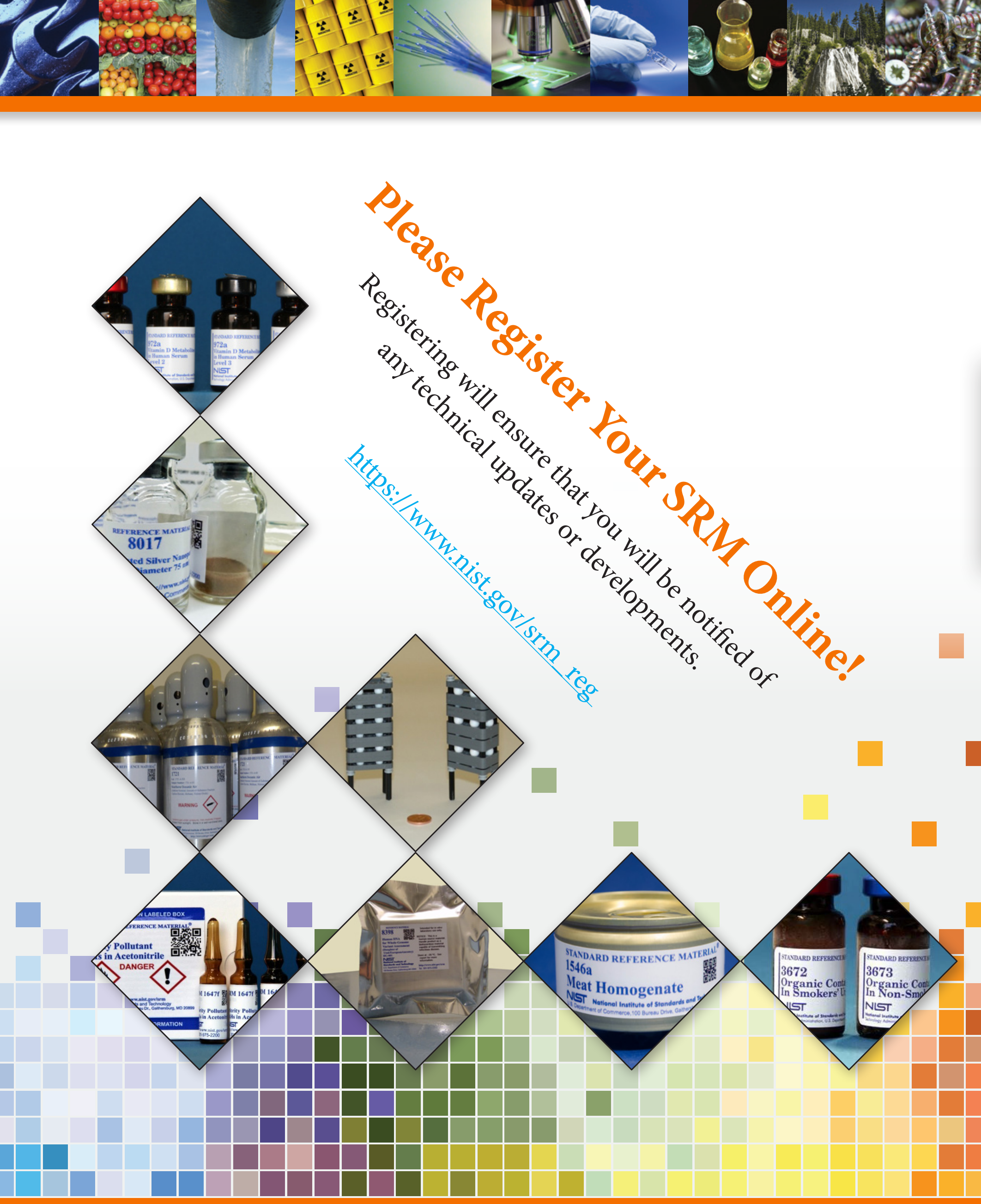

www.nist.gov/srm | Phone: 301.975.2200 | Fax: 301.948.3730 | Email: srminfo@nist.gov 


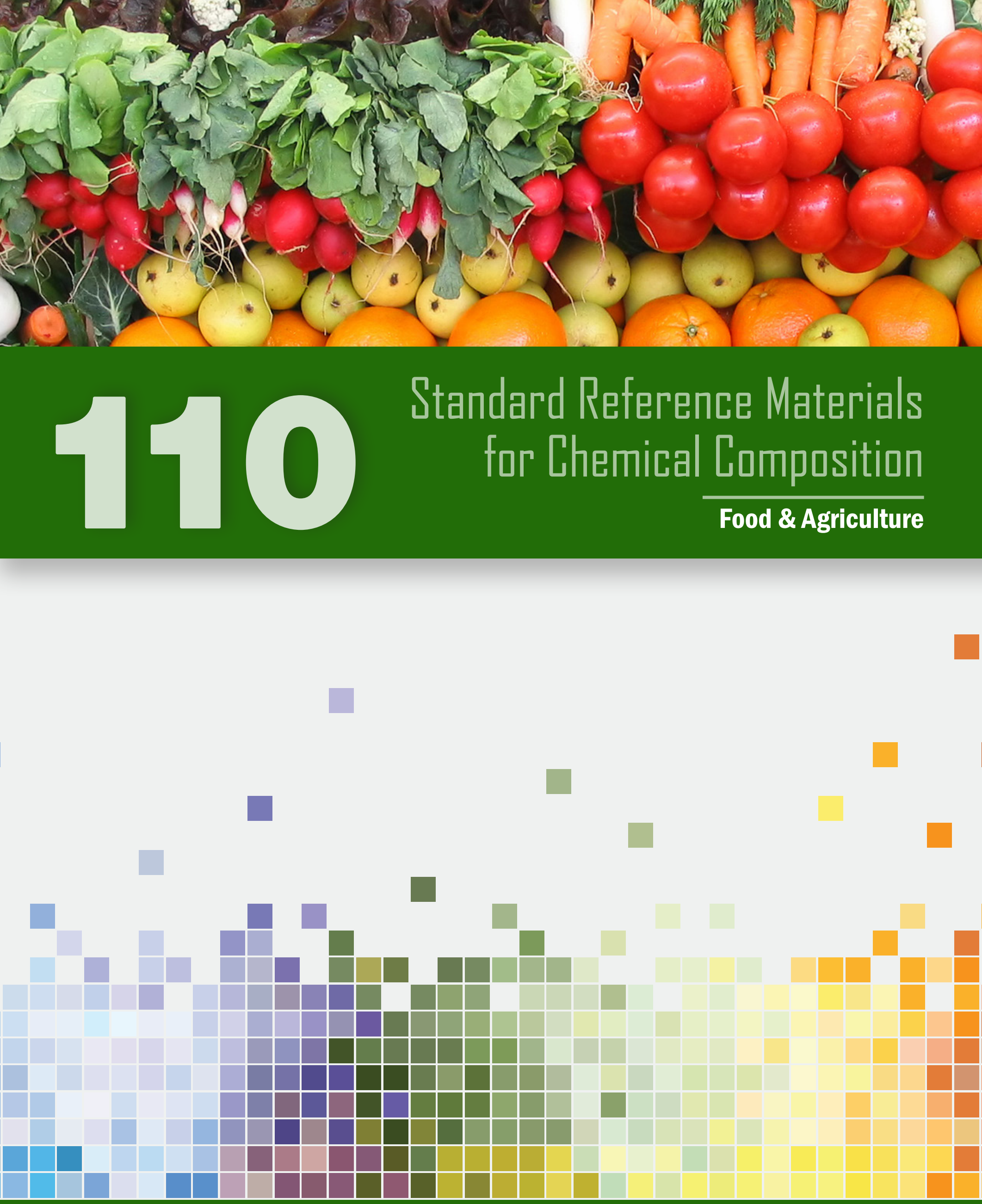




\section{Foods and Beverages}

These SRMs are for validation of analytical procedures and calibration of apparatus used in the analysis of trace elements and other analytes in foods and related products.

\begin{tabular}{|c|c|c|}
\hline SRM & Description & $\begin{array}{l}\text { Unit of } \\
\text { Issue }\end{array}$ \\
\hline $1546 a$ & Meat Homogenate & $4 \times 85 \mathrm{~g}$ \\
\hline $1548 \mathrm{a}$ & Typical Diet & set $(2)$ \\
\hline $1549 \mathrm{a}$ & Whole Milk Powder & $5 \times 10 \mathrm{~g}$ \\
\hline $1566 b$ & Oyster Tissue & $25 \mathrm{~g}$ \\
\hline $1567 \mathrm{~b}$ & Wheat Flour & $50 \mathrm{~g}$ \\
\hline $1568 b$ & Rice Flour & $50 \mathrm{~g}$ \\
\hline $1570 \mathrm{a}$ & Trace Elements in Spinach Leaves & $60 \mathrm{~g}$ \\
\hline $1577 \mathrm{c}$ & Bovine Liver & $20 \mathrm{~g}$ \\
\hline $1845 a$ & Whole Egg Powder & $5 \times 10 \mathrm{~g}$ \\
\hline $1849 a$ & Infant/Adult Nutritional Formula & $10 \times 10 \mathrm{~g}$ \\
\hline 1946 & Lake Superior Fish Tissue & $5 \times 7-9 g$ \\
\hline 1947 & Lake Michigan Fish Tissue & $5 \times 8 g$ \\
\hline $2383 a$ & Baby Food Composite & $4 \times 70 \mathrm{~g}$ \\
\hline 2384 & Baking Chocolate & $5 \times 91 \mathrm{~g}$ \\
\hline 2385 & Slurried Spinach & $4 \times 70 \mathrm{~g}$ \\
\hline 3035 & Arsenic Species in Apple Juice & $5 \times 1.5 \mathrm{~mL}$ \\
\hline 3233 & Fortified Breakfast Cereal & $60 \mathrm{~g}$ \\
\hline 3234 & Soy Flour & $50 \mathrm{~g}$ \\
\hline 3252 & Protein Drink Mix & $5 \times 10 \mathrm{~g}$ \\
\hline 3254 & Green Tea (Camellia sinensis) Leaves & $5 \times 3 g$ \\
\hline 3255 & Green Tea (Camellia sinensis) Extract & $5 \times 1 g$ \\
\hline 3278 & Tocopherols in Edible Oils & $5 \times 1 \mathrm{~mL}$ \\
\hline 3281 & Cranberry (Fruit) & $5 \times 6 g$ \\
\hline 3282 & Low-Calorie Cranberry Juice Cocktail & $5 \times 1.2 \mathrm{~mL}$ \\
\hline 3287 & Blueberry (Fruit) & $5 \times 5 g$ \\
\hline 3290 & Dry Cat Food & $5 \times 10 \mathrm{~g}$ \\
\hline 3530 & Iodized Table Salt (Iodide) & $1 \times 200 \mathrm{~g}$ \\
\hline
\end{tabular}

See Table 110.1 on the website for more information.
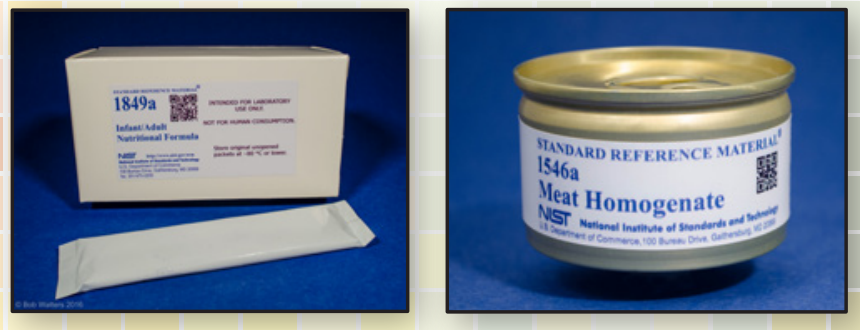

\section{Food Contaminants and Allergens}

\begin{tabular}{|l|l|c|}
\hline SRM & Description & $\begin{array}{c}\text { Unit of } \\
\text { Issue }\end{array}$ \\
\hline $\mathbf{1 5 6 6 b}$ & Oyster Tissue & $25 \mathrm{~g}$ \\
\hline $\mathbf{1 9 4 6}$ & Lake Superior Fish Tissue & $5 \times 7-9 \mathrm{~g}$ \\
\hline $\mathbf{1 9 4 7}$ & Lake Michigan Fish Tissue & $5 \times 8 \mathrm{~g}$ \\
\hline $\mathbf{1 9 5 3}$ & $\begin{array}{l}\text { Organic Contaminants in Non- } \\
\text { Fortified Human Milk }\end{array}$ & $5 \times 5 \mathrm{~mL}$ \\
\hline $\mathbf{1 9 5 4}$ & $\begin{array}{l}\text { Organic Contaminants } \\
\text { in Fortified Human Milk }\end{array}$ & $5 \times 5 \mathrm{~mL}$ \\
\hline $\mathbf{2 3 8 7}$ & \begin{tabular}{l} 
Peanut Butter \\
\hline $\mathbf{3 2 5 6}$
\end{tabular} & $\begin{array}{l}\text { Green Tea-Containing Solid } \\
\text { Oral Dosage Form }\end{array}$ \\
\hline $\mathbf{8 4 4 5}$ & $\begin{array}{l}\text { Spray-Dried Whole Egg for } \\
\text { Allergen Detection }\end{array}$ & $5 \times 2.5 \mathrm{~g}$ \\
\hline $\mathbf{8 6 4 2 a}$ & FDA Saxitoxin Dihydrochloride Solution & $5 \times 1.2 \mathrm{~mL}$ \\
\hline
\end{tabular}

See Table 110.2 on the website for more information.

\section{Agricultural Materials (powder form)}

\begin{tabular}{|l|l|c|}
\hline SRM & Description & $\begin{array}{c}\text { Unit of } \\
\text { Issue }\end{array}$ \\
\hline $\mathbf{1 5 1 5}$ & Apple Leaves & $50 \mathrm{~g}$ \\
\hline $\mathbf{1 5 4 7}$ & Peach Leaves & $50 \mathrm{~g}$ \\
\hline $\mathbf{1 5 7 0 a}$ & Trace Elements in Spinach Leaves & $60 \mathrm{~g}$ \\
\hline $\mathbf{1 5 7 3 a}$ & Tomato Leaves & $50 \mathrm{~g}$ \\
\hline $\mathbf{1 5 7 5 a}$ & Trace Elements in Pine Needles & $50 \mathrm{~g}$ \\
\hline
\end{tabular}

See Table 110.4 on the website for more information.

\section{Fertilizers (powder form)}

These SRMs are intended for use in the fertilizer industry as working standards.

\begin{tabular}{|l|l|c|}
\hline SRM & Description & $\begin{array}{c}\text { Unit of } \\
\text { Issue }\end{array}$ \\
\hline 120c & Phosphate Rock (Florida) & $90 \mathrm{~g}$ \\
\hline $\mathbf{1 9 3}$ & Potassium Nitrate & $90 \mathrm{~g}$ \\
\hline $\mathbf{1 9 4 a}$ & $\begin{array}{l}\text { Ammonium Dihydrogen Phosphate } \\
\text { (Fertilizer Standard) }\end{array}$ & $90 \mathrm{~g}$ \\
\hline $\mathbf{2 0 0 b}$ & Potassium Dihydrogen Phosphate, $\left(\mathrm{KH}_{2} \mathrm{PO}_{4}\right)$ & $90 \mathrm{~g}$ \\
\hline $\mathbf{6 9 4}$ & Phosphate Rock, Western & $90 \mathrm{~g}$ \\
\hline $\mathbf{6 9 5}$ & $\begin{array}{l}\text { Trace Elements in Multi-Nutrient } \\
\text { Fertilizer }\end{array}$ & $70 \mathrm{~g}$ \\
\hline $\mathbf{2 4 2 9}$ & Flue Gas Desulfurization Gypsum & $200 \mathrm{~g}$ \\
\hline
\end{tabular}

See Table 110.5 on the website for more information. 


\section{Wheat Hardness (kernel form)}

This RM is intended primarily for calibrating instruments used to determine the hardness of bulk or single kernel wheat. RM 8441 was prepared and analyzed by the Federal Grain Inspection Service program, Grain Inspection Packers and Stockyards Administration of the United States Department of Agriculture.'

\begin{tabular}{|l|l|c|}
\hline SRM & Description & $\begin{array}{c}\text { Unit of } \\
\text { Issue }\end{array}$ \\
\hline 8441a & Wheat Hardness & set $(50)$ \\
\hline
\end{tabular}

See Table 110.6 on the website for more information.

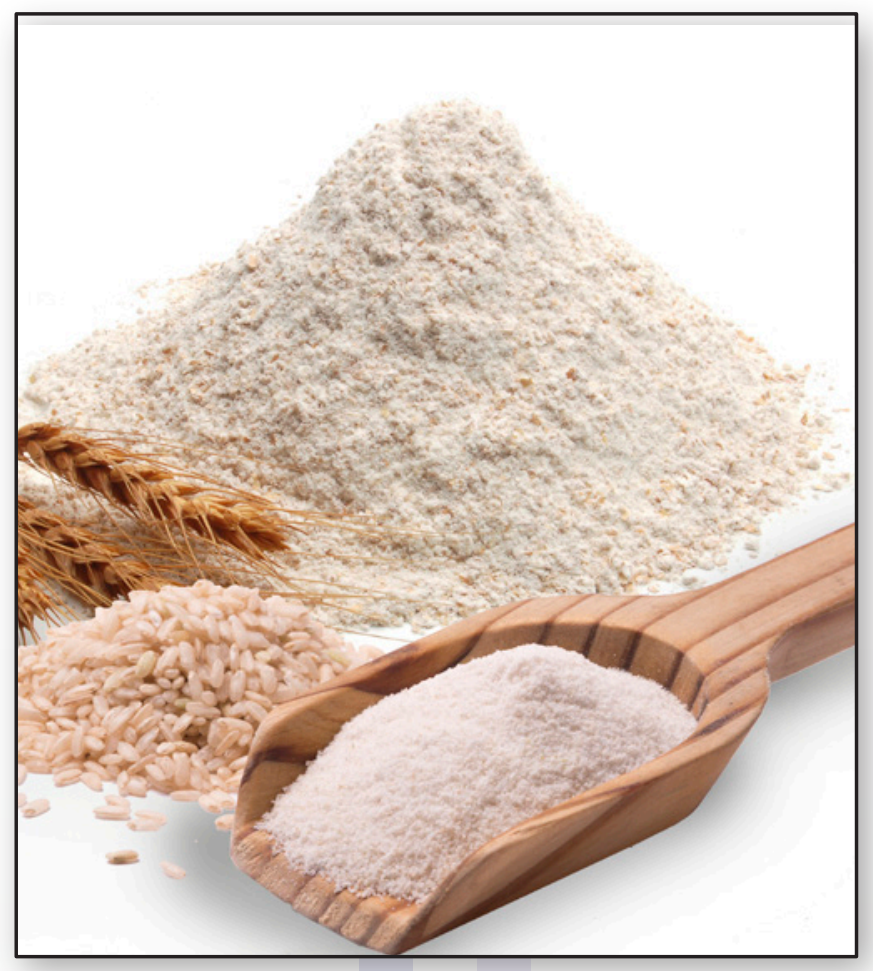

\section{Tobacco Related Materials}

\begin{tabular}{|l|l|c|}
\hline SRM & Description & $\begin{array}{c}\text { Unit of } \\
\text { Issue }\end{array}$ \\
\hline $\mathbf{3 2 2 2}$ & Cigarette Tobacco Filler & $20 \times 10 \mathrm{~g}$ \\
\hline
\end{tabular}

See Table 110.10 on the website for more information.

\section{Dietary Supplement Materials (includes nutraceuticals and herbs)}

\begin{tabular}{|c|c|c|}
\hline SRM & Description & $\begin{array}{l}\text { Unit of } \\
\text { Issue }\end{array}$ \\
\hline 3232 & Kelp Powder (Thallus laminariae) & $3 \times 5 g$ \\
\hline 3235 & Soy Milk & $10 \times 10 \mathrm{~mL}$ \\
\hline 3236 & Soy Protein Isolate & $5 \times 10 \mathrm{~g}$ \\
\hline 3237 & Soy Protein Concentrate & $5 \times 10 \mathrm{~g}$ \\
\hline 3238 & Soy-Containing Solid Oral Dosage Form & $5 \times 10 \mathrm{~g}$ \\
\hline 3239 & Isoflavones Calibration Solutions & $10 \times 1.2 \mathrm{~mL}$ \\
\hline 3246 & Ginkgo biloba (Leaves) & $5 \times 3 g$ \\
\hline 3247 & Ginkgo biloba (Extract) & $5 \times 1 g$ \\
\hline 3248 & Ginkgo-Containing Tablets & $5 \times 1 g$ \\
\hline 3250 & Saw Palmetto (Serenoa repens) Fruit & $5 \times 6 g$ \\
\hline 3251 & Saw Palmetto (Serenoa repens) Extract & $5 \times 1 \mathrm{~mL}$ \\
\hline 3254 & Green Tea (Camellia sinensis) Leaves & $5 \times 3 g$ \\
\hline 3255 & Green Tea (Camellia sinensis) Extract & $5 \times 1 g$ \\
\hline 3256 & $\begin{array}{l}\text { Green Tea-Containing Solid Oral } \\
\text { Dosage Form }\end{array}$ & $5 \times 2.5 \mathrm{~g}$ \\
\hline 3257 & Catechin Calibration Solutions & $12 \times 2 \mathrm{~mL}$ \\
\hline 3262 & $\begin{array}{l}\text { St. John's Wort (Hypericum perforatum L.) } \\
\text { Aerial Parts }\end{array}$ & $5 \times 3.3 \mathrm{~g}$ \\
\hline 3264 & $\begin{array}{l}\text { St. John's Wort (Hypericum perforatum L.) } \\
\text { Methanol Extract }\end{array}$ & $5 \times 1.6 \mathrm{~g}$ \\
\hline 3274 & $\begin{array}{l}\text { Botanical Oils Containing Omega-3 } \\
\text { and Omega-6 Fatty Acids }\end{array}$ & $4 \times 1.2 \mathrm{~mL}$ \\
\hline 3275 & $\begin{array}{l}\text { Omega- } 3 \text { and Omega- } 6 \text { Fatty Acids } \\
\text { in Fish Oil }\end{array}$ & $\begin{array}{c}3 \mathrm{ea} \\
(2 \times 1.2 \mathrm{~mL})\end{array}$ \\
\hline 3280 & Multivitamin/Multielement Tablets & $\begin{array}{l}30 \times 5 \\
\text { bottles }\end{array}$ \\
\hline 3281 & Cranberry (Fruit) & $5 \times 6 g$ \\
\hline 3282 & Low-Calorie Cranberry Juice Cocktail & $5 \times 1.2 \mathrm{~mL}$ \\
\hline 3283 & Cranberry Extract & $5 \times 2.5 \mathrm{~g}$ \\
\hline 3284 & $\begin{array}{l}\text { Cranberry-Containing Solid Oral } \\
\text { Dosage Form }\end{array}$ & $5 \times 2.5 \mathrm{~g}$ \\
\hline 3285 & $\begin{array}{l}\text { Mixed-Berry Containing Solid Oral } \\
\text { Dosage Form }\end{array}$ & $5 \times 2.5 \mathrm{~g}$ \\
\hline 3286 & Organic Acids Calibration Solution & $5 \times 2 \mathrm{~mL}$ \\
\hline 3291 & Bilberry Extract & $5 \times 1 \mathrm{~g}$ \\
\hline 3530 & Iodized Table Salt (Iodide) & $1 \times 200 \mathrm{~g}$ \\
\hline 3532 & $\begin{array}{l}\text { Calcium-Containing Solid Oral } \\
\text { Dosage Form }\end{array}$ & $5 \times 10 \mathrm{~g}$ \\
\hline
\end{tabular}

See Table 110.9 on the website for more information. 


\section{Distribution of SRMs in the AOAC Food Triangle}

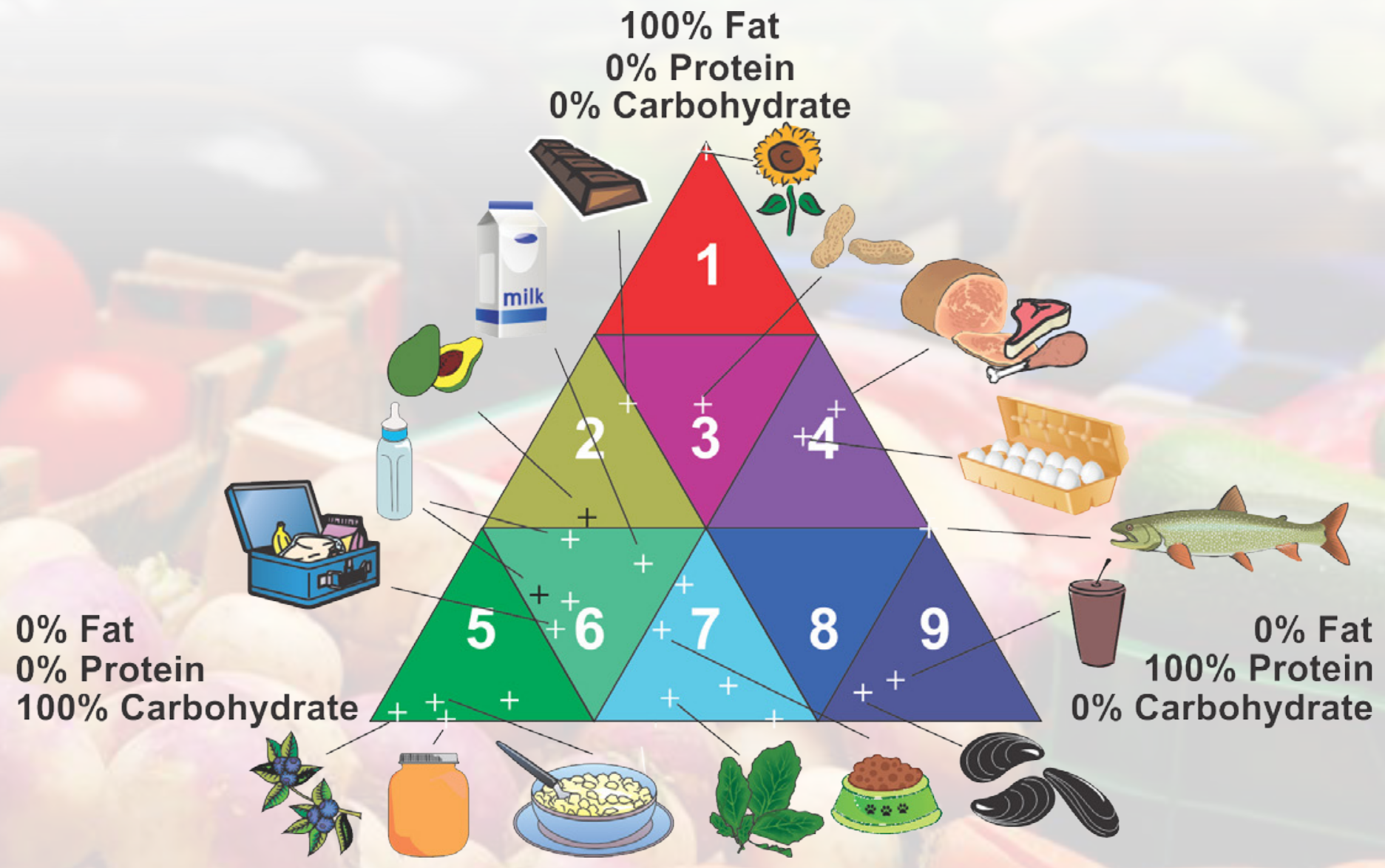

NIST classifies food-matrix SRMs based on fat, protein, and carbohydrate content using a triangle developed by AOAC INTERNATIONAL1, based on the supposition that foods (and thus reference materials) within each sector will have similar properties and therefore will pose similar challenges in determination of the same nutrient. Preparation of food-matrix SRMs has been based on the distribution of foods from a typical US diet in the AOAC triangle, with a majority of common foods and SRMs categorized in sectors 5 and 6 (e.g., fruits, vegetables, cereals, and grains). Conversely, only a small fraction of foods and SRMs are categorized in sectors 1 through 4 (higher-fat foods like meats and nuts). Additional materials are also prepared based on suggestions from user communities.

$1 \quad$ SRM 1588c Organics in Fish Oil SRM 3274 Fatty Acids in Botanical Oils SRM 3275 Fatty Acids in Fish Oils

SRM 2384 Baking Chocolate

SRM 2386 Avocado Powder*

3 SRM 2387 Peanut Butter

4 SRM 1546a Meat Homogenate

SRM 1845a Whole Egg Powder

5 SRM 1568b Rice Flour

SRM 2383a Baby Food Composite

SRM 3233 Fortified Breakfast Cereal

SRM 3287 Blueberries

SRM 1869 Infant/Adult Nutritional Formula*
6 SRM 1544 Fatty Acids in Frozen Diet Composite SRM 1548a Typical Diet

SRM 1549a Whole Milk Powder

SRM 1849a Infant/Adult Nutritional Formula

7 SRM 1566b Oyster Tissue

SRM 2385 Slurried Spinach

SRM 3234 Soy Flour

SRM 3290 Dry Cat Food

9 SRM 1946 Lake Superior Fish Tissue SRM 1947 Lake Michigan Fish Tissue SRM 2974a Mussel Tissue

SRM 3252 Protein Drink Mix *in preparation

${ }^{1}$ WR Wolf, KW Andrews (1995) Fresenius J Anal Chem 352:73-76. 
Ores

(powder form)

\begin{tabular}{|c|c|c|}
\hline SRM & Description & $\begin{array}{l}\text { Unit of } \\
\text { Issue }\end{array}$ \\
\hline $25 d$ & Manganese Ore & $60 \mathrm{~g}$ \\
\hline $69 b$ & Bauxite (Arkansas) & $60 \mathrm{~g}$ \\
\hline $79 a$ & Fluorspar & $120 \mathrm{~g}$ \\
\hline $120 \mathrm{c}$ & Phosphate Rock (Florida) & $90 \mathrm{~g}$ \\
\hline 180 & Fluorspar, High Grade & $120 \mathrm{~g}$ \\
\hline 181 & Lithium Ore (Spodumene) & $45 \mathrm{~g}$ \\
\hline 182 & Lithium Ore (Petalite) & $45 \mathrm{~g}$ \\
\hline 183 & Lithium Ore (Lepidolite) & $45 \mathrm{~g}$ \\
\hline 277 & Tungsten Concentrate & $100 \mathrm{~g}$ \\
\hline $330 a$ & Copper Ore Mill Heads & $90 \mathrm{~g}$ \\
\hline $331 \mathrm{a}$ & Copper Ore Mill Tails & $40 \mathrm{~g}$ \\
\hline $333 a$ & Molybdenum Sulfide Concentrate & $60 \mathrm{~g}$ \\
\hline 423 & Molybdenum Oxide Concentrate & $60 \mathrm{~g}$ \\
\hline 600 & Bauxite, Australian-Darling Range & $90 \mathrm{~g}$ \\
\hline 670 & Rutile Ore & $90 \mathrm{~g}$ \\
\hline 690 & Iron Ore Canada & $100 \mathrm{~g}$ \\
\hline 691 & Iron Oxide, Reduced & $100 \mathrm{~g}$ \\
\hline 692 & Iron Ore, Labrador & $100 \mathrm{~g}$ \\
\hline 693 & Iron Ore (Nimba) & $100 \mathrm{~g}$ \\
\hline 694 & Phosphate Rock, Western & $90 \mathrm{~g}$ \\
\hline 696 & Bauxite, Surinam & $60 \mathrm{~g}$ \\
\hline 697 & Bauxite, Dominican & $60 \mathrm{~g}$ \\
\hline 698 & Bauxite, Jamaican & $60 \mathrm{~g}$ \\
\hline 699 & Alumina (Reduction Grade) & $60 \mathrm{~g}$ \\
\hline 886 & Refractory Gold Ore & $200 \mathrm{~g}$ \\
\hline 1835 & Borate Ore & $60 \mathrm{~g}$ \\
\hline 2430 & Scheelite Ore & $100 \mathrm{~g}$ \\
\hline
\end{tabular}

See Table 111.2 on the website for more information.

\section{Ore Bioleaching Substrate (powder form)}

This RM is for use as a bioleaching substrate and for testing bioleaching rates. The material consists of pyrite from New Mexico. Thiobacillus ferrooxidans was used in the determinations.

\begin{tabular}{|l|l|c|}
\hline SRM & Description & $\begin{array}{c}\text { Unit of } \\
\text { Issue }\end{array}$ \\
\hline $\mathbf{8 4 5 5}$ & Pyrite Ore Bioleaching Substrate & $100 \mathrm{~g}$ \\
\hline
\end{tabular}

See Table 111.3 on the website for more information.

\section{Clays \\ (powder form)}

\begin{tabular}{|l|l|c|}
\hline SRM & Description & $\begin{array}{c}\text { Unit of } \\
\text { Issue }\end{array}$ \\
\hline 97b & Flint Clay & $60 \mathrm{~g}$ \\
\hline 98b & Plastic Clay & $60 \mathrm{~g}$ \\
\hline $\mathbf{6 7 9}$ & Brick Clay & $75 \mathrm{~g}$ \\
\hline
\end{tabular}

See Table 111.4 on the website for more information.

\section{Rock and Minerals (powder form)}

\begin{tabular}{|l|l|c|}
\hline SRM & Description & $\begin{array}{c}\text { Unit of } \\
\text { Issue }\end{array}$ \\
\hline $\mathbf{1 d}$ & Limestone, Argillaceous & $70 \mathrm{~g}$ \\
\hline $\mathbf{7 0 b}$ & Potassium Feldspar & $40 \mathrm{~g}$ \\
\hline $\mathbf{8 1 a}$ & Glass Sand & $75 \mathrm{~g}$ \\
\hline $\mathbf{8 8 b}$ & Dolomitic Limestone & $75 \mathrm{~g}$ \\
\hline $\mathbf{9 9 b}$ & Soda Feldspar & $40 \mathrm{~g}$ \\
\hline $\mathbf{1 6 5 a}$ & Glass Sand & $75 \mathrm{~g}$ \\
\hline $\mathbf{2 7 8}$ & Obsidian Rock & $35 \mathrm{~g}$ \\
\hline $\mathbf{6 0 7}$ & Potassium Feldspar & $5 \mathrm{~g}$ \\
\hline $\mathbf{6 8 8}$ & Basalt Rock & $60 \mathrm{~g}$ \\
\hline $\mathbf{1 4 1 3}$ & High Alumina Sand & $75 \mathrm{~g}$ \\
\hline $\mathbf{2 4 2 9}$ & Flue Gas Desulfurization Gypsum & $200 \mathrm{~g}$ \\
\hline
\end{tabular}

See Table 111.5 on the website for more information.

\section{Refractories (powder form)}

\begin{tabular}{|l|l|c|}
\hline SRM & Description & $\begin{array}{c}\text { Unit of } \\
\text { Issue }\end{array}$ \\
\hline $\mathbf{7 6 a}$ & Burnt Refractory $\left(\mathrm{Al}_{2} \mathrm{O}_{3}-40 \%\right)$ & $75 \mathrm{~g}$ \\
\hline $\mathbf{7 7 a}$ & Burnt Refractory $\left(\mathrm{Al}_{2} \mathrm{O}_{3}-60 \%\right)$ & $75 \mathrm{~g}$ \\
\hline $\mathbf{7 8 a}$ & Burnt Refractory $\left(\mathrm{Al}_{2} \mathrm{O}_{3}-70 \%\right)$ & $75 \mathrm{~g}$ \\
\hline $\mathbf{1 5 4 c ^ { * * * }}$ & Titanium Dioxide & $90 \mathrm{~g}$ \\
\hline $\mathbf{1 9 8}$ & Silica Brick & $45 \mathrm{~g}$ \\
\hline $\mathbf{1 9 9}$ & Silica Brick & $45 \mathrm{~g}$ \\
\hline
\end{tabular}

*** Information values are provided for additional 71 elements See Table 111.6 on the website for more information. 
Soils, Sediments, and Sludges (powder form)

SRMs 2586, 2587, 2700 2701, 2709a, 2710a, 2711a, 2781, 2782 also have non-certified leach data. See certificate for details and leach methods used.

\begin{tabular}{|l|l|c|}
\hline SRM & Description & $\begin{array}{c}\text { Unit of } \\
\text { Issue }\end{array}$ \\
\hline $\mathbf{1 6 4 6 a}$ & Estuarine Sediment & $70 \mathrm{~g}$ \\
\hline $\mathbf{1 9 4 4}$ & New York/New Jersey Waterway Sediment & $50 \mathrm{~g}$ \\
\hline $\mathbf{2 5 8 6}$ & $\begin{array}{l}\text { Trace Elements in Soil Containing Lead } \\
\text { From Paint (Nominal 500 mg/kg Lead) }\end{array}$ & $55 \mathrm{~g}$ \\
\hline $\mathbf{2 5 8 7}$ & $\begin{array}{l}\text { Trace Elements in Soil Containing Lead } \\
\text { From Paint (Nominal 3000 mg/kg Lead) }\end{array}$ & $55 \mathrm{~g}$ \\
\hline $\mathbf{2 7 0 0}$ & $\begin{array}{l}\text { Hexavalent Chromium } \\
\text { in Contaminated Soil (Low Level) }\end{array}$ & $75 \mathrm{~g}$ \\
\hline $\mathbf{2 7 0 1}$ & $\begin{array}{l}\text { Hexavalent Chromium } \\
\text { in Contaminated Soil (High Level) }\end{array}$ & $75 \mathrm{~g}$ \\
\hline $\mathbf{2 7 0 2}$ & Inorganics in Marine Sediment & $50 \mathrm{~g}$ \\
\hline $\mathbf{2 7 0 3}$ & $\begin{array}{l}\text { Sediment for Solid Sampling } \\
\text { (Small Sample) Analytical Techniques }\end{array}$ & $5 \mathrm{~g}$ \\
\hline $\mathbf{2 7 0 9 a}$ & San Joaquin Soil & $50 \mathrm{~g}$ \\
\hline $\mathbf{2 7 1 0 a}$ & Montana I Soil & $50 \mathrm{~g}$ \\
\hline $\mathbf{2 7 1 1 a}$ & Montana II Soil & $50 \mathrm{~g}$ \\
\hline $\mathbf{2 7 8 0}$ & Hard Rock Mine Waste & $50 \mathrm{~g}$ \\
\hline $\mathbf{2 7 8 1}$ & Domestic Sludge & $40 \mathrm{~g}$ \\
\hline $\mathbf{2 7 8 2}$ & Industrial Sludge \\
\hline $\mathbf{8 7 0 4}$ & Buffalo River Sediment \\
\hline $\mathbf{2 0 e}$ & $\mathbf{7}$ g & \\
\hline
\end{tabular}

See Table 111.7 on the website for more information.

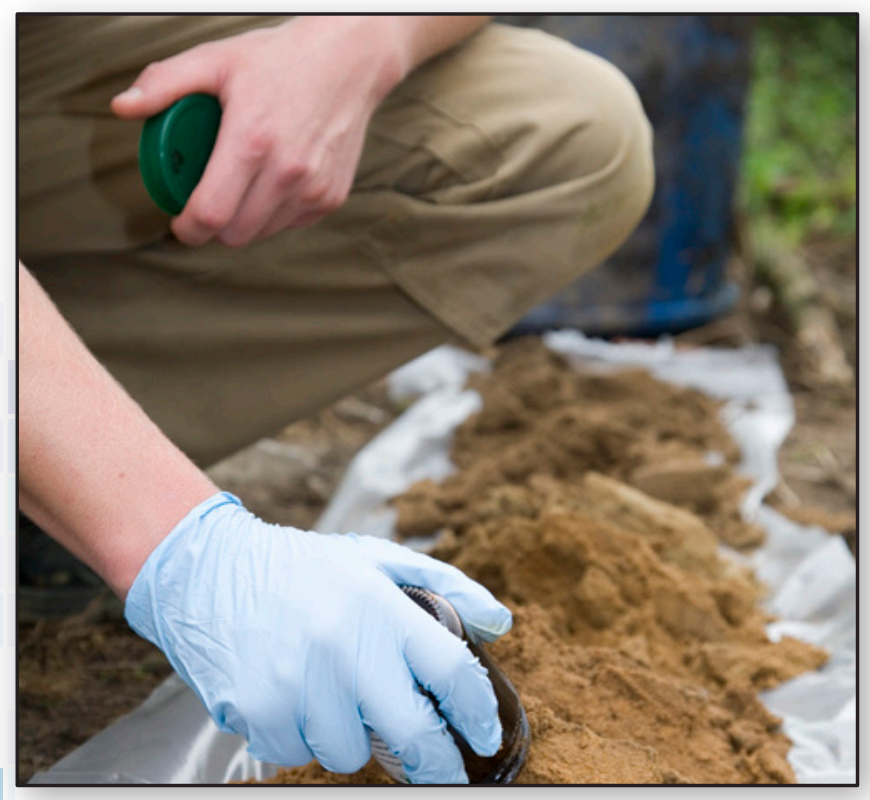

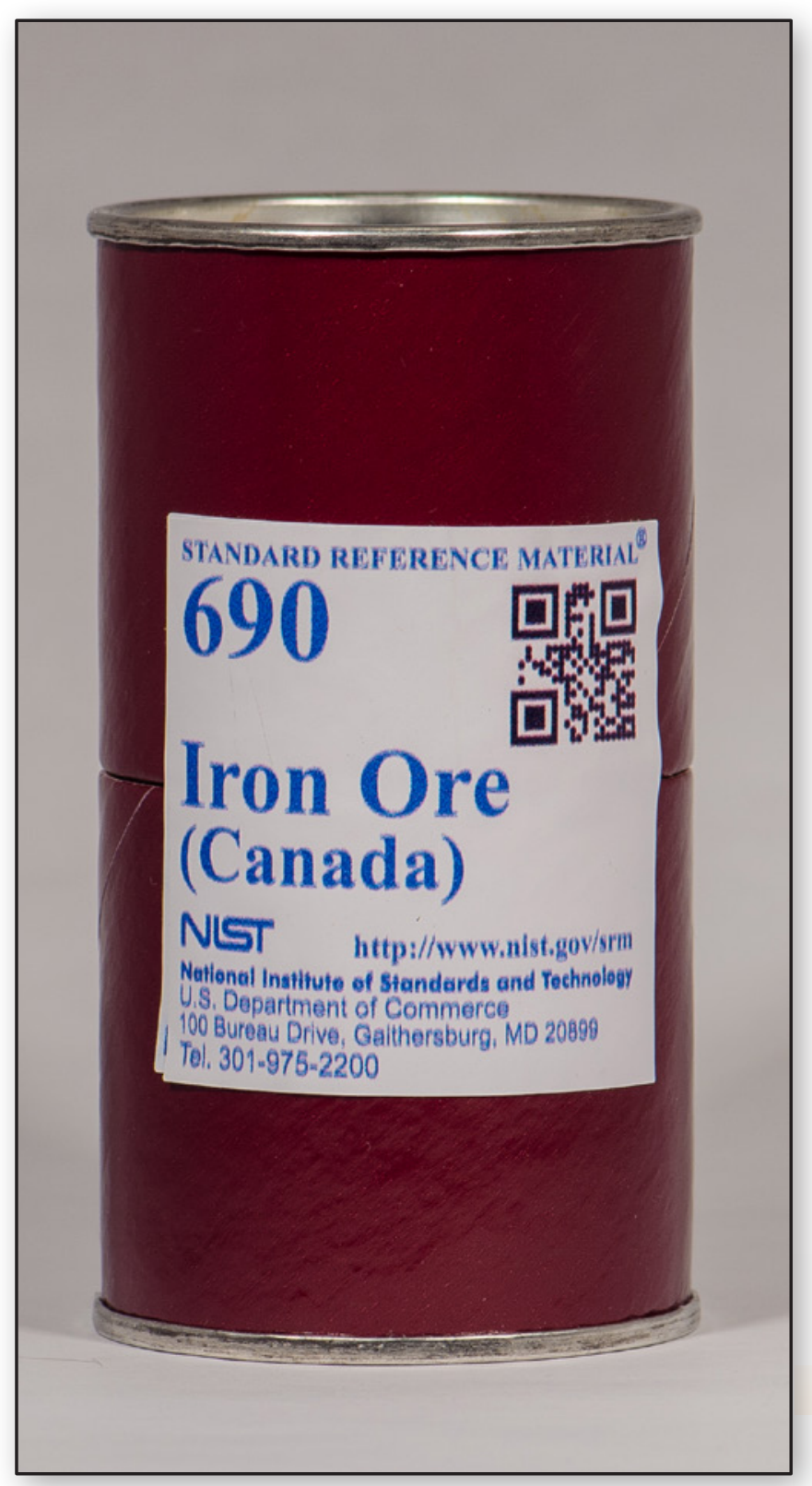


This page was intentionally left blank.

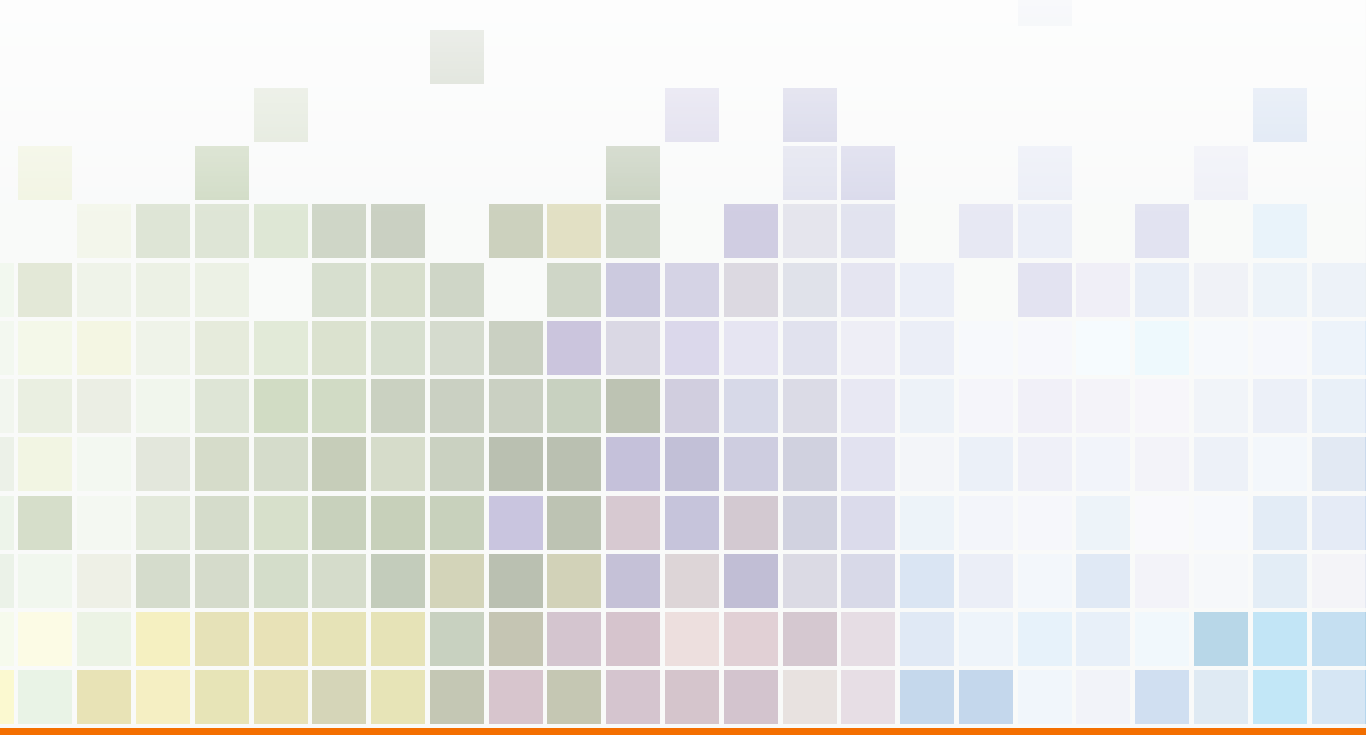



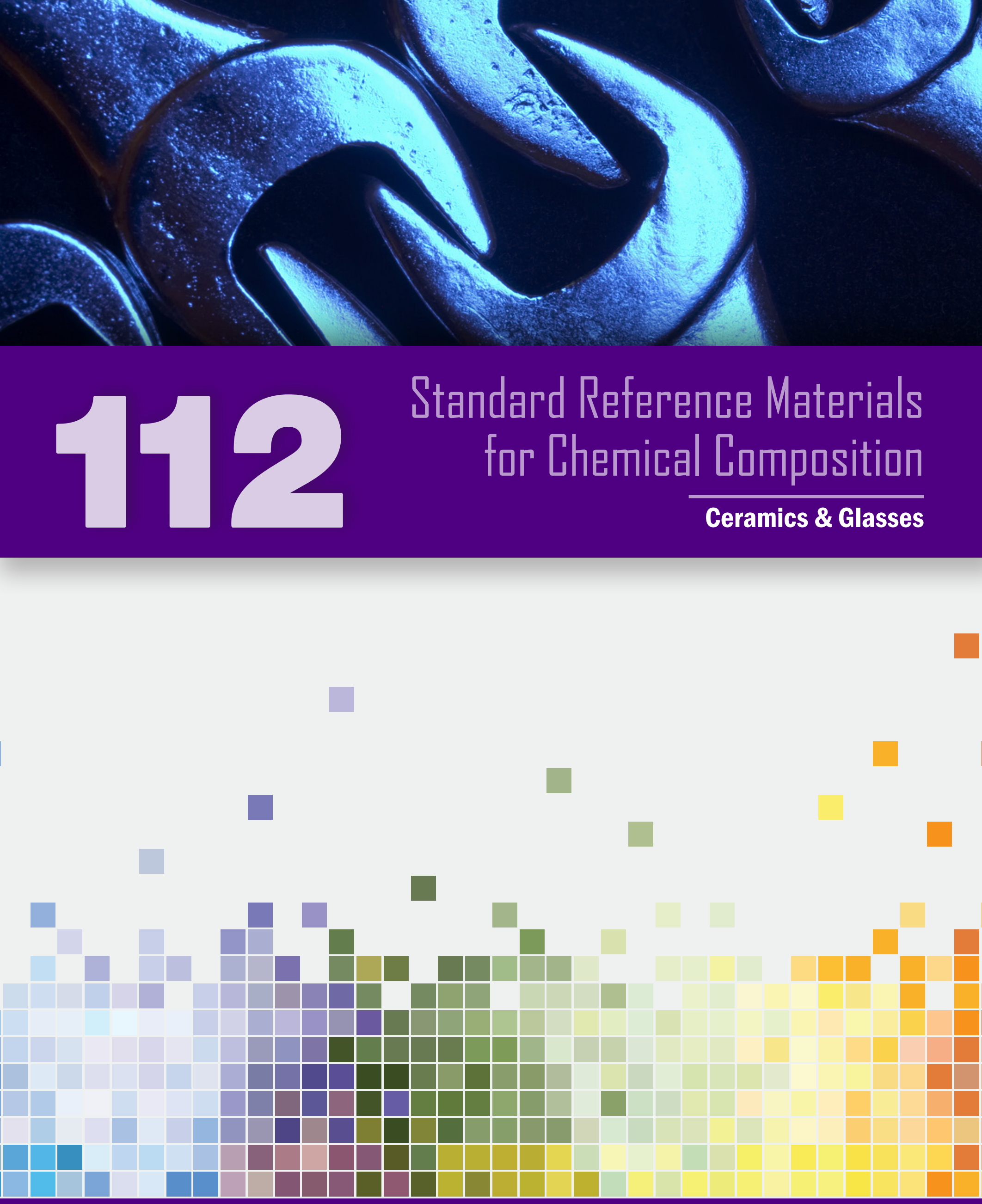

www.nist.gov/srm | Phone: 301.975.2200 | Fax: 301.948.3730 | Email: srminfo@nist.gov 
Nitrides

(powder form)

\begin{tabular}{|l|l|c|}
\hline SRM & Description & $\begin{array}{c}\text { Unit of } \\
\text { Issue }\end{array}$ \\
\hline $\mathbf{8 9 8 3}$ & Silicon Nitride & $4.5 \mathrm{~g}$ \\
\hline
\end{tabular}

See Table 112.1 on the website for more information.

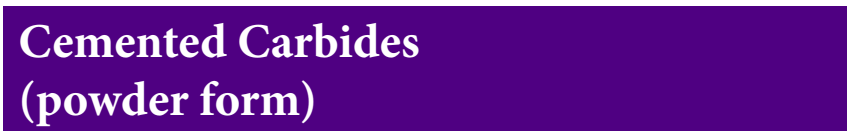

SRMs 887-889 are prepared from sintered tungsten carbide base materials.

\begin{tabular}{|l|l|c|}
\hline SRM & Description & $\begin{array}{c}\text { Unit of } \\
\text { Issue }\end{array}$ \\
\hline $\mathbf{8 8 7}$ & Cemented Carbide (W-83,Co-10) & $100 \mathrm{~g}$ \\
\hline $\mathbf{8 8 8}$ & Cemented Carbide (W-64,Co-25,Ta-5) & $100 \mathrm{~g}$ \\
\hline $\mathbf{8 8 9}$ & Cemented Carbide (W-75,Co-9,Ta-5,Ti-4) & $100 \mathrm{~g}$ \\
\hline
\end{tabular}

See Table 112.2 on the website for more information.

\section{Glasses (powder and solid forms)}

\begin{tabular}{|c|c|c|}
\hline SRM & Description & $\begin{array}{l}\text { Unit of } \\
\text { Issue }\end{array}$ \\
\hline 80a & Soda-Lime Glass & $45 \mathrm{~g}$ \\
\hline 81a & Glass Sand & $75 \mathrm{~g}$ \\
\hline 89 & Glass, Lead Barium & $45 \mathrm{~g}$ \\
\hline 92 & Soda-Lime Glass (Low Boron) & $45 \mathrm{~g}$ \\
\hline 93a & Borosilicate Glass & wafer \\
\hline $165 a$ & Glass Sand & $75 \mathrm{~g}$ \\
\hline 620 & Soda Lime, Flat & set (3) \\
\hline 1411 & Soft Borosilicate Glass & set (10) \\
\hline 1412 & Multicomponent Glass & set $(8)$ \\
\hline 1413 & High Alumina Sand & $75 \mathrm{~g}$ \\
\hline 1830 & $\begin{array}{l}\text { Soda Lime Float Glass (Nominal Mass } \\
\text { Fraction } 0.1 \% \mathrm{Al}_{2} \mathrm{O}_{3} \text { ) }\end{array}$ & 3 platelets \\
\hline 1831 & $\begin{array}{l}\text { Soda Lime Sheet Glass (Nominal Mass } \\
\text { Fraction } 1.2 \% \mathrm{Al}_{2} \mathrm{O}_{3} \text { ) }\end{array}$ & 3 platelets \\
\hline 2696 & Silica Fume & $70 \mathrm{~g}$ \\
\hline
\end{tabular}

See Table 112.3 on the website for more information.

\section{Trace Elements (wafer form)}

These SRMs are for calibrating instruments and evaluating analytical techniques used to determine trace elements in inorganic matrices. NOTE: The nominal glass composition of SRMs 610 through 617 is $72 \% \mathrm{SiO}_{2}, 12 \% \mathrm{CaO}$,

$14 \% \mathrm{Na}_{2} \mathrm{O}$, and $2 \% \mathrm{Al}_{2} \mathrm{O}_{3}$.

\begin{tabular}{|c|c|c|}
\hline SRM & Description & $\begin{array}{l}\text { Unit of } \\
\text { Issue }\end{array}$ \\
\hline 610 & Trace Elements in Glass & 4 wafers \\
\hline 611 & Trace Elements in Glass & 4 wafers \\
\hline 612 & Trace Elements in Glass & 4 wafers \\
\hline 613 & Trace Elements in Glass & 4 wafers \\
\hline 614 & Trace Elements in Glass & 4 wafers \\
\hline 616 & Trace Elements in Glass & 4 wafers \\
\hline 617 & Trace Elements in Glass & 4 wafers \\
\hline \multicolumn{3}{|c|}{$\begin{array}{l}\text { In addition to the elements listed above, the glass SRMs } \\
\text { contain the following } 23 \text { elements: Be, Bi, Cs, Cl, F, Ge, } \\
\mathrm{Hf}, \mathrm{Hg}, \mathrm{Li}, \mathrm{Lu}, \mathrm{Mg}, \mathrm{Nb}, \mathrm{P}, \mathrm{Pr}, \mathrm{S}, \mathrm{Tb}, \mathrm{Te}, \mathrm{Tm}, \mathrm{Sn}, \mathrm{W}, \mathrm{V}, \mathrm{Y} \text {, } \\
\text { and } \mathrm{Zr} \text {. }\end{array}$} \\
\hline
\end{tabular}

See Table 112.4 on the website for more information.

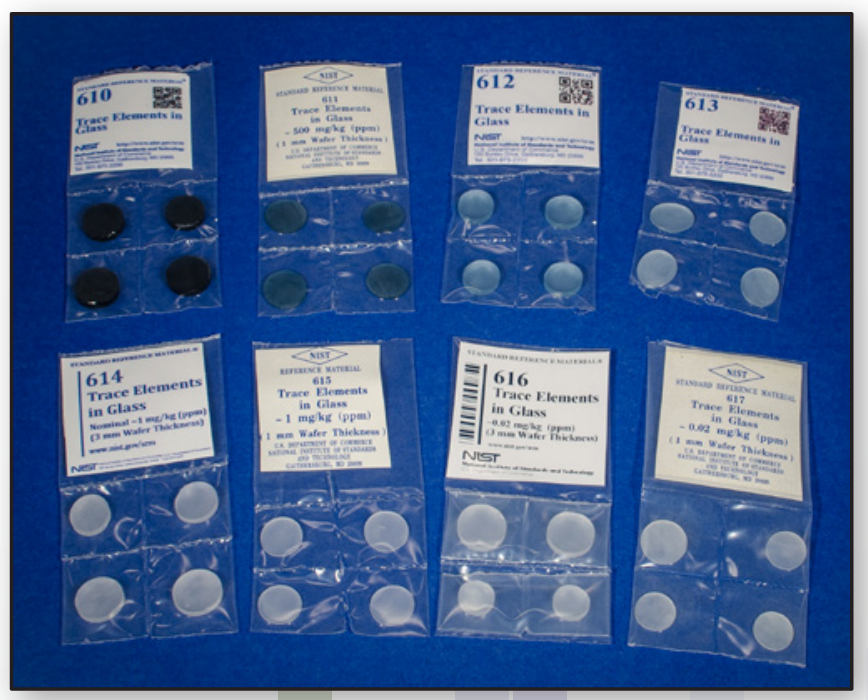





\section{Cements and Related Materials (powder form)}

These portland (1880b, 1881b, 1884b, 1885a, 1886a, 1887a, $1888 \mathrm{~b}$, and 1889a) and calcium aluminate (1882a and 1883a) cement SRMs are for $\mathrm{x}$-ray spectroscopic and chemical analysis of cements and related materials.

\begin{tabular}{|c|c|c|}
\hline SRM & Description & $\begin{array}{l}\text { Unit of } \\
\text { Issue }\end{array}$ \\
\hline 633a & Portland Cement & $4 \times 5 g$ \\
\hline 634a & Portland Cement & $100 \mathrm{~g}$ \\
\hline $635 a$ & Portland Cement (Blended with Slag) & $5 \times 5 g$ \\
\hline $1880 \mathrm{~b}$ & Portland Cement & $4 \times 5 \mathrm{~g}$ \\
\hline $1881 b$ & Portland Cement (Blended with Fly Ash) & $4 \times 5 g$ \\
\hline $1882 \mathrm{a}$ & Calcium Aluminate Cement & $4 \times 5 g$ \\
\hline $1883 a$ & Calcium Aluminate Cement & $4 \times 5 \mathrm{~g}$ \\
\hline $1884 \mathrm{~b}$ & Portland Cement & $5 \times 4.5 \mathrm{~g}$ \\
\hline $1885 b$ & Portland Cement & $5 \times 5 g$ \\
\hline $1886 a$ & $\begin{array}{l}\text { Portland Cement } \\
\text { (White Portland Cement with Low Iron) }\end{array}$ & $4 \times 5 \mathrm{~g}$ \\
\hline $1886 \mathrm{~b}$ & White Portland Cement & $5 \times 5 \mathrm{~g}$ \\
\hline $1887 \mathrm{~b}$ & Portland Cement & $5 \times 4 g$ \\
\hline $1888 b$ & Portland Cement & $4 \times 5 \mathrm{~g}$ \\
\hline $1889 a$ & $\begin{array}{l}\text { Portland Cement } \\
\text { (Blended with Limestone) }\end{array}$ & $4 \times 5 \mathrm{~g}$ \\
\hline 2429 & Flue Gas Desulfurization Gypsum & $200 \mathrm{~g}$ \\
\hline 2696 & Silica Fume & $70 \mathrm{~g}$ \\
\hline
\end{tabular}

See Table 113.1 on the website for more information.

\section{Portland Cement Clinkers (solid form)}

These SRMs provide certified values for the abundance of major phases in cement clinkers, i.e., the percentages of alite $\left(C_{3} S\right)$, belite $\left(C_{2} S\right)$, aluminate $\left(C_{3} A\right)$, and ferrite $\left(C_{2}(A, F)\right.$ ). NOTE: In cement chemist notation, $\mathrm{C}=\mathrm{CaO}, \mathrm{S}=\mathrm{SiO}_{2}$, $\mathrm{A}=\mathrm{Al}_{2} \mathrm{O}_{3}$ and $\mathrm{F}=\mathrm{Fe}_{2} \mathrm{O}_{3}$.

\begin{tabular}{|l|l|c|}
\hline SRM & Description & $\begin{array}{c}\text { Unit of } \\
\text { Issue }\end{array}$ \\
\hline $\mathbf{2 6 8 6 a}$ & Portland Cement Clinker & $4 \times 7 \mathrm{~g}$ \\
\hline $\mathbf{2 6 8 7}$ & Portland Cement Clinker & $3 \times 10 \mathrm{~g}$ \\
\hline $\mathbf{2 6 8 8}$ & Portland Cement Clinker & $3 \times 10 \mathrm{~g}$ \\
\hline
\end{tabular}

See Table 113.2 on the website for more information.

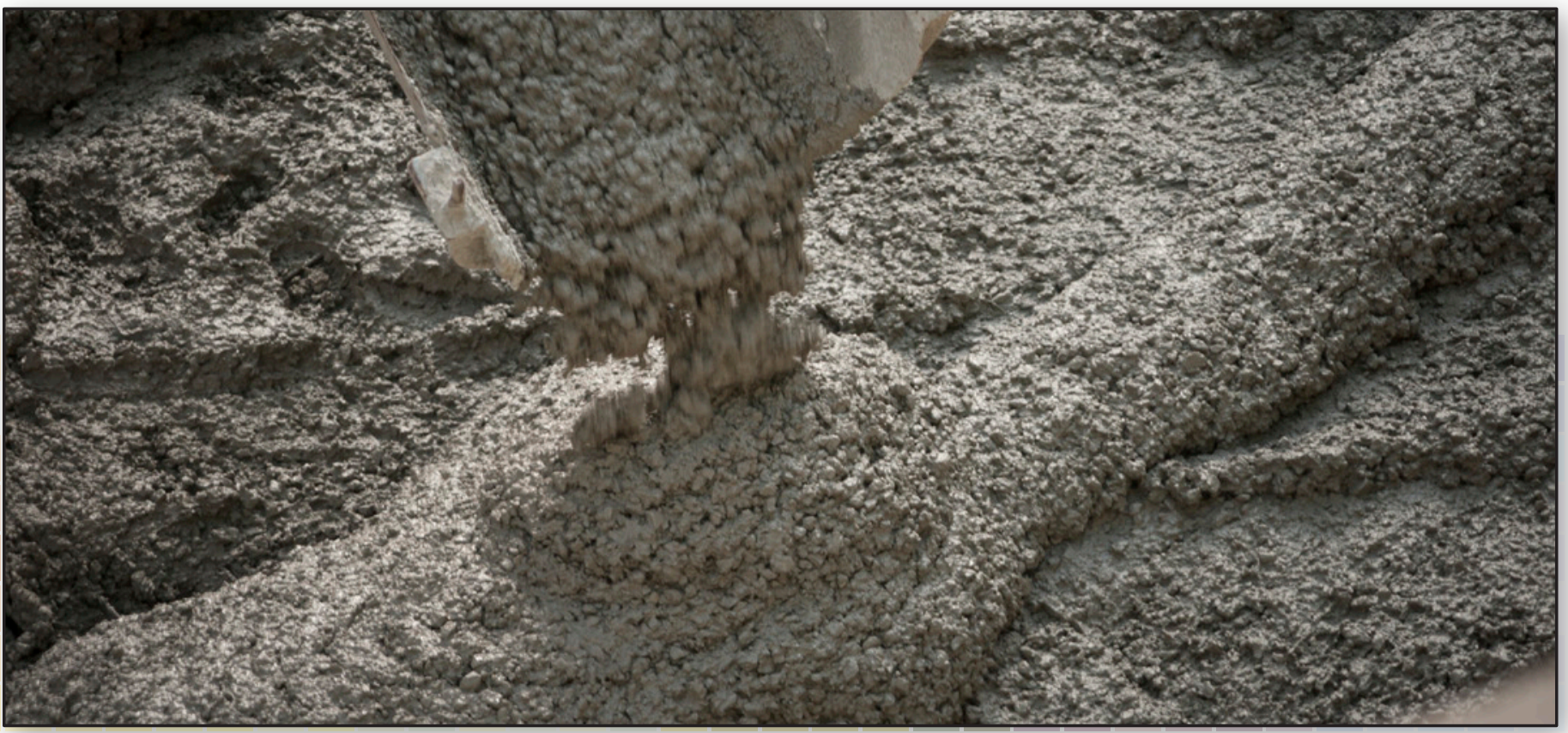


Lubricating Oils

\begin{tabular}{|l|l|c|}
\hline SRM & Description & $\begin{array}{c}\text { Unit of } \\
\text { Issue }\end{array}$ \\
\hline $\mathbf{1 0 8 3}$ & Wear Metals in Lubricating Oil & $150 \mathrm{~mL}$ \\
\hline $\mathbf{1 0 8 5}$ c & Wear Metals in Lubricating Oil & set (10) \\
\hline $\mathbf{1 8 1 8 a}$ & Chlorine in Lubricating Base Oils & set $(5)$ \\
\hline $\mathbf{1 8 1 9 a}$ & Sulfur in Lubricating Base Oil & set $(5)$ \\
\hline $\mathbf{1 8 4 8}$ & Lubricating Oil Additive Package & $100 \mathrm{~g}$ \\
\hline
\end{tabular}

See Table 114.2 on the website for more information.

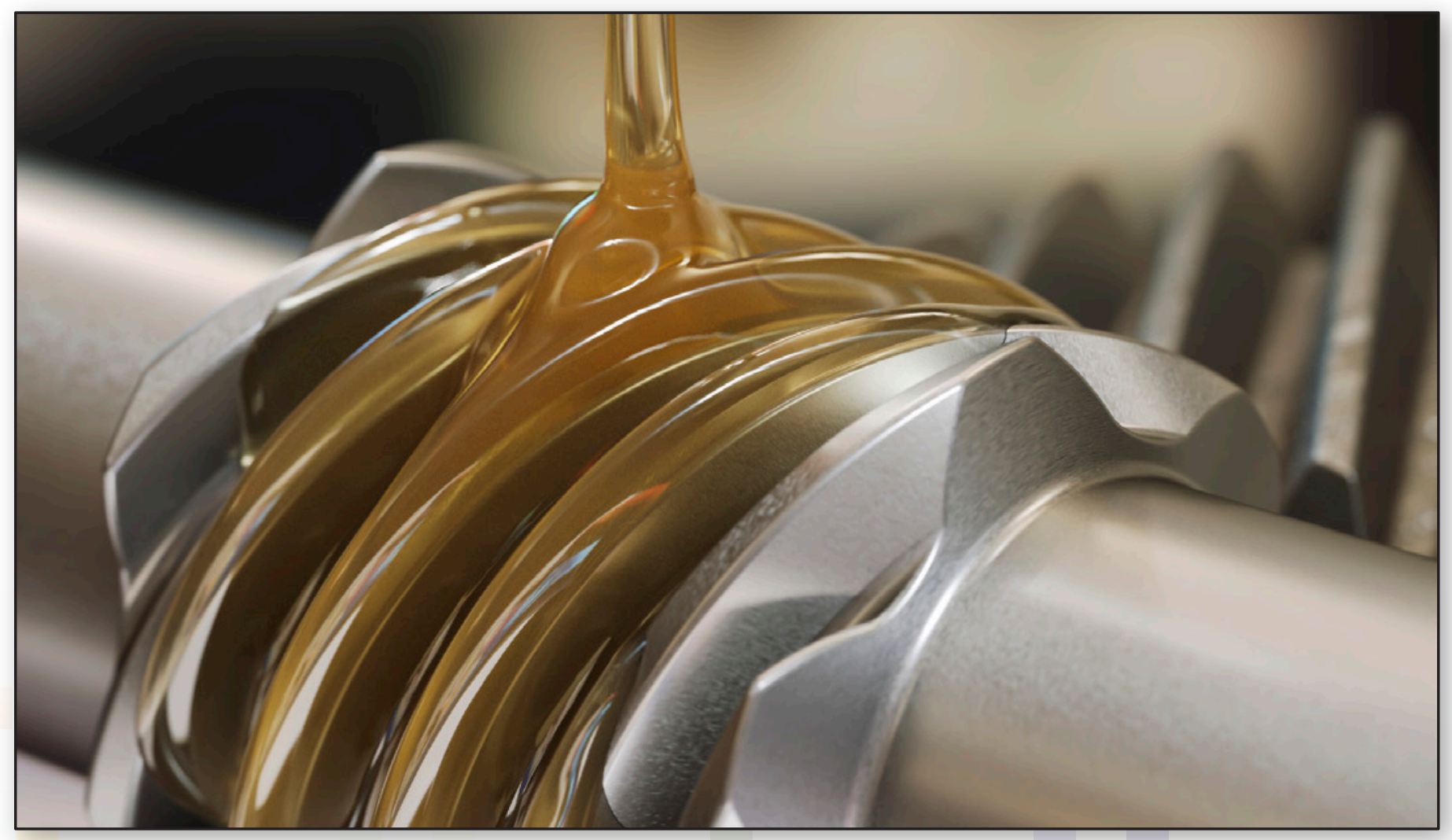



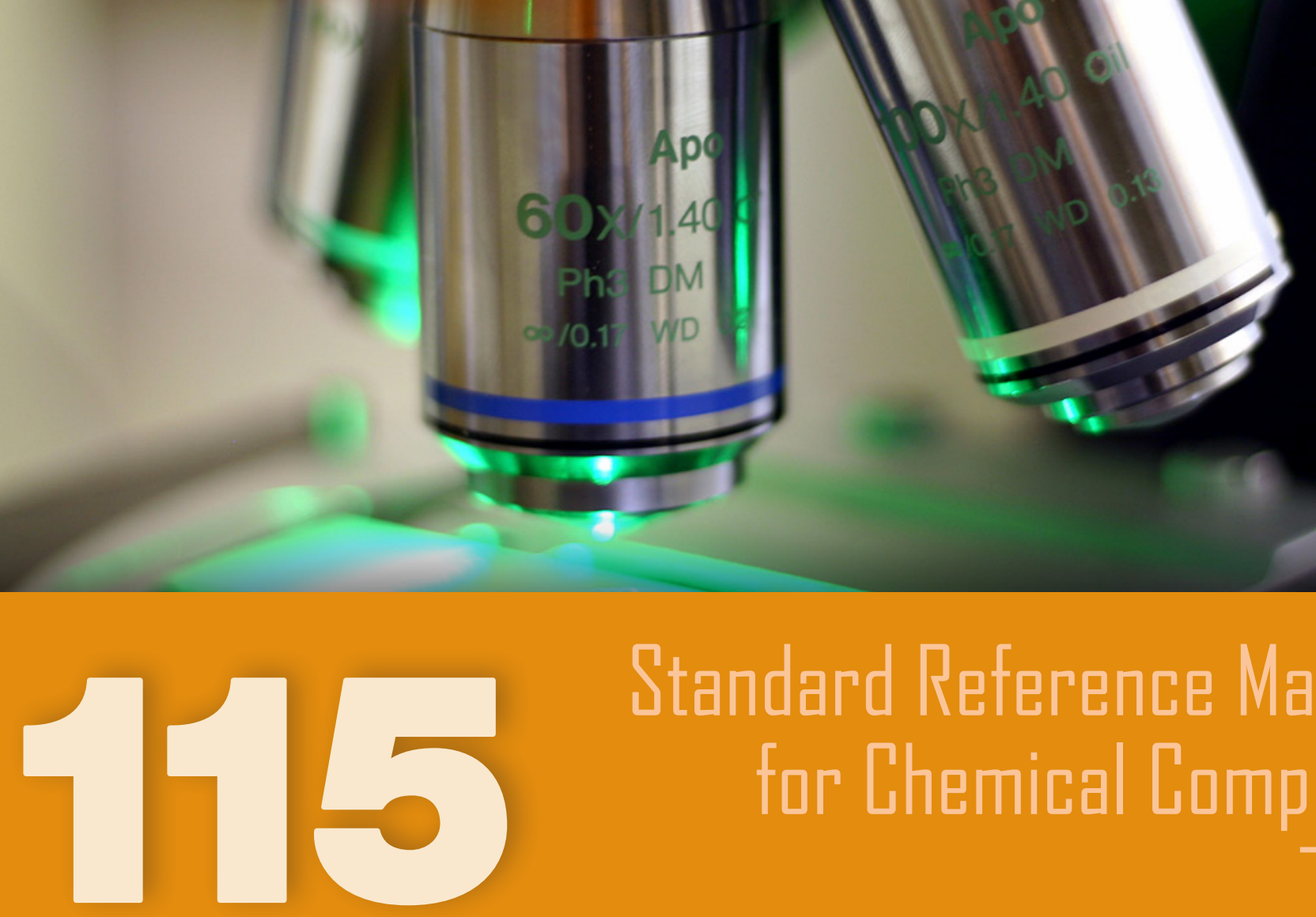

Standard Reference Materials far Chemical Campasitian Forensics

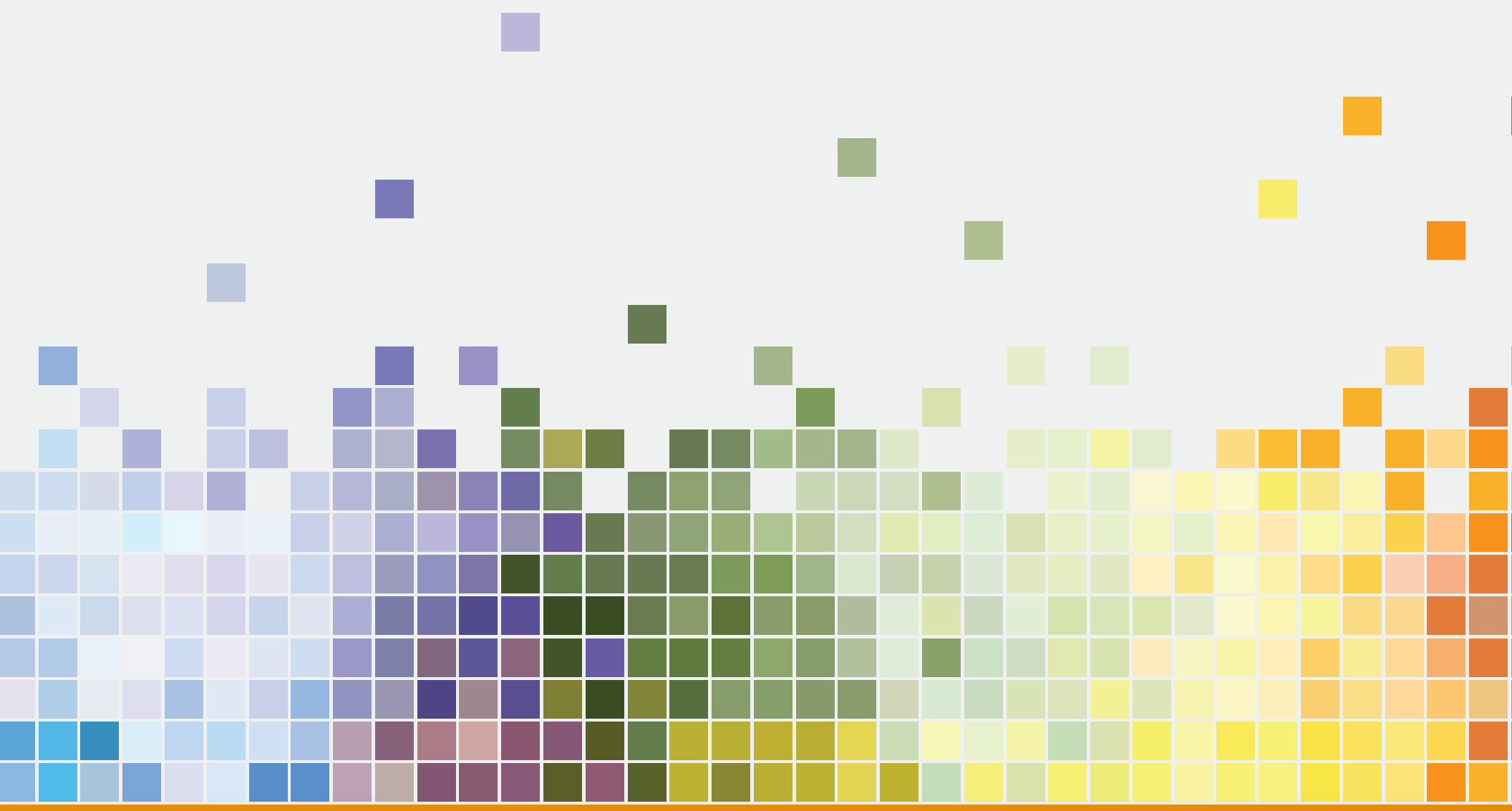

www.nist.gov/srm | Phone: 301.975.2200 | Fax: 301.948.3730 | Email: srminfo@nist.gov 


\section{Ethanol Solutions}

\begin{tabular}{|c|c|c|}
\hline SRM & Description & $\begin{array}{l}\text { Unit of } \\
\text { Issue }\end{array}$ \\
\hline $1828 b$ & Ethanol-Water Solutions & $6 \times 1.2 \mathrm{~mL}$ \\
\hline 2891 & $\begin{array}{l}\text { Ethanol-Water Solution } \\
\text { (Nominal Mass Fraction } 0.02 \% \text { ) }\end{array}$ & $5 \times 1.2 \mathrm{~mL}$ \\
\hline 2892 & $\begin{array}{l}\text { Ethanol-Water Solution } \\
\text { (Nominal Mass Fraction } 0.04 \% \text { ) }\end{array}$ & $5 \times 1.2 \mathrm{~mL}$ \\
\hline 2893 & $\begin{array}{l}\text { Ethanol-Water Solution } \\
\text { (Nominal Mass Fraction } 0.08 \% \text { ) }\end{array}$ & $5 \times 1.2 \mathrm{~mL}$ \\
\hline 2894 & $\begin{array}{l}\text { Ethanol-Water Solution } \\
\text { (Nominal Mass Fraction } 0.1 \% \text { ) }\end{array}$ & $5 \times 1.2 \mathrm{~mL}$ \\
\hline 2895 & $\begin{array}{l}\text { Ethanol-Water Solution } \\
\text { (Nominal Mass Fraction } 0.2 \% \text { ) }\end{array}$ & $5 \times 1.2 \mathrm{~mL}$ \\
\hline 2896 & $\begin{array}{l}\text { Ethanol-Water Solution } \\
\text { (Nominal Mass Fraction } 0.3 \% \text { ) }\end{array}$ & $5 \times 1.2 \mathrm{~mL}$ \\
\hline $2897 a$ & $\begin{array}{l}\text { Ethanol Water Solution } \\
\text { (Nominal Mass Fraction } 2 \% \text { ) }\end{array}$ & $5 \times 10 \mathrm{~mL}$ \\
\hline 2898a & $\begin{array}{l}\text { Ethanol Water Solution } \\
\text { (Nominal Mass Fraction } 6 \% \text { ) }\end{array}$ & $5 \times 10 \mathrm{~mL}$ \\
\hline $2899 a$ & $\begin{array}{l}\text { Ethanol-Water Solution } \\
\text { (Nominal Mass Fraction } 25 \% \text { ) }\end{array}$ & $5 \times 10 \mathrm{~mL}$ \\
\hline 2900 & $\begin{array}{l}\text { Ethanol-Water Solution } \\
\text { (Nominal Mass Fraction } 95.6 \% \text { ) }\end{array}$ & $5 \times 10 \mathrm{~mL}$ \\
\hline
\end{tabular}

See Table 105.3 on the website for more information.

\section{Drugs of Abuse}

\section{(hair, serum, and urine)}

\begin{tabular}{|l|l|c|}
\hline SRM & Description & $\begin{array}{c}\text { Unit of } \\
\text { Issue }\end{array}$ \\
\hline 1507b & THC-COOH in Freeze-Dried Urine & set (3) \\
\hline 1508a & $\begin{array}{l}\text { Benzoylecgonine (Cocaine Metabolite) } \\
\text { in Freeze-dried Urine }\end{array}$ & set (4) \\
\hline
\end{tabular}

See Table 105.7 on the website for more information.

\section{DNA Profiling and Nucleic Acid Materials (solid forms)}

\begin{tabular}{|l|l|c|}
\hline SRM & Description & $\begin{array}{c}\text { Unit of } \\
\text { Issue }\end{array}$ \\
\hline $\mathbf{2 3 6 6 a}$ & $\begin{array}{l}\text { Cytomegalovirus DNA (Towne } \\
\text { for DNA Measurements }\end{array}$ & 1 vial \\
\hline $\mathbf{2 3 7 2}$ & Human DNA Quantitation Standard & set (3) \\
\hline 2373 & $\begin{array}{l}\text { Genomic DNA Standards for } \\
\text { HER2 Measurements }\end{array}$ & 5 vials \\
\hline $\mathbf{2 3 7 4}$ & $\begin{array}{l}\text { DNA Sequence Library for External } \\
\text { RNA Controls }\end{array}$ & 96 tubes \\
\hline
\end{tabular}

\begin{tabular}{|c|c|c|}
\hline SRM & Description & $\begin{array}{c}\text { Unit of } \\
\text { Issue }\end{array}$ \\
\hline 2391c & PCR-Based DNA Profiling Standard & 6 vials \\
\hline 2392 & Mitochondrial DNA Sequencing & set (3) \\
\hline 2392-I & $\begin{array}{l}\text { Mitochondrial DNA Sequencing } \\
\text { (Human HL-60 DNA) }\end{array}$ & 1 vial \\
\hline 2393 & $\begin{array}{l}\text { CAG Repeat Length Mutation } \\
\text { in Huntington's Disease }\end{array}$ & set $(6)$ \\
\hline 2394 & $\begin{array}{l}\text { Heteroplasmic Mitochondrial DNA } \\
\text { Mutation Detection Std }\end{array}$ & set $(10)$ \\
\hline 2396 & $\begin{array}{l}\text { Oxidative DNA Damage Mass } \\
\text { Spectrometry Standards }\end{array}$ & set $(10)$ \\
\hline 8375 & $\begin{array}{l}\text { Microbial Genomic DNA Standards } \\
\text { for Sequencing Performance Assessment }\end{array}$ & 4 vials \\
\hline 8391 & $\begin{array}{l}\text { Human DNA for Whole-Variant Assessment } \\
\text { (Son of Eastern European Ashkenazim } \\
\text { Jewish Ancestry) }\end{array}$ & 1 vial \\
\hline 8392 & $\begin{array}{l}\text { Human DNA for Whole-Genome } \\
\text { Variant Assessment (Trio of Eastern } \\
\text { European Ashkenazim Jewish Ancestry) }\end{array}$ & 3 vials \\
\hline 8393 & $\begin{array}{l}\text { Human DNA for Whole-Genome Variant } \\
\text { Assessment (Son of Chinese Ancestry) }\end{array}$ & 1 vial \\
\hline 8398 & $\begin{array}{l}\text { Human DNA for Whole-Genome Variant } \\
\text { Assessment (Daughter of Utah/European } \\
\text { Ancestry) }\end{array}$ & 1 vial \\
\hline
\end{tabular}

See Table 105.8 on the website for more information.

\section{Crime Scene Investigations}

\begin{tabular}{|l|l|c|}
\hline SRM & Description & $\begin{array}{c}\text { Unit of } \\
\text { Issue }\end{array}$ \\
\hline $\mathbf{2 2 8 5}$ & Ignitable Liquids Test Mixture & $5 \times 1.2 \mathrm{~mL}$ \\
\hline $\mathbf{2 4 6 0}$ & Standard Bullet & each \\
\hline $\mathbf{2 4 6 1}$ & Standard Cartridge Case & each \\
\hline $\mathbf{2 9 0 5}$ & Trace Terrorist Explosives Simulants & $4 \times 1 \mathrm{~g}$ \\
\hline $\mathbf{2 9 0 7}$ & Trace Terrorist Explosives Simulants & 2 bottles \\
\hline
\end{tabular}

See Table 109.4 on the website for more information.

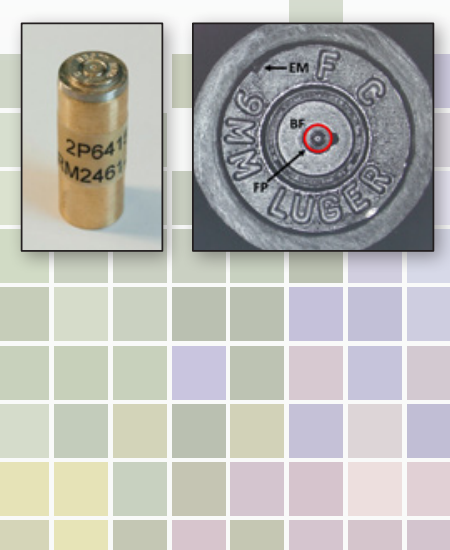

Right - optical micrograph showing the three certified areas of the SRM, breech face impression (BF), firing pin impression (FP), and ejector mark (EM);

Left - a NIST SRM 2461 Standard Cartridge Case mounted on a brass cylinder holder. 


\section{arising}
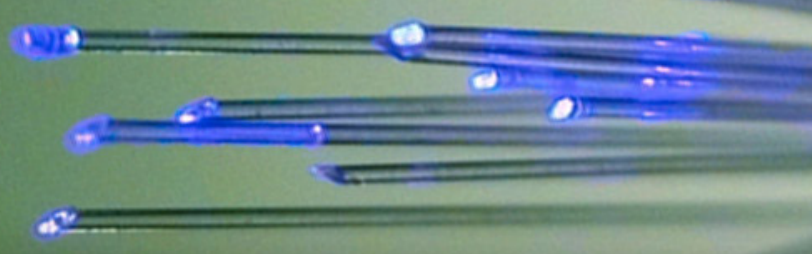

\section{Standard Reference Materials}

far Physical Properties Ion Activity
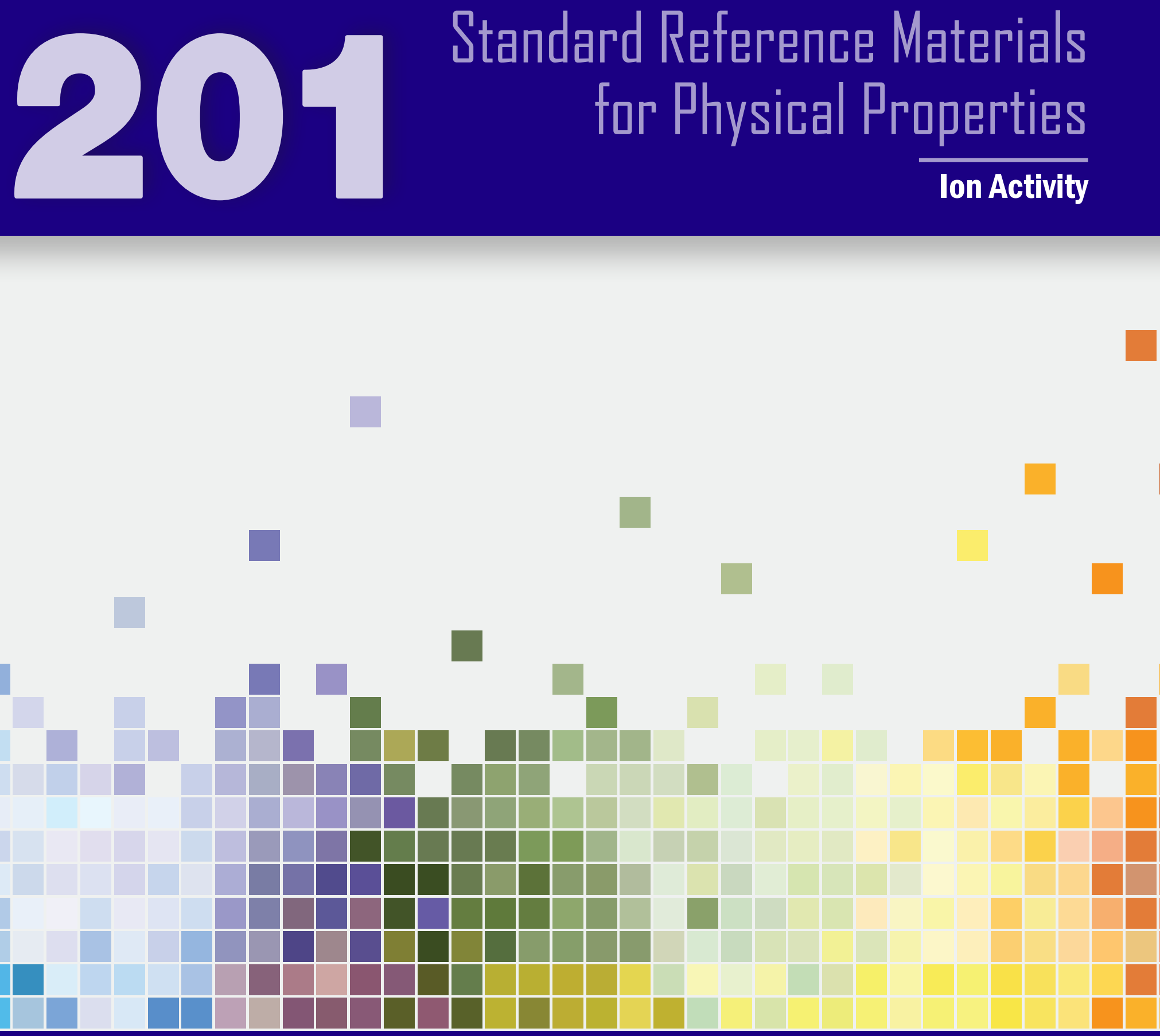

www.nist.gov/srm | Phone: 301.975.2200 | Fax: 301.948.3730 | Email: srminfo@nist.gov 57 


\section{pH Calibration (powder form)}

These SRMs are used to prepare solutions of known hydrogen ion activity to calibrate commercial $\mathrm{pH}$ instruments. SRMs 186g and 191d are each certified for use as an admixture only. SRM 186g (186-I-g and 186-II-g) may be used to prepare solutions with a $\mathrm{pH}$ of 6.8640 at $25^{\circ} \mathrm{C}$, or physiological buffer solutions with a $\mathrm{pH}$ of 7.4157 at $25^{\circ} \mathrm{C}$.

\begin{tabular}{|l|l|c|}
\hline SRM & Description & $\begin{array}{c}\text { Unit of } \\
\text { Issue }\end{array}$ \\
\hline $\mathbf{1 8 5 i}$ & $\begin{array}{l}\text { Potassium Hydrogen Phthalate } \\
\text { pH Standard }\end{array}$ & $60 \mathrm{~g}$ \\
\hline $\mathbf{1 8 6 g}$ & $\begin{array}{l}\text { pH Standards Potassium Dihydrogen } \\
\text { Phosphate (186-I-g) } \\
\text { Disodium Hydrogen Phosphate (186-II-g) }\end{array}$ & $\begin{array}{c}1 \times 30 \mathrm{~g} ; \\
1 \times 45 \mathrm{~g}\end{array}$ \\
\hline $\mathbf{1 8 7 e}$ & Sodium Tetraborate (Borax), pH & $30 \mathrm{~g}$ \\
\hline $\mathbf{1 8 8}$ & $\begin{array}{l}\text { Potassium Hydrogen Tartrate } \\
\text { (pH Standard) }\end{array}$ & $\begin{array}{l}\text { Potassium Tetroxalate Dihydrate } \\
\text { pH Standard }\end{array}$ \\
\hline $\mathbf{1 9 1 d}$ & $\begin{array}{l}\text { pH Standard } \\
\text { Sodium Bicarbonate (191d-I) } \\
\text { Sodium Carbonate (191d-II) }\end{array}$ & $\begin{array}{l}65 \mathrm{~g} \\
1 \times 30 \mathrm{~g}\end{array}$ \\
\hline 2193a & $\begin{array}{l}\text { Calcium Carbonate } \mathrm{pH} \text { Standard } \\
\text { [used as saturated Ca(OH) }{ }_{2} \text { solution] }\end{array}$ & $30 \mathrm{~g}$ \\
\hline
\end{tabular}

See Table 201.1 on the website for more information.

\section{Biological Buffer Systems (powder form)}

These SRMs are used to calibrate clinical instruments (e.g., blood $\mathrm{pH}$ measurements), in the range of $\mathrm{pH} 7$ to 8 . They are each certified for use as an admixture only. The $\mathrm{pH}(\mathrm{S})$ values for the buffer solutions are certified at 0.05 molal and 0.08 molal with respect to the free acid and the sodium salt admixture as a function of temperature.

\begin{tabular}{|l|l|c|}
\hline SRM & Description & $\begin{array}{c}\text { Unit of } \\
\text { Issue }\end{array}$ \\
\hline $\mathbf{2 1 8 1}$ & HEPES & $60 \mathrm{~g}$ \\
\hline $\mathbf{2 1 8 2}$ & HEPES Sodium Salt & $60 \mathrm{~g}$ \\
\hline
\end{tabular}

See Table 201.2 on the website for more information.

\section{pD Calibration (powder form)}

These SRMs are for the preparation of solutions of known deuterium ion activity to calibrate $\mathrm{pH}$ instruments to indicate pD data. SRMs 2186-I and 2186-II, and 2191a and 2192a are certified for use as admixtures only.

\begin{tabular}{|l|l|c|}
\hline SRM & Description & $\begin{array}{c}\text { Unit of } \\
\text { Issue }\end{array}$ \\
\hline 2185 & Potassium Hydrogen Phthalate pD Standard & $60 \mathrm{~g}$ \\
\hline 2186I & Potassium Dihydrogen Phosphate & $30 \mathrm{~g}$ \\
\hline 2186II & Disodium Hydrogen Phosphate & $30 \mathrm{~g}$ \\
\hline 2191a & Sodium Bicarbonate & $30 \mathrm{~g}$ \\
\hline 2192a & Sodium Carbonate & $30 \mathrm{~g}$ \\
\hline
\end{tabular}

See Table 201.3 on the website for more information.

\section{Ion-Selective Electrode Calibration (powder form)}

These SRMs are certified for the calibration of ion-selective electrodes and have conventional ionic activities based on the Stokes-Robinson hydration theory for ionic strengths greater than $0.1 \mathrm{~mol} / \mathrm{L}$.

\begin{tabular}{|l|l|c|}
\hline SRM & Description & $\begin{array}{c}\text { Unit of } \\
\text { Issue }\end{array}$ \\
\hline $\mathbf{2 2 0 1}$ & Sodium Chloride (Ion-Selective) & $125 \mathrm{~g}$ \\
\hline $\mathbf{2 2 0 3}$ & $\begin{array}{l}\text { Potassium Fluoride (Standard for } \\
\text { Ion-Selective Electrodes) }\end{array}$ & $125 \mathrm{~g}$ \\
\hline
\end{tabular}

See Table 201.4 on the website for more information.

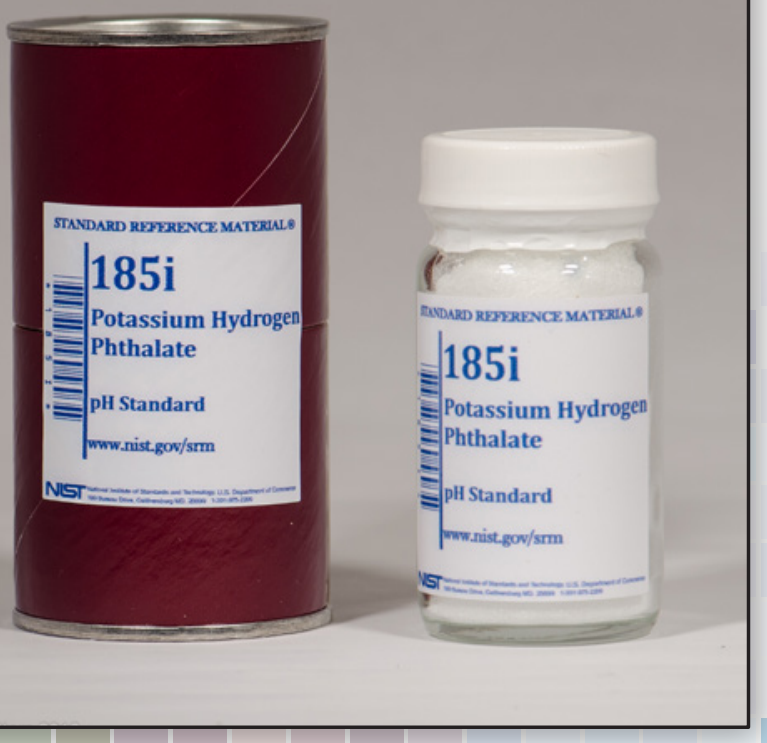




\section{2}
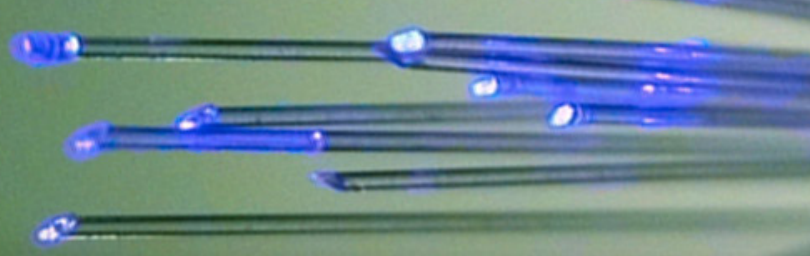

\section{Standard Reference Materials}

for Physical Properties $\frac{\text { fрг Physical Ргрperties }}{\text { Polymeric Properties }}$

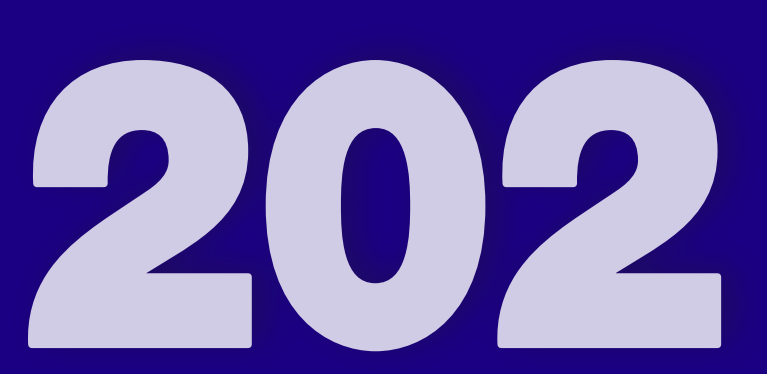




\section{Polymers \\ (liquid, pellet, and powder forms)}

These SRMs are for the calibration of instrumentation used in polymer technology science for the determination of molecular weight and molecular weight distribution and as characterized samples for other physical properties of polymers.

\section{Polymers}

\begin{tabular}{|c|c|c|}
\hline SRM & Description & $\begin{array}{l}\text { Unit of } \\
\text { Issue }\end{array}$ \\
\hline $705 a$ & $\begin{array}{l}\text { Polystyrene } \\
\text { (Narrow Molecular Weight Distribution) }\end{array}$ & $5 \mathrm{~g}$ \\
\hline $706 a$ & $\begin{array}{l}\text { Polystyrene (Broad Molecular Mass } \\
\text { Distribution) }\end{array}$ & $18 \mathrm{~g}$ \\
\hline $1473 c$ & Low Density Polyethylene Resin & $60 \mathrm{~g}$ \\
\hline $1474 b$ & Polyethylene Resin & $60 \mathrm{~g}$ \\
\hline $1475 a$ & Polyethylene, Linear & $50 \mathrm{~g}$ \\
\hline $1476 a$ & Branched Polyethylene Resin & $12 \mathrm{~g}$ \\
\hline 1478 & $\begin{array}{l}\text { Polystyrene } \\
\text { (Narrow Molecular Weight Distribution) }\end{array}$ & $2 \mathrm{~g}$ \\
\hline 1479 & $\begin{array}{l}\text { Polystyrene } \\
\text { (Narrow Molecular Weight Distribution) }\end{array}$ & $2 \mathrm{~g}$ \\
\hline $1482 a$ & Polyethylene & $0.3 \mathrm{~g}$ \\
\hline $1483 a$ & Linear Polyethylene & $0.3 \mathrm{~g}$ \\
\hline $1484 a$ & Linear Polyethylene & $0.3 \mathrm{~g}$ \\
\hline 1487 & $\begin{array}{l}\text { Poly(Methyl Methacrylate) } \\
\text { (6 K Narrow Molecular Weight Distribution) }\end{array}$ & $2 \mathrm{~g}$ \\
\hline 1488 & $\begin{array}{l}\text { Poly(Methyl Methacrylate) } \\
\text { (29 K Narrow Molecular Weight Distribution) }\end{array}$ & $2 \mathrm{~g}$ \\
\hline 2881 & $\begin{array}{l}\text { Polystyrene Absolute Molecular Mass } \\
\text { Distribution Standard }\end{array}$ & $0.3 \mathrm{~g}$ \\
\hline 2885 & Polyethylene $\left(\mathrm{M}_{\mathrm{W}}, 6280 \mathrm{~g} / \mathrm{mol}\right)$ & $0.3 \mathrm{~g}$ \\
\hline 2886 & Polyethylene $\left(\mathrm{M}_{\mathrm{W}}, 87000 \mathrm{~g} / \mathrm{mol}\right)$ & $0.3 \mathrm{~g}$ \\
\hline 2887 & Polyethylene $\left(\mathrm{M}_{\mathrm{W}}, 196400 \mathrm{~g} / \mathrm{mol}\right)$ & $0.3 \mathrm{~g}$ \\
\hline
\end{tabular}

See Table 202.1 on the website for more information.

\section{Melt Flow Rate}

\begin{tabular}{|l|l|c|}
\hline SRM & Description & $\begin{array}{c}\text { Unit of } \\
\text { Issue }\end{array}$ \\
\hline $\mathbf{1 4 9 6}$ & Unpigmented Polyethylene Gas Pipe Resin & $0.9 \mathrm{~kg}$ \\
\hline
\end{tabular}

See Table 202.1 on the website for more information.

\section{Viscosity}

\begin{tabular}{|l|l|c|}
\hline SRM & Description & $\begin{array}{c}\text { Unit of } \\
\text { Issue }\end{array}$ \\
\hline $\mathbf{2 4 9 0}$ & $\begin{array}{l}\text { Non-Newtonian Polymer Solution } \\
\text { for Rheological Measurements }\end{array}$ & $100 \mathrm{~mL}$ \\
\hline 2492 & $\begin{array}{l}\text { Bingham Paste Mixture } \\
\text { for Rheological Measurements }\end{array}$ & $\begin{array}{c}\text { kit for } \\
\text { two } \\
\text { batches }\end{array}$ \\
\hline $\mathbf{2 4 9 3}$ & $\begin{array}{l}\text { Bingham Mortar Mixture } \\
\text { for Rheological Measurements }\end{array}$ & $\begin{array}{c}\text { kit for } \\
\text { two } \\
\text { batches }\end{array}$ \\
\hline
\end{tabular}

See Table 202.1 on the website for more information.

\section{Biomaterials}

\begin{tabular}{|l|l|c|}
\hline SRM & Description & $\begin{array}{c}\text { Unit of } \\
\text { Issue }\end{array}$ \\
\hline $\mathbf{8 3 9 4}$ & $\begin{array}{l}\text { Tissue Engineering Reference Scaffolds } \\
\text { for Cell Culture }\end{array}$ & $\begin{array}{c}24 \\
\text { scaffolds }\end{array}$ \\
\hline
\end{tabular}

See Table 202.1 on the website for more information.
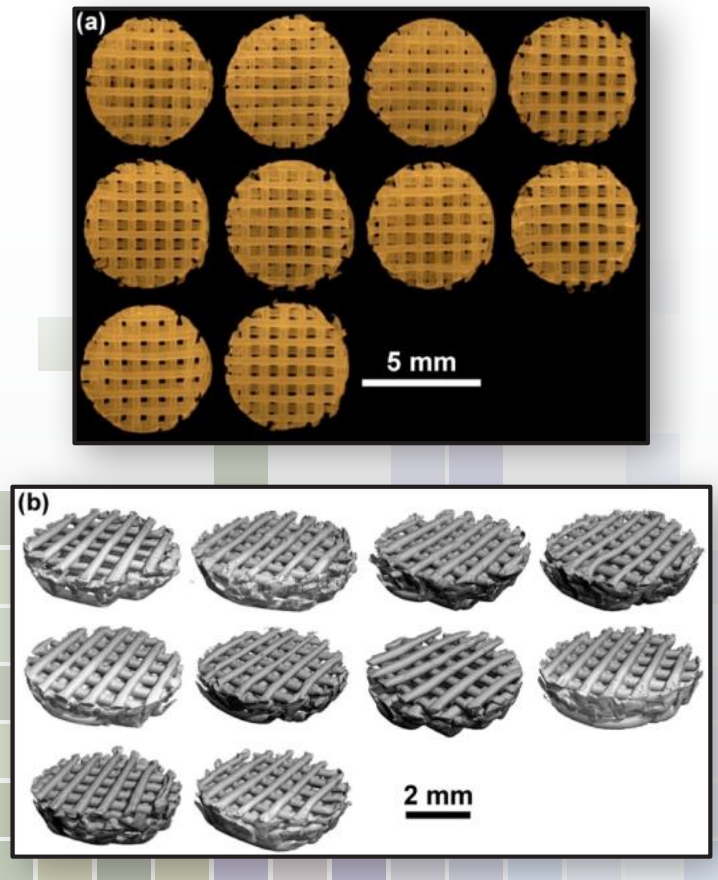

RM 8394: 10 scaffolds used for structural characterization as

(a) Stereomicrographs and (b) X ray microcomputed 3D tomographs. 


\section{$2+x^{2}$}
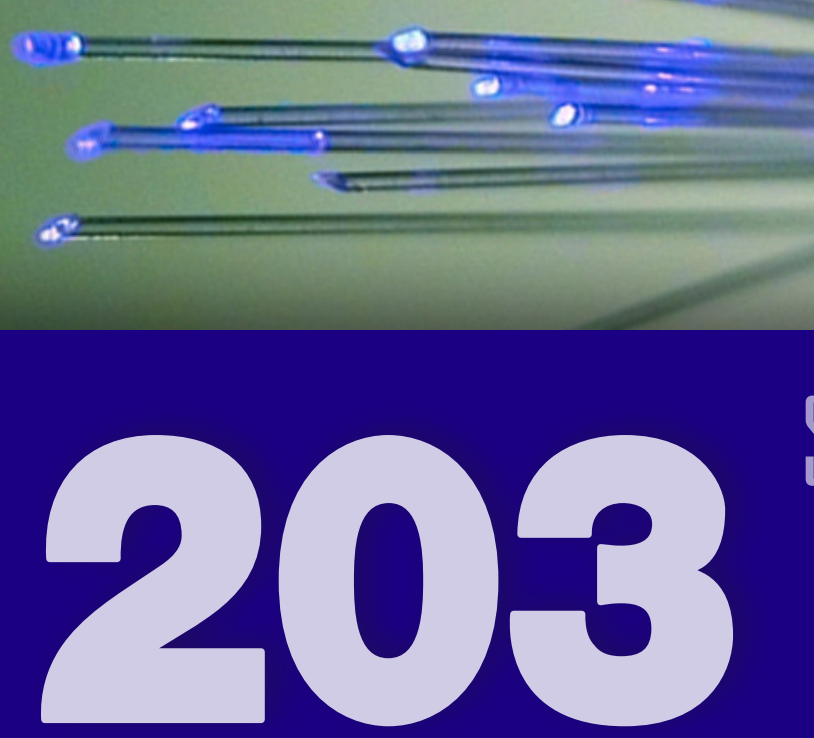

\section{Standard Reference Materials}

far Physical Properties

\section{Thermodynamic Properties}

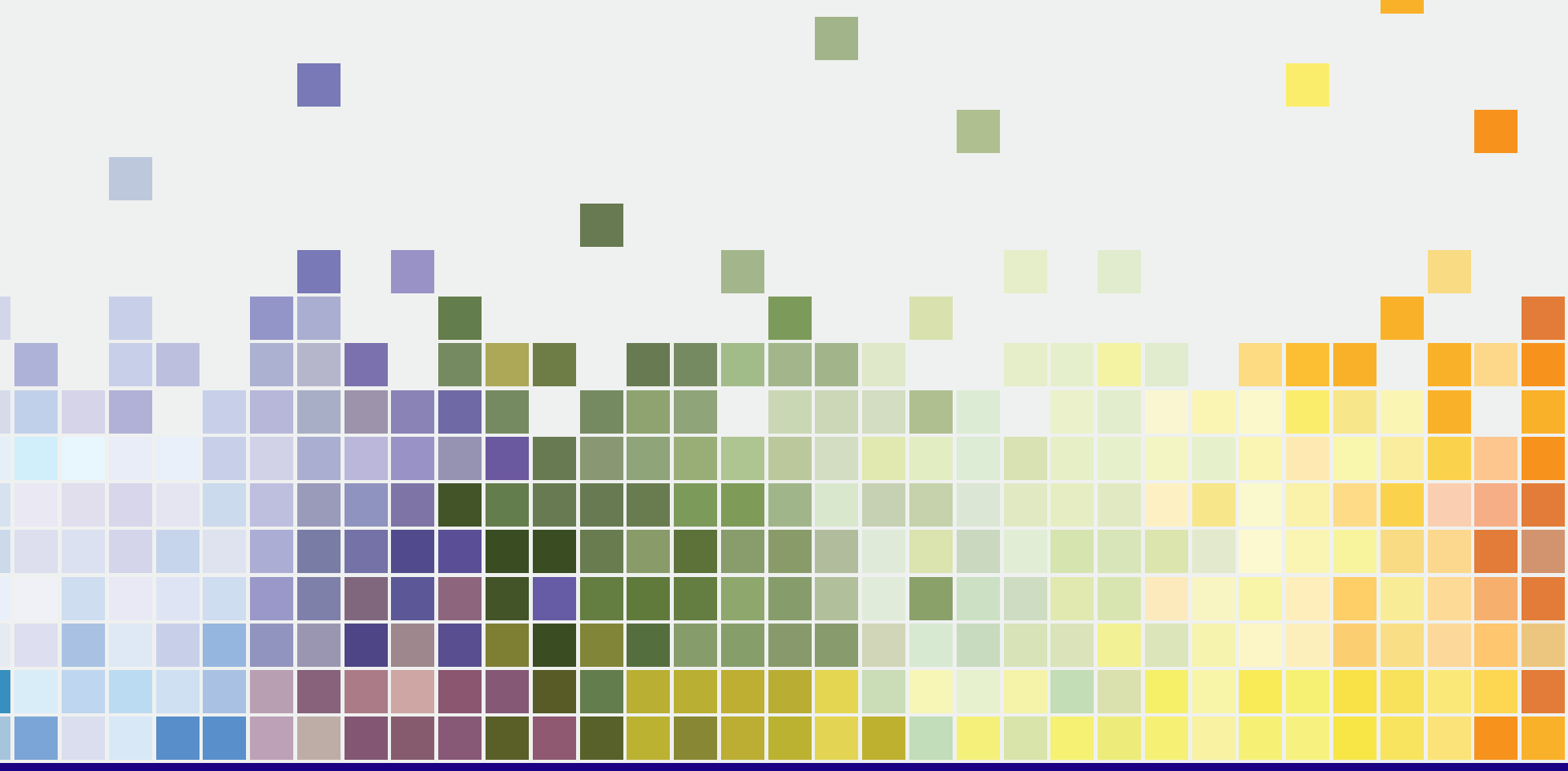

www.nist.gov/srm | Phone: 301.975.2200 | Fax: 301.948.3730 | Email: srminfo@nist.gov 


\section{Combustion Calorimetry}

(powder form)

These SRMs are for use as standards for calibration of combustion bomb calorimeters used in checking the performance of apparatus and analytical procedures.

\begin{tabular}{|l|l|c|}
\hline SRM & Description & $\begin{array}{c}\text { Unit of } \\
\text { Issue }\end{array}$ \\
\hline $\mathbf{3 9 j}$ & Benzoic Acid (Calorimetric Standard) & $30 \mathrm{~g}$ \\
\hline $\mathbf{1 6 5 6}$ & $\begin{array}{l}\text { Thianthrene Combustion Calorimetric } \\
\text { Standard }\end{array}$ & $30 \mathrm{~g}$ \\
\hline $\mathbf{1 6 5 7}$ & $\begin{array}{l}\text { Synthetic Refuse-Derived Fuel } \\
\text { Combustion Calorimetric Standard }\end{array}$ & $100 \mathrm{~g}$ \\
\hline $\mathbf{2 1 5 2}$ & Urea Combustion Calorimetric Standard & $25 \mathrm{~g}$ \\
\hline
\end{tabular}

See Table 203.1 on the website for more information.

\section{Solution Calorimetry}

This SRM is for calibration and validation of differential scanning calorimeters, differential thermal analyzers, and similar instruments.

\begin{tabular}{|l|l|c|}
\hline SRM & Description & $\begin{array}{c}\text { Unit of } \\
\text { Issue }\end{array}$ \\
\hline $\mathbf{1 6 5 5}$ & $\begin{array}{l}\text { Potassium Chloride, } \mathrm{KCl}(\mathrm{cr}) \\
\text { for Solution Calorimetry }\end{array}$ & $30 \mathrm{~g}$ \\
\hline
\end{tabular}

See Table 203.2 on the website for more information.

\section{Enthalpy and Temperature of Fusion}

These SRMs are for calibration and validation of differential scanning calorimeters, differential thermal analyzers, and similar instruments.

\begin{tabular}{|l|l|c|}
\hline SRM & Description & $\begin{array}{c}\text { Unit of } \\
\text { Issue }\end{array}$ \\
\hline $\mathbf{2 2 3 4}$ & Gallium for Thermal Analysis & $2 \mathrm{~g}$ \\
\hline $\mathbf{2 2 3 5}$ & Bismuth for Thermal Analysis & $1.5 \mathrm{~g}$ \\
\hline
\end{tabular}

See Table 203.5 on the website for more information.

\section{Differential Scanning Calorimetry and Differential Thermal Analysis}

These SRMs are for calibration and validation of differential scanning calorimeters, differential thermal analyzers, and similar instruments.

\section{Enthalpy and Heat Capacity}

\begin{tabular}{|l|l|c|}
\hline SRM & Description & $\begin{array}{c}\text { Unit of } \\
\text { Issue }\end{array}$ \\
\hline 705a & $\begin{array}{l}\text { Polystyrene (Narrow Molecular } \\
\text { Weight Distribution) }\end{array}$ & $5 \mathrm{~g}$ \\
\hline 720 & Sapphire Heat Capacity & $15 \mathrm{~g}$ \\
\hline 781D2 & Molybdenum - Heat Capacity & $10 \mathrm{~cm}$ \\
\hline
\end{tabular}

See Table 203.5 on the website for more information.

\section{Thermal Analysis Purity Set}

SRM 1514 is for evaluating methods of determining purity by differential scanning calorimetry. It consists of pure phenacetin and phenacetin doped with p-aminobenzoic acid.

\begin{tabular}{|l|l|c|}
\hline SRM & Description & $\begin{array}{c}\text { Unit of } \\
\text { Issue }\end{array}$ \\
\hline $\mathbf{1 5 1 4}$ & Thermal Analysis Purity Set & set (4) \\
\hline
\end{tabular}

See Table 203.5 on the website for more information.

\section{Defining Fixed Point, International Temperature Scale of 1990, ITS-90 (solid forms)}

These SRMs are for use in preparing defining fixed points of the International Temperature Scale of 1990, ITS-90.

\begin{tabular}{l|l|c|}
\hline SRM & Description & $\begin{array}{c}\text { Unit of } \\
\text { Issue }\end{array}$ \\
\hline 740a & Zinc Freezing Point Standard & $200 \mathrm{~g}$ \\
\hline 741a & Tin Freezing-Point Standard & $200 \mathrm{~g}$ \\
\hline $\mathbf{1 7 4 6}$ & Silver Freezing-Point Standard & $300 \mathrm{~g}$ \\
\hline $\mathbf{1 7 5 1}$ & Gallium Melting-Point Standard & $200 \mathrm{~g}$ \\
\hline
\end{tabular}




\section{Reference Points (solid forms)}

These moderate purity SRMs are for use in preparing reference point devices and for calibrating thermometers, thermocouples and other temperature measuring devices.

\begin{tabular}{|l|l|c|}
\hline SRM & Description & $\begin{array}{c}\text { Unit of } \\
\text { Issue }\end{array}$ \\
\hline 45d & Copper Secondary Freezing Point & $450 \mathrm{~g}$ \\
\hline 49e & Lead Secondary Freezing Point Standard & $600 \mathrm{~g}$ \\
\hline $\mathbf{7 4 2}$ & Aluminum Oxide Pyrometric Standard & $10 \mathrm{~g}$ \\
\hline
\end{tabular}

See Table 203.10 on the website for more information.

\section{Freezing Point, Melting Point, and Triple Point Cells (solid forms)}

These SRM fixed point devices are for use in the realization of internationally accepted secondary reference points and/ or triple points. They are not intended for calibration of differential scanning calorimeters.

\begin{tabular}{|l|l|c|}
\hline SRM & Description & $\begin{array}{c}\text { Unit of } \\
\text { Issue }\end{array}$ \\
\hline $\mathbf{1 9 6 8}$ & Gallium Melting-Point Standard & $25 \mathrm{~g}$ \\
\hline $\mathbf{1 9 7 0}$ & Succinonitrile Triple Point & $60 \mathrm{~g}$ \\
\hline $\mathbf{1 9 7 2}$ & 1,3-Dioxolan-2-one Triple Point & $60 \mathrm{~g}$ \\
\hline
\end{tabular}

See Table 203.11 on the website for more information.

\section{Thermocouple Materials}

\begin{tabular}{|l|l|c|}
\hline SRM & Description & $\begin{array}{c}\text { Unit of } \\
\text { Issue }\end{array}$ \\
\hline $\mathbf{1 7 4 9}$ & $\begin{array}{l}\text { Gold versus Platinum Thermocouple } \\
\text { Certified Thermometer }\end{array}$ & each \\
\hline $\mathbf{1 7 5 0}$ & $\begin{array}{l}\text { Standard Platinum Resistance } \\
\text { Thermometer Certified Thermometer }\end{array}$ & each \\
\hline $\mathbf{1 9 6 7 a}$ & $\begin{array}{l}\text { High-Purity Platinum Thermoelement } \\
\text { (platinum wire) }\end{array}$ & $0.51 \times 1 \mathrm{~m}$ \\
\hline
\end{tabular}

See Table 203.13 on the website for more information.

\section{Thermal Conductivity of Iron (rod form), Fibrous Glass, and Polystyrene}

\begin{tabular}{|l|l|c|}
\hline SRM & Description & $\begin{array}{c}\text { Unit of } \\
\text { Issue }\end{array}$ \\
\hline $\mathbf{1 4 5 0 d}$ & Thermal Conductivity, Fibrous Glass Board & each \\
\hline $\mathbf{1 4 5 3}$ & $\begin{array}{l}\text { Thermal Conductivity - } \\
\text { Expanded Polystyrene Board }\end{array}$ & each \\
\hline $\mathbf{8 4 2 0}$ & Electrolytic Iron & $0.64 \mathrm{D} \times 5.0$ \\
\hline
\end{tabular}

See Table 203.15 on the website for more information.

\section{Thermal Expansion of Glass (rod form)}

\begin{tabular}{|l|l|c|}
\hline SRM & Description & $\begin{array}{c}\text { Unit of } \\
\text { Issue }\end{array}$ \\
\hline 731L1 & Borosilicate Glass - Thermal Expansion & $5 \mathrm{~cm}$ \\
\hline 731L2 & Borosilicate Glass - Thermal Expansion & $10 \mathrm{~cm}$ \\
\hline 731L3 & Borosilicate Glass - Thermal Expansion & $15 \mathrm{~cm}$ \\
\hline
\end{tabular}

See Table 203.16 on the website for more information.

\section{Thermal Resistance Properties of Fibrous Glass and Fumed Silica Board}

\begin{tabular}{|l|l|c|}
\hline SRM & Description & $\begin{array}{c}\text { Unit of } \\
\text { Issue }\end{array}$ \\
\hline $\mathbf{1 4 4 9}$ & Thermal Resistance - Fumed Silica Board & each \\
\hline $\mathbf{1 4 5 2}$ & $\begin{array}{l}\text { Thermal Resistance - Fibrous Glass Blanket } \\
\text { for High Precision Measurements }\end{array}$ & each \\
\hline $\mathbf{1 4 5 9}$ & Thermal Resistance - Fumed Silica Board & each \\
\hline
\end{tabular}

See Table 203.17 on the website for more information.

\section{Thermoelectric Materials}

\begin{tabular}{|l|l|c|}
\hline SRM & Description & $\begin{array}{c}\text { Unit of } \\
\text { Issue }\end{array}$ \\
\hline 3451 & $\begin{array}{l}\text { Low Temperature Seebeck } \\
\text { Coefficient Standard }\end{array}$ & bar \\
\hline
\end{tabular}

See Table 203.18 on the website for more information.

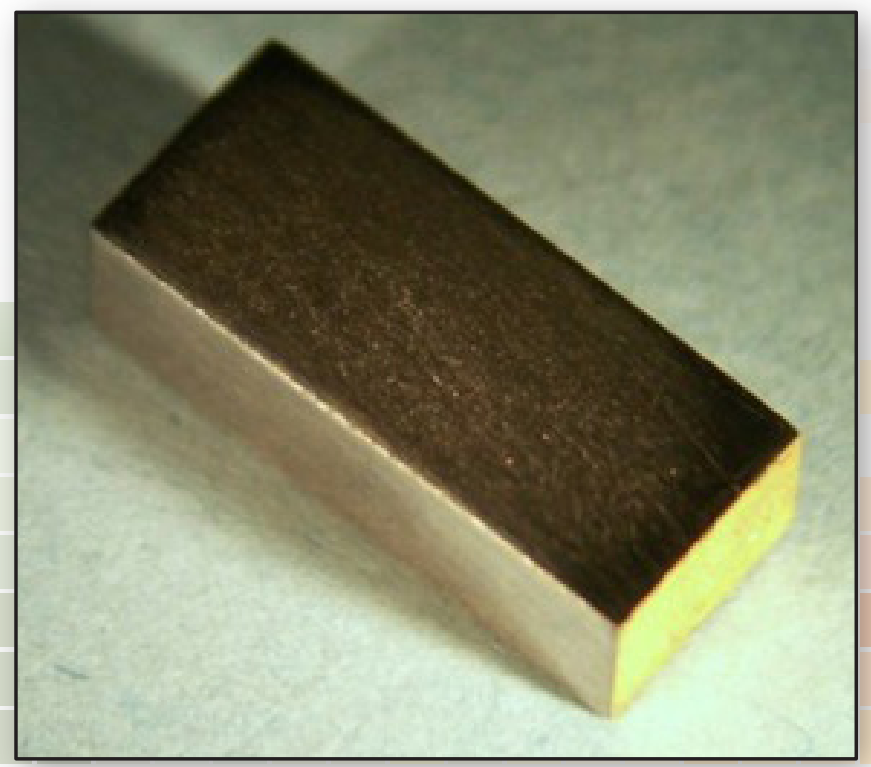

SRM 3451 Low-Termperature Seebeck Coefficient Standard 


\section{NIST Measurement Services Websites of Interest}

\section{Standard Reference Materials}

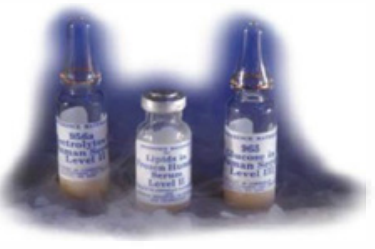

Standard Reference Materials

https://www.nist.gov/srm

Historical Archived Certificates/Reports of Investigation

https://www-s.nist.gov/srmors/certArchive.cfm

\section{Standard Reference Data}

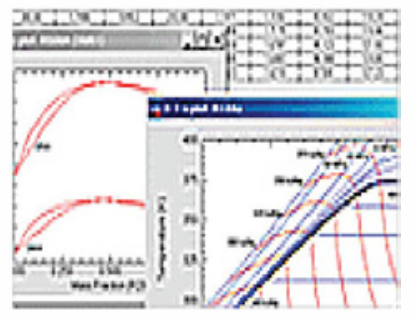

NIST Scientific and Technical Databases

https://www.nist.gov/srd

NIST Data Gateway

https://srdata.nist.gov/gateway

\section{Calibrations}

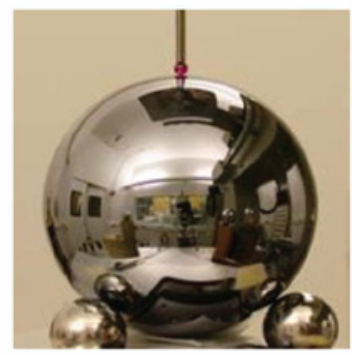

Calibrations Services

https://www.nist.gov/calibrations

Standard Reference Instruments

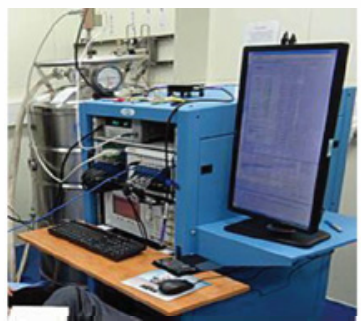

Standard Reference Instruments

https://www.nist.gov/srm/standard-reference-instruments.cfm 


\section{2}
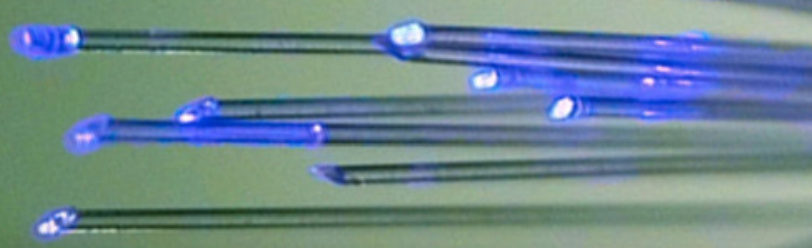

\section{Standard Reference Materials}

far Physical Properties

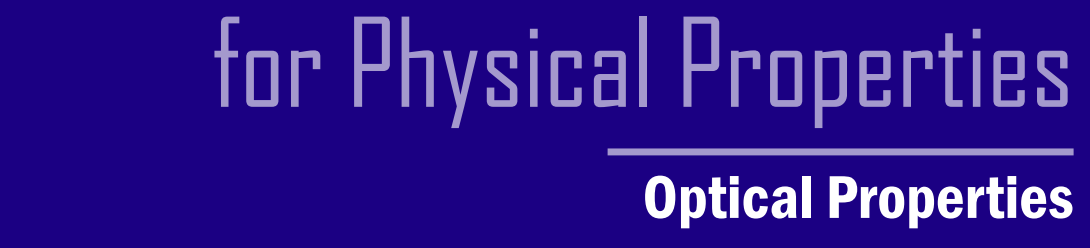

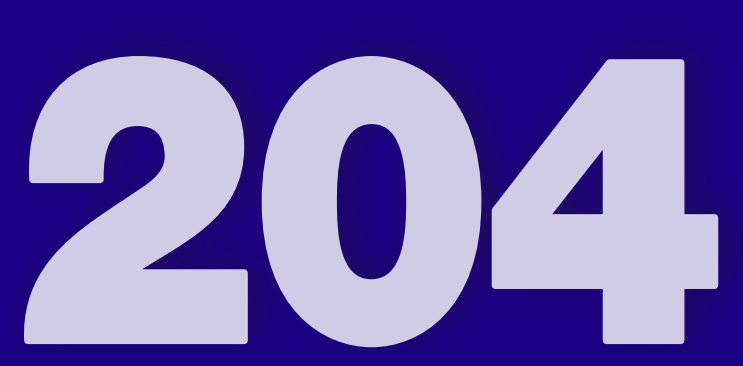




\section{Molecular Absorption (film, filter, solid, and solution forms)}

The optical SRMs for spectrophotometry are certified transfer standards that fall into three general categories: transmittance, wavelength, and stray radiant energy; each of which addresses a specific instrumental parameter of an absorption spectrometer that must be in control for accurate optical transmittance measurements. To obtain optimum verification results, each SRM must be used within the specified range of conditions for which it is intended.

\begin{tabular}{|l|l|c|}
\hline SRM & Description & $\begin{array}{c}\text { Unit of } \\
\text { Issue }\end{array}$ \\
\hline $\mathbf{9 3 1 h}$ & Liquid Absorbance Filters, UV-VIS & set (12) \\
\hline $\mathbf{9 3 5 a}$ & $\begin{array}{l}\text { Potassium Dichromate (Ultraviolet } \\
\text { Absorbance Standard) }\end{array}$ & $15 \mathrm{~g}$ \\
\hline $\mathbf{1 9 2 1 b}$ & $\begin{array}{l}\text { IR Transmission Wavelength } \\
\text { (Polystyrene Film) }\end{array}$ & 1 card \\
\hline $\mathbf{2 0 3 4}$ & $\begin{array}{l}\text { Metal-on-Fused-Silica Neutral Density } \\
\text { Filters (250 nm to 635 nm) }\end{array}$ & $\begin{array}{l}\text { Holmium Oxide Solution Wavelength } \\
\text { from 240 nm to 650 nm }\end{array}$ \\
\hline $\mathbf{2 0 3 5 a}$ & $\begin{array}{l}\text { Ultraviolet-Visible-Near-Infrared } \\
\text { Wavelength/Wavenumber Transmission } \\
\text { Standard }\end{array}$ & each \\
\hline $\mathbf{2 0 3 6}$ & $\begin{array}{l}\text { Near Infrared Wavelength/Wavenumber } \\
\text { Reflection Standard }\end{array}$ & each \\
\hline $\mathbf{2 0 8 2}$ & $\begin{array}{l}\text { Pathlength Absorbance Standards for } \\
\text { Microliter Volume Spectrophotometers }\end{array}$ & 3 vials \\
\hline
\end{tabular}

See Table 204.1 on the website for more information.

\section{Fluorescence and Raman Spectroscopy}

\begin{tabular}{|l|l|c|}
\hline SRM & Description & $\begin{array}{c}\text { Unit of } \\
\text { Issue }\end{array}$ \\
\hline $\mathbf{1 9 3 2}$ & Fluorescein Solution & $3 \times 2 \mathrm{~mL}$ \\
\hline $\mathbf{1 9 3 4}$ & $\begin{array}{l}\text { Fluorescent Dyes for Quantitative Flow } \\
\text { Cytometry (Visible Spectral Range) }\end{array}$ & ampoules \\
\hline $\mathbf{2 2 4 1}$ & $\begin{array}{l}\text { Relative Intensity Correction Standard } \\
\text { for Raman Spectroscopy: 785 nm Excitation }\end{array}$ & $\begin{array}{l}\text { Relative Intensity Correction Standard } \\
\text { for Raman Spectroscopy: 532 nm Excitation }\end{array}$ \\
\hline $\mathbf{2 2 4 4}$ & $\begin{array}{l}\text { Relative Intensity Correction Standard for } \\
\text { Raman Spectroscopy: 1064 nm Excitation }\end{array}$ & each \\
\hline $\mathbf{2 2 4 5}$ & $\begin{array}{l}\text { Relative Intensity Correction Standard } \\
\text { for Raman Spectroscopy: 633 nm Excitation }\end{array}$ & each \\
\hline $\mathbf{2 2 4 6}$ & $\begin{array}{l}\text { Relative Intensity Correction } \\
\text { Standard for Raman Spectroscopy: } \\
830 \text { nm Excitation }\end{array}$ & each \\
\hline
\end{tabular}

\begin{tabular}{|l|l|c|}
\hline SRM & Description & $\begin{array}{c}\text { Unit of } \\
\text { Issue }\end{array}$ \\
\hline $\mathbf{2 9 4 0}$ & $\begin{array}{l}\text { Relative Intensity Correction Standard } \\
\text { for Fluorescence Spectroscopy: } \\
\text { Orange Emission }\end{array}$ & each \\
\hline $\mathbf{2 9 4 1}$ & $\begin{array}{l}\text { Relative Intensity Correction Standard } \\
\text { for Fluorescence Spectroscopy: } \\
\text { Green Emission }\end{array}$ & each \\
\hline $\mathbf{2 9 4 2}$ & $\begin{array}{l}\text { Relative Intensity Correction Standard } \\
\text { for Fluorescence Spectroscopy: } \\
\text { Ultraviolet Emission }\end{array}$ & each \\
\hline $\mathbf{2 9 4 3}$ & $\begin{array}{l}\text { Relative Intensity Correction Standard } \\
\text { for Fluorescence Spectroscopy: } \\
\text { Blue Emission }\end{array}$ & $\begin{array}{l}\text { Relative Intensity Correction Standard } \\
\text { for Fluorescence Spectroscopy: } \\
\text { Red Emission }\end{array}$ \\
\hline
\end{tabular}

See Table 204.2 on the website for more information.

\section{Infrared Reflectance (solid form)}

\begin{tabular}{|l|l|c|}
\hline SRM & Description & $\begin{array}{c}\text { Unit of } \\
\text { Issue }\end{array}$ \\
\hline $\mathbf{2 0 3 6}$ & $\begin{array}{l}\text { Near Infrared Wavelength/ } \\
\text { Wavenumber Reflection Standard }\end{array}$ & each \\
\hline
\end{tabular}

See Table 204.2 on the website for more information.

\section{Optical Rotation (powder form)}

SRM $17 \mathrm{f}$ is intended for calibrating or checking polarimetric apparatus. In aqueous solution, the optical rotation of SRM $17 \mathrm{f}$ is value assigned at four wavelengths.

\begin{tabular}{|l|l|c|}
\hline SRM & Description & $\begin{array}{c}\text { Unit of } \\
\text { Issue }\end{array}$ \\
\hline $\mathbf{1 7 f}$ & Sucrose Optical Rotation & $60 \mathrm{~g}$ \\
\hline
\end{tabular}

See Table 204.2 on the website for more information.

\section{Photography (chart form)}

SRM 1010a is used to test the resolving power of cameras or of whole microcopying systems. It consists of 5 charts printed photographically on paper, that have 26 highcontrast, 5-line patterns ranging in spatial frequency of $1 \mathrm{~mm}^{-1}$ to $18 \mathrm{~mm}^{-1}$.

\begin{tabular}{|l|l|c|}
\hline SRM & Description & $\begin{array}{c}\text { Unit of } \\
\text { Issue }\end{array}$ \\
\hline 1010a & Microcopy Resolution Test Charts & set (5) \\
\hline
\end{tabular}



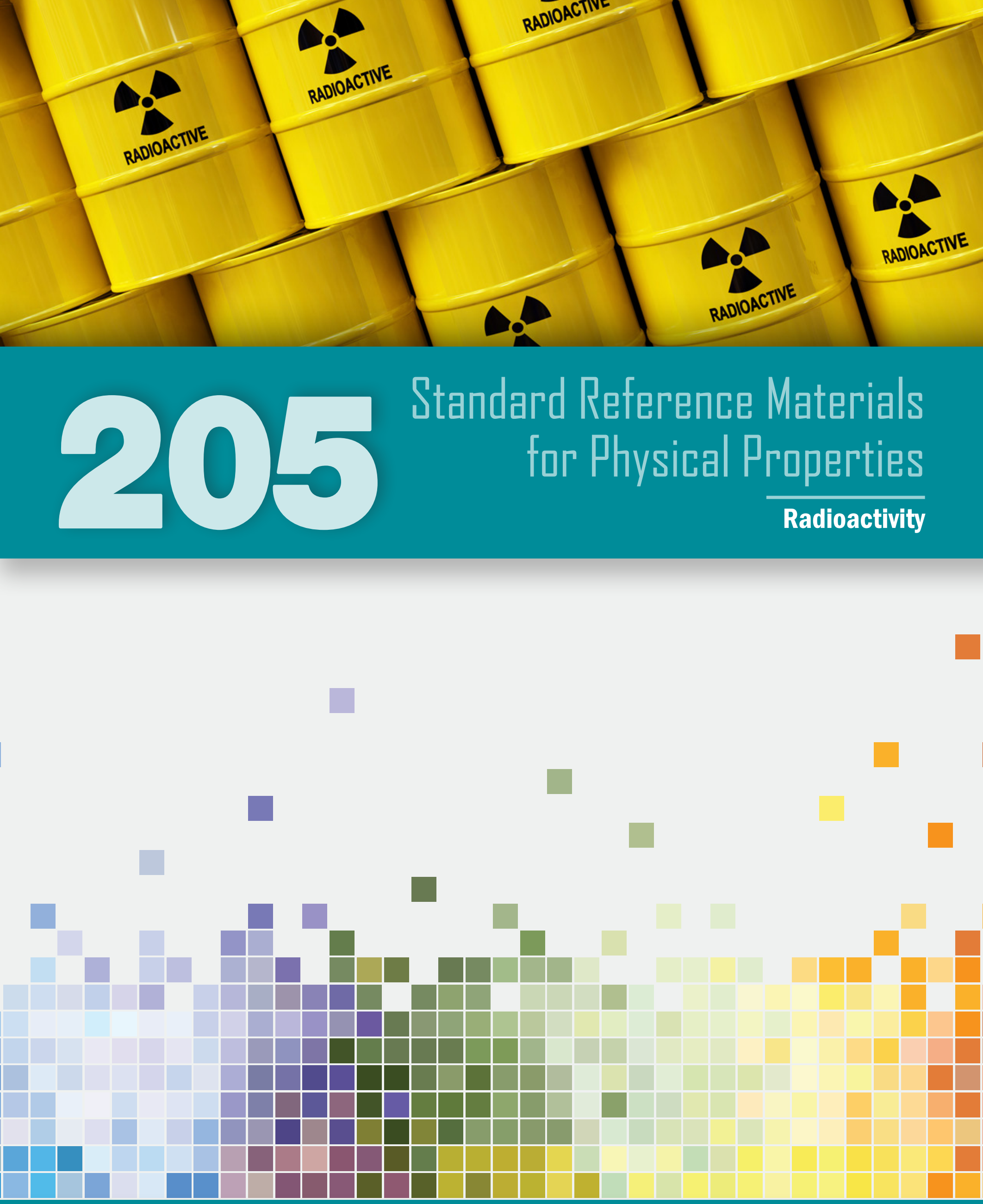

www.nist.gov/srm | Phone: 301.975.2200 | Fax: 301.948.3730 | Email: srminfo@nist.gov 


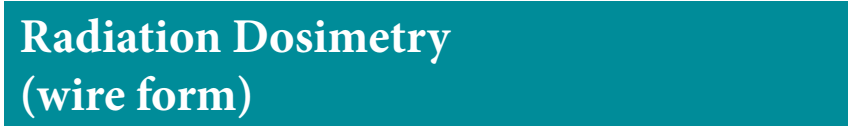

This SRM is a cobalt-in-aluminum alloy wire $0.5 \mathrm{~mm}$ in diameter and $1 \mathrm{~m}$ in length for use as a neutron density monitor standard.

"Radionuclide Calibration Services"

\begin{tabular}{|l|l|c|}
\hline SRM & Description & $\begin{array}{c}\text { Unit of } \\
\text { Issue }\end{array}$ \\
\hline $\mathbf{9 5 3}$ & Neutron Density Monitor Wire & $1 \mathrm{~m}$ \\
\hline
\end{tabular}

See Table 205.1 on the website for more information.

\section{Special Nuclear Materials}

The U.S. Department of Energy New Brunswick Laboratory issues special nuclear reference materials as NBL Certified Reference Materials (CRMs). These CRMs include the plutonium and uranium assay and isotopic materials previously issued by the National Institute of Standards and Technology. All orders or inquiries should be addressed to: U.S. Department of Energy, New Brunswick Laboratory, 9800 S. Cass Avenue, Bldg. 350, Argonne, IL 60439-4899. Attn: Reference Materials Sales; Phone (630) 252-2767; Fax (630) 252-6256; E-mail usdoe.nbl@ch.doe.gov

\section{Radioactive Solutions}

These SRMs are intended for the calibration of radioactivity measuring instruments and for the monitoring of chemical and geochemical processes. They are calibrated in terms of activity per gram of solution. Each SRM is contained in a flame-sealed glass ampoule or bottle and, except as noted, consists of the radionuclide dissolved in an aqueous solution (usually acidic).

When an import permit for radioactive material is required of a customer outside the U.S., NIST must have a copy to complete an order and facilitate shipment.

\begin{tabular}{|l|l|c|}
\hline SRM & Description & $\begin{array}{c}\text { Unit of } \\
\text { Issue }\end{array}$ \\
\hline 4222c & $\begin{array}{l}\text { Carbon-14 Radioactivity Standard for } \\
\text { Liquid Scintillation Counting }\end{array}$ & $5 \mathrm{~mL}$ \\
\hline 4226d & Nickel-63 Radioactivity Standard & $5 \mathrm{~mL}$ \\
\hline 4233e & $\begin{array}{l}\text { Cesium-137 Radioactivity } \\
\text { Standard Solution }\end{array}$ & $5 \mathrm{~mL}$ \\
\hline 4239 & $\begin{array}{l}\text { Strontium-90 Radioactivity } \\
\text { Standard Solution }\end{array}$ & $5 \mathrm{~mL}$ \\
\hline 4251C & $\begin{array}{l}\text { Barium-133 Radioactivity } \\
\text { Standard Solution }\end{array}$ \\
\hline
\end{tabular}

\begin{tabular}{|c|c|c|}
\hline SRM & Description & $\begin{array}{l}\text { Unit of } \\
\text { Issue }\end{array}$ \\
\hline 4274 & $\begin{array}{l}\text { Holmium-166m Gamma-ray } \\
\text { Emission Rate Standard Solution }\end{array}$ & $5 \mathrm{~mL}$ \\
\hline $4288 b$ & Technetium-99 Radioactivity Standard & $5 \mathrm{~mL}$ \\
\hline $4320 b$ & Curium-244 Radioactivity Standard & $5 \mathrm{~mL}$ \\
\hline $4321 c$ & $\begin{array}{l}\text { Natural Uranium Radioactivity } \\
\text { Standard Solution }\end{array}$ & $5 \mathrm{~mL}$ \\
\hline $4322 \mathrm{c}$ & Americium-241 Radioactivity Standard & $5 \mathrm{~mL}$ \\
\hline 4323b & Plutonium-238 Radioactivity Standard & $5 \mathrm{~mL}$ \\
\hline $4324 b$ & $\begin{array}{l}\text { Uranium-232 Radioactivity } \\
\text { Standard Solution }\end{array}$ & $5 \mathrm{~mL}$ \\
\hline $4326 a$ & Polonium-209 Radioactivity Standard & $5 \mathrm{~mL}$ \\
\hline $4328 \mathrm{c}$ & $\begin{array}{l}\text { Thorium-229 Radioactivity } \\
\text { Standard Solution }\end{array}$ & $5 \mathrm{~mL}$ \\
\hline 4329 & $\begin{array}{l}\text { Curium-243 Radioactivity } \\
\text { Standard Solution }\end{array}$ & $5 \mathrm{~mL}$ \\
\hline $4330 \mathrm{c}$ & Plutonium-239 Radioactivity Standard & $3 \mathrm{~mL}$ \\
\hline $4332 \mathrm{e}$ & Americium-243 Radioactivity Standard & $5 \mathrm{~mL}$ \\
\hline $4334 i$ & $\begin{array}{l}\text { Plutonium-242 Radioactivity } \\
\text { Standard Solution }\end{array}$ & $5 \mathrm{~mL}$ \\
\hline 4337 & Lead-210 Radioactivity Standard Solution & $5 \mathrm{~mL}$ \\
\hline $4338 a$ & $\begin{array}{l}\text { Plutonium-240 Radioactivity } \\
\text { Standard Solution }\end{array}$ & $5 \mathrm{~mL}$ \\
\hline 4339b & Radium-228 Radioactivity Solution & $5 \mathrm{~mL}$ \\
\hline $4340 \mathrm{~b}$ & Plutonium-241 Radioactivity Standard & $5 \mathrm{~mL}$ \\
\hline $4341 \mathrm{a}$ & Neptunium-237 Radioactivity Standard & $5 \mathrm{~mL}$ \\
\hline $4342 a$ & Thorium-230 Radioactivity Standard & $5 \mathrm{~mL}$ \\
\hline $4361 c$ & Hydrogen-3 Radioactivity Standard & $500 \mathrm{~mL}$ \\
\hline $4370 c$ & $\begin{array}{l}\text { Europium-152 Radioactivity } \\
\text { Standard Solution }\end{array}$ & $5 \mathrm{~mL}$ \\
\hline $4915 f$ & Cobalt-60 Radioactivity Standard Solution & $5 \mathrm{~mL}$ \\
\hline $4919 \mathrm{i}$ & Strontium-90 Radioactivity Standard & $5 \mathrm{~mL}$ \\
\hline $4926 \mathrm{e}$ & Hydrogen-3 Radioactivity Standard & $20 \mathrm{~mL}$ \\
\hline $4927 f$ & Hydrogen-3 Water Radioactivity Standard & $5 \mathrm{~mL}$ \\
\hline $4929 f$ & Iron-55 Radioactivity Standard & $5 \mathrm{~mL}$ \\
\hline 4943 & Chlorine-36 Radioactivity Standard & $3 \mathrm{~mL}$ \\
\hline 4949d & $\begin{array}{l}\text { Iodine-129 Radioactivity } \\
\text { Standard Solution }\end{array}$ & $5 \mathrm{~mL}$ \\
\hline 4965 & $\begin{array}{l}\text { Radium-226 Radioactivity } \\
\text { Standard Solution }\end{array}$ & $5 \mathrm{~mL}$ \\
\hline $4966 a$ & Radium-226 Radioactivity Standard & $5 \mathrm{~mL}$ \\
\hline $4967 a$ & $\begin{array}{l}\text { Radium-226 Radioactivity } \\
\text { Standard Solution }\end{array}$ & $5 \mathrm{~mL}$ \\
\hline 4969 & Radium-226 Radioactivity Standard & $5 \mathrm{~mL}$ \\
\hline
\end{tabular}

See Table 205.4 on the website for more information. 


\section{Radiopharmaceuticals (solution and gaseous forms)}

These SRMs are intended for the calibration of radioactivity-measuring instruments. They are calibrated in terms of activity per gram of solution (except SRM 4415, which is calibrated in terms of activity). Each SRM is contained in a $5 \mathrm{~mL}$ flame-sealed glass ampoule and, except for SRM 4415, consists of the radionuclide dissolved in an aqueous solution (usually acidic).These SRMs are produced in collaboration with the NRMAP, Inc. and, because of the short half lives, are available only at specific times.

When an import permit for radioactive material is required of a customer outside the U.S., NIST must have a copy to complete an order and facilitate shipment.

\begin{tabular}{|c|c|c|c|c|c|}
\hline SRM & Description & $\begin{array}{l}\text { Unit of } \\
\text { Issue }\end{array}$ & $\begin{array}{l}\text { Approximate } \\
\text { Activity }\end{array}$ & $\begin{array}{l}\text { Half Life } \\
\text { (days) }\end{array}$ & Month Produced ${ }^{*}$ \\
\hline $4401 \mathrm{~L}$ & Iodine-131 Radioactivity Standard & $5 \mathrm{~mL}$ & $5 \mathrm{MBq} / \mathrm{g}$ & 8 & February \\
\hline $4401 H^{* *}$ & Iodine-131 Radioactivity Standard & $5 \mathrm{~mL}$ & $600 \mathrm{MBq} / \mathrm{g}$ & 8 & February \\
\hline $4404 \mathrm{~L}$ & Thallium-201 Radioactivity Standard & $5 \mathrm{~mL}$ & $10 \mathrm{MBq} / \mathrm{g}$ & 3 & June \\
\hline $4404 H^{* *}$ & Thallium-201 Radioactivity Standard & $5 \mathrm{~mL}$ & $500 \mathrm{MBq} / \mathrm{g}$ & 3 & June \\
\hline $4407 \mathrm{~L}$ & Iodine-125 Radioactivity Standard & $5 \mathrm{~mL}$ & $5 \mathrm{MBq} / \mathrm{g}$ & 59.4 & December \\
\hline $4407 H^{* *}$ & Iodine-125 Radioactivity Standard & $5 \mathrm{~mL}$ & $370 \mathrm{MBq} / \mathrm{g}$ & 59.4 & December \\
\hline $4410 \mathrm{H}$ & Technetium-99m Radioactivity Standard & $5 \mathrm{~mL}$ & $1.0 \mathrm{GBq} / \mathrm{g}$ & 0.3 & September \\
\hline $4412 \mathrm{~L}$ & Molybdenum-99 Radioactivity Standard & $5 \mathrm{~mL}$ & $10 \mathrm{MBq} / \mathrm{g}$ & 2.74 & April \\
\hline $4412 H^{* *}$ & Molybdenum-99 Radioactivity Standard & $5 \mathrm{~mL}$ & $700 \mathrm{Mbq} / \mathrm{g}$ & 2.74 & April \\
\hline $4415 \mathrm{~L}$ & Xenon-133 Radioactivity Standard & $5 \mathrm{~mL}$ & $150 \mathrm{MBq} / \mathrm{g}$ & 5.243 & September \\
\hline $4415 H^{* *}$ & Xenon-133 Radioactivity Standard & $5 \mathrm{~mL}$ & $12 \mathrm{GBq} / \mathrm{g}$ & 5.243 & September \\
\hline $4416 \mathrm{~L}$ & Gallium-67 Radioactivity Standard & $5 \mathrm{~mL}$ & $5 \mathrm{MBq} / \mathrm{g}$ & 3.3 & May \\
\hline $4416 \mathrm{H}^{\star *}$ & Gallium-67 Radioactivity Standard & $5 \mathrm{~mL}$ & $370 \mathrm{MBq} / \mathrm{g}$ & 3.3 & May \\
\hline $4417 \mathrm{~L}$ & Indium-111 Radioactivity Standard & $5 \mathrm{~mL}$ & $10 \mathrm{MBq} / \mathrm{g}$ & 2.8 & August \\
\hline $4417 H^{* *}$ & Indium-111 Radioactivity Standard & $5 \mathrm{~mL}$ & $500 \mathrm{MBq} / \mathrm{g}$ & 2.8 & August \\
\hline $4427 \mathrm{~L}$ & Yttrium-90 Radioactivity Standard & $5 \mathrm{~mL}$ & $5 \mathrm{MBq} / \mathrm{g}$ & 2.67 & October \\
\hline $4427 H^{* *}$ & Yttrium-90 Radioactivity Standard & $5 \mathrm{~mL}$ & $50 \mathrm{MBq} / \mathrm{g}$ & 2.67 & October \\
\hline
\end{tabular}

See Table 205.5 on the website for more information.

${ }^{*}$ Check the website for details as to the order date deadline for these SRMs.

${ }^{* *}$ Only available to members of NRMAP, Inc. For information on membership: NRMAP/NIST Program https://www-s.nist.gov/srmors/certificates/documents/ NRMAP-PharmBroch2012.pdf 
Carbon-14 Dating

(solid form)

This SRM is an international standard for contemporary carbon-14 against which world-wide measurements can be compared. Each SRM consists of approximately $225 \mathrm{~g}$ of a $450 \mathrm{~kg}$ lot of oxalic acid prepared by fermentation of French beet molasses from the 1977 spring, summer, and autumn harvests.

\begin{tabular}{|l|l|c|}
\hline SRM & Description & $\begin{array}{c}\text { Unit of } \\
\text { Issue }\end{array}$ \\
\hline 4990c & Oxalic Acid & $8 \times 28 \mathrm{~g}$ \\
\hline
\end{tabular}

See Table 205.7 on the website for more information.

\section{Radioactive Natural Matrix Materials (powder form)}

When an import permit for radioactive material is required of a customer outside the U.S., NIST must have a copy to complete an order and facilitate shipment.

\begin{tabular}{|l|l|c|}
\hline SRM & Description & $\begin{array}{c}\text { Unit of } \\
\text { Issue }\end{array}$ \\
\hline $\mathbf{4 3 5 0 b}$ & $\begin{array}{l}\text { River Sediment Environmental } \\
\text { Radioactivity Standard }\end{array}$ & $85 \mathrm{~g}$ \\
\hline $\mathbf{4 3 5 1}$ & $\begin{array}{l}\text { Human Lung Environmental } \\
\text { Radioactivity Standard }\end{array}$ & $45 \mathrm{~g}$ \\
\hline $\mathbf{4 3 5 2}$ & Human Liver Powder & $45 \mathrm{~g}$ \\
\hline $\mathbf{4 3 5 3 a}$ & Rocky Flats Soil Number 2 & $90 \mathrm{~g}$ \\
\hline $\mathbf{4 3 5 4}$ & Lake Sediment Powder & $25 \mathrm{~g}$ \\
\hline $\mathbf{4 3 5 5}$ & Peruvian Soil Powder & $75 \mathrm{~g}$ \\
\hline $\mathbf{4 3 5 6}$ & Ashed Bone (Radioactivity) & $15 \mathrm{~g}$ \\
\hline $\mathbf{4 3 5 7}$ & Ocean Sediment Powder & $85 \mathrm{~g}$ \\
\hline $\mathbf{4 3 5 8}$ & Ocean Shellfish Radionuclide Standard & $150 \mathrm{~g}$ \\
\hline $\mathbf{4 3 5 9}$ & Seaweed Radionuclide Standard & $300 \mathrm{~g}$ \\
\hline
\end{tabular}

See Table 205.11 on the website for more information.

\section{Considering a Radioactive SRM(s) Order?}

Start by submitting a request to our SRM Sales Office, via email (srminfo@nist.gov) or fax (301-948-3730). After it has been received, you will be contacted for any additional information needed. Based on the regulations that apply to you as a customer either within the United States (United States includes Puerto Rico and all territories and possessions of the United States) or outside the United States, NIST will determine if your request can be cleared for processing. Requirements for the different customer locations are outlined below.

\section{Customers in Organizations within the United States:}

If the material(s) requested is/are subject to license requirements by the Nuclear Regulatory Commission (NRC). Prior to shipment, NIST is required by law to verify the domestic customer's authorization to receive and possess radioactive material. Once NIST makes a determination, you will be notified with the disposition of your request. For approved requests, your order confirmation or quote will be forwarded to you.

\section{Customers in Organizations outside the United States:}

- Import permit for radioactive material: Your country may require an import permit for radioactive material. Prior confirmation of your import permit status is necessary for the disposition of your request.

If your country requires an import permit, NIST must have a copy in order to complete your order and facilitate shipment with the carrier.

- Export controls: NIST is required to determine if your country is subject to export controls as determined by the Nuclear Regulatory Commission (NRC) and the U.S. Department of Commerce, Bureau of Industry and Security. NIST will review those controls and determine the disposition of your request.

- Once NIST has received your import permit (if applicable) and approved your request for export, your order confirmation or quote will be forwarded.

If you have any technical questions, please contact the NIST Radiation Physics Division at radsrms@nist.gov. 


\section{2}

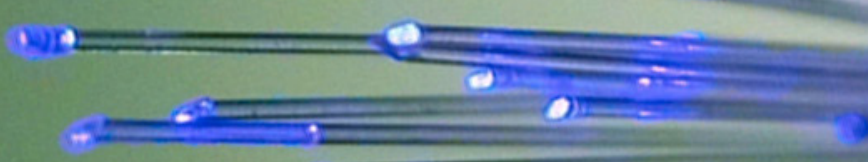

$x^{2}=$

\section{Standard Reference Materials}

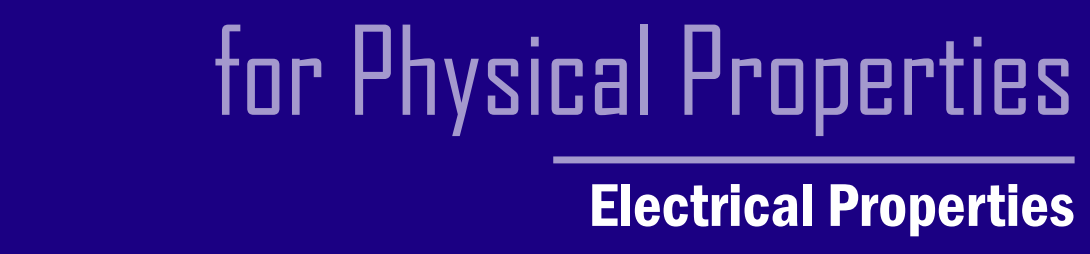

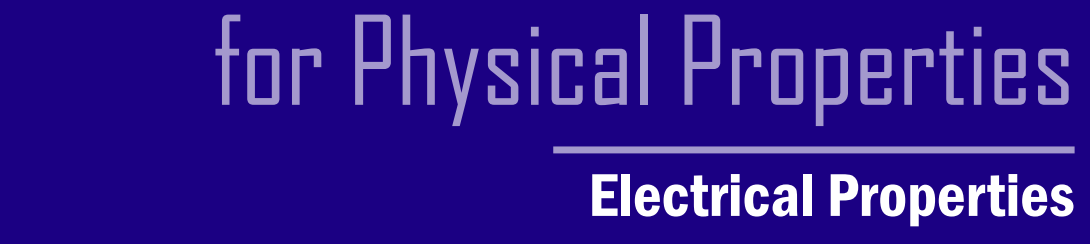

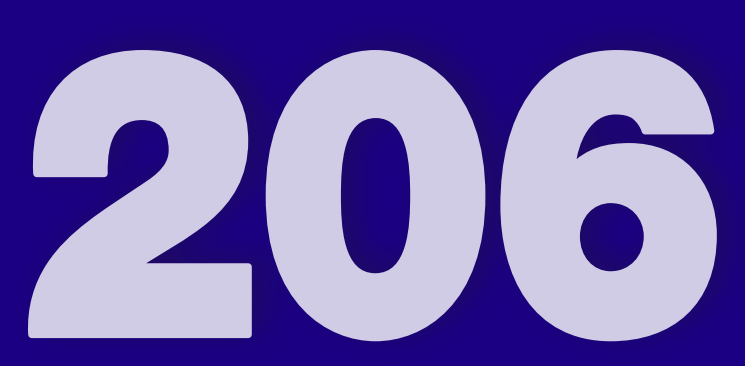




\section{Electrical Resistivity and Conductivity of Iron (rod form)}

\begin{tabular}{|l|l|c|}
\hline SRM & Description & $\begin{array}{c}\text { Unit of } \\
\text { Issue }\end{array}$ \\
\hline $\mathbf{8 4 2 0}$ & Electrolytic Iron & $0.64 \mathrm{D} \times 5.0$ \\
\hline
\end{tabular}

See Table 206.1 on the website for more information.

\section{Electrical Resistivity and Conductivity of Silicon (block and wafer forms)}

SRMs 2541 and 2543 consist of single wafers intended for use as reference standards for sheet resistance and resistivity measurements utilizing the four-point probe method. SRMs 2543 are made of Czochralski-grown, boron-doped silicon with (100) crystallographic orientation.

\begin{tabular}{|l|l|c|}
\hline SRM & Description & $\begin{array}{c}\text { Unit of } \\
\text { Issue }\end{array}$ \\
\hline $\mathbf{2 5 4 1}$ & $\begin{array}{l}\text { Silicon Resistivity Standard - } \\
0.01 \mathrm{ohm} \bullet \mathrm{cm} \text { Level }\end{array}$ & each \\
\hline $\mathbf{2 5 4 3}$ & $\begin{array}{l}\text { Silicon Resistivity Standard - } \\
1 \mathrm{ohm} \cdot \mathrm{cm} \text { Level }\end{array}$ & each \\
\hline
\end{tabular}

See Table 206.2 on the website for more information.

\section{Superconducting Critical Current} (wire form)

This SRM is for checking the performance of measurement systems used in superconductor technology. It consists of $2.2 \mathrm{~m}$ of a multifilamentary niobium titanium, copper-stabilized superconducting wire wound in a single layer onto a spool with a core diameter of $8.7 \mathrm{~cm}$.

\begin{tabular}{|l|l|c|}
\hline SRM & Description & $\begin{array}{c}\text { Unit of } \\
\text { Issue }\end{array}$ \\
\hline $\mathbf{1 4 5 7}$ & $\begin{array}{l}\text { Superconducting Critical Current - } \\
\text { Nb Ti Wire }\end{array}$ & each \\
\hline
\end{tabular}

See Table 206.4 on the website for more information. 


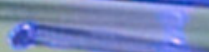

(c)

\section{Standard Reference Materials} far Physical Praperties $\frac{\text { Metrology }}{\text { s. }}$ fог Physical Pгорегties

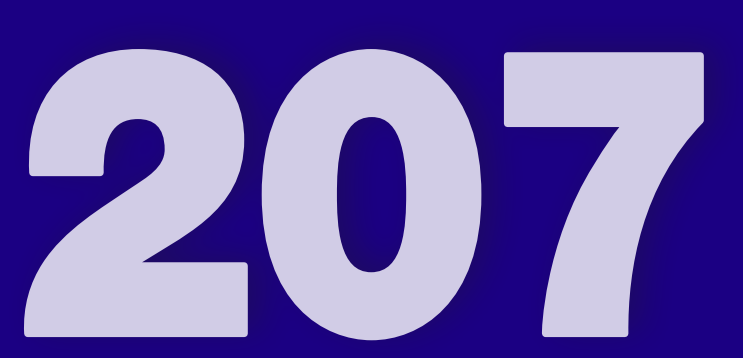




\section{Scanning Electron Microscope (SEM)}

These RMs are for calibrating the magnification scale and evaluating the performance of scanning electron microscopes. RM 8091 is used in checking the sharpness performance of scanning electron microscopes.

\begin{tabular}{|l|l|c|}
\hline SRM & Description & $\begin{array}{c}\text { Unit of } \\
\text { Issue }\end{array}$ \\
\hline $\mathbf{8 0 9 1}$ & $\begin{array}{l}\text { Scanning Electron Microscope } \\
\text { Sharpness Standard }\end{array}$ & each \\
\hline $\mathbf{8 8 2 0}$ & $\begin{array}{l}\text { Scanning Electron Microscope Scale } \\
\text { Calibration Artifact }\end{array}$ & each \\
\hline
\end{tabular}

See Table 207.1 on the website for more information.

\section{Depth Profiling (wafer form)}

SRMs 2133, 2134 and 2137 are for calibrating the secondary ion response to minor and trace element levels in a silicon matrix. SRM 2133 is certified for phosphorus; SRM 2134 is certified for arsenic; SRM 2137 is certified for boron. SRM $2135 \mathrm{c}$ is for calibrating equipment used to measure sputtered depth and erosion rates in surface analysis. SRM 2135c is certified for total chromium and total nickel thickness, for individual layer uniformity, for nickel/chromium bilayer uniformity, and for individual layer thickness.

\begin{tabular}{|l|l|c|}
\hline SRM & Description & $\begin{array}{c}\text { Unit of } \\
\text { Issue }\end{array}$ \\
\hline $\mathbf{2 1 3 3}$ & Phosphorus Implant in Si Depth Profile & each \\
\hline $\mathbf{2 1 3 4}$ & $\begin{array}{l}\text { Arsenic Implant in Silicon Depth } \\
\text { Profile Standard }\end{array}$ & each \\
\hline $\mathbf{2 1 3 5 c}$ & Ni/Cr Thin Film Depth Profile & each \\
\hline $\mathbf{2 1 3 7}$ & $\begin{array}{l}\text { Boron Implant in Silicon Standard } \\
\text { for Calibration of Concentration in } \\
\text { a Depth Profile }\end{array}$ & each \\
\hline
\end{tabular}

See Table 207.3 on the website for more information.

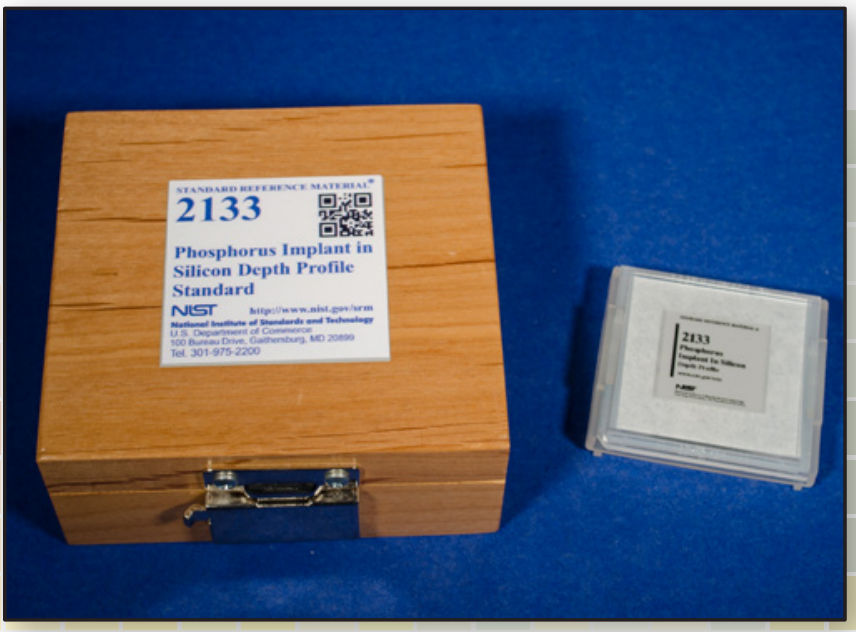

\section{Optoelectronics} (solid forms)

These SRMs are intended for calibrating equipment (tunable diode lasers, video microscopes, optical spectrum analyzers, etc.) and measurement systems used in optoelectronics manufacturing and in the testing of optoelectronics components (lasers and detectors, optical fiber and fiber components, etc.). SRMs 2514, 2515, 2517a and 2519a are fiber-connected molecular gas absorption cells with lines in the 1510 to $1630 \mathrm{~nm}$ region. SRM 2520 is an optical fiber specimen with a known cladding diameter value.

\begin{tabular}{|l|l|c|}
\hline SRM & Description & $\begin{array}{c}\text { Unit of } \\
\text { Issue }\end{array}$ \\
\hline $\mathbf{2 5 1 4}$ & $\begin{array}{l}\text { Wavelength Calibration Reference } \\
\text { for } 1560 \mathrm{~nm} \text { to } 1595 \mathrm{~nm}\end{array}$ & each \\
\hline $\mathbf{2 5 1 5}$ & $\begin{array}{l}\text { Wavelength Calibration Reference } \\
\text { for } 1595 \mathrm{~nm} \text { to } 1630 \mathrm{~nm}\end{array}$ & each \\
\hline $\mathbf{2 5 1 7 a}$ & $\begin{array}{l}\text { High Resolution Wavelength Calibration } \\
\text { Reference for 1510 to 1540 nm Acetylene } \\
{ }^{12} \mathrm{C}_{2} \mathrm{H}_{2}\end{array}$ & each \\
\hline $\mathbf{2 5 1 9 a}$ & $\begin{array}{l}\text { High Resolution Wavelength Calibration } \\
\text { Reference for 1530 nm -1565 nm Hydrogen } \\
\text { Cyanide }\end{array}$ & each \\
\hline $\mathbf{2 5 2 0}$ & $\begin{array}{l}\text { Optical Fiber Diameter Standard } \\
\mathbf{2 5 5 3}\end{array}$ & $\begin{array}{l}\text { Optical Fiber Coating Diameter } \\
\text { (Nominal Refractive Index 1.504) }\end{array}$ \\
\hline $\mathbf{2 5 5 4}$ & $\begin{array}{l}\text { Optical Fiber Coating Diameter } \\
\text { (Nominal Refractive Index 1.515) }\end{array}$ & each \\
\hline
\end{tabular}

See Table 207.4 on the website for more information.

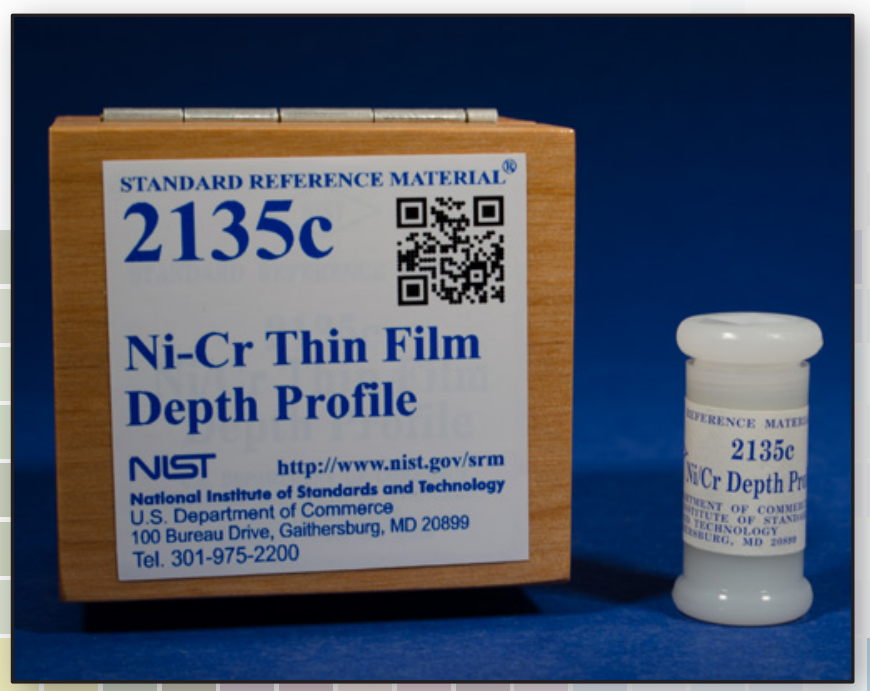




\section{Nonmagnetic Coating Thickness (plate form)}

These SRMs are suitable for calibrating instruments used in the measurement of organics and nonmagnetic inorganic coatings over steel. They consist of fine grained copper of varying thicknesses electrodeposited onto low carbon steel substrates having the properties of AISI 1010 steel. These uniform coatings are then overplated with a thin protective layer of chromium and the total coating thickness is then certified. The thickness range covered is between $6 \mu \mathrm{m}$ and $2000 \mu \mathrm{m}$. Each unit is also supplied with a blank substrate.

\begin{tabular}{|l|l|c|}
\hline SRM & Description & $\begin{array}{c}\text { Unit of } \\
\text { Issue }\end{array}$ \\
\hline 1358b & $\begin{array}{l}\text { Coating Thickness Standard, } \\
\text { (Nonmagnetic Coating on Steel) }\end{array}$ & set (5) \\
\hline 1359b & $\begin{array}{l}\text { Coating Thickness Standard } \\
\text { (Nonmagnetic Coating on Steel) }\end{array}$ & set (5) \\
\hline 1361b & $\begin{array}{l}\text { Coating Thickness Standard } \\
\text { (Nonmagnetic Coating on Steel) }\end{array}$ \\
\hline 1362b & $\begin{array}{l}\text { Coating Thickness Standard } \\
\text { (Nonmagnetic Coating on Steel) }\end{array}$ & $\begin{array}{l}\text { Coating Thickness Standard } \\
\text { (Nonmagnetic Coating on Steel) }\end{array}$ \\
\hline 1364b & $\begin{array}{l}\text { Coating Thickness Standard } \\
\text { (Nonmagnetic Coating on Steel) }\end{array}$ & set (5) \\
\hline
\end{tabular}

See Table 207.5 on the website for more information.

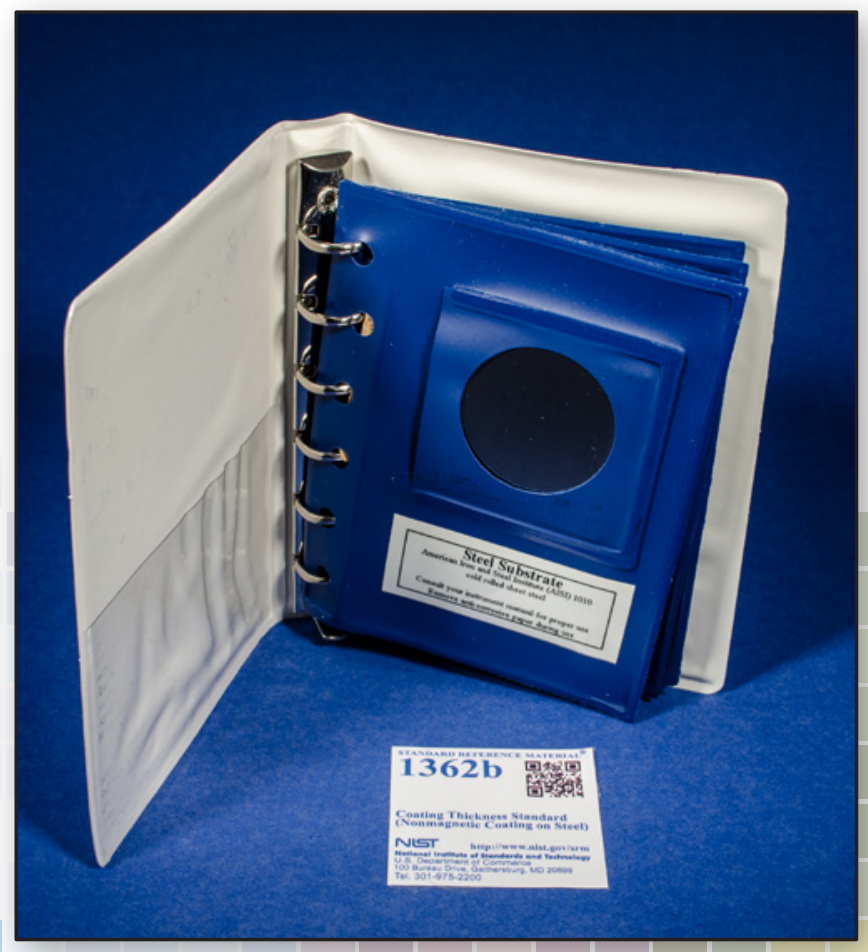

\section{Microscale Dimensional \\ Measurement Standards}

SRM 5001 is intended primarily for calibrating high accuracy two dimensional (X-Y) Photomask/Reticle registration metrology tools. In particular, this calibration artifact can also be used in the metrology tools capable of holding any artifact with these dimensions in need of a calibrated measurement field. An example of additional tools are defect inspection and classification tools, optical tools used in manufacture of flat panel displays or scanning electron microscopy tools used in photomask and wafer inspection.

\begin{tabular}{|l|l|c|}
\hline SRM & Description & $\begin{array}{c}\text { Unit of } \\
\text { Issue }\end{array}$ \\
\hline $\mathbf{5 0 0 1}$ & $\begin{array}{l}\text { Two-Dimensional Grid Photomask } \\
\text { Standard }\end{array}$ & each \\
\hline $\mathbf{8 8 2 0}$ & $\begin{array}{l}\text { Scanning Electron Microscope Scale } \\
\text { Calibration Artifact }\end{array}$ & each \\
\hline
\end{tabular}

See Table 207.9 on the website for more information.

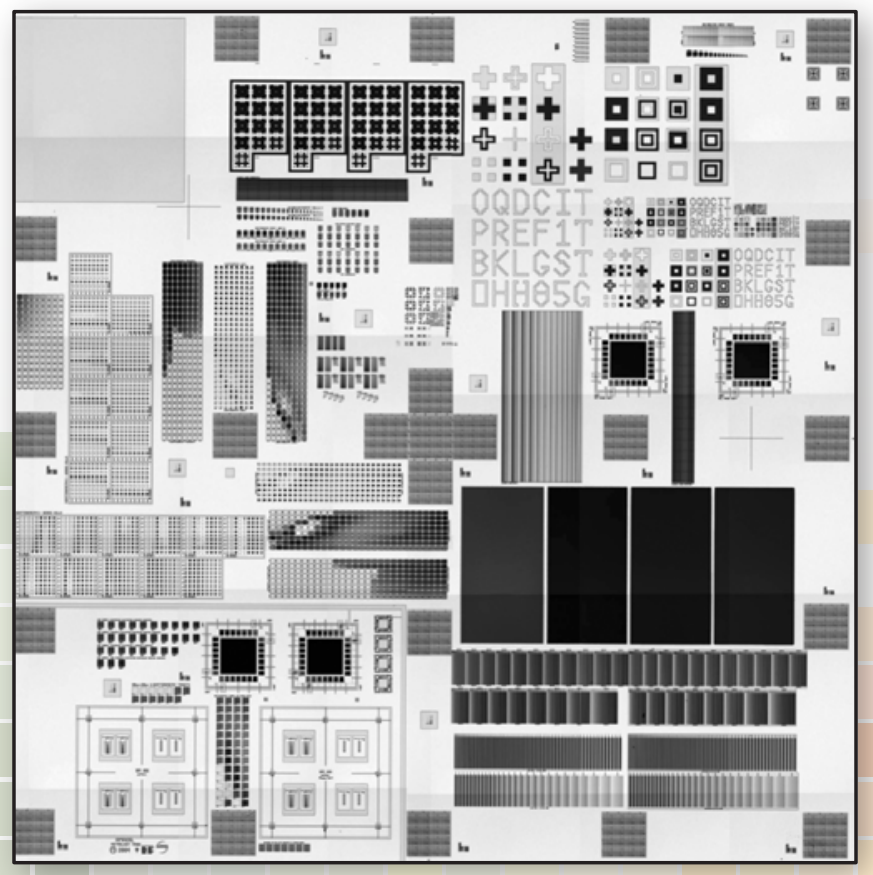

RM 8820. Optical microscope view of the $20 \mathrm{~mm} \times 20 \mathrm{~mm}$ chip. 


\section{SRMTERTERT}

\section{Would you like to be on our mailing list to receive updates of our Standard Reference Materials (SRMs)?}

Join our mailing list to receive the SRM Spotlight newsletter which features information on our newly released SRMs, renewals and revisions. It also includes our exhibit schedule along with other helpful resources.

Sign up on our homepage at https://www.nist.gov/srm under SRM Spotlight.
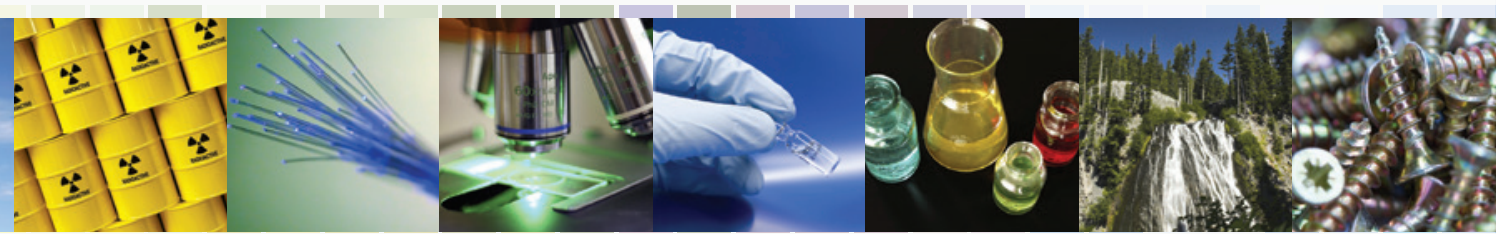

www.nist.gov/srm 


\section{2}
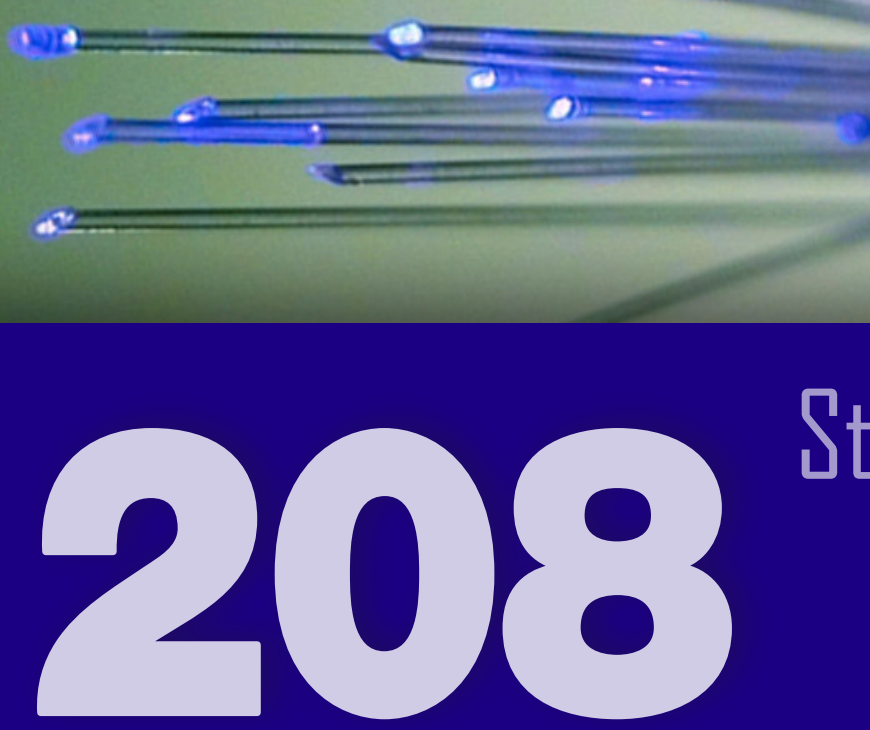

\section{Standard Reference Materials}

for Physical Properties Liquids \& Glasses 


\section{Chemical Resistance [Durability] of Glass (solid form)}

This SRM is for checking test methods and calibrating equipment used to determine the resistance of glass containers to chemical attack.

\begin{tabular}{|l|l|c|}
\hline SRM & Description & $\begin{array}{c}\text { Unit of } \\
\text { Issue }\end{array}$ \\
\hline 622 & Soda-Lime-Silica Glass & $2.2 \mathrm{~kg}$ \\
\hline
\end{tabular}

See Table 208.1 on the website for more information.

\section{Electrical Properties of Dielectrics}

SRM 624 is intended to validate test methods and for calibrating equipment used to determine the dc volume resistivity of glass per ASTM C 657.

SRM 2870 is a cross-linked polystyrene puck that is intended to validate techniques used to measure the high-frequency relative permittivity and loss tangent of insulating materials. Certified values for relative permittivity and loss tangent are specified at $10 \mathrm{GHz}$, including supplemental data between $1 \mathrm{GHz}$ and $25 \mathrm{GHz}$.

\begin{tabular}{|l|l|c|}
\hline SRM & Description & $\begin{array}{c}\text { Unit of } \\
\text { Issue }\end{array}$ \\
\hline $\mathbf{6 2 4}$ & Lead-Silica Glass for dc Volume Resistivity & $200 \mathrm{~g}$ \\
\hline $\mathbf{2 8 7 0}$ & $\begin{array}{l}\text { Relative Permittivity and Loss Tangent } \\
1422 \text { Cross-Linked Polystyrene }\end{array}$ & $\begin{array}{c}\text { circular- } \\
\text { cylindrical } \\
\text { puck }\end{array}$ \\
\hline
\end{tabular}

See Table 208.2 on the website for more information.

\section{Viscosity of Glass (bar form)}

SRM 717a is for checking the performance of high temperature viscosity equipment (rotating cylinders) and low temperature viscosity equipment (fiber elongation, beam bending, parallel plates, etc.).

\begin{tabular}{|l|l|c|}
\hline SRM & Description & $\begin{array}{c}\text { Unit of } \\
\text { Issue }\end{array}$ \\
\hline 717a & Hi Boron Glass Viscosity & block \\
\hline
\end{tabular}

See Table 208.3 on the website for more information.

\section{Glass Liquidus Temperature (solid form)}

This SRM is for checking test methods and for calibrating equipment used to determine the liquidus temperature of glass by the gradient furnace methods per ASTM C 829.

\begin{tabular}{|l|l|c|}
\hline SRM & Description & $\begin{array}{c}\text { Unit of } \\
\text { Issue }\end{array}$ \\
\hline $\mathbf{1 4 1 6}$ & $\begin{array}{l}\text { Aluminosilicate Glass for } \\
\text { Liquidus Temperature }\end{array}$ & $250 \mathrm{~g}$ \\
\hline
\end{tabular}

See Table 208.4 on the website for more information.

\section{Viscosity Fixpoints (solid forms)}

These SRMs are for the calibration of equipment for the determination of the softening, annealing, and strain points of glass.

\begin{tabular}{|l|l|c|}
\hline SRM & Description & $\begin{array}{c}\text { Unit of } \\
\text { Issue }\end{array}$ \\
\hline $\mathbf{7 0 9}$ & Extra Dense Lead Glass & block \\
\hline $\mathbf{7 1 7 a}$ & Borosilicate Glass & block \\
\hline
\end{tabular}

See Table 208.5 on the website for more information.

\section{Relative Stress Optical Coefficient (bar form)}

\begin{tabular}{|l|l|c|}
\hline SRM & Description & $\begin{array}{c}\text { Unit of } \\
\text { Issue }\end{array}$ \\
\hline $\mathbf{7 0 9}$ & Extra Dense Lead Glass & block \\
\hline
\end{tabular}

See Table 208.6 on the website for more information.

\section{Density}

SRMs $211 \mathrm{~d}$ and 2214 are for reference in the determination of the density of liquids. The certified densities were determined by means of hydrostatic weighing and are provided at $15^{\circ} \mathrm{C}, 20^{\circ} \mathrm{C}$, and $25^{\circ} \mathrm{C}$

\begin{tabular}{|l|l|c|}
\hline SRM & Description & $\begin{array}{c}\text { Unit of } \\
\text { Issue }\end{array}$ \\
\hline 211d & Toluene Liquid Density - Extended Range & $4 \times 5 \mathrm{~mL}$ \\
\hline $\mathbf{2 2 1 4}$ & Isooctane Liquid Density & $4 \times 5 \mathrm{~mL}$ \\
\hline
\end{tabular}

See Table 208.8 on the website for more information. 


\section{2}
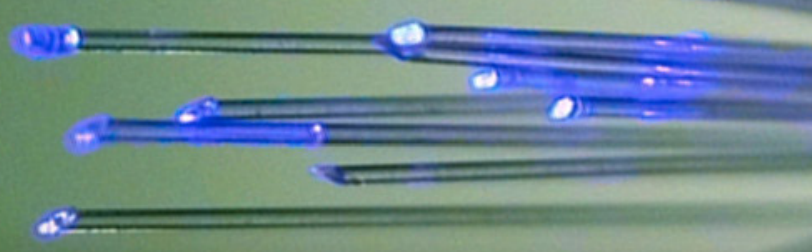

\section{Standard Reference Materials}

far Physical Рroperties fрг Physical Ргрperties

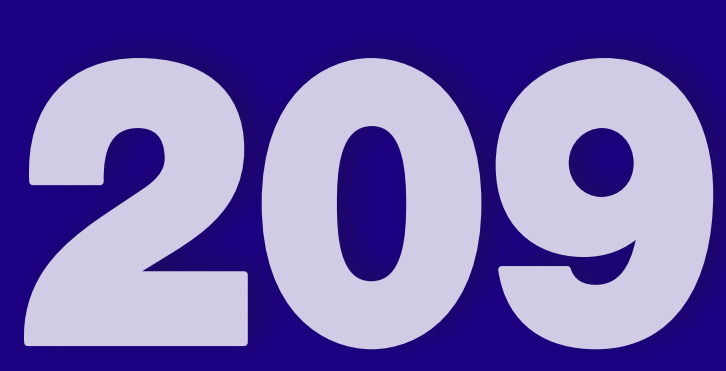




\section{X-Ray Diffraction \\ (powder and solid forms)}

SRMs $656,676 \mathrm{a}, 674 \mathrm{~b}, 1878 \mathrm{~b}$, and $1879 \mathrm{~b}$ consist of high phase purity materials for use in the quantitative analysis of samples by the internal standard method. SRM 656 consists of 2 silicon nitride powders, one high in a, the other high in b. SRMs 640e, 660c, 675 , and 1976b consist of materials with select crystallographic and microstructure properties used in the evaluation of diffraction equipment for the following variables; 1) d-spacing or line position, 2) line or instrument intensity, and 3) instrumental or sample contributions to the shape of reflection profiles. SRM 1976b, a sintered alumina plate, is also certified with respect to lattice parameters as well as 13 relative intensity values from $22^{\circ}$ to $155^{\circ} 2 \mathrm{q}(\mathrm{Cu} \mathrm{K \alpha})$. SRM 1990 is certified for lattice parameter. SRM 1994 is certified for mis-orientation of the crystal axis relative to the surface normal.

\begin{tabular}{|l|l|c|}
\hline SRM & Description & Unit of Issue \\
\hline $\mathbf{6 4 0 e}$ & Line Position and Line Shape Standard for Powder Diffraction (Silicon Powder) & $7.5 \mathrm{~g}$ \\
\hline $\mathbf{6 5 6}$ & Silicon Nitride for Quantitative Analysis by Powder Diffraction & $2 \mathrm{x} 10 \mathrm{~g}$ \\
\hline $\mathbf{6 6 0 c}$ & Line Position and Line Shape Standard for Powder Diffraction (Lanthanum Hexaboride Powder) & $6 \mathrm{~g}$ \\
\hline $\mathbf{6 7 4 b}$ & X-Ray Powder Diffraction Intensity Set (Quantitative Powder Diffraction Standard) & $10 \mathrm{~g}$ \\
\hline $\mathbf{6 7 5}$ & Line Position, Mica (XRD) & $7.5 \mathrm{~g}$ \\
\hline $\mathbf{6 7 6 a}$ & Alumina Powder for Quantitative Analysis by X-Ray Diffraction & $20 \mathrm{~g}$ \\
\hline $\mathbf{1 8 7 8 b}$ & Respirable Alpha Quartz (Quantitative X-Ray Powder Diffraction Standard) & $5 \mathrm{~g}$ \\
\hline $\mathbf{1 8 7 9 b}$ & Respirable Cristobalite & $5 \mathrm{~g}$ \\
\hline $\mathbf{1 9 7 6 b}$ & Instrument Response Standard for X-Ray Powder Diffraction & disc \\
\hline $\mathbf{1 9 7 9}$ & Powder Diffraction Line Profile Standard for Crystallite Size Analysis (Nano-Crystalline ZnO Powder) & $2 \times 3 \mathrm{~g}$ \\
\hline $\mathbf{1 9 9 0}$ & Single Crystal Diffractometer Alignment Standard - Ruby Sphere & 3 spheres \\
\hline $\mathbf{1 9 9 4}$ & Standard Silicon Single Crystal Wafer for Crystalline Orientation & $100-\mathrm{mm}$ wafer \\
\hline $\mathbf{1 9 9 5}$ & Standard Sapphire Single Crystal Wafer for Crystalline Orientation & 50 -mm wafer \\
\hline $\mathbf{2 0 0 0}$ & Calibration Standard for High-Resolution X-Ray Diffraction & block \\
\hline $\mathbf{2 0 1 2}$ & Calibration Standard for High-Resolution X-Ray Diffraction (200 mm Wafer) & wafer \\
\hline $\mathbf{3 6 0 0}$ & Absolute Intensity Calibration Standard for Small-Angle X-Ray Scattering & coupon \\
\hline
\end{tabular}

See Table 209.1 on the website for more information.

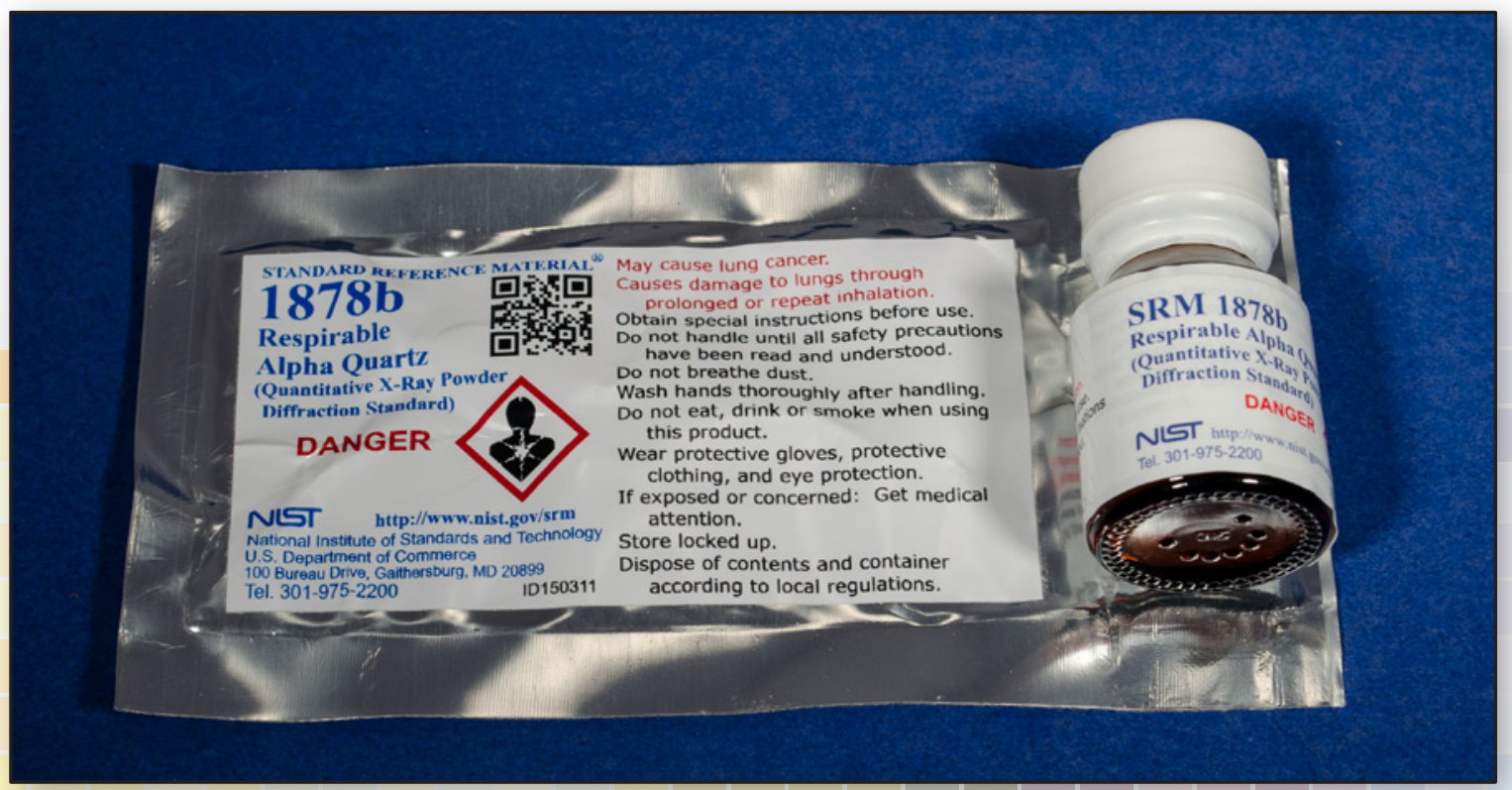




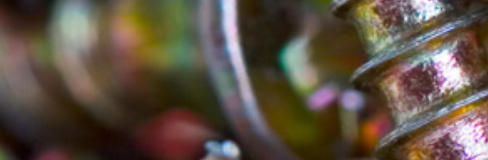

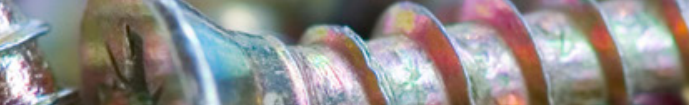
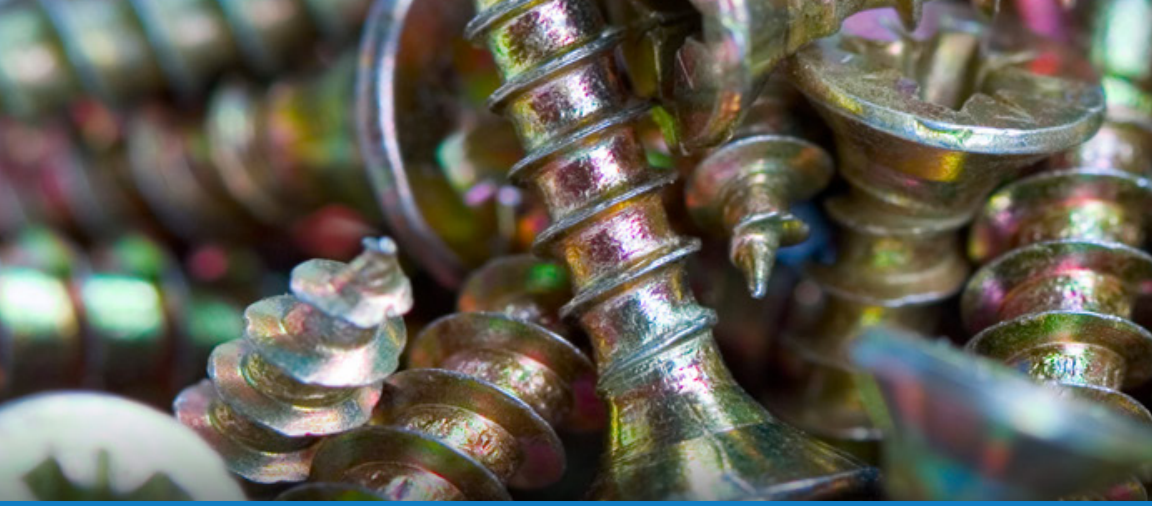

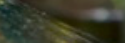
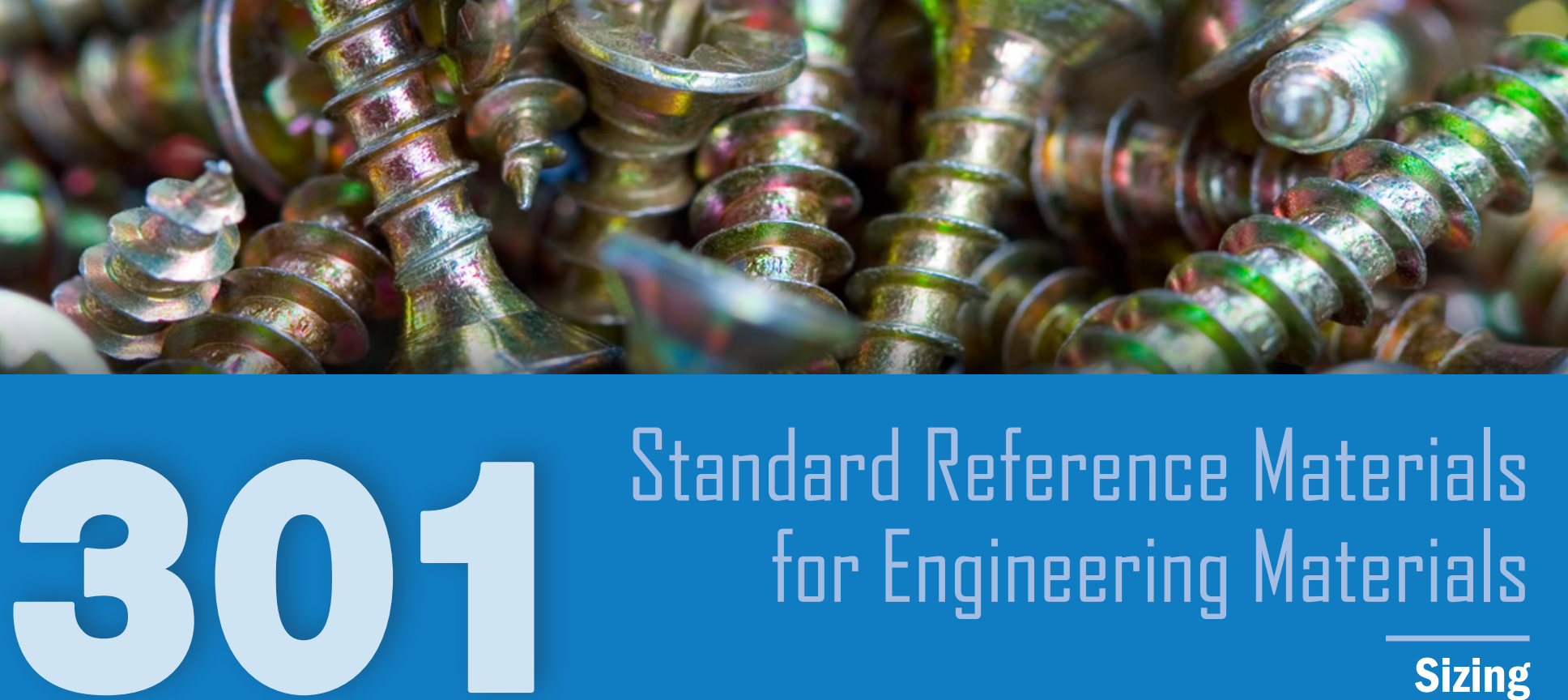

Standard Reference Materials for Engineering Materials

Sizing 


\section{Particle Size (powder and solid forms)}

These SRMs are for evaluating and calibrating specific types of particle size measuring instruments, including light scattering, electrical zone flow-through counters, optical and scanning electron microscopes, sedimentation systems, and wire cloth sieving devices.

SRMs 1003c, 1004b, 1017b, 1018b and 1019b each consist of soda-lime glass beads covering a particular size distribution (PSD) range. RM 8010 is a three bottle set of different sands (A, C and D), intended for use in sieving only, and covers the sieve size range from 30 mesh to 325 mesh.

SRM 659 consists of equiaxed silicon nitride particles measured using sedimentation. SRM 1978 consists of granular, irregular shaped zirconium oxide particles measured using sedimentation. SRM 1982 consists of spheroidal particles measured using scanning electron microscopy, laser scattering, and sieving.

SRMs 1961 is monodisperse latex particles in a water suspension produced by the National Aeronautics and Space Administration (NASA). SRM 1965 consists of two different groupings of particles mounted on a microscope slide.

RMs 8011,8012 , and 8013 are gold nanoparticles in water.

\begin{tabular}{|l|l|c|}
\hline SRM & Description & $\begin{array}{c}\text { Unit of } \\
\text { Issue }\end{array}$ \\
\hline $\mathbf{6 5 9}$ & $\begin{array}{l}\text { Particle Size Distribution Standard } \\
\text { for Sedigraph Calibration }\end{array}$ & set $(5)$ \\
\hline $\mathbf{1 0 0 3 c}$ & Glass Beads - Particle Size Distribution & $28 \mathrm{~g}$ \\
\hline $\mathbf{1 0 0 4 b}$ & Glass Beads - Particle Size Distribution & $43 \mathrm{~g}$ \\
\hline $\mathbf{1 0 1 7 b}$ & $\begin{array}{l}\text { Glass Beads - Particle Size Distribution } \\
(100 \mu \mathrm{m} \text { to } 400 \mu \mathrm{m} \text { diameter range })\end{array}$ & $70 \mathrm{~g}$ \\
\hline $\mathbf{1 0 1 8 b}$ & Glass (Particle Size $)$ & $87 \mathrm{~g}$ \\
\hline $\mathbf{1 0 1 9 b}$ & Glass (Particle Size $)$ & $200 \mathrm{~g}$ \\
\hline $\mathbf{1 0 2 1}$ & Glass ( Particle Size $)$ & $4 \mathrm{~g}$ \\
\hline $\mathbf{1 6 9 0}$ & $\begin{array}{l}\text { Polystyrene Spheres } \\
(1 \mu \mathrm{m} \text { Diameter Particle Size })\end{array}$ & $5 \mathrm{~mL}$ \\
\hline $\mathbf{1 6 9 1}$ & $\begin{array}{l}\text { Polystyrene Spheres } \\
(0.3 \mu \mathrm{m} \text { Diameter Particle Size })\end{array}$ & $5 \mathrm{~mL}$ \\
\hline $\mathbf{1 9 6 1}$ & $\begin{array}{l}\text { Polystyrene Spheres } \\
(30 \mu \mathrm{m} \text { Diameter Particle Size })\end{array}$ & $5 \mathrm{~mL}$ \\
\hline $\mathbf{1 9 6 3 a}$ & $\begin{array}{l}\text { Polystyrene Spheres } \\
(100 \text { nm Diameter Particle Size })\end{array}$ & $\begin{array}{l}\text { Polystyrene Spheres } \\
(60 \text { nm Diameter Particle Size })\end{array}$ \\
\hline $\mathbf{1 9 6 4}$ & $\begin{array}{l}\text { Microsphere Slide } \\
(10 \mu \mathrm{m} \text { Polystyrene Spheres })\end{array}$ \\
\hline $\mathbf{1 9 6 5}$ & \\
\hline
\end{tabular}

\begin{tabular}{|c|c|c|}
\hline SRM & Description & $\begin{array}{l}\text { Unit of } \\
\text { Issue }\end{array}$ \\
\hline 1978 & $\begin{array}{l}\text { Particles Size Distribution Standard } \\
\text { for Gravity Sedimentation }\end{array}$ & $5 \mathrm{~g}$ \\
\hline 1982 & $\begin{array}{l}\text { Zirconia Thermal Spray Powder - } \\
\text { Particle Size Distribution }\end{array}$ & $10 \mathrm{~g}$ \\
\hline 1984 & $\begin{array}{l}\text { Thermal Spray Powder - Particle Size } \\
\text { Distribution Tungsten Carbide/Cobalt } \\
\text { (Acicular) }\end{array}$ & $14 \mathrm{~g}$ \\
\hline 1985 & $\begin{array}{l}\text { Thermal Spray Powder - Particle Size } \\
\text { Distribution Tungsten Carbide/Cobalt } \\
\text { (Spheroidal) }\end{array}$ & $14 \mathrm{~g}$ \\
\hline 8010 & Sand for Sand Sieve Analysis & $3 \times 150 \mathrm{~g}$ \\
\hline 8011 & $\begin{array}{l}\text { Gold Nanoparticles, } \\
\text { Nominal } 10 \mathrm{~nm} \text { Diameter }\end{array}$ & $2 \times 5 \mathrm{~mL}$ \\
\hline 8012 & $\begin{array}{l}\text { Gold Nanoparticles, } \\
\text { Nominal } 30 \text { nm Diameter }\end{array}$ & $2 \times 5 \mathrm{~mL}$ \\
\hline 8013 & $\begin{array}{l}\text { Gold Nanoparticles, } \\
\text { Nominal } 60 \mathrm{~nm} \text { Diameter }\end{array}$ & $2 \times 5 \mathrm{~mL}$ \\
\hline 8988 & $\begin{array}{l}\text { Titanium Dioxide Powder - } \\
\text { Particle Size Distribution }\end{array}$ & $6 \mathrm{~g}$ \\
\hline
\end{tabular}

See Table 301.1 on the website for more information.

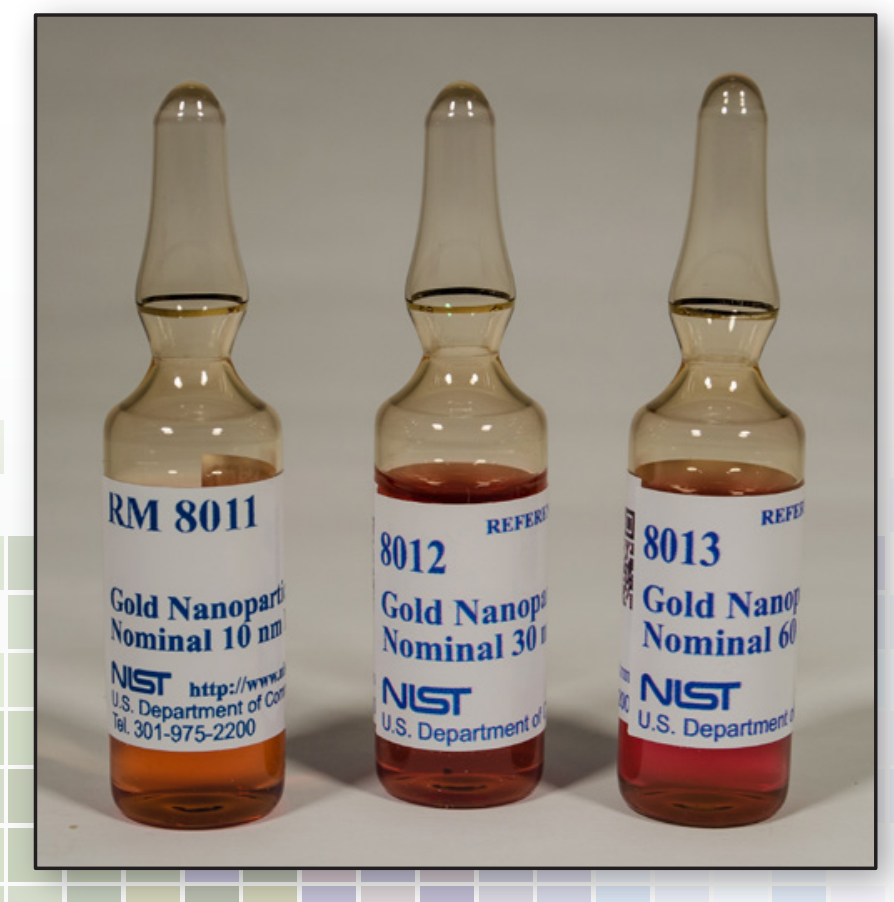




\section{Cement and Coal Fly Ash Fineness}

SRM $46 \mathrm{~h}$ is only to determine sieve residue according to ASTM C430. Each set consists of 10 sealed vials, each containing approximately $5 \mathrm{~g}$ of cement.

SRM $114 \mathrm{q}$ is for calibrating the Blaine fineness meter according to the latest issue of ASTM C204, to calibrate the Wagner turbidimeter according to ASTM C115, to determine sieve residue according to ASTM C430, and to verify procedure for particle size distribution by a laser diffraction method (no-standard method available). Each set consists of 20 sealed vials, each containing approximately $5 \mathrm{~g}$ of cement.

\begin{tabular}{|l|l|c|}
\hline SRM & Description & $\begin{array}{c}\text { Unit of } \\
\text { Issue }\end{array}$ \\
\hline $\mathbf{4 6 h}$ & Portland Cement Fineness Standard & $10 \times 5 \mathrm{~g}$ \\
\hline $\mathbf{1 1 4 q}$ & Portland Cement Fineness Standard & 20 vials \\
\hline $\mathbf{2 6 8 9}$ & Coal Fly Ash & $3 \times 10 \mathrm{~g}$ \\
\hline $\mathbf{2 6 9 0}$ & Coal Fly Ash & $3 \times 10 \mathrm{~g}$ \\
\hline $\mathbf{2 6 9 1}$ & Coal Fly Ash & $3 \times 10 \mathrm{~g}$ \\
\hline
\end{tabular}

See Table 301.2 on the website for more information.

\section{Electrophoretic Mobility, E (suspension form)}

SRM 1980 is intended for use in the calibration and evaluation of equipment used to measure electrophoretic mobility. It consists of a goethite suspension saturated with phosphate in a sodium perchlorate electrolyte solution.

\begin{tabular}{|l|l|c|}
\hline SRM & Description & $\begin{array}{c}\text { Unit of } \\
\text { Issue }\end{array}$ \\
\hline $\mathbf{1 9 8 0}$ & $\begin{array}{l}\text { Positive Electrophoretic }\left(+\mu_{\mathrm{E}}\right) \\
\text { Mobility Standard }\end{array}$ & $500 \mathrm{mg} / \mathrm{L}$ \\
\hline
\end{tabular}

See Table 301.3 on the website for more information.

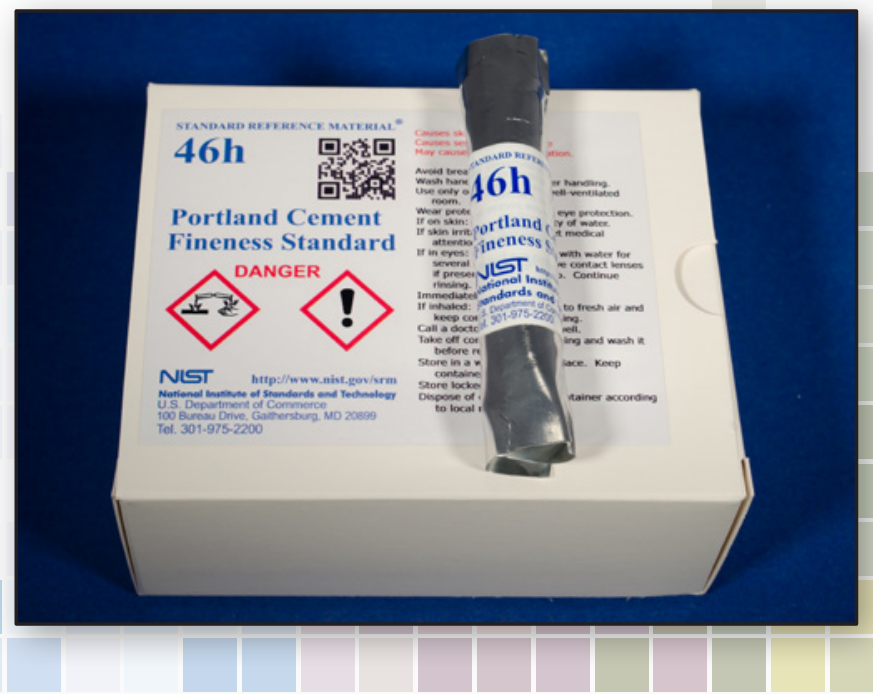

\section{Surface Area of Powders and Mercury Porosimetry Standards}

These SRMs are intended for calibrating and verifying the performance of instruments used to determine the specific surface area of powders by the Brunauer, Emmett, and Teller (BET) method or instruments that use mercury intrusion to measure the pore size and porosity of porous materials. The surface areas of SRMs 1898, 1900, 2206 and 2207 are based on both multi-point and single point analysis of the BET equation.

\begin{tabular}{|l|l|c|}
\hline SRM & Description & $\begin{array}{c}\text { Unit of } \\
\text { Issue }\end{array}$ \\
\hline $\mathbf{1 8 9 8}$ & Titanium Dioxide Nanomaterial & $15 \mathrm{~g}$ \\
\hline $\mathbf{1 9 0 0}$ & Specific Surface Area Standard & $4 \mathrm{~g}$ \\
\hline $\mathbf{1 9 1 7}$ & Mercury Porosimetry Standard & $10 \mathrm{~g}$ \\
\hline $\mathbf{2 2 0 6}$ & $\begin{array}{l}\text { Controlled Pore Glass - BET Specific } \\
\text { Surface Area (300 nm) }\end{array}$ & $5 \mathrm{~g}$ \\
\hline $\mathbf{2 2 0 7}$ & $\begin{array}{l}\text { Controlled Pore Glass - } \\
\text { BET Specific Surface Area } \\
\text { (Nominal Pore Diameter 18 nm) }\end{array}$ & $5 \mathrm{~g}$ \\
\hline $\mathbf{2 6 9 6}$ & Silica Fume & $70 \mathrm{~g}$ \\
\hline
\end{tabular}

See Table 301.4 on the website for more information.

\section{Particle Count Materials (powder and suspension forms)}

These SRM and RM materials are intended for use in calibrating the response of particle sizing instrumentation, including optical counters, in accordance with National Fluid Power Association (NFPA) and ISO standard methods (NFPA/T2.9.6 R2-1998, ISO/FDIS 11171, ISO/FDIS 12103) for determining particle contamination in oils. SRM 2806b is certified for particle concentration and projected area diameter. It consists of a polydisperse, irregularly-shaped mineral dust suspended in 5606 hydraulic fluid. RMs 8631a and 8632 are mineral test dusts of medium and ultrafine particle size and can be used to prepare suspensions in other types of oils. NOTE: The same lot of medium test dust was used to produce SRM 2806b and RM 8631a, and is a derivative of Arizona Road Dust.

\begin{tabular}{|l|l|c|}
\hline SRM & Description & $\begin{array}{c}\text { Unit of } \\
\text { Issue }\end{array}$ \\
\hline $\mathbf{2 8 0 6 b}$ & Medium Test Dust (MTD) in Hydraulic Fluid & $2 \times 400 \mathrm{~mL}$ \\
\hline $\mathbf{8 6 3 1 a}$ & Medium Test Dust (MTD) & $20 \mathrm{~g}$ \\
\hline $\mathbf{8 6 3 2}$ & Ultra Fine Test Dust (UFTD) & $20 \mathrm{~g}$ \\
\hline
\end{tabular}

See Table 301.5 on the website for more information. 


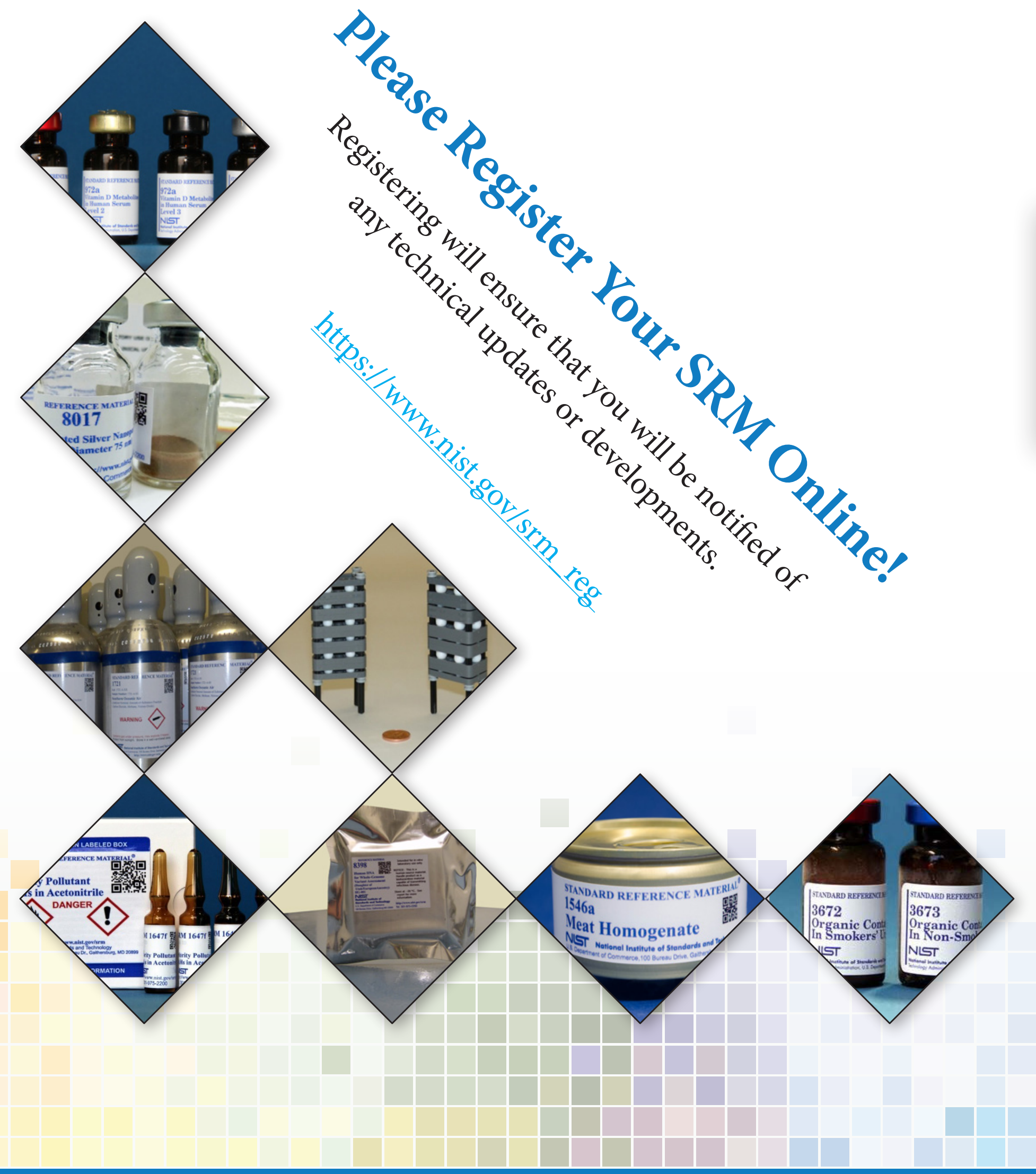

www.nist.gov/srm | Phone: 301.975.2200 | Fax: 301.948.3730 | Email: srminfo@nist.gov 84 

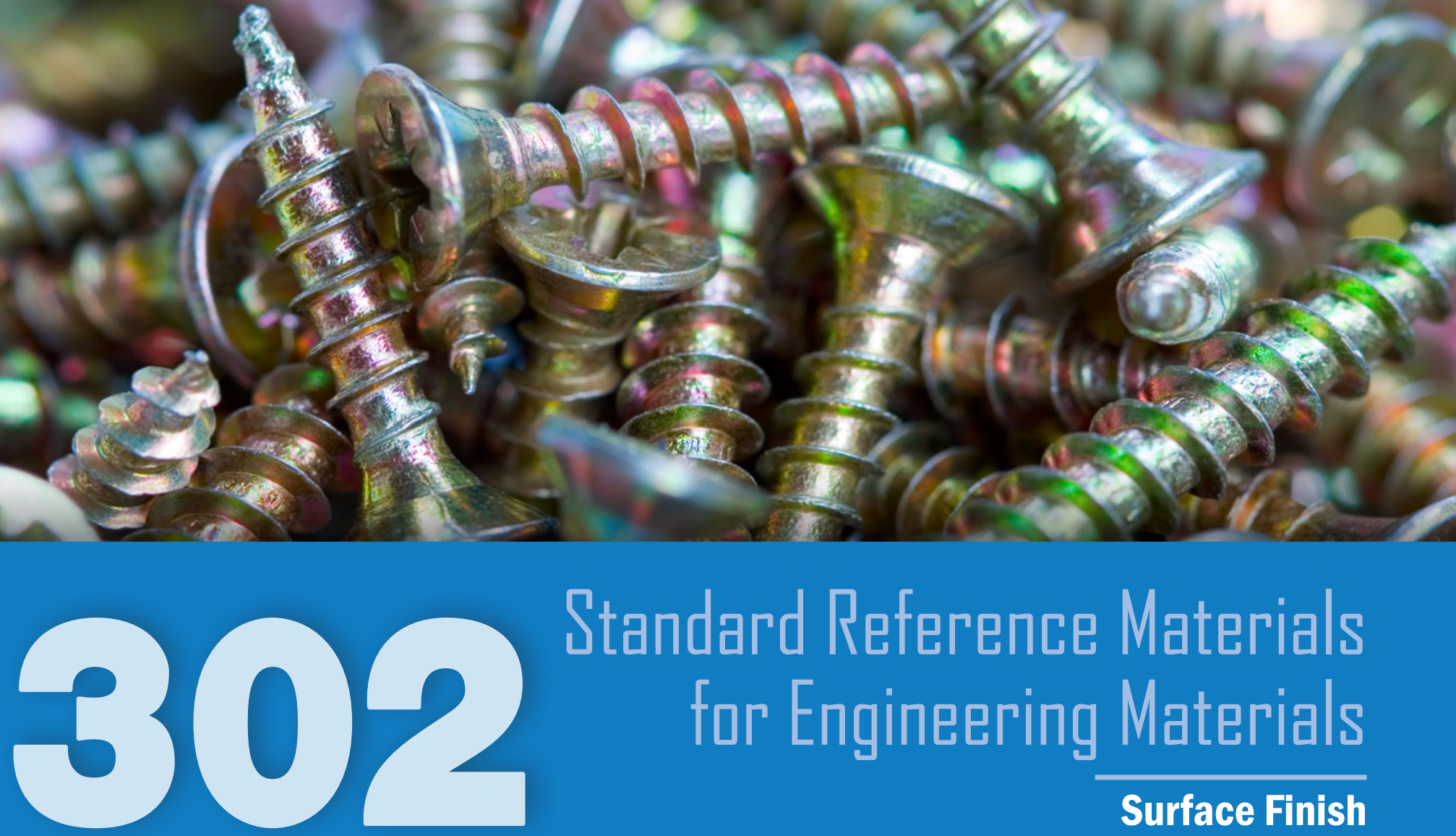


\section{Microindentation Hardness}

\section{(block form)}

These SRMs are for use in calibrating and checking the performance of microhardness testers and may be used in conjunction with ASTM E 384. SRMs 1893 through 1907 are $1.25 \mathrm{~cm} \mathrm{x} 1.25 \mathrm{~cm}$ (SRM 2798 is $1.35 \mathrm{~cm} \mathrm{x} 1.35 \mathrm{~cm}$ ) and were made by electroforming the test metal on AISI 1010 steel substrate. SRMs 2830 and 2831 are intended to meet the needs of the structural, electronic, and biomedical ceramics communities.

\begin{tabular}{|l|l|c|}
\hline SRM & Description & $\begin{array}{c}\text { Unit of } \\
\text { Issue }\end{array}$ \\
\hline $\mathbf{1 8 9 3}$ & Copper Microhardness Test Block (Knoop) & each \\
\hline $\mathbf{1 8 9 4 a}$ & Vickers Microhardness of Copper & each \\
\hline $\mathbf{1 8 9 5}$ & Nickel Microhardness Test Block (Knoop) & each \\
\hline $\mathbf{1 8 9 6}$ & Vickers Microhardness of Nickel & each \\
\hline $\mathbf{1 9 0 5}$ & Nickel Microhardness Test Block (Knoop) & each \\
\hline $\mathbf{1 9 0 6}$ & Nickel Microhardness Test Block (Knoop) & each \\
\hline $\mathbf{1 9 0 7}$ & Nickel Microhardness Test Block (Knoop) & each \\
\hline $\mathbf{1 9 0 8}$ & Vickers Microhardness of Nickel & each \\
\hline $\mathbf{1 9 0 9}$ & Vickers Microhardness of Nickel & each \\
\hline $\mathbf{2 7 9 8}$ & Vickers Microhardness of Nickel & each \\
\hline $\mathbf{2 8 2 8}$ & Knoop Microhardness of Steel & each \\
\hline $\mathbf{2 8 2 9}$ & Vickers Microhardness of Steel & each \\
\hline $\mathbf{2 8 3 0}$ & Knoop Hardness of Ceramics & each \\
\hline $\mathbf{2 8 3 1}$ & $\begin{array}{l}\text { Vickers Hardness of Ceramics } \\
\text { and Hardmetals }\end{array}$ & each \\
\hline
\end{tabular}

See Table 302.1 on the website for more information.

\section{Abrasive Wear (block form)}

This SRM is for use in the dry sand/rubber wheel abrasion test per ASTM G 65, Procedure A.

\begin{tabular}{|l|l|c|}
\hline SRM & Description & Unit Size \\
\hline $\mathbf{1 8 5 7}$ & Tool Steel for Abrasive Wear Standard & 2 blocks \\
\hline
\end{tabular}

See Table 302.2 on the website for more information.

\section{Surface Roughness (block form)}

These SRMs are for calibrating stylus instruments that measure surface roughness. These electroless-nickel coated steel blocks have a sinusoidal roughness profile machined on the top surface.

\begin{tabular}{|l|l|c|}
\hline SRM & Description & $\begin{array}{c}\text { Unit of } \\
\text { Issue }\end{array}$ \\
\hline $\mathbf{2 0 7 3 a}$ & Sinusoidal Roughness Specimen & each \\
\hline $\mathbf{2 0 7 4}$ & Sinusoidal Roughness Specimen & each \\
\hline $\mathbf{2 0 7 5}$ & Sinusoidal Roughness Specimen & each \\
\hline
\end{tabular}

See Table 302.4 on the website for more information.

\section{Rockwell Hardness (block form)}

These Standard Reference Materials (SRMs) are transfer standards intended primarily for use in the calibration and verification of the performance of Rockwell hardness equipment using the applicable Rockwell hardness $\mathrm{C}$ scale (HRC), Rockwell hardness 15N scale (HR15N), or Rockwell hardness $30 \mathrm{~N}$ scale (HR30N). Each SRM unit is a steel test block, nominally $64 \mathrm{~mm}$ in diameter and $15 \mathrm{~mm}$ thick, having a polished test surface described by a micro-engraved circle $52 \mathrm{~mm}$ in diameter. Each SRM unit is individually certified and bears a unique serial number on the edge of the block.

\begin{tabular}{|l|l|c|}
\hline SRM & Description & $\begin{array}{c}\text { Unit of } \\
\text { Issue }\end{array}$ \\
\hline $\mathbf{2 8 1 0}$ & Rockwell C Hardness - Low Range & 1 block \\
\hline $\mathbf{2 8 1 1}$ & Rockwell C Hardness - Mid Range & 1 block \\
\hline $\mathbf{2 8 1 2}$ & Rockwell C Scale Hardness - High Range & 1 block \\
\hline $\mathbf{2 8 1 6}$ & $\begin{array}{l}\text { Rockwell Hardness 15N Scale - Low Range } \\
\text { (Nominal 72 HR15N) }\end{array}$ & 1 block \\
\hline $\mathbf{2 8 1 7}$ & $\begin{array}{l}\text { Rockwell Hardness 15N Scale - Mid Range } \\
\text { (Nominal 83 HR15N) }\end{array}$ & 1 block \\
\hline $\mathbf{2 8 1 8}$ & $\begin{array}{l}\text { Rockwell Hardness 15N Scale - High Range } \\
\text { (Nominal 91 HR15N) }\end{array}$ & 1 block \\
\hline $\mathbf{2 8 1 9}$ & $\begin{array}{l}\text { Rockwell Hardness 30N Scale - Low Range } \\
\text { (Nominal 45 HR30N) }\end{array}$ & 1 block \\
\hline $\mathbf{2 8 2 0}$ & $\begin{array}{l}\text { Rockwell Hardness 30N Scale - Mid Range } \\
\text { (Nominal 64 HR30N) }\end{array}$ & 1 block \\
\hline $\mathbf{2 8 2 1}$ & $\begin{array}{l}\text { Rockwell Hardness 30N Scale - High Range } \\
\text { (Nominal 79 HR30N) }\end{array}$ & 1 block \\
\hline
\end{tabular}

See Table 302.5 on the website for more information.

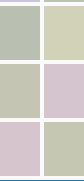




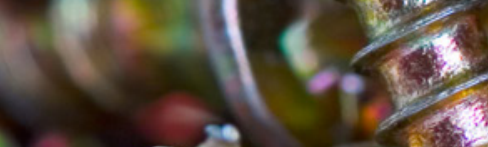

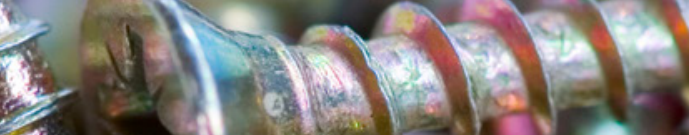
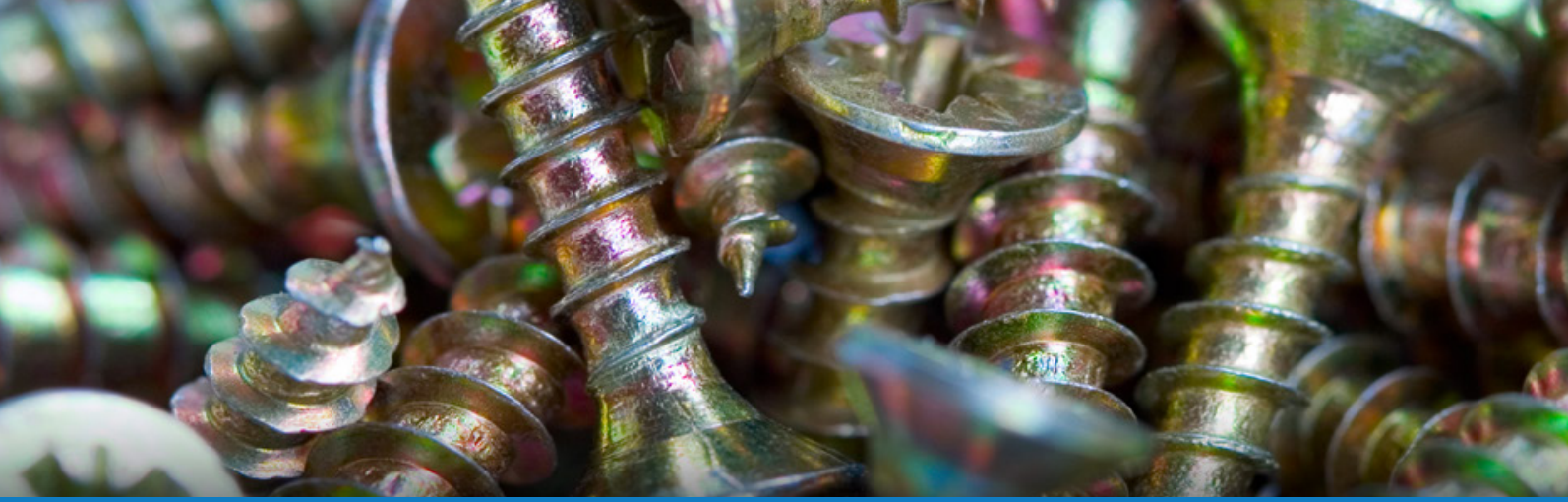

Standard Reference Materials

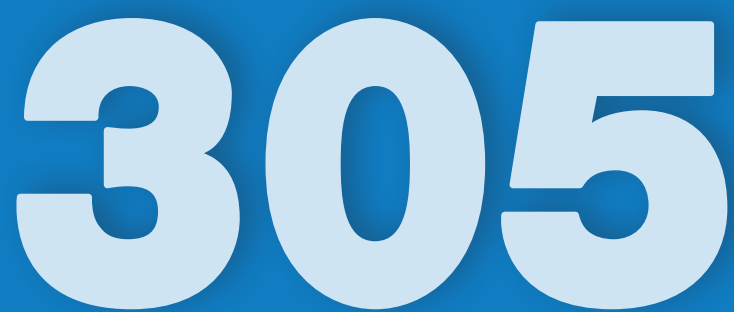
far Engineering Materials 


\section{Flooring Radiant Panel (sheet form)}

This SRM consists of three sheets of kraft paperboard. It is for checking the operation of flooring radiant panel test apparatus used to measure critical radiant flux as per ASTM E 648.

\begin{tabular}{|l|l|c|}
\hline SRM & Description & $\begin{array}{c}\text { Unit of } \\
\text { Issue }\end{array}$ \\
\hline $\mathbf{1 0 1 2}$ & Flooring Radiant Panel & set (3) \\
\hline
\end{tabular}

See Table 305.4 on the website for more information.

\section{Standard Cigarettes for Ignition \\ Strength and Ignition Resistance Testing}

SRM 1082 is intended for use by test laboratories to assess and control their testing of cigarette ignition in accordance with ASTM Standard Methods E 2187-04 (or ASTM E 2187-02b). SRM 1196 is intended for use by test laboratories to test mattresses, upholstered furniture and its components, and thermal insulation for resistance to cigarette ignition in accordance with 16 CFR 1632, 16 CFR 1634 (proposed) and 16 CFR 1209.

\begin{tabular}{|l|l|c|}
\hline SRM & Description & $\begin{array}{c}\text { Unit of } \\
\text { Issue }\end{array}$ \\
\hline $\mathbf{1 0 8 2}$ & $\begin{array}{l}\text { Cigarette Ignition Strength Standard } \\
\text { (200 cigarettes) }\end{array}$ & 1 carton \\
\hline $\mathbf{1 1 9 6}$ & $\begin{array}{l}\text { Standard Cigarette for Ignition } \\
\text { Resistance Testing (400 cigarettes) }\end{array}$ & 2 cartons \\
\hline
\end{tabular}

See Table 305.5 on the website for more information.

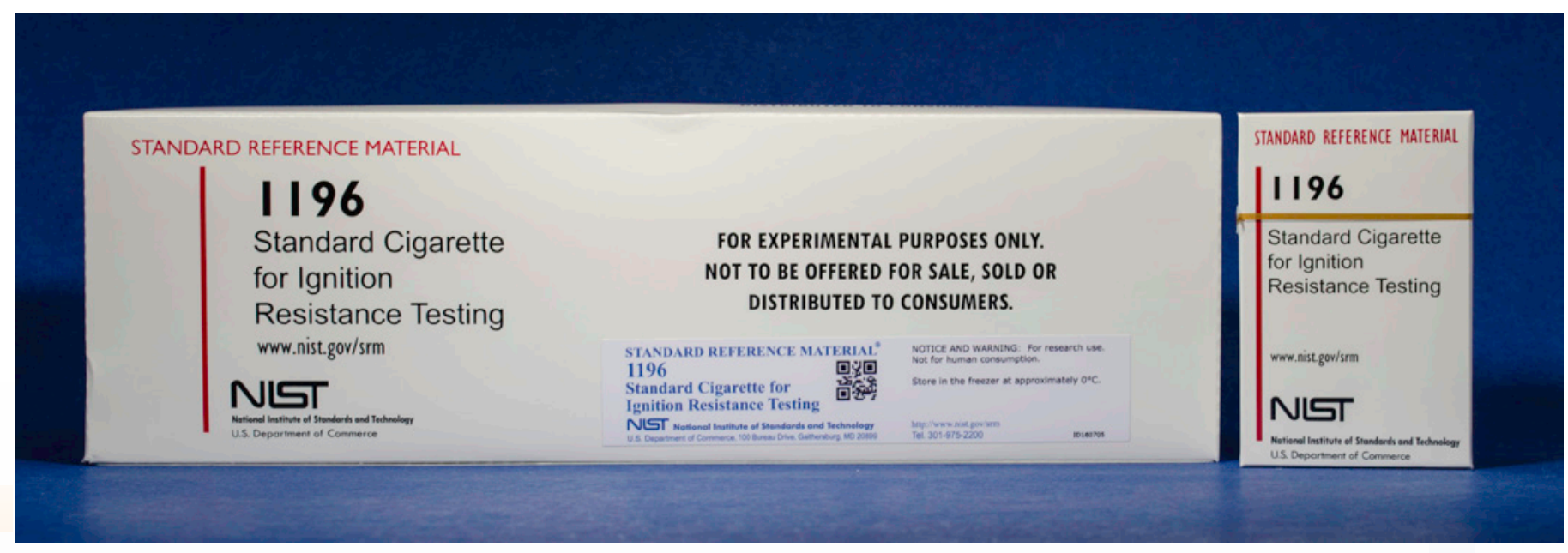



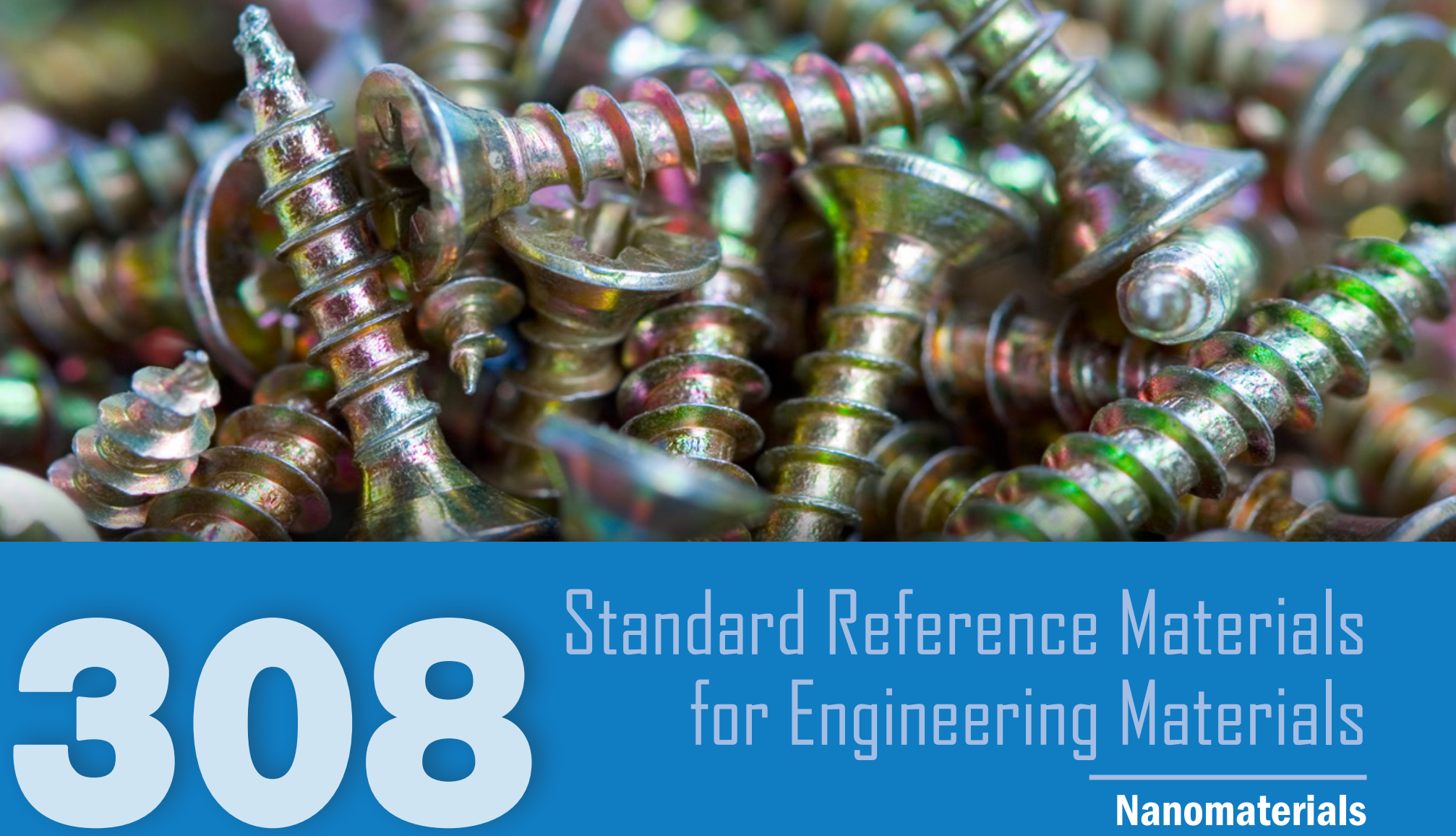


\section{Nanomaterials}

\section{(less than or equal to $100 \mathrm{~nm}$ )}

\begin{tabular}{|l|l|c|}
\hline SRM & Description & $\begin{array}{c}\text { Unit of } \\
\text { Issue }\end{array}$ \\
\hline $\mathbf{1 8 9 8}$ & Titanium Dioxide Nanomaterial & $15 \mathrm{~g}$ \\
\hline $\mathbf{1 9 6 3 a}$ & $\begin{array}{l}\text { Polystyrene Spheres } \\
\text { (Nominal 100 nm Diameter) }\end{array}$ & $5 \mathrm{~mL}$ \\
\hline $\mathbf{1 9 6 4}$ & $\begin{array}{l}\text { Polystyrene Spheres } \\
\text { (Nominal 60 nm Diameter) }\end{array}$ & $5 \mathrm{~mL}$ \\
\hline $\mathbf{2 4 8 3}$ & Single-Wall Carbon Nanotubes (Raw Soot) & $250 \mathrm{mg}$ \\
\hline $\mathbf{2 4 8 4}$ & Multiwall Carbon Nanotubes (Raw Soot) & $6 \mathrm{~g}$ \\
\hline $\mathbf{8 0 1 1}$ & $\begin{array}{l}\text { Gold Nanoparticles, } \\
\text { Nominal 10 nm Diameter }\end{array}$ & $2 \times 5 \mathrm{~mL}$ \\
\hline $\mathbf{8 0 1 2}$ & $\begin{array}{l}\text { Gold Nanoparticles, } \\
\text { Nominal 30 nm Diameter }\end{array}$ & $2 \times 5 \mathrm{~mL}$ \\
\hline $\mathbf{8 0 1 3}$ & $\begin{array}{l}\text { Gold Nanoparticles, } \\
\text { Nominal 60 nm Diameter }\end{array}$ & $2 \times 5 \mathrm{~mL}$ \\
\hline $\mathbf{8 0 1 7}$ & $\begin{array}{l}\text { Polyvinylpyrrolidone Coated Silver } \\
\text { Nanoparticles (Nominal Diameter 75 nm) }\end{array}$ & 5 vials \\
\hline $\mathbf{8 0 2 7}$ & $\begin{array}{l}\text { Silicon Nanoparticles } \\
\text { (Nominal Diameter 2 nm) }\end{array}$ & $5 \times 1.0 \mathrm{~mL}$ \\
\hline $\mathbf{8 2 8 1}$ & $\begin{array}{l}\text { Single-Wall Carbon Nanotubes (Dispersed, } \\
\text { Three Length-Resolved Populations) }\end{array}$ & $4 \times 2.5 \mathrm{~mL}$ \\
\hline
\end{tabular}

See Table 308.1 on the website for more information.

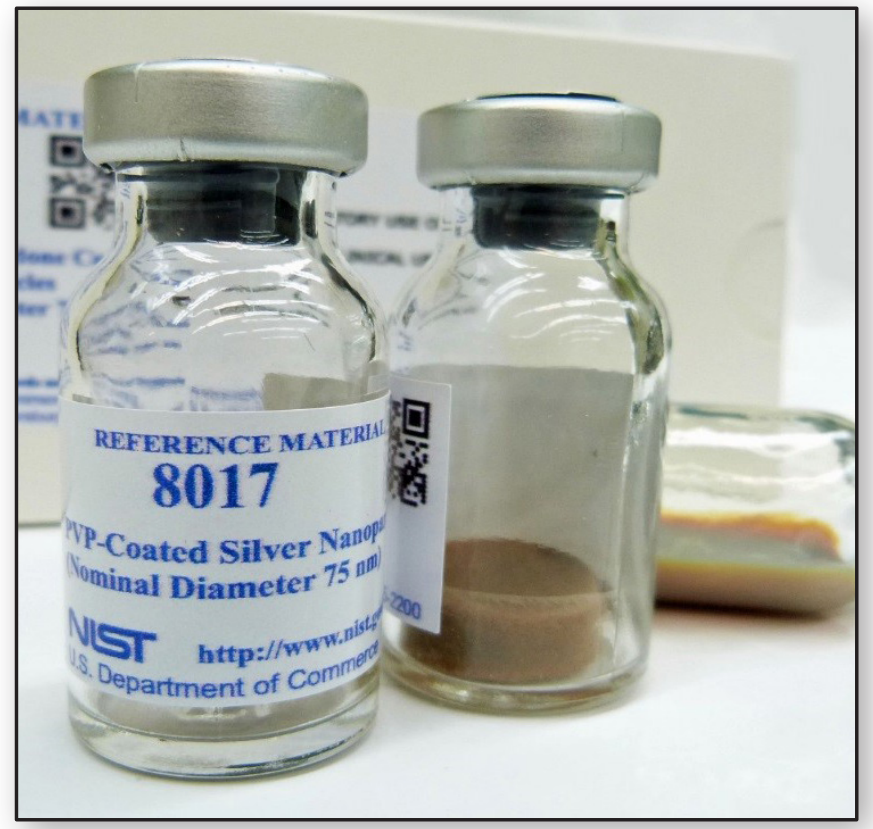



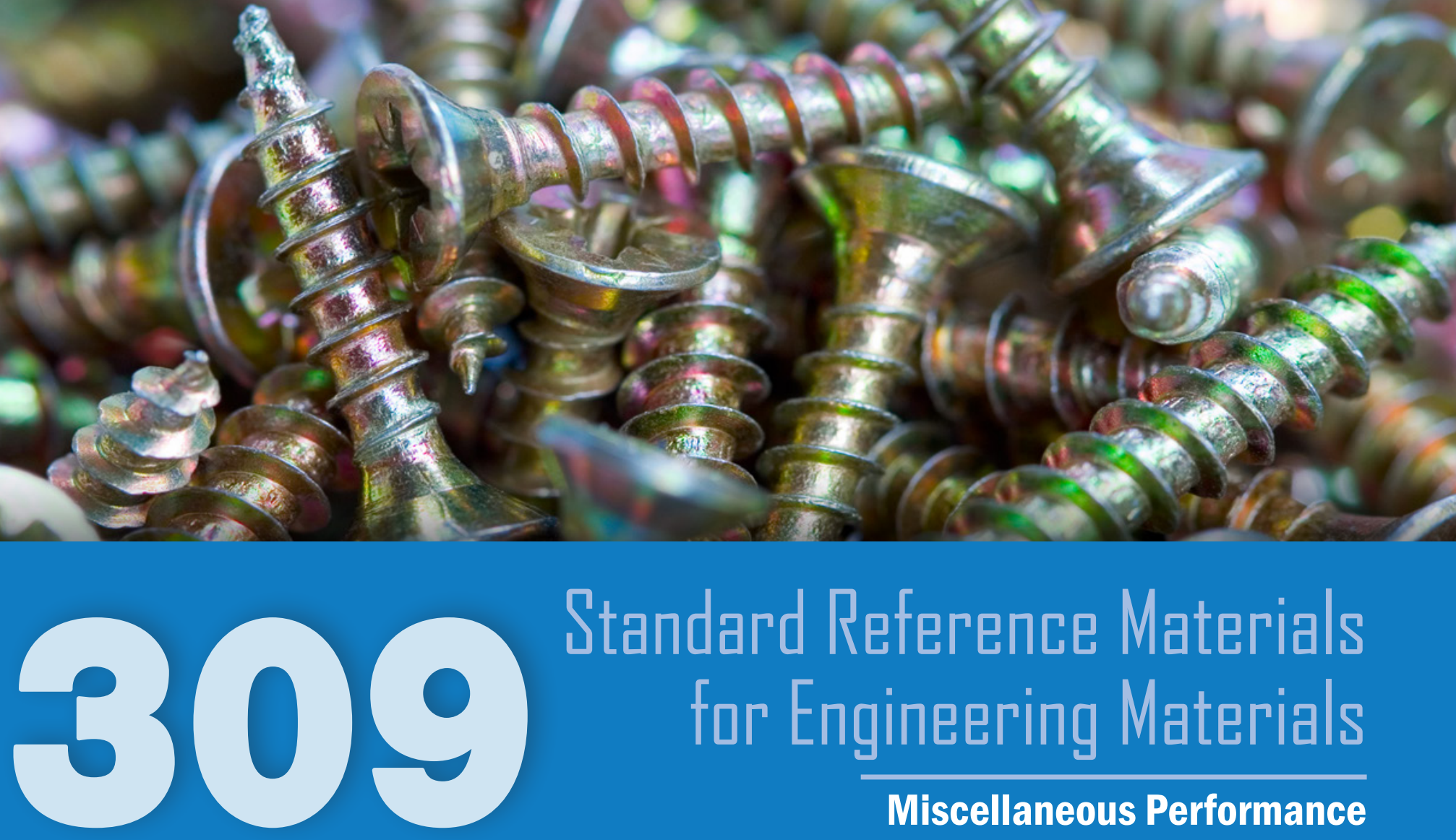


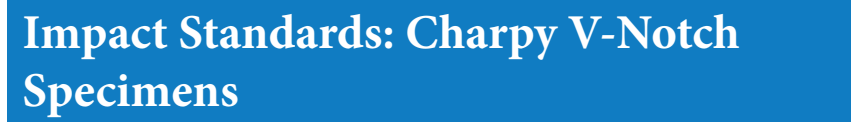

These SRMs are test specimens intended primarily for the verification of Charpy testing machines. The dimensions of these SRMs comply with the current ASTM Standard E23 and the current ISO 148-1 Standard.

SRMs 2092, 2096, and 2098 are NIST-Verification Charpy $\mathrm{V}$-notch specimens that have a post-test evaluation service and proficiency test data available with them. SRMs 2092 and 2096 are to be tested at $-40{ }^{\circ} \mathrm{C}$; SRM 2098 is to be tested at room temperature $\left(21^{\circ} \mathrm{C}\right)$. These SRMs should be tested (broken) at the same time, then returned to NIST Boulder for evaluation. An acceptable machine will produce an average value within $1.4 \mathrm{~J}$ or $5 \%$ of the certified energy value, whichever is greater.

SRMs 2093 and 2097 are Self-Verification Charpy V-notch specimens that do not have any post-test services available with them. These SRMs provide a lower cost option for the Self-Service user. SRMs 2093 and 2097 are to be tested at $-40{ }^{\circ} \mathrm{C}$. These SRMs are not returned to NIST Boulder for evaluation.

SRMs 2112 and 2113 are NIST-Verification Charpy V-notch specimens that are certified for absorbed energy at $-40{ }^{\circ} \mathrm{C}$ and room temperature and for maximum force at room temperature. These SRMs provide a means to verify the performance of both the energy and force scales of an instrumented

Charpy impact machine at room temperature $\left(21^{\circ} \mathrm{C}\right)$. They can also be used to verify just the energy scale of a machine at $-40^{\circ} \mathrm{C}$, interchangeably with SRMs 2092 and 2096. An acceptable machine will produce an average value within $1.4 \mathrm{~J}$ or $5 \%$ of the certified energy value, whichever is greater. Currently, specific requirements are not available to verify the performance of the force scale for a Charpy test machine.

SRMs 2216, 2218, and 2219 are intended for the verification of maximum force and absorbed energy values measured at room temperature using a small-scale Charpy impact machine, in accordance with the current standards ASTM E2248 or ISO 14556. Each SRM unit consists of a set of three KLST-type specimens needed to perform a single verification.

\begin{tabular}{|c|c|c|}
\hline SRM & Description & $\begin{array}{l}\text { Unit of } \\
\text { Issue }\end{array}$ \\
\hline 2092 & $\begin{array}{l}\text { Low-Energy Charpy V-Notch Impact } \\
\text { Specimens (NIST-Verification, 8-mm } \\
\text { Striker) }\end{array}$ & set \\
\hline 2093 & $\begin{array}{l}\text { Low-Energy Charpy V-Notch Impact } \\
\text { Specimens (Self-Verification, 8-mm } \\
\text { Striker) }\end{array}$ & set \\
\hline 2096 & $\begin{array}{l}\text { High-Energy Charpy V-Notch Impact } \\
\text { Specimens (NIST-Verification, 8-mm } \\
\text { Striker) }\end{array}$ & set \\
\hline 2097 & $\begin{array}{l}\text { High-Energy Charpy V-Notch Impact } \\
\text { Specimens (Self-Verification, 8-mm } \\
\text { Striker) }\end{array}$ & set \\
\hline 2098 & $\begin{array}{l}\text { Super High-Energy Charpy V-Notch } \\
\text { Impact Specimen (NIST-Verification) }\end{array}$ & set \\
\hline 2112 & $\begin{array}{l}\text { Dynamic Impact Force Verific Specimens } \\
\text { (Self-Verification, } 8 \text {-mm Striker, } 24 \mathrm{kN} \\
\text { nominal) }\end{array}$ & set \\
\hline 2113 & $\begin{array}{l}\text { Dynamic Impact Force Verification } \\
\text { Specimens (Self-Verification, 8-mm } \\
\text { Striker, } 33 \mathrm{kN} \text { nominal) }\end{array}$ & set \\
\hline 2197 & $\begin{array}{l}\text { Low-Energy Charpy V-Notch Specimens } \\
\text { (Self-Verification, 2-mm Striker) }\end{array}$ & set \\
\hline 2198 & $\begin{array}{l}\text { High-Energy Charpy V-Notch Specimens } \\
\text { (Self-Verification, 2-mm Striker) }\end{array}$ & set \\
\hline 2216 & $\begin{array}{l}\text { Miniaturized Low Energy Charpy, } \\
\text { V-Notch KLST Impact Specimen }\end{array}$ & set \\
\hline 2218 & $\begin{array}{l}\text { Miniaturized Hi Energy Charpy, } \\
\text { V-Notch KLST Impact Specimen }\end{array}$ & set \\
\hline 2219 & $\begin{array}{l}\text { Miniaturized Super High Energy, } \\
\text { Charpy V-Notch KLST Impact Specimen }\end{array}$ & set \\
\hline
\end{tabular}

See Table 309.1 on the website for more information.

Full-size (standard) Charpy specimen

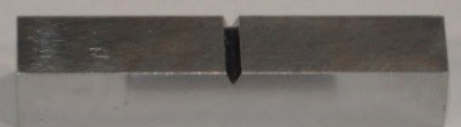

Miniaturized (KLST-type) Charpy specimen

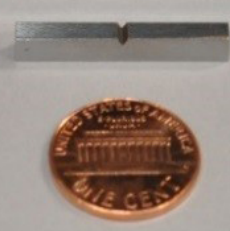




\section{Tape Adhesion Testing (sheet form)}

This SRM is intended as a uniform source of linerboard for use with ASTM $>$ Standards D 2860 Standard Test Method for Adhesion of Pressure-Sensitive Tape to Fiberboard at $90^{\circ}$ Angle and Constant Stress, D 3654 Standard Test Method for Holding Power of Pressure-Sensitive Tapes, and D 3889 Standard Method for Adherence to Linerboard of PressureSensitive Tapes at Low Temperature.

\begin{tabular}{|l|l|c|}
\hline SRM & Description & $\begin{array}{c}\text { Unit of } \\
\text { Issue }\end{array}$ \\
\hline 1810a & Linerboard & 50 each \\
\hline
\end{tabular}

See Table 309.4 on the website for more information.

\section{Bleached Kraft Pulps (sheet form)}

RM 8495 Northern Softwood Bleached Kraft Pulp and RM 8496 Eucalyptus Hardwood Bleached Kraft Pulp are intended primarily for use in fundamental studies on the physical properties of fibers and paper sheets. The materials selected for these two RMs are bleached dried lap pulp, each from a single lot of a standard commercial production run. The materials were selected because of their differing fiber size, differing papermaking properties, and similarity to commercially available materials.

RMs 8495 and 8496 were developed and prepared with input and support from the Pulp Material Research Committee (PMRC), a subcommittee of the Fundamental Research Committee.

\begin{tabular}{|l|l|c|}
\hline SRM & Description & $\begin{array}{c}\text { Unit of } \\
\text { Issue }\end{array}$ \\
\hline $\mathbf{8 4 9 5}$ & Northern Softwood & 10 sheets \\
\hline $\mathbf{8 4 9 6}$ & Eucalyptus Hardwood & 10 sheets \\
\hline
\end{tabular}

See Table 309.5 on the website for more information.

\section{Healthcare Equipment Standards}

\begin{tabular}{|l|l|c|}
\hline SRM & Description & $\begin{array}{c}\text { Unit of } \\
\text { Issue }\end{array}$ \\
\hline $\mathbf{2 0 8 7}$ & $\begin{array}{l}\text { Dimensional Standard for Medical } \\
\text { Computed Tomography }\end{array}$ & each \\
\hline $\mathbf{2 0 8 8}$ & $\begin{array}{l}\text { Density Standard for Medical } \\
\text { Computed Tomography }\end{array}$ & $\begin{array}{c}\text { five foam } \\
\text { blocks }\end{array}$ \\
\hline
\end{tabular}

See Table 309.10 on the website for more information.

\section{Fracture Toughness of Ceramics}

SRMs 2100a and 2100b Fracture Toughness of Ceramic are intended for verification of fracture toughness testing procedures and may be used in conjunction with ASTM Standard Test Method ASTM C1421-99 "Standard Test Methods for Fracture Toughness of Advanced Ceramics." A unit of SRMs 2100a or 2100b consists of five hot-pressed silicon nitride flexure specimens. Each specimen is $3 \mathrm{~mm}$ $\mathrm{x} 4 \mathrm{~mm}$ x (45 to 47 ) $\mathrm{mm}$. The SRM may be used with any fracture toughness test method, but is optimized for beam bending test configurations.

\begin{tabular}{|l|l|c|}
\hline SRM & Description & $\begin{array}{c}\text { Unit of } \\
\text { Issue }\end{array}$ \\
\hline 2100a & Fracture Toughness of Ceramic & 5 bars \\
\hline 2100b & Fracture Toughness of Ceramic & 5 bars \\
\hline
\end{tabular}

See Table 309.7 on the website for more information.

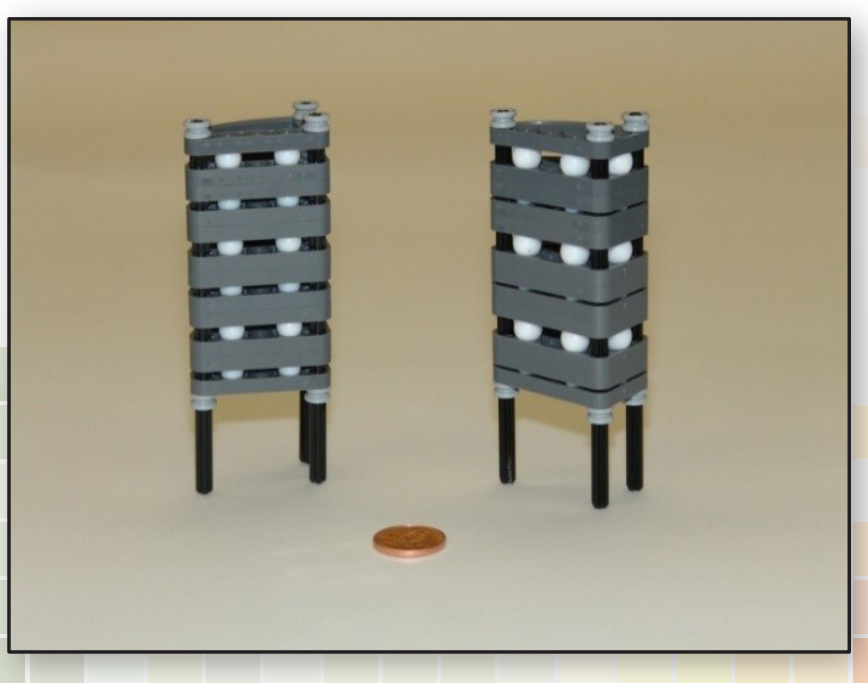

SRM 2087 Dimensional Standard for Medical Computed Topography 


\section{Magnetic Moment}

These Standard Reference Materials are intended for use in the calibration of magnetometers (such as vibrating sample magnetometers) that are used in the measurement of magnetic properties of materials.

\begin{tabular}{|l|l|c|}
\hline SRM & Description & $\begin{array}{c}\text { Unit of } \\
\text { Issue }\end{array}$ \\
\hline 762 & Magnetic Moment Standard - Nickel Disk & $6 \mathrm{~mm}$ \\
\hline 764a & $\begin{array}{l}\text { Magnetic Susceptibility Standard - } \\
\text { Platinum Cylinder }\end{array}$ & $\begin{array}{c}3 \mathrm{~mm} \mathrm{x} \\
3.42 \mathrm{~mm}\end{array}$ \\
\hline 772a & Magnetic Moment Standard - Nickel Sphere & each \\
\hline
\end{tabular}

See Table 309.8 on the website for more information.

\section{Standard Bullet and Cartridge Case}

\begin{tabular}{|l|l|c|}
\hline SRM & Description & $\begin{array}{c}\text { Unit of } \\
\text { Issue }\end{array}$ \\
\hline $\mathbf{2 4 6 0}$ & Standard Bullet & each \\
\hline $\mathbf{2 4 6 1}$ & Standard Cartridge Case & each \\
\hline
\end{tabular}

See Table 309.11 on the website for more information.

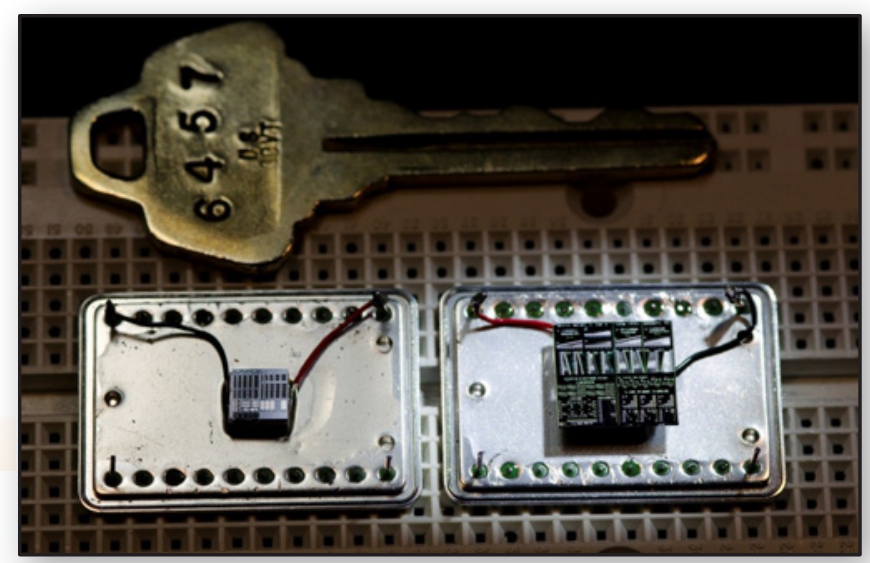

RM 8096 - CMOS MEMS 5-in-1 Test Chip

\section{Microelectromechanical Systems (MEMS)}

The MEMS 5-in-1 RM is a single test chip with test structures for the measurement of dimensional and material properties with the use of five documentary standard test methods (from which its name is derived). To validate the use of the test methods, companies can compare their measurements with NIST measurements on the same test structures. The MEMS Calculator (https://srdata.nist.gov/ gateway/ with the keyword "MEMS Calculator") can be used for the calculations.

The five test methods are for measuring Young's modulus, residual strain, strain gradient, step height, and in-plane length. Eight properties are reported; the five mentioned plus residual stress, stress gradient, and beam thickness. Residual stress and stress gradient are obtained from calculations given in the Young's modulus test method. Beam thickness is obtained using the step height test method (as described in NIST SP 260-177). Therefore, five test methods are used to obtain the reported eight properties.

The instruments used for the MEMS 5-in-1 measurements are:

- an optical vibrometer, stroboscopic interferometer, or comparable instrument for the measurement of Young's modulus, and

- an interferometric microscope and/or stylus profilometer or comparable instrument(s) for the measurement of residual strain, strain gradient, step height, in-plane length, and thickness.

There are two types of chips (RM 8096 and RM 8097). RM 8096 was fabricated on a multi-user $1.5 \mu \mathrm{m}$ complementary metal oxide semiconductor (CMOS) process followed by a bulkmicromachining etch. The supply of RM 8096 is limited.

RM 8097 was fabricated using a polysilicon multi user surface micromachining MEMS process with a backside etch.

Additional information is available on the website.

Email mems-support@nist.gov for further assistance.

\begin{tabular}{|l|l|c|}
\hline SRM & Description & $\begin{array}{c}\text { Unit of } \\
\text { Issue }\end{array}$ \\
\hline $\mathbf{8 0 9 6}$ & CMOS MEMS 5-in-1 Test Chip & $\begin{array}{c}1 \text { computer } \\
\text { chip }\end{array}$ \\
\hline $\mathbf{8 0 9 7}$ & MEMS 5-in-1 Test Chip & $\begin{array}{c}1 \text { computer } \\
\text { chip }\end{array}$ \\
\hline
\end{tabular}

See Table 309.12 on the website for more information. 
$1 \mathrm{~d}$

41

$5 \mathrm{~m}$

$6 \mathrm{~g}$

$8 \mathrm{k}$

$12 \mathrm{~h}$

$13 \mathrm{~g}$

$14 \mathrm{~g}$

$16 \mathrm{f}$

$17 f$

18

$19 \mathrm{~h}$

$20 \mathrm{~g}$

$23 \mathrm{c}$

25d

$30 \mathrm{f}$

$32 \mathrm{e}$

$33 \mathrm{e}$

$36 \mathrm{~b}$

$39 j$

$45 \mathrm{~d}$

$46 \mathrm{~h}$

$49 \mathrm{e}$

$50 \mathrm{c}$

$53 \mathrm{e}$

$54 d$

$57 \mathrm{~b}$

$58 \mathrm{a}$

$59 a$

$64 \mathrm{c}$

$68 \mathrm{c}$

$69 \mathrm{~b}$

$70 \mathrm{~b}$

$72 \mathrm{~g}$

$76 a$

$77 a$

$78 \mathrm{a}$

$79 a$

$80 a$

$81 a$

$82 \mathrm{~b}$

$84 \mathrm{~L}$

$87 a$

$88 \mathrm{~b}$

89

90

92

$93 a$

$94 \mathrm{c}$

95

$97 \mathrm{~b}$

$98 \mathrm{~b}$

$99 \mathrm{~b}$

100b

$101 \mathrm{~g}$

$107 \mathrm{c}$

$114 q$

$115 a$

$120 \mathrm{c}$

$122 \mathrm{i}$

$123 \mathrm{c}$

$125 \mathrm{~b}$

$126 \mathrm{c}$
Descriptor

Limestone, Argillaceous......................................................... 46

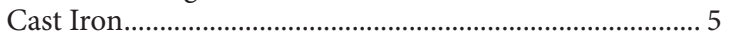

Cast Iron......................................................................... 5

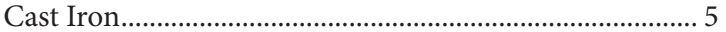

Bessemer Steel (Simulated), $0.1 \%$ Carbon............................ 2

Basic Open-Hearth Steel, 0.4 \% Carbon .............................. 2

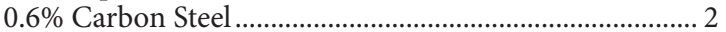

Carbon Steel (AISI 1078) ....................................................... 2

Basic Open- Hearth Steel, 1 \% carbon .................................. 2

Sucrose Optical Rotation .............................................. 14,66

Cr-10 Ni Steel (AISI 304L) (powder form).......................... 4

Basic Electric Steel, 0.2 \% Carbon ....................................... 2

AISI 1045 Steel .................................................................... 2

Stainless Steel, Cr-Ni-Nb (AISI 348) ................................... 4

Manganese Ore................................................................ 46

Cr-V Steel (SAE 6150) ......................................................... 2

Nickel-Chromium Steel (SAE 3140) ………........................ 2

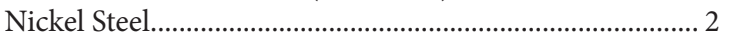

Chromim-Molybdenum Steel .............................................. 2

Benzoic Acid (Calorimetric Standard) ................................ 62

Copper Secondary Freezing Point ....................................... 63

Portland Cement Fineness Standard ................................. 83

Lead Secondary Freezing Point Standard ......................... 63

Tungsten-Chromium-Vanadium Steel................................ 4

Lead-Base Bearing Metal (84Pb-10Sb-6Sn) ...................... 9

Bearing Metal (Tin Base) ................................................... 10

Silicon Metal ........................................................................ 4

Ferrosilicon (73 \% Si Regular Grade)................................. 4

Ferrosilicon ............................................................................. 4

Ferrochromium, High Carbon............................................. 4

High-Carbon Ferromanganese ............................................ 4

Bauxite (Arkansas)................................................................ 46

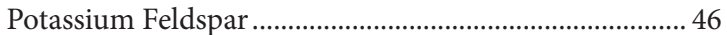

Low Alloy Steel (AISI 4130) .................................................. 2

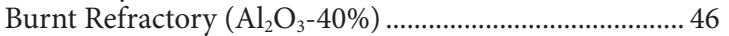

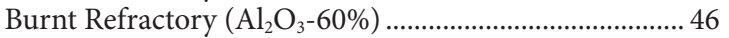

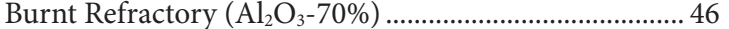

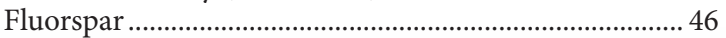

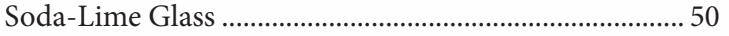

Glass Sand ..................................................................4 46, 50

Nickel-Chromium Cast Iron ................................................. 5

Potassium Hydrogen Phthalate ............................................ 14

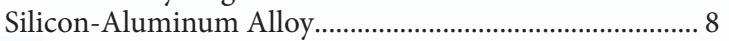

Dolomitic Limestone ............................................................ 46

Glass, Lead Barium .............................................................. 50

Ferrophosphorus............................................................. 4

Soda-Lime Glass (Low Boron).......................................... 50

Borosilicate Glass ............................................................... 50

Zinc-Base Alloy (Die Casting) ............................................. 10

1-Nitropyrene in Methylene Chloride ............................. 38

Flint Clay...

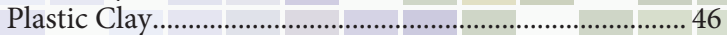

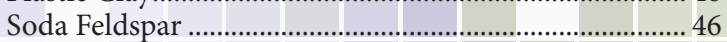

Manganese Steel .................................................................... 2

Stainless Steel (AISI 304L) (powder form) ........................ 4

Cast Iron (Ni-Cr-Mo)...

Portland Cement Fineness Standard ................................. 83

Copper-Nickel-Chromium Cast Iron ……….......................... 5

Phosphate Rock (Florida)......

Cast Iron.

Stainless Steel, Cr-Ni-Nb (AISI 348)

LA Steel, High Silicon.

High-Nickel Steel (36 \% Ni).
SRM

$127 \mathrm{~b}$

$129 \mathrm{c}$

$131 \mathrm{~h}$

$132 \mathrm{~b}$

$133 \mathrm{~b}$

$134 \mathrm{a}$

$136 f$

$139 \mathrm{~b}$

$141 \mathrm{~d}$

$143 \mathrm{~d}$

148

$152 \mathrm{a}$

$154 \mathrm{c}$

155

$158 \mathrm{a}$

$160 \mathrm{~b}$

163

$165 \mathrm{a}$

$166 \mathrm{c}$

$173 \mathrm{c}$

178

179

180

181

182

183

$185 \mathrm{i}$

$186 \mathrm{~g}$

$187 \mathrm{e}$

188

189 c

$191 d$

193

$194 \mathrm{a}$

195

196

198

199

$200 \mathrm{~b}$

$211 \mathrm{~d}$

277

278

291

293

$330 \mathrm{a}$

$331 \mathrm{a}$

$333 \mathrm{a}$

334

339

341

$342 \mathrm{a}$

$343 \mathrm{a}$

344

$345 \mathrm{~b}$

$346 \mathrm{a}$

$349 \mathrm{a}$

$350 \mathrm{c}$

$351 \mathrm{a}$
Descriptor

Page \#

Solder $(40 \mathrm{Sn}-60 \mathrm{~Pb})$......................................................... 9

LA Steel, High Sulfur (SAE 112) ......................................... 2

Refined Cast Iron ................................................................ 2

Tool Steel (AISI M2) .............................................................. 4

Chromium-Molybdenum Steel.................................................. 4

Molybdenum-Tungsten-Chromium-Vanadium Steel ..... 4 Potassium Dichromate,

(Oxidimetric Standard) ...................................................... 14

Chromium-Nickel-Molybdenum Steel................................ 2

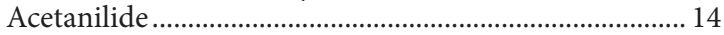

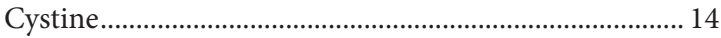

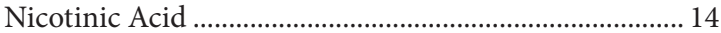

Basic Open-Hearth Steel 0.5 \% Carbon

(Tin Bearing)...

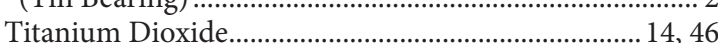

Chromium-Tungsten Steel .................................................. 2

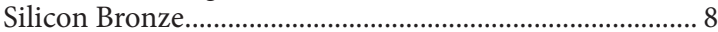

Stainless Steel (Cr 18-Ni 12-Mo 2) (AISI 316)................... 4

Chromium Steel ...................................................................... 2

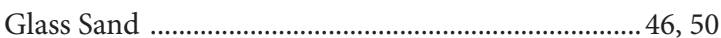

Stainless Steel, Low-Carbon (AISI 316L)............................ 4

Titanium Alloy (6Al-4V) ................................................... 10

0.4C Basic Oxygen Furnace Steel......................................... 2

LA Steel, High Silicon........................................................ 2

Fluorspar, High Grade............................................................... 46

Lithium Ore (Spodumene) ................................................. 46

Lithium Ore (Petalite) ......................................................... 46

Lithium Ore (Lepidolite) ..................................................... 46

Potassium Hydrogen Phthalate ........................................... 58

Disodium Hydrogen Phosphate (186-II-g)

Sodium Tetraborate (Borax), $\mathrm{pH}$....................................... 58

Potassium Hydrogen Tartrate............................................. 58

Potassium Tetroxalate Dihydrate ...................................... 58

pH Standard

Sodium Bicarbonate (191d-I)

Sodium Carbonate (191d-II)........................................... 58

Potassium Nitrate.................................................................. 43

Ammonium Dihydrogen Phosphate................................... 43

Ferrosilicon (75 \% Si-HP Grade) ........................................... 4

Ferrochromium, (Low-Carbon) .......................................... 4

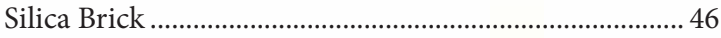

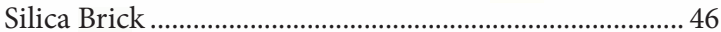

Potassium Dihydrogen Phosphate, (KH2PO4) ............... 43

Toluene Liquid Density - Extended Range....................... 78

Tungsten Concentrate ........................................................ 46

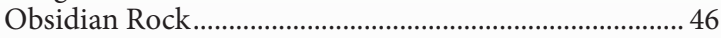

Cr-Mo Steel (ASTM A-213) ................................................ 2

Cr-Ni-Mo (AISI 8620)......................................................... 2

Copper Ore Mill Heads............................................................ 46

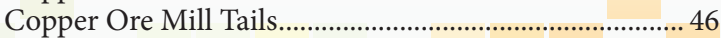

Molybdenum Sulfide Concentrate...................................... 46

Gray Cast Iron ....................................................................... 5

17 Chromium-9 Nickel-0.2 Selenium Steel....................... 4

Ductile Cast Iron........................................................................ 5

Nodular Cast Iron ................................................................... 5

Stainless Steel (AISI 431) ................................................... 4

15 Chromium-7 Nickel Steel

(Mo Precipitation Hardening).

Fe-Cr-Ni Alloy UNS J92180 (chip form)

Valve Steel

Waspaloy.....

Benzoic Acid (Acidimetric)

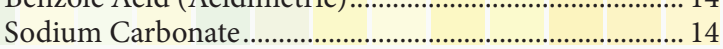


Descriptor

Page \#

Zirconium (Sn-Fe-Cr) Alloy .............................................. 10

AISI 4340 Steel ..................................................................... 2

Chromium-Vanadium Steel (Modified) ............................... 2

LA Steel, High C (Modified) .................................................... 2

Carbon Steel (AISI 1211) ........................................................ 2

Unalloyed Copper - Cu VI ................................................... 9

Unalloyed Copper - Cu VII .................................................... 9

Molybdenum Oxide Concentrate ......................................... 46

Unalloyed Copper XI (chips) ............................................... 9

Unalloyed Copper IV (solid)................................................. 9

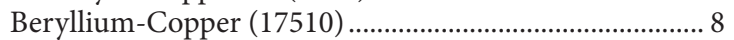

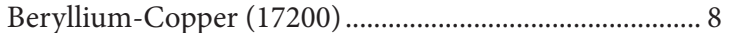

Beryllium-Copper Alloy ..................................................... 8

Tungsten $20 \%$ - Molybdenum Alloy

Electron Microprobe Standard.......................................... 12

Gold-Silver Wires for Microprobe Analysis..................... 12

Gold-Copper Wires for Microprobe Analysis ................ 12

Unalloyed Copper I (solid) ................................................. 9

Unalloyed Copper II (solid) ................................................... 9

Unalloyed Copper V (solid) .................................................... 9

Unalloyed Copper VI (solid)............................................... 9

Unalloyed Copper - Cu VII ................................................... 9

Bauxite, Australian-Darling Range...................................... 46

Potassium Feldspar ............................................................. 46

Trace Elements in Glass ...................................................... 50

Trace Elements in Glass ...................................................... 50

Trace Elements in Glass ........................................ 50

Trace Elements in Glass ...................................................... 50

Trace Elements in Glass .................................................... 50

Trace Elements in Glass ....................................................... 50

Trace Elements in Glass ..................................................... 50

Soda Lime, Flat..................................................... 50

Soda-Lime-Silica Glass......................................................... 78

Lead-Silica Glass for dc Volume Resistivity ..................... 78

Spectrographic Zinc-Base Die-Casting Alloy A .............. 10

Spectrographic Zinc-Base Die-Casting Alloy B.............. 10

Spectrographic Zinc-Base Die-Casting Alloy C ............. 10

Spectrographic Zinc-Base Die-Casting Alloy D .............. 10

Spectrographic Zinc-Base Die-Casting Alloy E............... 10

Spectrographic Zinc-Base Die-Casting Alloy F.............. 10

Spectrographic Zinc Spelter (Modified) ............................ 10

Portland Cement................................................................ 52

Portland Cement ................................................................ 52

Portland Cement (Blended with Slag) .............................. 52

Shape Standard for Powder Diffraction

(Silicon Powder). 80

Spectroscopic Titanium-Base Standards

Titanium Alloy, 8 Mn (A) ............................................... 10

Spectroscopic Titanium-Base Standards

Titanium Alloy, $8 \mathrm{Mn}$ (B) ...

Spectroscopic Titanium-Base Standards

Titanium Alloy, $8 \mathrm{Mn}(\mathrm{C})$.................................................. 10

Titanium Alloy, Al-Mo-Sn-Zr........................................... 10

Titanium-Base Alloy (5Al-2Sn-2Zr-4Cr-4Mo) .............. 10

Titanium-Base Alloy (15V-3Al-3Cr-3Sn) .......................... 10

Unalloyed Titanium A..................................................... 10

Titanium Alloy, Al-V ........................................................ 10

Silicon Nitride for Quantitative Analysis

by Powder Diffraction....

Particle Size Distribution Standard for

Sedigraph Calibration ........

Line Position and Line Shape Standard for

Powder Diffraction (Lanthanum Hexaboride Powder)... 80
SRM

663

665

670

$674 \mathrm{~b}$

675

$676 a$

679

682

683

$685 \mathrm{r}$

688

689

690

691

692

693

694

695

696

697

698

699

$705 a$

$706 \mathrm{a}$

709

$717 \mathrm{a}$

720

$723 \mathrm{e}$

728

731L1

$731 \mathrm{~L} 2$

$731 \mathrm{~L} 3$

$740 \mathrm{a}$

$741 \mathrm{a}$

742

762

$764 \mathrm{a}$

$772 \mathrm{a}$

781D2

$853 \mathrm{a}$

$854 \mathrm{a}$

$855 \mathrm{a}$

$856 \mathrm{a}$

858

861

862

864

865

866

867

868

$869 b$

870

871

872

874

875

880

882
Descriptor

Page \#

Chromium-Vanadium Steel (Modified) ............................... 3

Electrolytic Iron ..................................................................... 3

Rutile Ore (....................................................................... 46

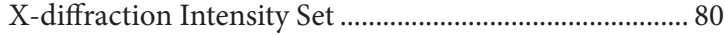

Line Position, Mica (XRD) ................................................. 80

Alumina Powder for Quantitative Analysis

by X-ray Diffraction ................................................................ 80

Brick Clay........................................................................ 46

High-Purity Zinc.................................................................. 14

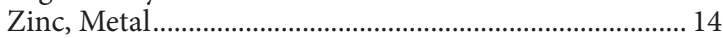

High Purity Gold (rod) ....................................................... 14

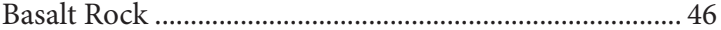

Ferrochromium Silicon........................................................ 4

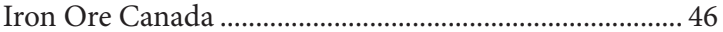

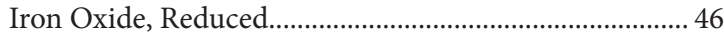

Iron Ore, Labrador................................................................. 46

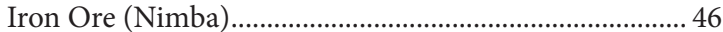

Phosphate Rock, Western ............................................ 43,46

Trace Elements in Multi-Nutrient Fertilizer .................... 43

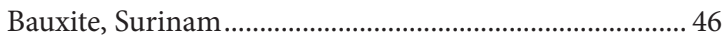

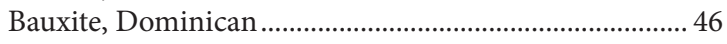

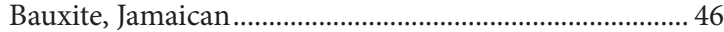

Alumina (Reduction Grade) ............................................ 46

Polystyrene

(Narrow Molecular Weight Distribution) ...............60, 62

Polystyrene (Broad Molecular Mass Distribution).......... 60

Extra Dense Lead Glass....................................................... 78

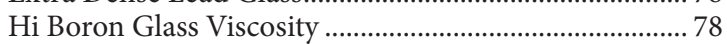

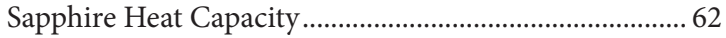

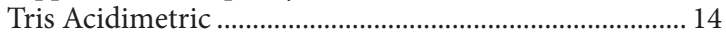

Intermediate-Purity Zinc (pin) ......................................... 14

Borosilicate Glass - Thermal Expansion ............................ 63

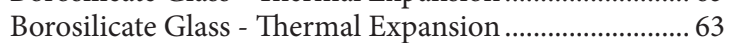

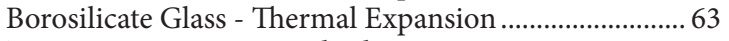

Zinc Freezing Point Standard $419.527^{\circ} \mathrm{C}$............................. 62

Tin Freezing-Point Standard .............................................. 62

Aluminum Oxide Pyrometric Standard ............................ 63

Magnetic Moment Standard - Nickel Disk....................... 94

Magnetic Susceptibility Standard - Platinum Cylinder . 94

Magnetic Moment Standard - Nickel Sphere ................... 94

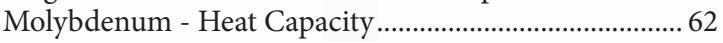

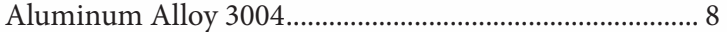

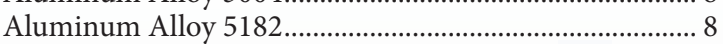

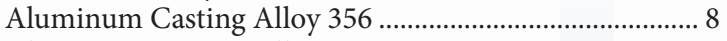

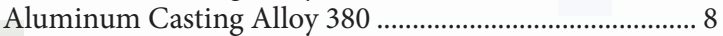

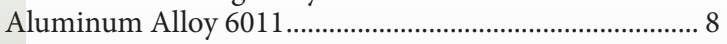

Nickel-based Superalloy PWA 1484 (chip form).............. 9

High-Temperature Alloy L 605 ....................................... 3,8

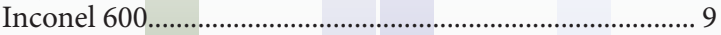

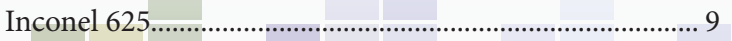

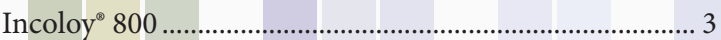

Ni-Fe-Cr Alloy UNS N08825 (chip form).......................... 3

High-Temperature Alloy (Fe-Ni-Co) .................................. 3

Column Selectivity Test Mixture

for Liquid Chromatography ...

Column Performance Test Mixture

for Liquid Chromatography ............................................ 38

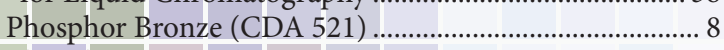

Phosphor Bronze (CDA 544) .............................................. 8

Cupro-Nickel, 10 \% (CDA 706) "HIGH-PURITY" ......... 8

Cupro-76t5Nickel, 10 \% (CDA 706) "DOPED".................. 8

Nickel Silver (CDA 770) .................................................... 8

Nickel-Copper Alloy $(65 \mathrm{Ni}-31 \mathrm{Cu}-3 \mathrm{Al})$............................. 9 
SRM

885

886

887

888

889

892

893

895

897

899

$900 \mathrm{a}$

909 c

911c

$912 \mathrm{a}$

$913 \mathrm{~b}$

914a

$915 b$

$916 \mathrm{a}$

$917 \mathrm{c}$

$918 \mathrm{c}$

$919 \mathrm{~b}$
Descriptor

Page \#

Refined Copper (pin form).................................................. 14

Refractory Gold Ore ............................................................ 46

Cemented Carbide (W-83,Co-10) ..................................... 50

Cemented Carbide (W-64,Co-25,Ta-5) ............................ 50

Cemented Carbide (W-75,Co-9,Ta-5,Ti-4) ....................... 50

High-Alloy White Cast Iron (Ni-Hard, Type IV).............. 5

Stainless Steel (SAE 405) ......................................................... 4

Stainless Steel (SAE 201) ......................................................... 4

Tracealloy A ………............................................................. 9

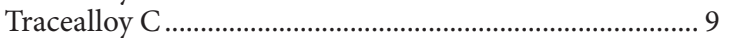

Antiepilepsy Drugs in Frozen Human Serum ................ 20

Frozen Human Serum ................................................20,21

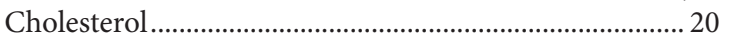

Urea-Clinical ................................................................. 20

Uric Acid ..................................................................... 20

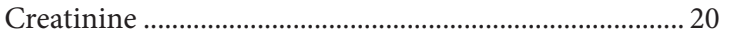

Calcium Carbonate (Clinical Standard) .......................... 20

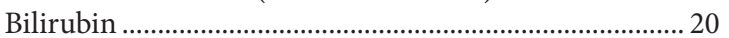

D-Glucose (Dextrose) ............................................... 14,20

Potassium Chloride (Clinical)............................................... 20

Sodium Chloride (Clinical) ............................................. 20

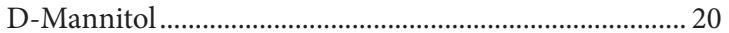

Cortisol (Hydrocortisone) ................................................. 20

Lithium Carbonate ............................................................ 20

Bovine Serum Albumin (7 \%, solution).....................20, 21

Lead Nitrate (Clinical) ....................................................... 20

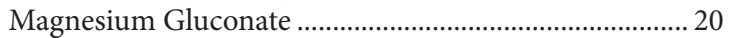

Liquid Absorbance Filters, UV-VIS .................................. 66

Potassium Dichromate (Ultraviolet

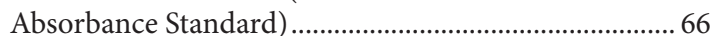

Iron Metal (Clinical Standard) ........................................... 20

Boric Acid Isotopic Standard ............................................ 16

Enriched Boric Acid Standard .......................................... 16

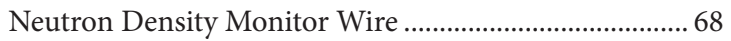

Toxic Metals in Caprine Blood............................................ 20

Electrolytes in Frozen Human Serum .........................20,21

Glucose in Frozen Human Serum .............................. 20,21

Creatinine in Frozen Human Serum............................20,21

Fat-Soluble Vitamins, Carotenoids, and

Cholesterol in Human Serum ....................................20,21

Hormones in Frozen Human Serum.............................20,21

Vitamin D Metabolites in Frozen Human Serum ..... 20,21

Boric Acid Acidimetric Standard................................ 14, 16

Isotopic Standard for Chlorine............................................... 16

Isotopic Standard for Bromine........................................... 16

Assay-Isotopic Standard for Silver..................................... 16

Chromium Isotopic Standard............................................ 16

Isotopic Standard for Magnesium ...................................... 16

Common Lead Isotopic Standard (wire) ........................... 16

Equal-Atom Lead Isotopic Standard (wire) .................... 16

Radiogenic Lead Isotopic Standard (wire) ...................... 16

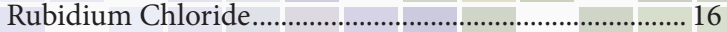

Isotopic Standard for Nickel............................................. 16

Strontium Carbonate Isotopic Standard .......................... 16

Isotopic Standard for Gallium.........................................16

Thallium Isotopic Standard ............................................... 16

Angiotensin I (Human).................................................... 20

Potassium Chloride Primary Standard

(Dried at $500^{\circ} \mathrm{C}$ )

Glass Beads - Particle Size Distribution

Glass Beads - Particle Size Distribution

Microcopy Resolution Test Charts .........

Flooring Radiant Panel..
SRM

Glass Beads - Particle Size Distribution

(100 $\mu \mathrm{m}$ to $400 \mu \mathrm{m}$ diameter range)

Page \#

1018b Glass (Particle Size) ............................................................... 82

1019b Glass (Particle Size) ……………….................................. 82

1021 Glass ( Particle Size) ............................................................. 82

$1034 \quad$ Unalloyed Copper.............................................................. 8

1035 Leaded-Tin Bronze Alloy................................................... 8

1082 Cigarette Ignition Strength Standard (200 cigarettes) ... 88

1083 Wear-Metals in Lubricating Oil ........................................ 54

1085c Wear Metals in Lubricating Oil............................................ 54

$1089 \dagger$ Steels, Set (consists of SRMs 1095, 1096,

1097, 1098 and 1099)

1093 Oxygen in Valve Steel

1094 Oxygen in Maraging Steel....................................................... 5

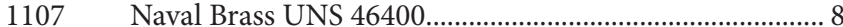

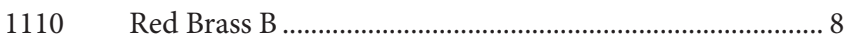

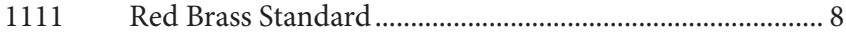

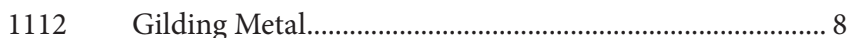

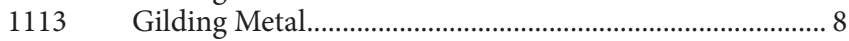

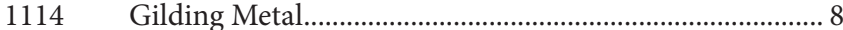

C1114 Gilding Metal C (block) ................................................... 8

1115 Commercial Bronze Standard for Optical

Emission and X-ray Spectroscopic Analysis .................... 8

C1115 Commercial Bronze A (block) .............................................. 8

1116 Commercial Bronze Standard for Optical

Emission and X-ray Spectroscopic Analysis .................... 8

1117 Commercial Bronze Standard for Optical

Emission and X-ray Spectroscopic Analysis ..................... 8

C1117 Commercial Bronze C (block) ............................................. 8

1124 Free Cutting Brass (UNS C36000)..................................... 8

1128 Titanium -Base Alloy (15V-3Al-3Cr-3Sn) ........................ 10

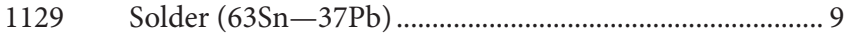

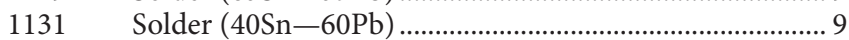

1132 Lead-Base Bearing Metal $(84 \mathrm{~Pb}-10 \mathrm{Sb}-6 \mathrm{Sn})$................... 9

1134 LA Steel, High Silicon........................................................... 3

1135 LA Steel, High Silicon.......................................................... 3

C1137a White Cast Iron ..................................................................... 5

1138a Cast Steel Standard .............................................................. 5

1139a Cast Steel Standard ............................................................ 5

C1145a White Cast Iron.................................................................. 5

C1151a Stainless Steel 23Cr-7Ni ...................................................... 4

C1152a Stainless Steel 18Cr-11Ni .................................................... 4

C1153a Stainless Steel 17Cr-9Ni ................................................... 4

C1154a Stainless Steel 19Cr-13Ni ......................................................... 4

1155a Stainless Steel (Cr 18 Ni 12, Mo 2) ....................................... 4

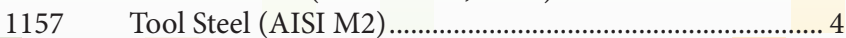

$1158 \quad$ High-Nickel Steel (36 \% Ni) ............................................... 4

1159 Electronic and Magnetic Alloy Standard........................... 9

$1160 \quad$ Elec/Mag Ni-Mo-Fe......................................................... 9

1171 Stainless Steel Cr 17-Ni 11-Ti 0.3 (AISI 321) ...................... 4

1172 Stainless Steel Cr 17-Ni 11-Nb 0.6 (AISI 348) ...................... 4

1173 Ni-Cr-Mo-V Steel ............................................................. 5

C1173 Cast Steel 3 …................................................................. 5

1196 Standard Cigarette for Ignition

Resistance Testing (400 cigarettes) ..................................... 88
Carbon Modified Silica ........................................................ 27

LA Steel, High Silicon.............................................................. 3

Cr16-Ni2 (AISI 431) ................................................................ 4

Chromium Steel .................................................................. 4

LA Steel, Carbon (AISI 1078)................................................ 3

LA Steel (AISI 4130) ......................................................... 3 
Descriptor

Page \#

LA Steel ........................................................................... 3

LA Steel, Basic Open Hearth, 1 \% C...................................... 3

LA Steel, 0.1 \% C................................................................... 3

High-Temperature Alloy A286 (disk form) ……………... 3

Aluminum Alloy 3004 ............................................................... 8

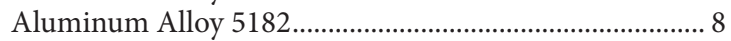

High Temperature Alloy L 605 ............................................. 8

Ni-Cr-Co Alloy UNS N07001 (disk form) .......................... 9

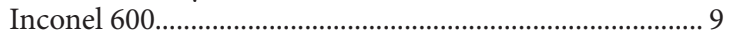

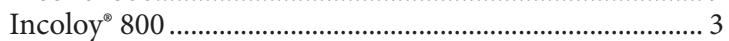

Ni-Fe-Cr Alloy UNS N08825 (disk form) ........................... 3

Nickel-Copper Alloy ............................................................ 9

Ni-Cr-Fe-Nb-Mo Alloy UNS N077178 (disk form) ........ 9

Phosphorus Deoxidized Copper - Cu VIII ........................ 9

Phosphorus Deoxidized Copper - Cu IX............................. 9

Phosphorus Deoxidized Copper - Cu X ............................... 9

High-Temperature Alloy Fe-Ni-Co ..................................... 3

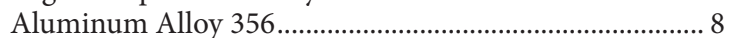

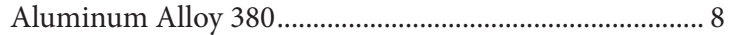

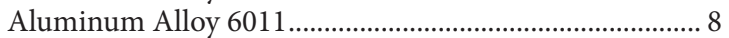

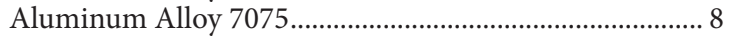

LA Steel, High Carbon (Modified) ........................................ 3

Electrolytic Iron ................................................................. 3

Line Pipe (AISI 1526 Modified) ............................................ 3

LA Steel, Cr-Mo (A336) (F-22) .............................................. 3

LA Steel (HSLA-100) ............................................................. 3

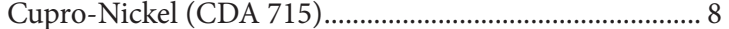

LA Steel (A242) (Modified) ................................................... 3

Low Alloy Steel (HY 80) ......................................................... 3

High-Alloy White Cast Iron (HC-250+V) ......................... 5

High-Alloy White Cast Iron (Ni-Hard, Type I) ................. 5

High-Alloy White Cast Iron I (Ni-Hard, Type IV) ........... 5

Stainless Steel (SAE 405) ....................................................... 4

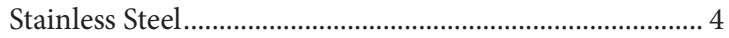

Stainless Steel (SAE 201) ..................................................... 4

Coating Thickness Standard, .............................................. 75

Coating Thickness Standard ............................................. 75

Coating Thickness Standard ................................................. 75

Coating Thickness Standard ............................................... 75

Coating Thickness Standard .............................................. 75

Coating Thickness Standard ............................................ 75

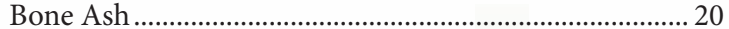

Soft Borosilicate Glass ............................................................ 50

Multicomponent Glass ......................................................... 50

High Alumina Sand ..................................................... 46,50

Aluminosilicate Glass for .................................................... 78

Thermal Resistance - Fumed Silica Board ...........................63 63

Thermal Conductivity, Fibrous Glass Board ...................... 63

Thermal Resistance - Fibrous Glass Blanket

for High Precision Measurements

Thermal Conductivity - Expanded Polystyrene Board.. 63 Superconducting Critical Current - Nb Ti Wire ............ 72 Thermal Resistance - Fumed Silica Board ............................ 63

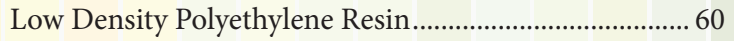

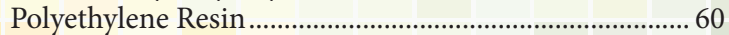

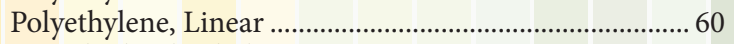

Branched Polyethylene Resin ..............................................6 60

Polystyrene (Narrow Molecular Weight Distribution) .. 60

Polystyrene (Narrow Molecular Weight Distribution) .. 60

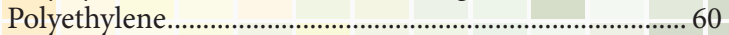

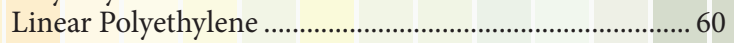

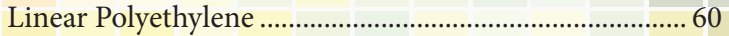

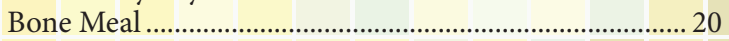

1487

1488

1491a

1492

1493

1494

1496

$1507 \mathrm{~b}$

$1508 \mathrm{a}$

1514

1515

1543

1544

$1546 \mathrm{a}$

1547

$1548 \mathrm{a}$

$1549 a$

$1566 \mathrm{~b}$

$1567 \mathrm{~b}$

$1568 \mathrm{~b}$

$1570 \mathrm{a}$

$1573 a$

$1575 \mathrm{a}$

$1577 \mathrm{c}$

1584

1595

1596

$1597 \mathrm{a}$

$1598 \mathrm{a}$

1599

1614

$1616 \mathrm{~b}$

$1617 \mathrm{~b}$

$1619 \mathrm{~b}$

$1620 \mathrm{c}$

$1622 \mathrm{e}$

$1623 \mathrm{c}$

$1624 \mathrm{~d}$

$1632 \mathrm{~d}$

$1633 \mathrm{c}$

$1634 \mathrm{c}$

$1635 \mathrm{a}$

$1640 \mathrm{a}$

$1641 \mathrm{e}$

$1643 \mathrm{f}$

$1646 \mathrm{a}$

$1647 f$

$1648 \mathrm{a}$

$1649 \mathrm{~b}$

$1650 \mathrm{~b}$

1655

1656

1657

$1658 \mathrm{a}$

1659 a

$1660 \mathrm{a}$
Descriptor

Poly(Methyl Methacrylate)

(6 K Narrow Molecular Weight Distribution)

Page \#

1.............. 60

.................... 60

Methyl-Substituted Polycyclic Aromatic ........................... 38

Chlorinated Pesticides in Hexane ....................................... 38

Polychlorinated Biphenyl Congeners ................................. 38

Aliphatic Hydrocarbons .................................................. 38

Unpigmented Polyethylene Gas Pipe Resin ....................... 60

THC-COOH in Freeze-Dried Urine..............................22,56

Benzoylecgonine (Cocaine Metabolite)

in Freeze-Dried Urine ...

22,56

Thermal Analysis Purity Set.....

62

Apple Leaves ......................................................................... 42

GC/MS System Performance.............................................. 38

Fatty Acids and Cholesterol in a Frozen Diet Composite.. 42

Meat Homogenate .................................................................... 42

Peach Leaves .................................................................. 42

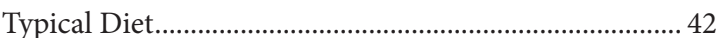

Whole Milk Powder............................................................... 42

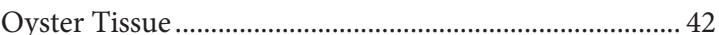

Wheat Flour .......................................................................... 42

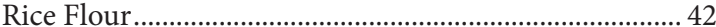

Trace Elements in Spinach Leaves .................................... 42

Tomato Leaves .................................................................. 42

Trace Elements in Pine Needles........................................... 42

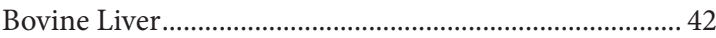

Priority Pollutant Phenols in Methanol ............................ 38

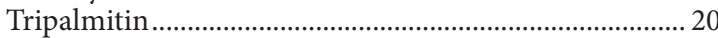

Dinitropyrene Isomers and 1-Nitropyrene

in Methylene Chloride ......................................................... 38

Complex Mixture of Polycyclic Aromatic ...................... 38

Inorganic Constituents in Animal Serum ........................ 20

Anticonvulsant Drug Level Assay Standard....................... 20

Dioxin (2,3,7,8-TCDD in Isooctane) ................................ 38

Sulfur in Kerosene (Low Level).......................................... 34

Sulfur in Kerosine (High Level) ........................................ 34

Sulfur in Residual Fuel Oil (0.7 \%) ...................................... 34

Sulfur in Residual Fuel Oil (4 \%) ........................................ 34

Sulfur in Residual Fuel Oil

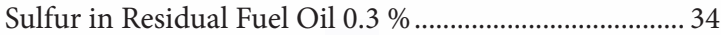

Sulfur in Diesel Fuel Oil, 0.4 \% .............................................. 34

Trace Elements in Coal (Bituminous).....................27,34,35

Trace Elements in Coal Fly Ash ............................................. 35

Trace Elements in Fuel Oil.................................................. 34

Trace Elements in Coal, (Subbitumimous) .................34,35

Trace Elements in Natural Water........................................ 26

Mercury in Water............................................................. 26

Trace Elements in Water .................................................. 26

Estuarine Sediment.....................................................26, 47

Priority Pollutant Polycyclic Aromatic

Hydrocarbons in Acetonitrile

Urban Particulate Matter .........................................22,24,26

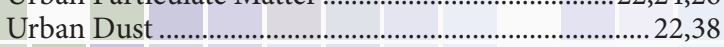

Diesel Particulate Matter..............................................22,38

Potassium Chloride, $\mathrm{KCl}$ (cr) for Solution Calorimetry 62

Thianthrene Combustion Calorimetric Standard ........... 62

Synthetic Refuse-Derived Fuel

Combustion Calorimetric Standard..

Methane in Air (Nominal Amount-of-

Substance Fraction $1 \mathrm{umol} / \mathrm{mol}$ ).

Methane in Air (Nominal Amount-of-

Substance Fraction $10 \mathrm{umol} / \mathrm{mol}$ ) ..

Methane and Propane in Air

(Nominal: $4 \mu \mathrm{mol} / \mathrm{mol}$ Methane; $1 \mu \mathrm{mol} / \mathrm{mol}$ Propane).... 32 
SRM

$1661 \mathrm{a}^{\star}$

$1662 \mathrm{a}^{*}$

$1663 a^{*}$

$1664 \mathrm{a}^{*}$

$1665 b$

$1666 b$

$1667 b$

$1668 b^{*}$

$1669 \mathrm{~b}$

$1674 b^{*}$

$1677 c^{*}$

$1678 c^{\star}$

criptor

Sulfur Dioxide in Nitrogen (Nominal Amount-of-

Substance Fraction 500 umol/mol) ................................ 31

Sulfur Dioxide in Nitrogen (Nominal Amount-of-

Substance Fraction $1000 \mu \mathrm{mol} / \mathrm{mol})$................................ 31

Sulfur Dioxide in Nitrogen (Nominal Amount-of-

Substance Fraction $1500 \mu \mathrm{mol} / \mathrm{mol})$.

31

Sulfur Dioxide in Nitrogen (Nominal Amount-of-

Substance Fraction $2500 \mu \mathrm{mol} / \mathrm{mol})$................................. 31

Propane in Air (Nominal Amount-of-

Substance Fraction $3 \mu \mathrm{mol} / \mathrm{mol}$ ).

Propane in Air (Nominal Amount-of-

Substance Fraction $10 \mu \mathrm{mol} / \mathrm{mol})$....

Propane in Air (Nominal Amount-of-

Substance Fraction $50 \mu \mathrm{mol} / \mathrm{mol}) \ldots$

Propane in Air (Nominal Amount-of-

Substance Fraction $100 \mu \mathrm{mol} / \mathrm{mol}$ )

Propane in Air (Nominal Amount-of-

Substance Fraction $500 \mu \mathrm{mol} / \mathrm{mol}$ )

Page \#

31

31

1

Carbon Dioxide in Nitrogen (Nominal Amount-of-

Substance Fraction 7 \% mol/mol)................................... 30

Carbon Monoxide in Nitrogen (Nominal Amount-of-

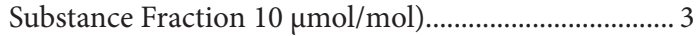

Carbon Monoxide in Nitrogen (Nominal Amount-of-

Substance Fraction $50 \mu \mathrm{mol} / \mathrm{mol})$................................. 31

$1679 c^{*}$ Carbon Monoxide in Nitrogen (Nominal Amount-of-

Substance Fraction $100 \mu \mathrm{mol} / \mathrm{mol})$................................. 31

$1680 b^{*}$ Carbon Monoxide in Nitrogen (Nominal Amount-of-

Substance Fraction $500 \mu \mathrm{mol} / \mathrm{mol})$................................ 31

$1681 b^{*}$ Carbon Monoxide in Nitrogen (Nominal Amount-of-

Substance Fraction $1000 \mu \mathrm{mol} / \mathrm{mol}$ ) ................................. 30

$1683 b^{*}$ Nitric Oxide in Nitrogen (Nominal Amount-of-

Substance Fraction $50 \mu \mathrm{mol} / \mathrm{mol})$.................................... 31

$1684 b^{*}$ Nitric Oxide in Nitrogen (Nominal Amount-of-

Substance Fraction $100 \mu \mathrm{mol} / \mathrm{mol})$................................ 31

$1685 b^{\star} \quad$ Nitric Oxide in Nitrogen (Nominal Amount-of-

Substance Fraction $250 \mu \mathrm{mol} / \mathrm{mol})$................................. 31

$1686 b^{*}$ Nitric Oxide in Nitrogen (Nominal Amount-of-

Substance Fraction 500 mol/mol) ................................. 31

$1687 b^{*}$ Nitric Oxide in Nitrogen (Nominal Amount-of-

Substance Fraction $1000 \mu \mathrm{mol} / \mathrm{mol}$ ) ................................ 31

1689

Sulfur Dioxide in Nitrogen (Nominal Amount-of-

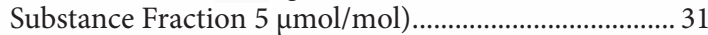

1690 Polystyrene Spheres (1 $\mu \mathrm{m}$ Diameter Particle Size $)$......... 82

1691 Polystyrene Spheres (0.3 $\mu$ m Diameter Particle Size) .... 82

1693a ${ }^{*}$ Sulfur Dioxide in Nitrogen (Nominal Amount-of-

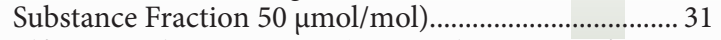

$1694 \mathrm{a}^{*}$ Sulfur Dioxide in Nitrogen (Nominal Amount-of-

Substance Fraction $100 \mu \mathrm{mol} / \mathrm{mol})$................................ 31

$1696 a^{*}$ Sulfur Dioxide in Nitrogen (Nominal Amount-of-

Substance Fraction $3500 \mu \mathrm{mol} / \mathrm{mol}$ )

1710

1711

1713

1718

1720

1721

1727

1728

1729

1738

1739

1740

Zinc-Aluminum Alloy

Zinc-Aluminum Alloy
SRM

1741

1742

1746

1749

1750

1751

1754

1755

$1761 \mathrm{a}$

$1762 \mathrm{a}$

$1763 \mathrm{a}$

$1764 \mathrm{a}$

1765

1766

1767

1768

1772

1775

$1800 \mathrm{~b}$

$1810 \mathrm{a}$

$1818 \mathrm{a}$

$1819 \mathrm{a}$

$1828 b$

1830

1831

1834

1835

$1845 \mathrm{a}$

1848

$1849 \mathrm{a}$

1857

1877

$1878 b$

$1879 b$

$1880 \mathrm{~b}$

$1881 \mathrm{~b}$

$1882 \mathrm{a}$

$1883 a$

$1884 \mathrm{~b}$

$1885 \mathrm{~b}$

$1886 a$

$1886 \mathrm{~b}$

$1887 \mathrm{~b}$

$1888 \mathrm{~b}$

1889 a

1893

$1894 \mathrm{a}$

1895

$1896 \mathrm{~b}$

1898

1900

1905

1906

1907

1908

1909

1917

1921b
Descriptor

Page \#

Zinc-Aluminum Alloy ........................................................ 10

Zinc-Aluminum Alloy ............................................................ 10

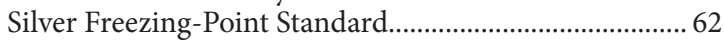

Gold versus Platinum Thermocouple

Certified Thermometer

Thermometer Certified Thermometer

Standard Platinum Resistance

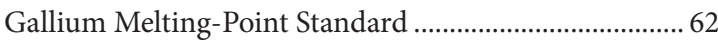

Low-Alloy Steel, AISI 4320 .................................................... 5

Nitrogen in Low Alloy Steel.................................................... 5

Low Alloy Steel.......................................................................... 3

Low Alloy Steel .................................................................. 3

Low Alloy Steel................................................................ 3

Low Alloy Steel........................................................................ 3

Low Alloy Steel................................................................... 3

Low Alloy Steel........................................................................ 3

Low Alloy Steel.................................................................... 3

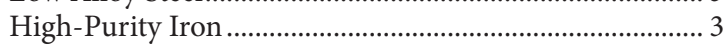

Tool Steel (S-7) .................................................................... 4

Refractory Alloy MP-35-N ................................................. 8,9

Eighteen Non-Methane Hydrocarbon Compounds

in Nitrogen (Nominal $5 \mathrm{nmol} / \mathrm{mol}$ ) ................................ 32

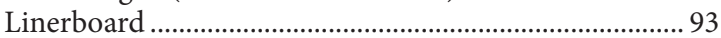

Chlorine in Lubricating Base Oils .................................... 54

Sulfur in Lubricating Base Oil.......................................... 54

Ethanol-Water Solutions (Nominal Mass Fractions

of $0.02 \%, 0.04 \%, 0.08 \%, 0.1 \%, 0.2 \%$, and $0.3 \%$, )..21,56

Soda Lime Float Glass ......................................................... 50

Soda Lime Sheet Glass........................................................... 50

Fused Simulated Ore for X-ray

Borate Ore...

Whole Egg Powder ............................................................. 42

Lubricating Oil Additive Package ........................................ 54

Infant/Adult Nutritional Formula ...................................... 42

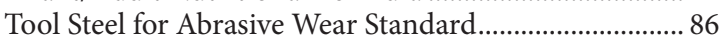

Beryllium Oxide Powder .................................................. 22

Respirable Alpha Quartz

(Quantitative X-Ray Powder Diffraction Standard)..22,80

Respirable Cristobalite ................................................. 22,80

Portland Cement.................................................................. 52

Portland Cement (Blended with Fly Ash) ........................ 52

Calcium Aluminate Cement................................................. 52

Calcium Aluminate Cement.................................................. 52

Portland Cement................................................................. 52

Portland Cement ................................................................ 52

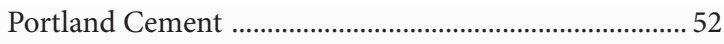

Portland Cement .................................................................. 52

Portland Cement ................................................................. 52

Portland Cement .................................................................... 52

Portland Cement (Blended with Limestone) ................... 52

Copper Microhardness Test Block (Knoop) .................... 86

Vickers Microhardness of Copper ........................................ 86

Nickel Microhardness Test Block (Knoop) ........................ 86

Vickers Microhardness of Nickel ........................................ 86

Titanium Dioxide Nanomaterial .................................... 83,90

Specific Surface Area Standard ......................................... 83

Nickel Microhardness Test Block (Knoop) ....................... 86

Nickel Microhardness Test Block (Knoop) ....................... 86

Nickel Microhardness Test Block (Knoop) ........................ 86

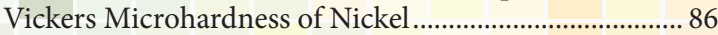

Vickers Microhardness of Nickel ......................................... 86

Mercury Porosimetry Standard .......................................... 83

IR Transmission Wavelength 
SRM

1932

1934

1939a

$1941 b$

1944

1945

1946

1947

1950

$1951 \mathrm{c}$

$1952 \mathrm{a}$

1953

1954

1957

1958

1961

$1963 a$

1964

1965

$1967 \mathrm{a}$

1968

1970

1972

$1974 \mathrm{c}$

1975

$1976 b$

1978

1979

1980

1982

1984

1985

1990

1991

1994

1995

2000

2012

$2031 b$

2034

2035a

2036

2061

2062

2066

2073a
Descriptor

66

Fluorescein Solution .....

66

Cytometry (Visible Spectral Range)...

Polychlorinated Biphenyls (Congeners)

Organics in Marine Sediment .............................................. 38

New York/New Jersey Waterway Sediment......26,27,38,47

Organics in Whale Blubber ................................................ 38

Lake Superior Fish Tissue ...................................26,38,39,42

Lake Michigan Fish Tissue ................................26,38,39,42

Metabolites in Human Plasma .....................................20,21

Lipids in Frozen Human Serum ..................................20,21

Cholesterol in Human Serum .................................... 20,21

Organic Contaminants in Non-Fortified

Human Milk ................................................................ 38,42

Organic Contaminants in Fortified Human Milk ..... 38,42

Organic Contaminants in Non-Fortified

Human Serum ................................................ 21,38,39

Organic Contaminants in Fortified

Human Serum ...........................................................21,38,39

Polystyrene Spheres $30 \mu \mathrm{m}$ Diameter .................................. 82

Polystyrene Spheres Nominal $100 \mathrm{~nm}$ Diameter ......8 82,90

Polystyrene Spheres Nominal $60 \mathrm{~nm}$ Diameter ........ 82,90

Microsphere Slide (10 $\mu$ m Polystyrene Spheres) ............. 82

High-Purity Platinum Thermoelement

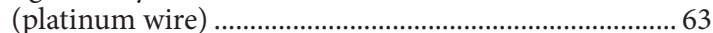

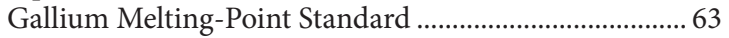

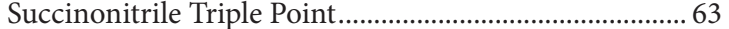

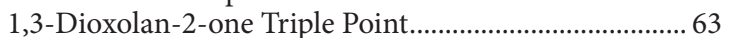

Organics in Mussel Tissue (Mytilus edulis) ...................... 38

Diesel Particulate Extract..............................................22,38

Instrument Response Standard for

X-Ray Powder Diffraction ................................................ 80

Particles Size Distribution Standard

for Gravity Sedimentation ................................................. 82

Powder Diffraction Line Profile Standard

for Crystallite Size Analysis

(Nano-Crystalline ZnO Powder) ...................................... 80

Positive Electrophoretic $(+\mu \mathrm{E})$ Mobility Standard .......... 83

Zirconia Thermal Spray Powder

Particle Size Distribution...

82

Thermal Spray Powder - Particle Size

Thermal Spray Powder - Particle Size Distribution

Tungsten Carbide/Cobalt (Spheroidal)........................... 82

Single Crystal Diffractometer Alignment Standard -

Ruby Sphere ................................................................... 80

Mix Coal Tar/Petroleum Extract ....................................... 38

Standard Silicon Single Crystal Wafer

for Crystalline Orientation

Standard Sapphire Single Crystal Wafer

for Crystalline Orientation ...

Calibration Standard for High-

Resolution X-Ray Diffraction...

Calibration Standard for High-

Resolution X-Ray Diffraction (200 mm Wafer)............ 80

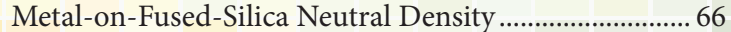

Holmium Oxide Solution Wavelength................................. 66

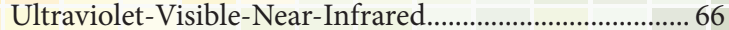

Near Infrared Wavelength/Wavenumber

Reflection Standard

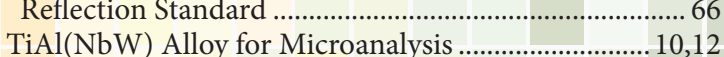

Ti Alloy, Al-Nb-W ........................................................... 10

K-411 Glass Microspheres ................................................ 12

Sinusoidal Roughness Specimen.
SRM

2074

2075

2082

2087

2088

2092

2093

2096

2097

2098

$2100 \mathrm{a}$

$2100 \mathrm{~b}$

2112

2113

2133

2134

$2135 \mathrm{c}$

2137

2139

2141

2143

2144

2152

2159

2160

2165

2166

2167

2168

2171

2172

2175

2181

2182

2185

2186I

2186II

2191a

2192a

2193a

2197

2198

2201

2203

2206

2207

2214
Descriptor

Page \#

Sinusoidal Roughness Specimen......................................... 86

Sinusoidal Roughness Specimen......................................... 86

Pathlength Absorbance Standards for

Microliter Volume Spectrophotometers .......................... 66

Dimensional Standard for Medical

Computed Tomography....

Density Standard for Medical

Computed Tomography...

Low-Energy Charpy V-Notch Impact

Specimens (NIST-Verification, 8-mm Striker) ........... 92

Low-Energy Charpy V-Notch Impact Specimens

(Self-Verification, 8-mm Striker) .................................... 92

High-Energy Charpy V-Notch Impact Specimens

(NIST-Verification, 8-mm Striker) .................................. 92

High-Energy Charpy V-Notch Impact Specimens

(Self-Verification, 8-mm Striker)..

Super High-Energy Charpy V-Notch

Impact Specimen (NIST-Verification) ............................ 92

Fracture Toughness of Ceramic ........................................... 93

Fracture Toughness of Ceramic ........................................... 93

Dynamic Impact Force Verific Specimens

(Nominal 24kN).

Dynamic Impact Force Verification Specimens

(Nominal 33kN) ........................................................ 92

Phosphorus Implant in Si Depth Profile.......................... 74

Profile Standard Arsenic Implant in Silicon Depth ....... 74

Ni/Cr Thin Film Depth Profile............................................ 74

Boron Implant in Silicon Standard

for Calibration of Concentration in a Depth Profile.... 74

Zinc-Alumnum Alloy............................................................ 10

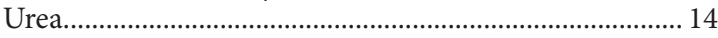

p-Fluorobenzoic Acid........................................................... 14

m-Chlorobenzoic Acid........................................................... 14

Urea Combustion Calorimetric Standard ........................... 62

LA Steel, Carbon \& Sulfur only.......................................... 2

LA Steel, Carbon \& Sulfur only........................................... 2

Low Alloy Steel ………………………………………... 2

Low Alloy Steel.............................................................. 2

Low Alloy Steel......................................................................... 2

High Purity Iron........................................................................ 2

LA Steel, (HSLA 100) ……………………………............. 2

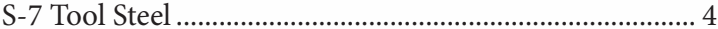

Refractory Alloy MP-35-N .............................................. 8,9

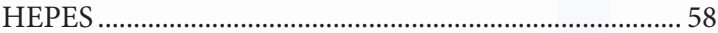

HEPES Sodium Salt .................................................... 58

Potassium Hydrogen Phthalate pD Standard.................... 58

Potassium Dihydrogen Phosphate..................................... 58

Disodium Hydrogen Phosphate........................................ 58

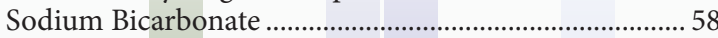

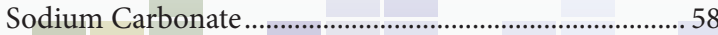

Calcium Carbonate $\mathrm{pH}$ Standard

[used as saturated $\mathrm{Ca}(\mathrm{OH}) 2$ solution] ............................. 58

Low-Energy Charpy V-Notch Specimens

(Self-Verification, 2-mm Striker).

92

High-Energy Charpy V-Notch Specimens

(Self-Verification, 2-mm Striker) ...................................... 92

Sodium Chloride (Ion-Selective) ......................................... 58

Potassium Fluoride (Standard for

Ion-Selective Electrodes) ... 58

Controlled Pore Glass - BET Specific

Surface Area $(300 \mathrm{~nm})$.................................................... 83

Controlled Pore Glass - BET Specific Surface Area......... 83

Isooctane Liquid Density................................................. 78 
SRM

2216

2218

2219

2234

2235

2241

2242

2244

2245

2246

2257

2258

2259

2260a

2261

2262

2266

2269

2270

2273

2274

2275

2294

2295

2296

2297

2298

2299

2366a

2372

2373

2374

2377

2378

$2383 \mathrm{a}$

2384

2385

2387

2389 a

2391c

2392-I

2392

2393

2394

2396

C2400
Descriptor

Miniaturized Low Energy Charpy,

V-Notch KLST Impact Specimen .................................... 92

Miniaturized Hi Energy Charpy,

V-Notch KLST Impact Specimen .................................... 92

Miniaturized Super High Energy, Charpy

V-Notch KLST Impact Specimen ..................................... 92

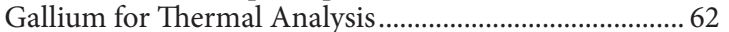

Bismuth for Thermal Analysis ............................................ 62

Relative Intensity Correction Standard

for Raman Spectroscopy: 785 nm Excitation.................. 66

Relative Intensity Correction Standard

for Raman Spectroscopy: $532 \mathrm{~nm}$ Excitation.........................66

Relative Intensity Correction Standard for

Raman Spectroscopy: 1064 nm Excitation .......................... 66

Relative Intensity Correction Standard

for Raman Spectroscopy: 633 nm Excitation........................ 66

Relative Intensity Correction Standard for Raman

Spectroscopy: $830 \mathrm{~nm}$ Excitation................................................ 66

PBDE Congeners in 2,2,4-Trimethylpentane................... 38

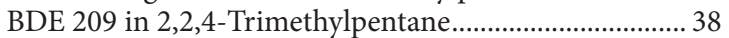

PCB Congeners in 2,2,4-Trimethylpentane .................... 38

Aromatic Hydrocarbon in Toluene ................................... 38

Chlorinated Pesticides in Hexane ........................................ 38

Chlorinated Biphenyl Cogeners ....................................... 38

Hopanes and Steranes in, 2,2,4 Trimethylpentane .......... 38

Perdeuterated PAH-I Solution in Hexane/Toluene ......... 38

Perdeuterated PAH-II Solution in Hexane/Toluene ....... 38

Chlorinated Pesticides (DDTs) and Metabolites

in Isooctane ......................................................................... 38

PCB Congener Solution-II in Isooctane ........................... 38

Chlorinated Pesticide Solution-II in Isooctane ............... 38

Reformulated Gasoline (Nominal Mass

Fraction $11 \%$ MTBE).

Reformulated Gasoline (Nominal Mass

Fraction 15 \% MTBE) ...................................................... 34

Reformulated Gasoline

(Nominal Mass Fraction 13 \% ETBE) ............................. 34

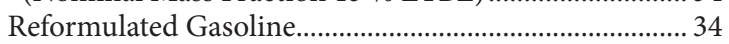

Sulfur in Gasoline (High-Octane) ...................................... 34

Sulfur in Gasoline (Reformulated) ................................... 34

Cytomegalovirus DNA (Towne ${ }_{\triangle 147}$ BAC)

for DNA Measurements ........................................20,23,56

Human DNA Quantitation Standard...........................23,56

Genomic DNA Standards for HER2 Measurements... 23,56

DNA Sequence Library for External RNA Controls . 23,56

Fatty Acid Methyl Esters in, 2,2,4-Trimethylpentane35,38

Fatty Acids in Frozen Human Serum..........................20,21

Baby Food Composite ....................................................... 42

Baking Chocolate .................................................................... 42

Slurried Spinach ........................................................26,42

Peanut Butter ..............................................................26,42

Amino Acids in $0.1 \mathrm{~mol} / \mathrm{L}$ Hydrochloric Acid ................ 20

PCR-Based DNA Profiling Standard............................23,56

Mitochondrial DNA Sequencing

(Human HL-60 DNA)

23,56

.

CAG Repeat Length Mutation

in Huntington's Disease....

Heteroplasmic Mitochondrial DNA

Mutation Detection Standard.

Oxidative DNA Damage Mass

Spectrometry Standards...

High-Alloy Steel ACI (17/4 PH) (disk form)
SRM

C2401

C2402

$\mathrm{C} 2415 \mathrm{a}$

C2416

C2417

C2418

C2424

2426

2429

2430

2431

2432

2433

2445

2448

2451

2452

$2453 \mathrm{a}$

2454

2460

2461

2483

2484

2490

2492

2493

2514

2515

$2517 \mathrm{a}$

$2519 a$

2520

2541

2543

2553

2554

2556

2557

2569

2570

2571

2572

2573

2574

2575

2576

2579 a

2580

2581

2582

2583

2584

2585

2586
Descriptor

Page \#

HA Steel (ACI-C-4M-Cu) .................................................... 3

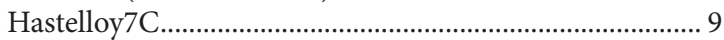

Battery Lead (UNS 52770)................................................. 9

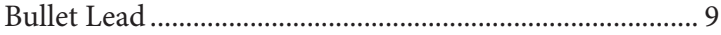

Lead-Base Alloy ..................................................................... 9

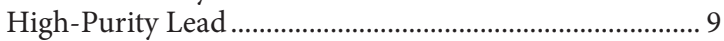

Ductile Iron C......................................................................... 5

55 \% Aluminum-Zinc Alloy............................................. 8, 10

Flue Gas Desulfurization Gypsum ....................35,43,46,52

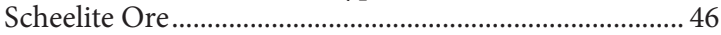

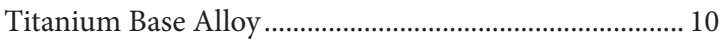

Titanium-Base Alloy 10V-2Fe-3Al.................................. 10

Titanium-Base Alloy 8Al-1Mo-1V ...................................... 10

Mercury in Iodinated Activated Carbon ........................... 27

Mercury in Brominated Activated Carbon ..................... 27

Fine Carbon (Activated) .............................................26,27

Hydrogen In Titanium Alloy.............................................. 10

Hydrogen In Titanium Alloy

(Nominal Mass Fraction 125 mg/kg H)......................... 10

Hydrogen In Titanium Alloy............................................... 10

Standard Bullet .......................................................39,56,94

Standard Cartridge Case ..........................................39,56,94

Single-Wall Carbon Nanotubes (Raw Soot)............... 12,90

Multiwall Carbon Nanotubes (Raw Soot) ........................ 90

Non-Newtonian Polymer Solution.................................... 60

Bingham Paste Mixture for

Rheological Measurements.

Bingham Mortar Mixture for

Rheological Measurements...

Wavelength Calibration Reference

Wavelength Calibration Reference .................................... 74

High Resolution Wavelength Calibration

Reference for 1510 to $1540 \mathrm{~nm}$ Acetylene 12C2H2 ..... 74

High Resolution Wavelength Calibration Reference

for $1530 \mathrm{~nm}-1565 \mathrm{~nm}$ Hydrogen Cyanide....................... 74

Optical Fiber Diameter Standard ..................................... 74

Silicon Resistivity Standard - $0.01 \mathrm{ohm} \bullet \mathrm{cm}$ Level.......... 72

Silicon Resistivity Standard - $1 \mathrm{ohm} \bullet \mathrm{cm}$ Level ................ 72

Optical Fiber Coating Diameter

(Nominal Refractive Index 1.504)...

Optical Fiber Coating Diameter .......................................... 74

Used Auto Catalyst (Pellets) ................................................. 27

Used Auto Catalyst (Monolith) ............................................ 27

Lead Paint Films for Children's Products ......................... 24

Lead Paint Film for Portable X-Ray .................................. 24

Lead Paint Film for Building Surfaces ............................. 24

Lead Paint Film for Building Surfaces ............................. 24

Lead Paint Film for Building Surfaces .............................. 24

Lead Paint Film for Building Surfaces .............................. 24

Lead Paint Film for Building Surfaces ............................. 24

Lead Paint Film for Building Surfaces ............................. 24

Lead Paint Films For Building Surfaces

(SRM 2570 through SRM 2575)...

Powdered Paint Nominal 0.5 \% Lead................................... 24

Powdered Paint Nominal 200 mg/kg Lead...................... 24

Trace Elements in Indoor Dust

(Nominal Mass Fraction of $90 \mathrm{mg} / \mathrm{kg}$ Lead) .......22,24,26

Trace Elements in Indoor Dust

(Nominal Mass Fraction of 90 mg/kg Lead) .......22,24,26

Organic Contaminants in House Dust ..

Trace Elements in Soil Containing Lead

From Paint (Nominal 500 mg/kg Lead)...

...22,38

$.24,26,47$ 
SRM

2587

2589

$2613 \mathrm{a}$

$2614 \mathrm{a}$

2617

$2619 a$

$2620 \mathrm{a}$

$2621 a$

$2622 \mathrm{a}$

$2623 a$

$2624 a$

$2625 a^{*}$

$2627 \mathrm{a}$

$2628 \mathrm{a}$

$2629 \mathrm{a}^{*}$

$2630^{*}$

$2631 a^{*}$

$2635 a^{*}$

$2636 a^{*}$

$2637 \mathrm{a}^{*}$

$2638 a^{*}$

$2639 a$

2640 a

2641a

$2642 a^{*}$

$2644 \mathrm{a}$

$2644 a$

$2646 a$

$2647 a$

$2657 a^{*}$

2658 $\mathrm{a}^{*}$ Oxybstance Fraction $2 \% \mathrm{~mol} / \mathrm{mol}$ ).....................

Substance Fraction $10 \% \mathrm{~mol} / \mathrm{mol}$ ) ...................
Oxygen in Nitrogen (Nominal Amount-of-

Trace Elements in Soil Containing Lead

From Paint (Nominal 3000 mg/kg Lead)............24,26,47

Powdered Paint Nominal 10\% Lead .................................. 24

Carbon Monoxide in Air (Nominal Amount-of-

Substance Fraction $20 \mu \mathrm{mol} / \mathrm{mol})$.................................... 30

Carbon Monoxide in Air (Nominal Amount-of-

Substance Fraction $45 \mu \mathrm{mol} / \mathrm{mol})$.................................... 30

Carbon Dioxide in Nitrogen (Nominal Amount-of-

Substance Fraction $500 \mu \mathrm{mol} / \mathrm{mol})$.................................. 30

Carbon Dioxide in Nitrogen (Nominal Amount-of-

Substance Fraction 0.5 \% mol $/ \mathrm{mol})$................................ 30

Carbon Dioxide in Nitrogen (Nominal Amount-of-

Substance Fraction $1 \% \mathrm{~mol} / \mathrm{mol})$.................................... 30

Carbon Dioxide in Nitrogen (Nominal Amount-of-

Substance Fraction $1.5 \% \mathrm{~mol} / \mathrm{mol}$ ) .................................. 30

Carbon Dioxide in Nitrogen (Nominal Amount-of-

Substance Fraction $2 \% \mathrm{~mol} / \mathrm{mol})$..................................... 30

Carbon Dioxide in Nitrogen (Nominal Amount-of-

Substance Fraction $2.5 \% \mathrm{~mol} / \mathrm{mol}$ ) ................................ 30

Carbon Dioxide in Nitrogen (Nominal Amount-of-

Substance Fraction 3 \% mol $/ \mathrm{mol})$.................................... 30

Carbon Dioxide in Nitrogen (Nominal Amount-of-

Substance Fraction $3.5 \%$ mol$/ \mathrm{mol})$................................ 30

Nitric Oxide in Nitrogen (Nominal Amount-of-

Substance Fraction $5 \mu \mathrm{mol} / \mathrm{mol})$....................................... 31

Nitric Oxide in Nitrogen (Nominal Amount-of-

Substance Fraction $10 \mu \mathrm{mol} / \mathrm{mol})$.................................... 31

Nitric Oxide in Nitrogen (Nominal Amount-of-

Substance Fraction $20 \mu \mathrm{mol} / \mathrm{mol})$.................................... 31

Nitric Oxide in Nitrogen (Nominal Amount-of-

Substance Fraction $1500 \mu \mathrm{mol} / \mathrm{mol})$............................... 31

Nitric Oxide in Nitrogen (Nominal Amount-of-

Substance Fraction $3000 \mu \mathrm{mol} / \mathrm{mol}$ ) ............................... 31

Carbon Monoxide in Nitrogen (Nominal Amount-of-

Substance Fraction $25 \mu \mathrm{mol} / \mathrm{mol})$...................................... 31

Carbon Monoxide in Nitrogen (Nominal Amount-of-

Substance Fraction $250 \mu \mathrm{mol} / \mathrm{mol}$ )

Carbon Monoxide in Nitrogen (Nominal Amount-of-

Substance Fraction $2500 \mu \mathrm{mol} / \mathrm{mol})$.............................. 30

Carbon Monoxide in Nitrogen (Nominal Amount-of-

Substance Fraction $5000 \mu \mathrm{mol} / \mathrm{mol})$............................... 30

Carbon Monoxide in Nitrogen (Nominal Amount-of-

Substance Fraction $1 \% \mathrm{~mol} / \mathrm{mol}$ ).................................... 30

Carbon Monoxide in Nitrogen (Nominal Amount-of-

Substance Fraction $2 \% \mathrm{~mol} / \mathrm{mol}$ ).................................... 30

Carbon Monoxide in Nitrogen (Nominal Amount-of-

Substance Fraction $4 \% \mathrm{~mol} / \mathrm{mol}$ )..................................... 30

Carbon Monoxide in Nitrogen (Nominal Amount-of-

Substance Fraction 8 \% mol $/ \mathrm{mol})$................................... 30

Propane in Nitrogen (Nominal Amount-of-

Substance Fraction $250 \mu \mathrm{mol} / \mathrm{mol})$................................. 32

Propane in Nitrogen (Nominal Amount-of-

Substance Fraction $1000 \mu \mathrm{mol} / \mathrm{mol})$...

Propane in Nitrogen (Nominal Amount-of-

Substance Fraction $2500 \mu \mathrm{mol} / \mathrm{mol}$ )

Oxygen in Nitrogen (Nominal Amount-of-

Substance Fraction $2 \% \mathrm{~mol} / \mathrm{mol}$ )

Substance Fraction $21 \% \mathrm{~mol} / \mathrm{mol}$ )

of-

Total Oxides of Nitrogen (NOx) in Air (Nominal

Amount-of-Substance Fraction $100 \mu \mathrm{mol} / \mathrm{mol}$ )
SRM

2668

2669

$2670 \mathrm{a}$

2681

$2682 c$

$2683 \mathrm{c}$

$2684 \mathrm{c}$

$2685 \mathrm{c}$

$2686 \mathrm{a}$

2687

2688

2689

2690

2691

2693

2695

2696

2700

2701

2702

2703

2709a

2710a

2711a

2716

$2717 a$

$2718 \mathrm{a}$

2719

2720

2721

2722

2723b

2730

2731

2735

2737

2738

$2740 \mathrm{a}$

$2741 \mathrm{a}$

$2745^{*}$

2750

275

2751

2764

2765

2770
Descriptor

Page \#

Toxic Elements in Frozen Human Urine .....................20,21

Arsenic Species in Frozen Human Urine....................20,21

Toxic Elements in Urine (Freeze-Dried) .....................20,21

Trace Constituent Elements in Blank

Filters (47 mm dia)

Subbituminous Coal

(Nominal Mass Fraction 0.5 \% Sulfur) ........................... 34

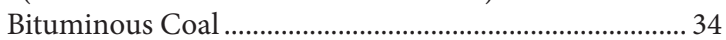

Bituminous Coal ................................................................ 34

Bituminous Coal .............................................................. 34

Portland Cement Clinker...................................................... 52

Portland Cement Clinker................................................... 52

Portland Cement Clinker..................................................... 52

Coal Fly Ash ................................................................ 35,83

Coal Fly Ash ............................................................. 35,83

Coal Fly Ash ........................................................... 35, 33

Bituminous Coal .................................................... 34

Fluoride in Vegetation................................................... 42

Silica Fume........................................................... 50,52,83

Hexavalent Chromium in Contaminated Soil

(Low Level)

26,47

Hexavalent Chromium in Contaminated Soil

(High Level) .............................................................. 26,47

Inorganics in Marine Sediment ...................................26,47

Sediment for Solid Sampling ........................................ 26,47

San Joaquin Soil .......................................................... 26,47

Montana I Soil .......................................................... 26,47

Montana II Soil............................................................ 26,47

Sulfur in Gasoline $(<1 \mathrm{mg} / \mathrm{kg})$........................................... 34

Sulfur in Residual Fuel Oil

(Nominal Mass Fraction 3 \%) ............................................ 34

Green Petroleum Coke...........................................27,34,35

Calcined Petroleum Coke......................................27,34,35

Sulfur in Di-n-Butyl Sulfide ................................................ 34

Crude Oil (Light -Sour) .................................................. 34,35

Crude Oil (Heavy Sweet) ...............................................34,35

Sulfur in Diesel Fuel Oil

(Nominal Mass Fraction $10 \mathrm{mg} / \mathrm{kg}$ ).....

34

Hydrogen Sulfide in Nitrogen (Nominal

Amount-of-Substance Fraction $5 \mu \mathrm{mol} / \mathrm{mol})$................. 32

Hydrogen Sulfide in Nitrogen (Nominal

Amount-of-Substance Fraction $20 \mu \mathrm{mol} / \mathrm{mol}$ ) .............. 32

Nitric Oxide in Nitrogen (Nominal

Amount-of-Substance Fraction $800 \mu \mathrm{mol} / \mathrm{mol}$ ) ............ 31

Nitric Oxide in Nitrogen (Nominal

Amount-of-Substance Fraction $500 \mathrm{nmol} / \mathrm{mol}$ )............ 31

Nitric Oxide in Nitrogen (Nominal

Amount-of-Substance Fraction $1000 \mathrm{nmol} / \mathrm{mol})$.......... 31

Carbon Monoxide in Nitrogen (Nominal

Amount-of-Substance Fraction $10 \% \mathrm{~mol} / \mathrm{mol})$............ 30

Carbon Monoxide in Nitrogen (Nominal

Amount-of-Substance Fraction $13 \% \mathrm{~mol} / \mathrm{mol}$ ) ............ 30

Carbon Dioxide in Nitrogen (Nominal

Amount-of-Substance Fraction $16 \% \mathrm{~mol} / \mathrm{mol}$ ) ............ 30

Methane in Air (Nominal Amount-of-

Substance Fraction $50 \mu \mathrm{mol} / \mathrm{mol})$...................................... 32

Methane in Air (Nominal Amount-of-

Substance Fraction $100 \mu \mathrm{mol} / \mathrm{mol}$ ) .

32

Propane in Air (Nominal Amount-of-Substance

Fraction $0.25 \mu \mathrm{mol} / \mathrm{mol})$

Propane in Air (Nominal Amount-of-

Substance Fraction $100 \mathrm{nmol} / \mathrm{mol}$ ).

Sulfur in Diesel Fuel Oil (40 mg/kg) 


\section{Descriptor}

Page \#

Sulfur in Diesel Fuel Blend Stock ..................................... 34

B100 Biodiesel (Soy-Based) ................................................. 35

B100 Biodiesel (Animal-Based) ...................................... 34,35

Foundry Coke............................................................22,34

Furnace Coke...........................................................2 27,34

Gulf of Mexico Crude Oil ................................................... 38

Hard Rock Mine Waste .................................................. 26,47

Domestic Sludge................................................26,38,39,47

Industrial Sludge ....................................................... 26,47

Air Particulate on Filter Media (47 mm dia) ........22,24,26

Fine Atmospheric Particulate Matter..........................22,38

Fine Atmospheric Particulate Matter ..........................22,38

Vickers Microhardness of Nickel......................................... 86

Medium Test Dust (MTD) in Hydraulic Fluid ................. 83

Rockwell C Hardness - Low Range...................................... 86

Rockwell C Hardness - Mid Range....................................... 86

Rockwell C Scale Hardness - High Range ......................... 86

Rockwell Hardness 15N Scale - Low Range

(Nominal 72 HR15N)...................................................... 86

Rockwell Hardness 15N Scale - Mid Range

(Nominal 83 HR15N) .........................................

Rockwell Hardness 15N Scale - High Range

(Nominal 91 HR15N)........................................................ 86

Rockwell Hardness 30N Scale - Low Range

(Nominal 45 HR30N) .......................................................... 86

Rockwell Hardness 30N Scale - Mid Range

(Nominal 64 HR30N) ..................................................... 86

Rockwell Hardness 30N Scale - High Range

(Nominal 79 HR30N)....................................................... 86

Knoop Microhardness of Steel .......................................... 86

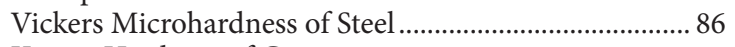

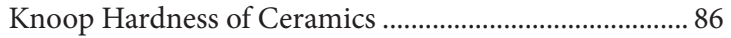

Vickers Hardness of Ceramics and Hardmetals .............. 86

Semiconductor Thin Film: AlxGa1-xAs Epitaxial Layers

(Al mole fraction $\mathrm{x}$ near 0.20) ............................................. 12

Semiconductor Thin Film: AlxGa1-xAs Epitaxial Layers

(Al mole fraction $\mathrm{x}$ near 0.30) ........................................... 12

Relative Permittivity and Loss Tangent

1422 Cross-Linked Polystyrene......................................... 78

Polystyrene Absolute Molecular Mass

Distribution Standard. 60

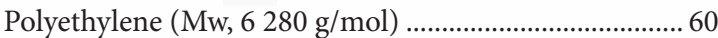

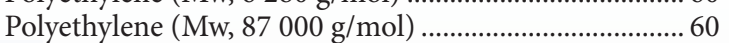

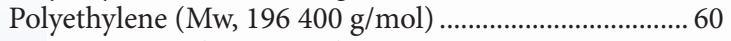

Water Saturated 1-Octanol .................................................... 35

Ethanol-Water Solution

(Nominal Mass Fraction 0.02 \%) ................................21,56

Ethanol-Water Solution

(Nominal Mass Fraction, 0.04 \%) ..............................21,56

Ethanol-Water Solution

(Nominal Mass Fraction, 0.08 \%) ..............................2 21,56

Ethanol-Water Solution

(Nominal Mass Fraction, $0.1 \%$ )

Ethanol-Water Solution

(Nominal Mass Fraction, $0.2 \%$ )

Ethanol-Water Solution

(Nominal Mass Fraction, 0.3 \%) ...............................21,56

Ethanol Water Solution

(Nominal Mass Fraction 2 \%)

Ethanol Water Solution

(Nominal Mass Fraction 6 \%)

Ethanol-Water Solution

(Nominal Mass Fraction 25 \%)
SRM

2900

2905

2907

$2910 \mathrm{~b}$

2921

2924

2940

2941

2942

2943

2944

2950 a

2960

2972a

2973

$2974 a$

2975

2976

3035

3060

3074

3077

3079

3080

$3101 \mathrm{a}$

$3102 \mathrm{a}$

$3103 \mathrm{a}$

$3104 \mathrm{a}$

$3105 \mathrm{a}$

3106

3107

3108

$3109 \mathrm{a}$

3110

$3111 \mathrm{a}$

$3112 \mathrm{a}$

3113

3114

$3115 \mathrm{a}$

$3116 \mathrm{a}$

$3117 \mathrm{a}$

$3118 \mathrm{a}$

$3119 \mathrm{a}$

$3120 \mathrm{a}$

3121

3122

$3123 \mathrm{a}$

$3124 \mathrm{a}$

$3126 \mathrm{a}$

$3127 \mathrm{a}$

3128

$3129 \mathrm{a}$

$3130 \mathrm{a}$

$3131 \mathrm{a}$
Descriptor

Ethanol-Water Solution

(Nominal Mass Fraction 95.6 \%) ................................21,56

Trace Terrorist Explosives Simulants ..........................39,56

Trace Terrorist Explosives Simulants ........................... 39,56

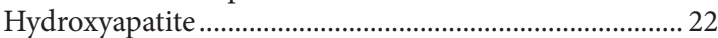

Human Cardiac Troponin Complex .......................... 20,21

C-Reactive Protein Solution ................................................. 20

Relative Intensity Correction Standard for Fluorescence

Spectroscopy: Orange Emission .....................................6 66

Relative Intensity Correction Standard for Fluorescence

Spectroscopy: Green Emission ......................................... 66

Relative Intensity Correction Standard for Fluorescence

Spectroscopy: Ultraviolet Emission.................................. 66

Relative Intensity Correction Standard for Fluorescence

Spectroscopy: Blue Emission ............................................ 66

Relative Intensity Correction Standard for Fluorescence

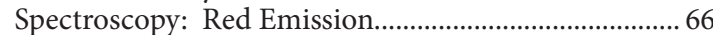

Respirable Alpha Quartz on Filter Media........................ 22

Respirable Cristobalite on Filter Media ............................. 22

25-Hydroxyvitamin D Calibration Solutions.................... 20

Vitamin D Metabolites in Frozen Human Serum

(High Level).....

Organics in Freeze-Dried Mussel Tissue

(Mytilus edulis) ...........................................................22, 22,

Diesel Particulate Matter................................................22, 22,

Mussel Tissue (Trace Elements \& Methylmercury)

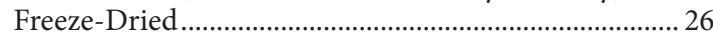

Arsenic Species in Apple Juice ............................................ 42

Monoester Phthalates in Acetonitrile............................... 38

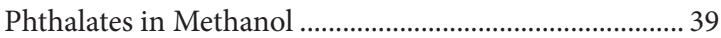

Aroclor 1242 in Transformer Oil....................................... 39

Aroclor 1254 in Transformer Oil....................................... 39

Aroclor 1260 in Transformer Oil......................................... 39

Aluminum (Al) Standard Solution..................................... 15

Antimony (Sb) Standard Solution ..................................... 15

Arsenic (As) Standard Solution ......................................... 15

Barium (Ba) Standard Solution.......................................... 15

Beryllium (Be) Standard Solution .................................... 15

Bismuth (Bi) Standard Solution .......................................... 15

Boron (B) Standard Solution................................................ 15

Cadmium (Cd) Standard Solution ..................................... 15

Calcium (Ca) Standard Solution......................................... 15

Cerium (Ce) Standard Solution ......................................... 15

Cesium (Cs) Standard Solution ............................................ 15

Chromium (Cr) Standard Solution .................................... 15

Cobalt (Co) Standard Solution ............................................ 15

Copper $(\mathrm{Cu})$ Standard Solution ......................................... 15

Dysprosium (Dy) Standard Solution..................................... 15

Erbium (Er) Standard Solution ............................................ 15

Europium (Eu) Standard Solution ...................................... 15

Gadolinium (Gd) Standard Solution................................ 15

Gallium (Ga) Standard Solution ........................................ 15

Germanium (Ge) Standard Solution................................. 15

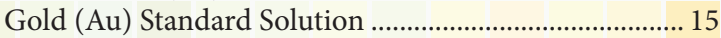

Hafnium (Hf) Standard Solution........................................ 15

Holmium (Ho) Standard Solution...................................... 15

Indium (In) Standard Solution .......................................... 15

Iron $(\mathrm{Fe})$ Standard Solution.................................................. 15

Lanthanum (La) Standard Solution..................................... 15

Lead $(\mathrm{Pb})$ Standard Solution .............................................. 15

Lithium (Li) Standard Solution........................................... 15

Lutetium $(\mathrm{Lu})$ Standard Solution......................................... 15

Magnesium (Mg) Standard Solution................................. 15 
SRM

3132

3133

3134

$3135 a$

3136

3137

3138

3139 a

3140

$3141 \mathrm{a}$

3142 a

3143

3144

$3145 \mathrm{a}$

$3147 \mathrm{a}$

$3148 \mathrm{a}$

3149

3150

3151

$3152 \mathrm{a}$

$3153 a$

3154

3155

3156

$3157 \mathrm{a}$

3158

3159

3160 a

$3161 \mathrm{a}$

$3162 \mathrm{a}$

3163

3164

3165

$3166 \mathrm{a}$

$3167 \mathrm{a}$

3168 a

3169

3177

3180

3181

3182

3183

3184

3185

3186

3222

3233

3234

3235

3236

3237

3238

3239

3246

3247

3248

3250

3251

3252

3254

3255

3256

3257
Descriptor

Page \#

Manganese (Mn) Standard Solution ................................. 15

Mercury (Hg) Standard Solution ......................................... 15

Molybdenum (Mo) Standard Solution.............................. 15

Neodymium (Nd) Standard Solution................................. 15

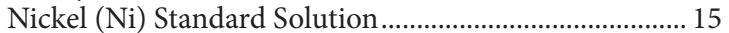

Niobium (Nb) Standard Solution ....................................... 15

Palladium (Pd) Standard Solution ...................................... 15

Phosphorus (P) Standard Solution .................................... 15

Platinum (Pt) Standard Solution ....................................... 15

Potassium (K) Standard Solution ....................................... 15

Praseodymium (Pr) Standard Solution............................... 15

Rhenium (Re) Standard Solution ....................................... 15

Rhodium (Rh) Standard Solution...................................... 15

Rubidium (Rb) Standard Solution..................................... 15

Samarium (Sm) Standard Solution.................................... 15

Scandium (Sc) Standard Solution......................................... 15

Selenium (Se) Standard Solution ......................................... 15

Silicon (Si) Standard Solution .............................................. 15

Silver (Ag) Standard Solution............................................... 15

Sodium (Na) Standard Solution.......................................... 15

Strontium (Sr) Standard Solution ........................................ 15

Sulfur (S) Standard Solution.......................................... 15

Tantalum (Ta) Standard Solution ....................................... 15

Tellurium (Te) Standard Solution ...................................... 15

Terbium (Tb) Standard Solution......................................... 15

Thallium (Tl) Standard Solution........................................... 15

Thorium (Th) Standard Solution ........................................ 15

Thulium (Tm) Standard Solution ......................................... 15

Tin (Sn) Standard Solution................................................ 15

Titanium (Ti) Standard Solution ....................................... 15

Tungsten (W) Standard Solution ......................................... 15

Uranium (U) Standard Solution (Radioactive)................ 15

Vanadium (V) Standard Solution ...................................... 15

Ytterbium (Yb) Standard Solution...................................... 15

Yttrium (Y) Standard Solution............................................ 15

Zinc (Zn) Standard Solution .............................................. 15

Zirconium (Zr) Standard Solution ..................................... 15

Mercuric Chloride Standard Solution................................ 15

Iodide Anion ( $\left.\mathrm{I}^{-}\right)$Standard Solution..................................... 16

Sulfate Anion $\left(\mathrm{SO}_{4}{ }^{2-}\right)$ Standard Solution............................ 16

Chloride Anion $\left(\mathrm{Cl}^{-}\right)$Standard Solution............................... 16

Fluoride Anion (F-) Standard Solution ............................. 16

Bromide Anion ( $\left.\mathrm{Br}^{-}\right)$Standard Solution ........................... 16

Nitrate Anion $\left(\mathrm{NO}_{3}{ }^{-}\right)$Standard Solution .......................... 16

Phosphate Anion $\left(\mathrm{PO}_{4}{ }^{3-}\right)$ Standard Solution ..................... 16

Cigarette Tobacco Filler ....................................................... 43

Fortified Breakfast Cereal .................................................... 42

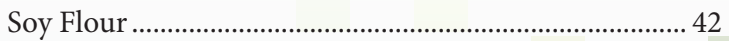

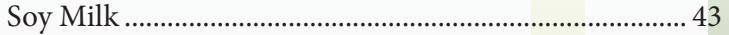

Soy Protein Isolate ............................................................... 43

Soy Protein Concentrate ...................................................... 43

Soy-Containing Solid Oral Dosage Form........................... 43

Isoflavones Calibration Solutions ......................................... 43

Ginkgo biloba (Leaves) ........................................................... 43

Ginkgo biloba (Extract) ......................................................... 43

Ginkgo-Containing Tablets ............................................... 43

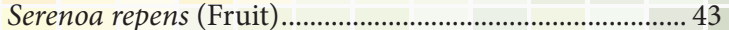

Serenoa repens (Extract)........................................................... 43

Protein Drink Mix ................................................................ 42

Green Tea (Camellia sinensis) Leaves...........................42,43

Green Tea (Camellia sinensis) Extract..........................42,43

Green Tea-Containing Solid Oral Dosage Form ....... 42,43

Catechin Calibration Solutions ..................................... 38,43
3262

3264

3274

3275

3278

3280

3281

3282

3283

3284

3285

3286

3287

3290

3291

3451

3530

3532

3600

3667

3668

3669

3671

3672

3673

3950

$4222 \mathrm{c}$

4226d

$4233 \mathrm{e}$

4239

$4251 \mathrm{C}$

4274

$4288 \mathrm{~b}$

$4320 \mathrm{~b}$

$4321 \mathrm{c}$

$4322 \mathrm{c}$

$4323 \mathrm{~b}$

$4324 \mathrm{~b}$

$4326 \mathrm{a}$

$4328 \mathrm{c}$

4329

$4330 \mathrm{c}$

$4332 \mathrm{e}$

$4334 \mathrm{i}$

4337

$4338 \mathrm{a}$

$4339 \mathrm{~b}$

4340b

4341a

$4342 \mathrm{a}$

$4350 \mathrm{~b}$

4351

4352

$4353 a$
Descriptor

St. John's Wort (Hypericum perforatum L.)

Aerial Parts

Page \#

St. John's Wort (Hypericum perforatum $L$.)

Methanol Extract

38,43

Botanical Oils Containing Omega-3

and Omega-6 Fatty Acids ................................................... 43

Omega-3 and Omega-6 Fatty Acids in Fish Oil.............. 43

Tocopherols in Edible Oils...................................................... 42

Multivitamin/Multielement Tablets .................................... 43

Cranberry (Fruit) ............................................................ 42, 43

Low-Calorie Cranberry Juice Cocktail ......................... 42,43

Cranberry Extract ............................................................... 43

Cranberry-Containing Solid Oral Dosage Form.............. 43

Mixed-Berry Containing Solid Oral Dosage Form......... 43

Organic Acids Calibration Solution .................................. 43

Blueberry (Fruit) .................................................................... 42

Dry Cat Food..................................................................... 42

Bilberry Extract........................................................................ 43

Low Temperature Seebeck Coefficient Standard ............. 63

Iodized Table Salt (Iodide)............................................ 42,43

Calcium-Containing Solid Oral Dosage Form ................ 43

Absolute Intensity Calibration Standard

for Small-Angle X-ray Scattering..................................... 80

Creatinine in Frozen Human Urine .................................. 20

Mercury, Perchlorate, and Iodide

in Frozen Human Urine.

Arsenic Species in Frozen Human Urine

(Elevated Levels) ...........................................................20,21

Nicotine Metabolites in Human Urine (Frozen) ............. 20

Organic Contaminants in Smokers' Urine (Frozen) . 20,38

Organic Contaminants in Non-Smokers' Urine

(Frozen)

Vitamin B6 in Frozen Human Serum ........................20,21

Carbon-14 Radioactivity Standard for

Liquid Scintillation Counting ...

Nickel-63 Radioactivity Standard ....................................... 68

Cesium-137 Radioactivity Standard Solution................... 68

Strontium-90 Radioactivity Standard Solution................. 68

Barium-133 Radioactivity Standard Solution .................... 68

Holmium-166m Gamma-ray Emission Rate

Standard Solution

Technetium-99 Radioactivity Standard ............................. 68

Curium-244 Radioactivity Standard .................................................. 68

Natural Uranium Radioactivity Standard Solution......... 68

Americium-241 Radioactivity Standard .............................. 68

Plutonium-238 Radioactivity Standard ................................... 68

Uranium-232 Radioactivity Standard Solution ............... 68

Polonium-209 Radioactivity Standard.................................68

Thorium-229 Radioactivity Standard Solution................. 68

Curium-243 Radioactivity Standard Solution ................. 68

Plutonium-239 Radioactivity Standard .............................. 68

Americium-243 Radioactivity Standard ............................. 68

Plutonium-242 Radioactivity Standard Solution............. 68

Lead-210 Radioactivity Standard Solution......................... 68

Plutonium-240 Radioactivity Standard Solution.............. 68

Radium-228 Radioactivity Solution ..................................... 68

Plutonium-241 Radioactivity Standard ............................ 68

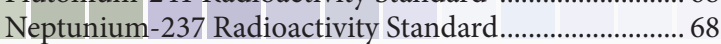

Thorium-230 Radioactivity Standard .................................. 68

River Sediment Environmental Radioactivity Standard.. 70

Human Lung Environmental Radioactivity Standard ... 70

Human Liver Powder ........................................................... 70

Rocky Flats Soil Number 2 
$4401 \mathrm{H}^{* *}$ Iodine-131 Radioactivity Standard ....................................69

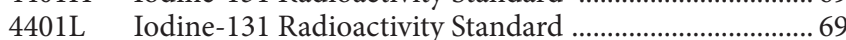

$4404 \mathrm{H}^{* *}$ Thallium-201 Radioactivity Standard ................................ 69

4404L Thallium-201 Radioactivity Standard .................................6 69

$4407 \mathrm{H}^{* *}$ Iodine-125 Radioactivity Standard .................................... 69

4407L Iodine-125 Radioactivity Standard ....................................6 69

$4410 \mathrm{H}$ Technetium-99m Radioactivity Standard ........................69

$4412 \mathrm{H}^{* *}$ Molybdenum-99 Radioactivity Standard …………….......6 69

4412L Molybdenum-99 Radioactivity Standard ..........................6 69

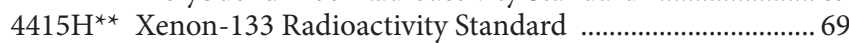

4415L Xenon-133 Radioactivity Standard ……………………......6 69

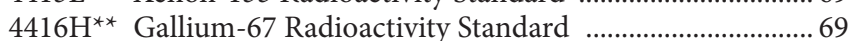

4416L Gallium-67 Radioactivity Standard ..................................... 69

$4417 \mathrm{H}^{* *}$ Indium-111 Radioactivity Standard ................................69 69

4417L Indium-111 Radioactivity Standard ....................................... 69

$4427 \mathrm{H}^{* *}$ Yttrium-90 Radioactivity Standard ...................................6 69

4427L Yttrium-90 Radioactivity Standard ………………............... 69

4915f Cobalt-60 Radioactivity Standard Solution........................ 68

4919i Strontium-90 Radioactivity Standard ...................................... 68

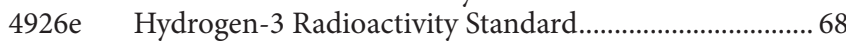

4927f Hydrogen-3 Water Radioactivity Standard .......................6 68

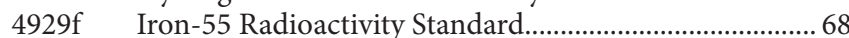

4943 Chlorine-36 Radioactivity Standard ....................................... 68

4949d Iodine-129 Radioactivity Standard Solution.......................6 68

4965 Radium-226 Radioactivity Standard Solution ....................... 68

4966a Radium-226 Radioactivity Standard ....……………….....6 68

4967a Radium-226 Radioactivity Standard Solution .................. 68

4969 Radium-226 Radioactivity Standard ..................................... 68

4990c Oxalic Acid ............................................................ 70

5001 Two-Dimensional Grid Photomask Standard.......................75

$8010 \quad$ Sand for Sand Sieve Analysis................................................ 82

8011 Gold Nanoparticles, Nominal $10 \mathrm{~nm}$ Diameter....22,82,90

8012 Gold Nanoparticles, Nominal $30 \mathrm{~nm}$ Diameter....22,82,90

8013 Gold Nanoparticles, Nominal $60 \mathrm{~nm}$ Diameter....22,82,90

8017 Polyvinylpyrrolidone Coated Silver.................................. 90

8027 Silicon Nanoparticles (Nominal Diameter $2 \mathrm{~nm}$ ) ........... 90

8040 Sodium Oxalate (Na2C2O4) Reductometric Standard ... 14

8091 Scanning Electron Microscope Sharpness Standard...... 74

8095 Sil-xGex Films on Si .................................................... 12

8096 CMOS MEMS 5-in-1 Test Chip......................................... 94

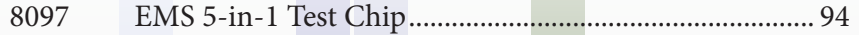

8281 Single-Wall Carbon Nanotubes (Dispersed, ...................90

8321 Peptide Mixture of Proteomics ......................................... 20

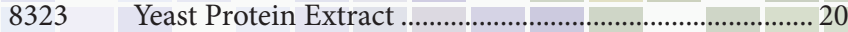

8327 Peptide Reference Material for Molecular

Mass and Purity Measurements....................................... 20

$8375 \begin{aligned} & \text { Microbial Genomic DNA Standards } \\ & \text { for Sequencing Performance Assessment...................23,56 }\end{aligned}$

8391 Human DNA for Whole-Variant Assessment

(Son of Eastern European Ashkenazim

Jewish Ancestry) .....................................................23,56

8392 Human DNA for Whole-Genome Variant Assessment

(Trio of Eastern European Ashkenazim

Jewish Ancestry) ....................................................23,56

8393 Human DNA for Whole-Genome Variant

Assessment (Son of Chinese Ancestry)
SRM

8394

8398

8420

$8441 \mathrm{a}$

8445

8446

8447

8455

8491

8492

8493

8494

8495

8496

8504

8505

$8506 \mathrm{a}$

8509

8510

8529

$8535 a$

8536

8537

8539

8540

8541

8542

8543

8544

8545

8546

8547

8548

8550

8551

8552

8553

8554

8555

8556

8557

8558

8562

8563

8564

8568

8569

8573
Descriptor

Page \#

Tissue Engineering Reference Scaffolds

for Cell Culture...........................................................22, 20

Human DNA for Whole-Genome Variant Assessment

(Daughter of Utah/European Ancestry) ....................23,56

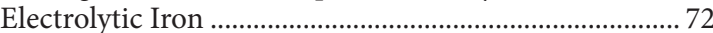

Wheat Hardness ....................................................................... 43

Spray-Dried Whole Egg for Allergen Detection.............. 42

Perfluorinated Carboxylic Acids and

Perfluorooctane Sulfonamide in Methanol ...............38,39

Perfluorinated Sulfonic Acids in Methanol .................. 38,39

Pyrite Ore Bioleaching Substrate ........................................ 46

Sugarcane Bagasse Whole Biomass Feedstock................. 35

Eastern Cottonwood Whole Biomass Feedstock............. 35

Monterey Pine Whole Biomass Feedstock ....................... 35

Wheat Straw Whole Biomass Feedstock........................... 35

Northern Softwood.......................................................35,93

Eucalyptus Hardwood .................................................... 35,93

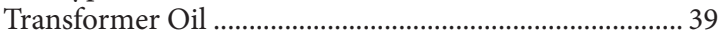

Vanadium in Crude Oil................................................... 34

Moisture in Transformer Oil .............................................. 35

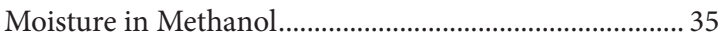

Moisture in Methanol........................................................... 35

IAEA-S-3 (Sulfur Isotopes in Silver Sulfide) ................... 17

VSMOW2 Vienna Standard Mean Ocean Water

(Hydrogen and Oxyen Isotopes in Water)...................... 17

GISP-Water ............................................................................ 17

SLAP-Water Light Stable Isotopic Standard.................... 17

NBS22 Oil (Carbon and Hydrogen Isotopes in Oil) ...... 17

IAEA-CH-7 (Carbon and Hydrogen Isotopes

in Polyethylene Foil) ............................................................. 17

USGS24 Graphite (Carbon Isotopes in Graphite).......... 17

IAEA-CH-6 Sucrose (Carbon Isotopes in Sucrose) ....... 17

NBS 18 (Carbon Isotopes in Carbonatite)........................ 17

NBS 19 Limestone

(Carbon and Oxygen Isotopes in Carbonate) ................ 17

LSVEC (Carbon, Oxygen, and Lithium

Isotopes in Lithium Carbonate)...

NBS28 (Silicon and Oxygen Isotopes in Silica Sand) .... 17

IAEA-N-1 (Nitrogen Isotopes in Ammonium Sulfate) . 17

IAEA-N-2 (Nitrogen Isotopes in Ammonium Sulfate) . 17

USGS25 (Nitrogen Isotopes in Ammonium Sulfate)..... 17

USGS26 (Nitrogen Isotopes in Ammonium Sulfate)..... 17

NSVEC (Nitrogen Isotopes in Gaseous Nitrogen) .......... 17

IAEA-S-4 (Soufre De Lacq) ............................................... 17

IAEA-S-1 (Sulfur Isotopes in Silver Sulfide) ..................... 17

IAEA-S-2 (Sulfur Isotopes in Silver Sulfide) ..................... 17

NBS123 (Sulfur Isotopes in Sphalerite) ………………..... 17

NBS127 (Sulfur and Oxygen Isotopes

in Barium Sulfate).

USGS32 (Nitrogen and Oxygen Isotopes in Nitrate)..... 17

CO2-Heavy, Paleomarine Origin (Carbon Dioxide) ..... 17

CO2-Light, Petrochemical Origin (Carbon Dioxide).... 17

$\mathrm{CO} 2$-Biogenic, Modern Biomass Origin

(Carbon Dioxide).

USGS34 Nitrogen and Oxygen Isotopes in Nitrate........ 17

USGS35 Nitrogen and Oxygen Isotopes in Nitrate......... 17

L-glutamic Acid USGS40(Light Carbon

and Nitrogen Isotopes in L-glutamic Acid)..

L-glutamic Acid USGS41 (Heavy Carbon

and Nitrogen Isotopes in L-glutamic Acid)

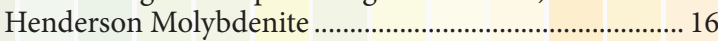

Medium Test Dust (MTD)................................................. 83

Ultra Fine Test Dust (UFTD) ................................................ 83

FDA Saxitoxin Dihydrochloride Solution.... 
Descriptor ............................................................Page \#

8671 NISTmAb, Humanized IgG1к

Monoclonal Antibody ................................................... 20

8680 Paint on Fiberboard, Nominal 1 to $2 \mathrm{mg} / \mathrm{cm} 2$ Lead ...... 24

8704 Buffalo River Sediment ...........................................26,27,47

8785 Air Particulate Matter on Filter Media...................22,26,27

$8786 \quad$ Filter Blank for RM 8785 ........................................22,26,27

8820 Scanning Electron Microscope Scale

Calibration Artifact ................................................74,75

$8850 \quad$ Zeolite Y ................................................................................ 27

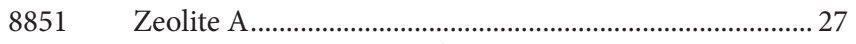

8852 Ammonium ZSM-5 Zeolite................................................ 27

$8983 \quad$ Silicon Nitride .............................................................. 50

8988 Titanium Dioxide Powder - Particle Size Distribution .... 82 



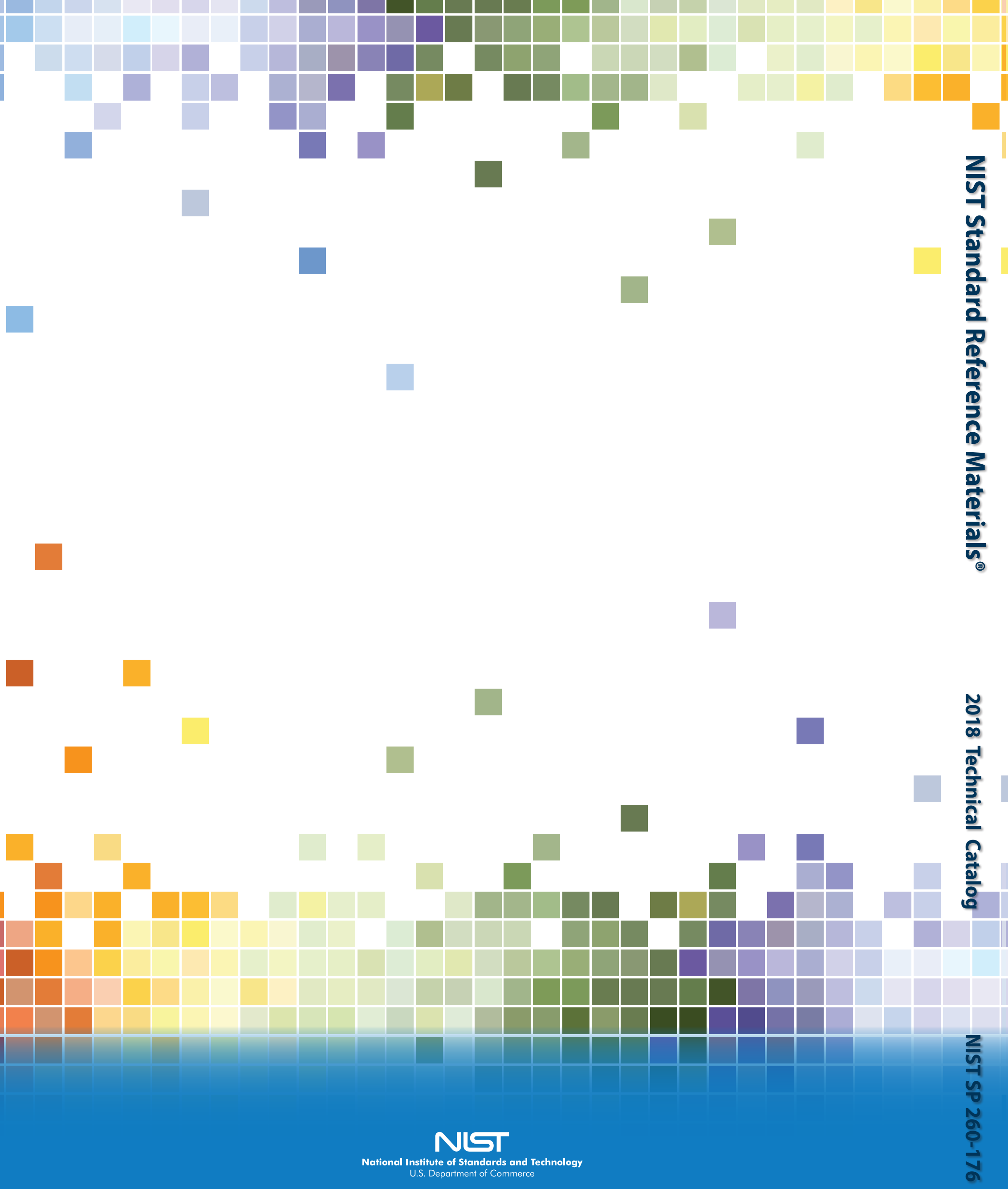

